ANA ISABEL ARROYAVE GUZMÁN

\title{
O TEXTO TREME? \\ INVESTIGAÇÃO SOBRE AS POSSÍVEIS CAUSAS DO ESTRESSE VISUAL OU SÍNDROME DE IRLEN
}

\author{
VERSÃO CORRIGIDA
}




\section{ANA ISABEL ARROYAVE GUZMÁN}

\section{O TEXTO TREME? \\ INVESTIGAÇÃO SOBRE AS POSSÍVEIS CAUSAS DO ESTRESSE VISUAL OU SÍNDROME DE IRLEN}

\section{VERSÃO CORRIGIDA}

Tese apresentada à Escola Politécnica da Universidade de São Paulo para obtenção do Título de Doutor em Ciências. 


\section{ANA ISABEL ARROYAVE GUZMÁN}

\section{O TEXTO TREME? \\ INVESTIGAÇÃO SOBRE AS POSSÍVEIS CAUSAS DO ESTRESSE VISUAL OU SÍNDROME DE IRLEN}

\section{VERSÃO CORRIGIDA}

Tese apresentada à Escola Politécnica da Universidade de São Paulo para obtenção do Título de Doutor em Ciências.

Área de Concentração:

Controle e Automação

Orientador:

Raul Gonzalez Lima 
Autorizo a reprodução e divulgação total ou parcial deste trabalho, por qualquer meio convencional ou eletrônico, para fins de estudo e pesquisa, desde que citada a fonte.

Este exemplar foi revisado e corrigido em relação à versão original, sob responsabilidade única do autor e com a anuência de seu orientador.

São Paulo, 4 de junho de 2020

Assinatura do autor:

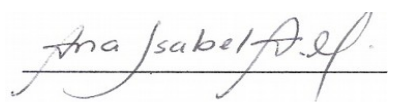

Assinatura do orientador:

\section{Catalogação-na-publicação}

\section{ARROYAVE GUZMÁN, ANA ISABEL}

O texto treme? Investigação sobre as possíveis causas do Estresse Visual ou Síndrome de Irlen / A. I. ARROYAVE GUZMÁN -- versão corr. -- São Paulo, 2020.

$185 \mathrm{p}$.

Tese (Doutorado) - Escola Politécnica da Universidade de São Paulo. Departamento de Engenharia Mecânica.

1.Estresse Visual 2.Síndrome de Irlen 3.Simulação de sistemas 4.Modelos computacionais 5.Processamento visual I.Universidade de São Paulo. Escola Politécnica. Departamento de Engenharia Mecânica II.t. 
Dedicatória

A mi mamá y mi papá 


\section{AGRADECIMENTOS}

Ao meu orientador o Professor Raul Gonzalez Lima, pelas oportunidades, ideias, direcionamentos, compreensão e apoio, refletidos não unicamente neste trabalho, mas na sequência da minha carreira acadêmica e profissional.

Ao doutores Ricardo e Márcia Guimarães pela orientação e ideias para realizar este trabalho.

A toda a equipe de Neurovisão pela oportunidade de discutir sobre o assunto e pelos momentos compartilhados.

À USP, por me propiciar todos os recursos necessários para meu desenvolvimento acadêmico.

À Coordenação de Aperfeiçoamento de Pessoal de Nível Superior (CAPES) pela concessão da bolsa de doutorado para a realização desta pesquisa.

A todo o pessoal do Laboratório de Engenharia Ambiental e Biomédica - LAB da POLI-USP pela amizade e convívio.

A meu amigo Diego Cardona pelas ideias, colaboração, apoio e paciência.

A toda minha família, especialmente aos meus pais, irmãos, sobrinho e cunhada por acreditarem nas minhas capacidades e me motivarem nos momentos difíceis. Sem o apoio da minha família e a meditação não teria conseguido.

A Filipe Fernandes pelo apoio num dos momentos mais difíceis deste processo de doutorado.

Agradeço a Deus: Pai, Filho e Espírito Santo, por abençoar meus dias e sonhos, e pela sustentação física, mental e espiritual ao longo da minha vida. 
"La inspiración existe, pero tiene que encontrarte trabajando"

-- Pablo Picasso 


\section{RESUMO}

O Estresse Visual (EV) ou Síndrome de Irlen (SI) é um distúrbio do processamento visual que principalmente se manifesta como distorções visuais na leitura, fotofobia, dores de cabeça e elevado desconforto ocular. Para tratar esta condição o método de diagnóstico utilizado avalia o nível dos sintomas do paciente e indica filtros espectrais individuais. Atualmente, não se tem um consenso de onde, no sistema visual, estaria a origem da disfunção que provoca o EV. Pesquisas têm proposto hipóteses sobre suas possíveis causas, sem indicar em profundidade quais mecanismos estariam envolvidos na geração dos sintomas e pelas limitações na experimentação em humanos não é possível testar tais hipóteses. Desta forma, neste trabalho foram implementados algoritmos computacionais que descrevem o funcionamento do sistema visual (SV), a partir de modelos matemáticos já formulados, para simular o comportamento de determinada célula o função visual sob diferentes condições, a fim de reproduzir as distorções relatadas no EV e explorar as hipóteses propostas na literatura. Os algoritmos que simularam a interação das células horizontais na retina, o diâmetro pupilar, o controle da posição do olho nas sacadas, a detecção de bordas através do mecanismo de oponência de cor e o efeito de persistência visual, permitiram ilustrar o tipo de distorção que se produz quando nestes sistemas se altera seu correto funcionamento. A partir destes resultados foi possível sugerir que disfunções no processamento visual de baixo nível na retina poderiam gerar uma informação ruidosa, precursora de outros conflitos que estariam afetando, por exemplo, diversas funções do sistema Magnocelular ou do córtex visual. Uma desregulação do neuromodulador dopamina foi sugerida como a precursora da geração de diversos sintomas do EV através da sua função reguladora em outras células da retina. Baseados na investigação sobre as possíveis causas do EV e nos resultados obtidos, foram sugeridos testes que permitiriam conhecer o estado de algumas células e/ou sistemas fisiológicos em pessoas com EV ou SI.

Palavras-Chave - Estresse Visual, Síndrome de Irlen, Filtros Espectrais, Overlays, Retina, Dopamina, Simulação de Sistemas, Modelos Computacionais, Processamento Visual 


\section{ABSTRACT}

Visual Stress (VS) or Irlen Syndrome (IS) is a visual processing disorder that manifests as visual perceptual distortions, photophobia, headaches, and high ocular discomfort. The diagnostic method assesses the patient's level of symptoms and indicates individual spectral filters. Currently, there is no consensus about where is the origin of the dysfunction that generates VS. Several hypotheses have been proposed about the possible causes of VS without indicating which mechanisms would be involved in the generation of symptoms. Due to human test limitations, it is not possible to test such hypotheses. In this work, computational algorithms describing the functioning of the visual system (SV) were implemented from mathematical models previously formulated. This, in order to simulate the behavior of a given cell or visual function under different conditions, to reproduce the EV reported distortions and explore the hypotheses proposed in the literature. Algorithms that simulates retinal cell interaction, pupillary diameter, eye position control in saccades, boundary detection by the color opponency mechanism and the visual persistence effect allowed to illustrate the type of distortions which is generated when the correct performance of the VS is altered. Based on the results, it was possible to suggest that low-level visual processing dysfunctions at the retina could generate noisy information that would be affecting, for example, several functions of the Magnocellular system or the Visual Cortex. Dysregulation of the neuromodulator dopamine has been suggested as the precursor in the generation of the symptoms in EV, through its regulatory function in other retinal cells. Thus, based on the investigation about the possible causes of EV and the obtained results, experiments were suggested that would allow knowing the status of some cells or physiological systems in people with VS or IS.

Keywords - Visual Stress, Irlen Syndrome, Spectral Filters, Overlays, Retina, Dopamine, Systems Simulation, Computational Models, Visual Processing. 


\section{LISTA DE FIGURAS}

Sistema Visual Humano . . . . . . . . . . . . . . . . . . . . . . . . . . . . 27

2 Partes do olho humano f. . . . . . . . . . . . . . . . . 27

3 Principais camadas e células da retina. Quatro camadas de células fazem parte da sua formação. A primeira camada formada pelo epitélio pigmentar funciona como uma proteção. A segunda camada é composta pelas células fotorreceptoras (cones e bastonetes) que recebem a mensagem. A terceira camada é organizada por um conjunto de células (bipolares, horizontais e amácrinas) que transmitem a mensagem captada pelas células receptoras às células nervosas. A quarta camada é constituída pelas células ganglionares, cujos axônios, constituem o nervo óptico que transferem a imagem para o cérebro, onde é decodificada. . . . . . . . . . . . . . . . . . . . . . . . . . . 30

4 Distribuição dos fotorreceptores na retina . . . . . . . . . . . . . . . 31

5 Estrutura dos fotorreceptores da retina . . . . . . . . . . . . . . . . 34

6 Espectro de luz visível que é amostrado por cada tipo de fotorreceptor. Cones S, M, L, Bastonetes (B) e Melanopsina (Mel) . . . . . . . . . . . . . . . . . . . . 35

Distribuição dos fotorreceptores na retina . . . . . . . . . . . . . . . . . . 36

$8 \quad$ Estrutura ON-OFF das células ganglionares . . . . . . . . . . . . . . . . . . 41

9 Curva de Sensibilidade ao contraste (SC) versus Frequência Espacial (FE). . . . . . . 45

10 Centros cerebrais nos quais as ipRGCs projetam suas fibras nervosas e tem-se encontrado implicações clínicas $[115] \ldots \ldots$. . . . . . . . . . . . . . . . . . . . . 49

11 Estrutura célula de Müller . . . . . . . . . . . . . . . . . . . . . 50

12 Caminhos visuais Parvocelular, magnocelular e koniocelular que chegam nas áreas do córtex visual primário e são criados a partir dos axônios das GC Midget, Parasol e K, respectivamente . . . . . . . . . . . . . . . . 53

13 Projeções dos campos visuais direito e esquerdo no LGN. . . . . . . . . . . . . . . . 54 
14 Vias visuais Dorsal e Ventral . . . . . . . . . . . . . . . . . . . . 57

15 Distribuições de frequência da duração da fixação e dos comprimentos da sacada. A duração das fixações está em milisegundos e o comprimento das sacadas esta em número de caracteres. . . . . . . . . . . . . . . . . . . . . . 61

16 Esquema de uma curva de leitura. Adaptado de $[117] \ldots \ldots$. . . . . . . . . . . . 62

17 Esquema do processamento visual em cada fixação . . . . . . . . . . . . . . . . . 63

18 Curva de leitura de uma criança com dificuldade na leitura. [117] . . . . . . . . . . . 63

19 Distorção Halo. As letras ou palavras podem parecer com brilho no fundo ou ter bordas grossas. Podem aparecer também duplicadas . . . . . . . . . . . . . . . 72

20 Distorção Blurry. As letras e/ou palavras no texto podem parecer desfocadas ou difusas

21 Distorção Floating. As palavras no texto podem parecer flutuando, saindo da página ou com um efeito $3 \mathrm{D} \ldots \ldots \ldots \ldots$. . . . . . . . . . . . . . . . . . . 73

22 Distorção Rivers. As letras ou palavras podem juntar-se criando trilhas de espaços em branco parecendo um fluxo na página . . . . . . . . . . . . . . . . . . . . 73

23 Distorção Ripple. As letras ou palavras podem parecer com ondulações em lugar de serem retas e planas . . . . . . . . . . . . . . . . . . 74

24 Distorção Seesaw. As letras ou palavras podem-se mover pela página toda e ficarem embaralhadas e confusas . . . . . . . . . . . . . . . . . . . . . . . 74

25 Distorção Shaky. As letras ou palavras podem parecer que se mexem de lado a lado ou de cima pra baixo . . . . . . . . . . . . . . . . . . . . . 75

26 Distorção Swirl. As letras ou palavras podem parecer que se mexem como num redemoinho deixando só o foco estático . . . . . . . . . . . . . . . . . 75

27 Distorção Starwars. As linhas do texto podem parecer em perspectiva com um efeito túnel onde algumas linhas podem parecer mais longe e outras mais perto . . . . . . . 76

28 Distorção Washout. O texto pode parecer com partes lavadas ou ficar difuso por partes 76

29 Overlays e lentes coloridos . . . . . . . . . . . . . . . . . . . 76 
30 Cromaticidades das 9 cores das overlays (círculos brancos) e a overlay cinza (ponto central) quando são sobrepostas numa página branca. As cromaticidades das overlays duplas da mesma cor são os círculos cinza externos, e as cruzes representam as overlays duplas com a cor vizinha . . . . . . . . . . . . . . . . . . . . . 77

31 Colorímetro intuitivo . . . . . . . . . . . . . . . . . 80

32 Grade número 1 do teste Pattern Glare. $0.3 \mathrm{cpd} \ldots \ldots$. . . . . . . . . . . . 82

33 Grade número 2 do teste Pattern Glare. $2.3 \mathrm{cpd} \ldots$. . . . . . . . . . . . . . . . . 82

34 Grade número 3 do teste Pattern Glare. $9.4 \mathrm{cpd}$. . . . . . . . . . . . . . . . . . . 82

35 Imagem que gera uma ilusão visual de movimento . . . . . . . . . . . . . . . 87

36 Aberração cromática longitudinal (a) e lateral (b) . . . . . . . . . . . . . . . . . 92

37 Pontos brancos no fundo preto vistos com Aberração cromática lateral e longitudinal . 92

38 Esquema de características e funções das ipRGCs . . . . . . . . . . . . . . 106

39 Preferências de cor no estudo de Drew et al. (2012). Os círculos pretos mostram as cromaticidades escolhidas pelos indivíduos com baixo desconforto visual e los círculos brancos dos indivíduos com elevado desconforto visual . . . . . . . . . . . . . . . . 110

40 Diagrama que relaciona os algoritmos desenvolvidos com os sintomas do EV. As elipses amarelas indicam os modelos computacionais desenvolvidos; as roxas, as funções que são alteradas mediante a mudança de parâmetros no algoritmo; as rosas, as células que estão envolvidas nas funções modificadas pelos algoritmos; e as verdes, os sintomas que são simulados a partir dos algoritmos. . . . . . . . . . . . . . . . . . . . . . 115

41 Arquitetura geral do modelo da retina proposto por A. Benoit . . . . . . . . . . . 116

42 Filtro OPL e o gráfico da sua função de transferência . . . . . . . . . . . . . 117

43 Imagem de entrada no algoritmo retina.m. Texto com frequência espacial média (ver

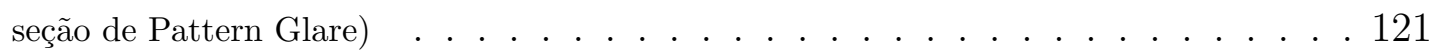

44 Imagem de entrada no algoritmo retina.m. Texto com frequência espacial baixa (ver seção de Pattern Glare 1 . . . . . . . . . . . . . . . . . . . . . . . . . . . 122

45 Curva que descreve a mudança no tamanho da pupila . . . . . . . . . . . . . 123 
46 Imagem de entrada no algoritmo - Paisagem com montanhas sobrepostas . . . . . . . 124

47 Imagem adquirida com o diâmetro e a luminância de referência. . . . . . . . . . . . 124

48 Campos receptivos da células que realizam oponência de cor. . . . . . . . . . . . 126

49 Camadas do modelo de Oponência de cor de Yang. . . . . . . . . . . . . . . . . . . 127

50 O fluxograma resumindo os passos do modelo de Yang. . . . . . . . . . . . . . . . . 129

51 Imagem de entrada no algoritmo - Texto . . . . . . . . . . . . . . 130

52 Sequência de atuação hipotética do sistema transiente e contínuo. Adaptado de [188] . 131

53 Imagem hipotética da imagem vista em várias fixações quando a supressão sacádica é

inibida. . . . . . . . . . . . . . . . . . . . . . 132

54 Imagem entrada no programa que simula a Persistência visual . . . . . . . . . . . 133

55 Planta do modelo de controle sacádico formulado por Robinson . . . . . . . . . . . . 134

56 Tipos de respostas para a posição alvo $\theta_{T}$. Na curva A, o ganho do bloco MLF é normal, na curva B é $17 \%$ maior e na curva $\mathrm{C}$ é $22 \%$ menor. . . . . . . . . . . . . 135

57 Imagem de entrada no algoritmo ctrl_ocular.m . . . . . . . . . . . . . . 136

58 Imagem de entrada vista com a resolução espacial do Sistema visual . . . . . . . . . 136

59 Saída do canal Parvocelular do algoritmo sob parâmetros realistas, (a) sem EV, e (b) com $\mathrm{EV} \ldots \ldots \ldots \ldots$

60 Saída do canal Parvocelular do algoritmo sob parâmetros realistas, (a) sem EV, e (b) com EV. Imagem com frequência espacial baixa. . . . . . . . . . . . . . . . . . 139

61 Respostas do algoritmo pupila.m para a imagem 47 com vários diâmetros na pupila. (a) $2-2.5 \mathrm{~mm},(\mathrm{~b}) 2.5-3 \mathrm{~mm}$, (c) $3-3.5 \mathrm{~mm}$, (d) $3.5-4 \mathrm{~mm}$, (e) $4-4.5 \mathrm{~mm}$ e (f) $4.5-5 \mathrm{~mm} \quad .140$

62 Respostas do algoritmo pupila.m para a imagem de um texto sob vários diâmetros na pupila. (a) $2-2.5 \mathrm{~mm}$, (b) $2.5-3 \mathrm{~mm}$, (c) $3-3.5 \mathrm{~mm}$, (d) $3.5-4 \mathrm{~mm}$, (e) $4-4.5 \mathrm{~mm}$ e (f) 4.5

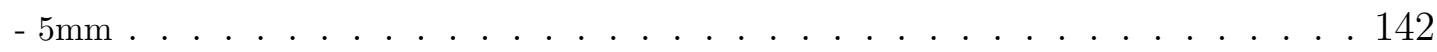


63 Imagens de saída do algoritmo com a figura 46 como imagem de entrada. (a) com $w_{2}$ $=-0.6$ para todos os canais, (b) $w_{2}=-1$ para todos os canais, (c) $w_{2}=-1$ nos canais RG e GR, e (d) com os canais ruidosos filtrados. . . . . . . . . . . . . . . . . . . 143

64 Imagens de saída do algoritmo com a figura 57 como imagem de entrada. (a) com $w_{2}$ $=-0.6$ para todos os canais, (b) $w_{2}=-1$ para todos os canais, (c) $w_{2}=-1$ nos canais RG e GR, e (d) com os canais ruidosos filtrados. . . . . . . . . . . . . . . . . . . . 144

65 Imagem de saída do algoritmo persistencia_visual.m sob parâmetros normais . . . . 145

66 Imagem de saída do algoritmo persistencia_visual.m sob parâmetros que simulam uma disfunção do sistema Magnocelular . . . . . . . . . . . . . . . . . . . . . . . 145

67 Distorção Halo. As letras ou palavras podem parecer com brilho no fundo ou ter bordas grossas. Podem aparecer também duplicadas _ . . . . . . . . . . . . . . . . 146

68 Distorção de sobreposição simulada. Quadro que mostra a distorção criada pela defasagem horizontal na posição de ótima fixação na leitura . . . . . . . . . . . . . . 146

69 Distorção Swirl simulada. Quadro que mostra a distorção criada pela defasagem horizontal/vertical na posição de ótima fixação na leitura . . . . . . . . . . . . . . . 147

70 Distorção Shaky. As letras ou palavras podem parecer que se mexem de lado a lado ou de cima pra baixo . . . . . . . . . . . . . . . . . . . . . 147

71 Distorção Swirl. As letras ou palavras podem parecer que se mexem como num redemoinho deixando só o foco estático . . . . . . . . . . . . . . . . . . . . . 147 


\section{LISTA DE TABELAS}

1 Camadas celulares e sinápticas da retina . . . . . . . . . . . . . . . . . . . 31

2 Parâmetros utilizados no algoritmo retina.m. . . . . . . . . . . . . . . 120

3 Parâmetros utilizados na implementação do modelo de Yang . . . . . . . . . . . . . 130 


\title{
LISTA DE ABREVIATURAS
}

\author{
$\mathrm{AC}$ \\ Amacrine cell(s) - Células amácrinas \\ B \\ Blue - Azul \\ $\mathrm{BC}$ \\ Bipolar cell(s) - Células bipolares \\ BOLD \\ Blood Oxygenation level-dependent \\ $\mathrm{CC}$ \\ Ciclo Circadiano \\ cones-L \\ Cones que absorvem comprimentos de onda Longos (Long) \\ cones-M \\ Cones que absorvem comprimentos de onda Médios (Medium) \\ cones-S \\ Cones que absorvem comprimentos de onda Curtos (Short) \\ DSGC \\ Direction-Selective Retinal Ganglion Cell(s) - Células Ganglionares de \\ Direção Seletiva \\ DZ \\ Dead Zone - Zona Morta \\ ERG \\ Eletrorretinografia \\ G \\ Green - Verde \\ GC \\ Ganglion cell(s) - Células ganglionares \\ GC-M \\ Midget Ganglion cells - Células ganglionares Midget \\ GC \\ Parasol Ganglion cell(s) - Células ganglionares Parasol \\ cpd \\ Cycles per degree \\ dLGN \\ dorsolateral Geniculate Nucleus - Corpo Geniculado dorsolateral \\ EV \\ Estresse Visual \\ ipRGC \\ HCs \\ Intrinsically photosensitive retinal ganglion cell(s) - Células \\ ganglionares intrinsecamente fotosensíveis \\ HUFA \\ Horizontal cells - Células horizontais \\ INL \\ Highly Unsaturated Fatty Acid(s) - Ácido graxos altamente insaturados \\ INHBT \\ Inner Nuclear Layer - Camada nuclear interna \\ IPL \\ Inibição do circuito de cronometragem \\ Inner Plexiform Layer - Camada plexiforme interna
}




\begin{tabular}{|c|c|}
\hline IRPS & Irlen Reading Perceptual Scale \\
\hline \multirow[t]{2}{*}{ ISCEV } & International Society for Clinical Electrophysiology of Vision - \\
\hline & Sociedade Internacional para Eletrofisiologia Clínica da Visão \\
\hline KC & Sistema Koniocelular \\
\hline \multirow[t]{2}{*}{ LCA } & Longitudinal Chromatic Aberration - Aberração Cromática \\
\hline & Longitudinal \\
\hline LGN & Lateral Geniculate Nucleus - Corpo Geniculado Lateral \\
\hline LUM & Sistema de Luminância \\
\hline MLF & Medial Longitudinal Fasciculus - Fascículo Medial Longitudinal \\
\hline MC & Sistema Magnocelular \\
\hline MRI & Magnetic Resonance Imaging - Imagem por Ressonância Magnética \\
\hline NI & Neural Integrator - Integrador Neural \\
\hline ONL & Outer Nuclear Layer - Camada nuclear externa \\
\hline OPL & Outer Plexiform Layer - Camada plexiforme externa \\
\hline OPN & Olivary Pretectal Nucleus - Núcleo Olivar Pré-Tectal \\
\hline PC & Sistema Parvocelular \\
\hline PCT & Edge-light Pupil Cycle Time \\
\hline PG & Pattern Glare \\
\hline PIPR & Post-illumination Pupil Response - Resposta Pupilar pós-iluminação \\
\hline PRVS & Patter Related Visual Stress - Estresse Visual Relacionado à Padrões \\
\hline & listrados \\
\hline $\mathbf{R}$ & Red - Vermelho \\
\hline SI & Síndrome de Irlen \\
\hline SV & Sistema Visual \\
\hline TDAH & Transtorno do Déficit de Atenção com Hiperatividade \\
\hline $\mathbf{R P}$ & Reflexo Pupilar \\
\hline SC & Superior Colliculus - Colículo Superior \\
\hline $\mathrm{SCN}$ & Suprachiasmatic Nucleus - Núcleo Supraquiasmático \\
\hline V1 & Córtex visual primário \\
\hline WRRT & Wilkins Read Rate Test \\
\hline cpd & cycles per degree \\
\hline
\end{tabular}




\section{SUMÁRIO}

Parte I: INTRODUÇÃO 20

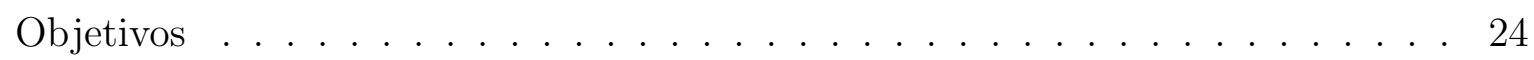

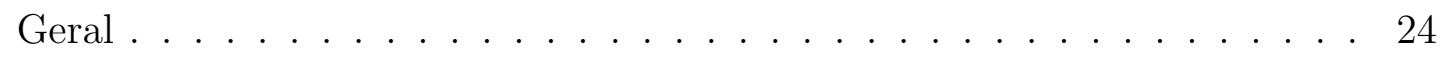

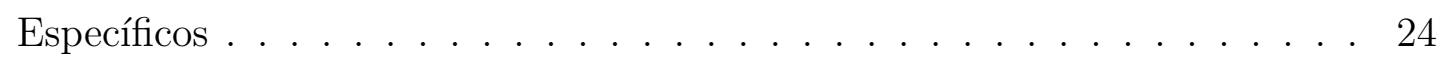

Parte II: REVISÃO BIBLIOGRÁFICA 25

1 Fisiologia da visão $\quad 26$

1.0.1 Recepção . . . . . . . . . . . . . . . . . . . 26

1.0.1.1 Retina .................... 29

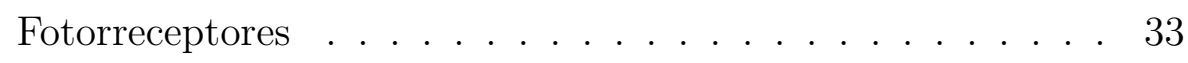

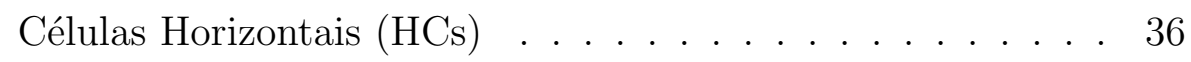

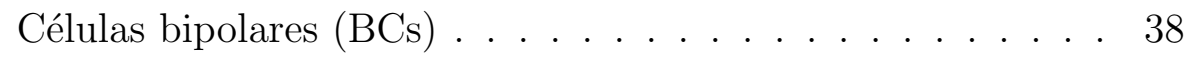

Células amácrinas $(\mathrm{ACs}) \ldots \ldots \ldots$. . . . . . . . . . 38

Células Ganglionares (GCs) . . . . . . . . . . . . . . 39

Células Gliales - Células de Müller . . . . . . . . . . . . 48

1.0 .2 Distribuição . . . . . . . . . . . . . . . . . . . 50

1.0.2.1 Caminhos neuronais visuais . . . . . . . . . . 50

Caminho Magnocelular, Parvocelular e koniocelular . . . . . 51

Corpo Geniculado Lateral (LGN pelo nome em inglês) e

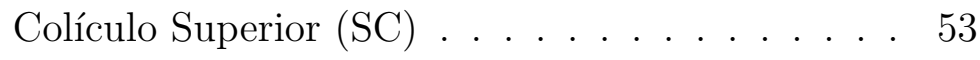


1.0.3 Processamento . . . . . . . . . . . . . . . 55

1.0.3.1 Córtex visual Primário (V1) . . . . . . . . . . 55

1.0.3.2 Vias Dorsal e Ventral . . . . . . . . . . . . 56

2 Movimentos oculares $\quad 59$

2.1 Tipos de movimentos oculares . . . . . . . . . . . . . . . . . . . 59

2.2 Movimentos oculares na leitura . . . . . . . . . . . . . . . 60

2.3 Circuitos neuronais na leitura . . . . . . . . . . . . . . . . . . 64

2.3.1 Persistência visual . . . . . . . . . . . . . . . . . 65

3 Estresse Visual ou Síndrome de Irlen $\quad 67$

3.1 Sintomas . . . . . . . . . . . . . . . . . . . 68

3.1 .1 Dificuldades na leitura . . . . . . . . . . . . . . . . 68

3.1.2 Problemas na escrita . . . . . . . . . . . . . . . . . 69

3.1.3 Desconforto visual . . . . . . . . . . . . . . . . . . . . . . 69

3.1.4 Sensibilidade à luz ou fotofobia . . . . . . . . . . . . . . . . 70

3.1.5 Problemas de atenção e concentração . . . . . . . . . . . . . . . . . 71

3.1.6 Percepção de profundidade diminuída . . . . . . . . . . . . . . . . . 71

3.1.7 Distorções visuais na leitura . . . . . . . . . . . . . . . 71

3.2 Tratamento . . . . . . . . . . . . . . . . . 72

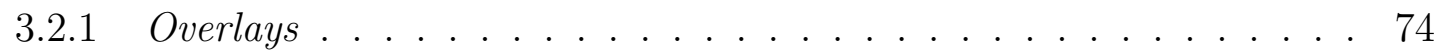

3.2 .2 Lentes . . . . . . . . . . . . . . . . . . . . . . . . . . . 77

3.3 Diagnóstico . . . . . . . . . . . . . . . . . 78

3.3 .1 Método Irlen . . . . . . . . . . . . . . . . . . . . . . . . 79 
3.3.2 Colorímetro intuitivo . . . . . . . . . . . . . . . . . 79

3.3.3 Teste de sensibilidade ao contraste . . . . . . . . . . . . . . 81

3.3.4 Teste de sensibilidade a Padrões Listrados ou Pattern Glare (PG) 81

3.3.5 Sinais para diagnóstico . . . . . . . . . . . . . . 83

3.4 Discussão sobre a definição do Estresse Visual ou Síndrome de Irlen e seu tratamento com filtros espectrais . . . . . . . . . . . . . . . . 84

4 Hipóteses sobre as causas do Estresse Visual e os efeitos dos filtros espectrais

4.1 Hiperexcitabilidade cortical . . . . . . . . . . . . . . . . 86

4.1.1 Por que funcionam os filtros . . . . . . . . . . . . . . . . 88

4.2 Anormalidades do sistema óculo-motor . . . . . . . . . . . . . . . . . 89

4.3 Deficiências do caminho Magnocelular . . . . . . . . . . . . . . . . 95

4.3.1 Filtros espectrais no sistema magnocelular . . . . . . . . . . . . . 97

4.4 Deficiência no sistema koniocelular . . . . . . . . . . . . . . . 100

4.5 Deficiência no processamento de baixo nível, na retina . . . . . . . . . . . 101

4.5.1 Desequilíbrio na informação fornecida pelos cones . . . . . . . . . . 102

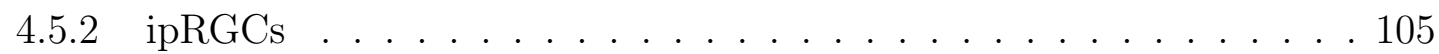

4.6 Cores preferidas . . . . . . . . . . . . . . . . 108

Parte III: METODOLOGIA, RESULTADOS E DISCUSSÃO 113

5 Metodologia

5.1 Modelo da Retina - retina.m . . . . . . . . . . . . . . . . . . 114

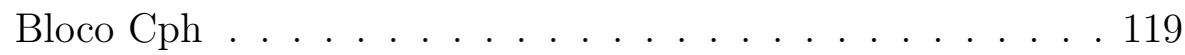


Bloco Fph . . . . . . . . . . . . . . . 119

Bloco Fh ....................... 119

Bloco CgP . . . . . . . . . . . . . . . 120

5.2 Parâmetros . . . . . . . . . . . . . . . . . . . 120

5.2 .1 Imagens de entrada . . . . . . . . . . . . . . . . . . 121

5.3 Modelo da dilatação da pupila - pupila.m . . . . . . . . . . . . . . 122

5.3.1 Imagens de entrada . . . . . . . . . . . . . . . . . . . . 124

5.4 Modelo de detecção de bordas baseado no mecanismo de Oponência de Cor - oponencia_cor.m . . . . . . . . . . . . . . . . 125

5.4 .1 Imagens de entrada . . . . . . . . . . . . . . . . . . 129

5.5 Modelo do fenômeno de Persistência Visual persistencia_visual.m . . . . . . . . . . . . . . . . . 130

5.5.1 Descrição do algoritmo que simula a Persistência Visual . . . . . . . 132

5.5 .2 Imagem de entrada . . . . . . . . . . . . . . 133

5.6 Modelo do Controle Ocular - ctrl_ocular.m . . . . . . . . . . . 133

5.6 .1 Imagem de entrada . . . . . . . . . . . . . . 136

\section{Resultados}

6.1 Modelo da Retina - retina.m . . . . . . . . . . . . . . . 137

6.2 Modelo da dilatação da pupila - pupila.m . . . . . . . . . . . . . 138

6.3 Modelo de detecção de bordas baseado do mecanismo de Oponência de Cor - oponencia_cor.m . . . . . . . . . . . . . . . . . . 141

6.4 Modelo do fenômeno de Persistência Visual persistencia_visual.m . . . . . . . . . . . . . . . 144

6.5 Modelo do Controle Ocular - ctrl_ocular.m . . . . . . . . . . . . . . 145 
7.1 Modelo da Retina - retina.m . . . . . . . . . . . . . . . . . . . . . . 149

7.2 Modelo da dilatação da pupila - pupila.m . . . . . . . . . . . . . . . . . 151

7.3 Modelo de detecção de bordas baseado do mecanismo de Oponência de Cor - oponencia_cor.m . . . . . . . . . . . . . . . . . . . . 151

7.4 Modelo do Controle Ocular - ctrl_ocular.m . . . . . . . . . . . . . . . 155

7.5 Modelo do fenômeno de Persistência Visual persistencia_visual.m . . . . . . . . . . . . . . 156

7.6 Discussão geral . . . . . . . . . . . . . . . . . . . . . 157

Parte IV: PESQUISAS PROPOSTAS E CONCLUSÕES

8 Pesquisas propostas

8.1 Eletrorretinografia $(\mathrm{ERG}) \ldots \ldots \ldots \ldots 16 \ldots \ldots$

8.2 Pupilometria cromática . . . . . . . . . . . . . . . . 163

8.3 Níveis de Dopamina . . . . . . . . . . . . . . . . . . . . . . . . 164

8.4 Conectividade das redes de matéria branca no cérebro . . . . . . . . . . . . 164

8.5 Microsacadas . . . . . . . . . . . . . . . . . . . . . . . . . . . . . . .

9 Conclusões 


\section{PARTE I}

\section{INTRODUÇÃO}


A visão é responsável por grande parte da percepção do entorno. O órgão responsável pela captação do estímulo visual e sua transformação em impulsos elétricos é o olho, onde cada uma das suas estruturas desempenham um papel específico na transformação da informação lumínica. No processamento de baixo nível composto pela retina, algumas estruturas do mesencéfalo e o córtex visual primário é codificada e comprimida a informação adquirida, que será reconstruída pelas demais áreas do córtex visual para criar a percepção visual consciente [107].

No desenvolvimento intelectual dos seres humanos, uma das tarefas mais importantes que realiza o sistema visual (SV) é o processamento de texto ou leitura. Uma decodificação ineficiente da informação visual poderia dificultar a percepção correta do estímulo, e consequentemente, o adequado desenvolvimento e compreensão leitora.

Com frequência é relatado que uma das principais causas do baixo rendimento acadêmico é a dificuldade na leitura [112], a qual pode decorrer de deficiências visuais que obstaculizam o processo leitor. Os problemas na visão podem ter diversas causas, desde refrativos até do córtex cerebral. Um distúrbio no processamento visual que afeta à leitura encontrase presente em 12.5\% das pessoas na etapa escolar e em 31\% da pessoas com Dislexia [111], este e é conhecido como Estresse Visual (EV) no âmbito científico ou Síndrome de Irlen (SI) na área pedagógica. Este distúrbio do processamento visual apresenta sintomas tais como distorções visuais geralmente na leitura, elevada sensibilidade à luz, baixa percepção de profundidade, entre outros; o que produz enxaquecas e um excessivo desconforto e fadiga ocular [92].

O EV é uma alteração na percepção do estímulo visual que não é ocasionada por problemas refrativos ou visuomotores [68], embora possa ter uma correlação com problemas acomodativos e de vergência. Assim, é necessário um diagnóstico diferencial uma vez que não pode ser detectada através de exames oftalmológicos de rotina, nem por testes para a verificação de dificuldades de aprendizagem. Para tratar esta condição o método de diagnóstico utilizado avalia o nível dos sintomas do paciente e indica filtros espectrais individuais na forma de overlays e/ou lentes coloridos, os quais eliminam seletivamente uma parte do espectro de luz visível [92].

Estudos têm mostrado que os filtros coloridos melhoram parâmetros da leitura tais como a velocidade e acurácia, e beneficiam a função óculo-motora ajudando na acomodação e melhorando indicadores tais como número de sacadas, regressões e tempo de fixação [79]. A forma como esta filtragem da luz visível beneficia o correto funcionamento 
do SV não esta bem estabelecida.

No EV não se conhece em qual parte do SV estão sendo gerados os sinais visuais alterados, e em vista disso, várias hipóteses têm sido propostas para explicar sua etiologia. Devido às similaridades nos sintomas visuais do EV e da Dislexia, acredita-se que uma deficiência no sistema magnocelular possa estar relacionado à sua causa $[182,183]$. Adicionalmente, foi formulada a hipótese de uma hiperexcitabilidade cortical para explicar a suscetibilidade dos indivíduos a padrões listrados de alto contraste, como linhas de texto $[216,218]$. Além disso, foi sugerido que os sintomas do EV poderiam ser causados por uma anormalidade ou hipersensibilidade retiniana que gera um sinal ruidoso [172].

Como visto, não existe um concesso sobre a causa do EV e devido à controvérsia que sua definição e validade do tratamento com filtros espectrais ainda gera $[65,70-72,80$, 203,225], atualmente as pesquisas não estão focadas em determinar sua origem. Assim, pesquisas que visem fornecer novas informações que permitam esclarecer os mecanismos por trás da geração dos sintomas do EV irão precisar de um compendio de informações que indiquem o estado atual das pesquisas neste tema e também proporcionem dados sobre a plausibilidade das hipóteses atuais.

Partindo do pressuposto, de que o EV, como ele é descrito, existe; neste trabalho, considerando a descrição das principais hipóteses sobre a causa do EV, procura-se pesquisar e implementar modelos matemáticos que permitam simular o comportamento de certas funções do SV sob diferentes parâmetros. A modelagem computacional permite simular situações em que seria difícil testar ou medir as diversas possibilidades de um fenômeno. Portanto, a partir dos algoritmos computacionais desenvolvidos busca-se ilustrar a saída do processamento de uma imagem sob condições de EV e fisiologicamente corretas.

Por meio dos resultados obtidos seria possível estimar a plausibilidade das hipóteses já propostas e sugerir testes ou experimentos para futuras pesquisas, que ofereçam novas informações para formular a causa do EV.

\section{Organização da tese}

Na parte I estão descritos a Introdução e os Objetivos que visam apresentar e justificar os aspectos que compõem este trabalho.

Para colocar a pesquisa em contexto, a parte II contém uma Revisão Bibliográfica extensiva. No primeiro capítulo, Fisiologia da visão, são descritas as células e sistemas que intervêm no processamento visual de baixo nível na retina, no mesencéfalo e no 
córtex visual primário. Este conhecimento é importante para entender as interações que poderiam acontecer no SV de pessoas com EV. No capítulo 2, devido à relação que existe entre o EV e a leitura, são descritos os principais movimentos oculares acionados na leitura e como eles podem estar sendo afetados no EV. No capítulo 3 é descrita a problemática na qual se enquadra este trabalho, o Estresse Visual ou Síndrome de Irlen; os sintomas, tratamento e diagnóstico são descritos. No capítulo 4, levando em consideração os conhecimentos de fisiologia adquiridos no capítulo 1 e a descrição da condição visual definida no capítulo 3, são apresentadas as principais hipóteses sobre as possíveis causas do EV e sua relação com os filtros espectrais. As teorias da Hiperexcitabilidade Cortical, da deficiência do sistema Magnocelular, da deficiência do sistema Koniocelular e dos Problemas no processamento visual de baixo nível na retina são explicados.

A metodologia, resultados e discussão são apresentadas na parte III. No capítulo 5, são explicados os modelos matemáticos utilizados e os algoritmos computacionais desenvolvidos para simular a interação das células na retina, o diâmetro pupilar, o controle da posição do olho nas sacadas, a detecção de bordas por meio da oponência de cor e o efeito de persistência visual e no capítulo 6 são apresentados os resultados obtidos destas simulações. No capítulo 7 se desenvolve a discussão sobre os resultados obtidos em cada simulação e num nível geral.

Com base na investigação sobre as possíveis causas do EV e nos resultados obtidos, na parte IV são apresentadas sugestões para possíveis experimentos futuros e as conclusões do trabalho. Desta forma, no capítulo 8 são apresentadas algumas propostas de pesquisas que permitiriam conhecer o estado de algumas células e/ou mecanismos em pessoas com EV ou SI para fornecer mais dados que ajudem a esclarecer suas causas. Finalmente, no capítulo 9 são apresentadas as conclusões do trabalho. 


\section{Objetivos}

\section{Geral}

Realizar uma investigação sobre as hipóteses das possíveis causas do distúrbio do processamento visual conhecido como Estresse Visual ou Síndrome de Irlen, para estimar quais delas seriam plausíveis e com isto, direcionar futuras pesquisas na busca da origem ou origens dos sintomas.

\section{Específicos}

- Compilar a informação suficiente para que quem estiver interessado no tema, lendo esta tese, possa adquirir o conhecimento necessário para entender de que se trata esta condição visual, qual é o tratamento atualmente disponível, como se faz o seu diagnóstico, e quais mecanismos estão possivelmente envolvidos na geração dos sintomas.

- Explorar as hipóteses propostas na literatura sobre as prováveis causas do Estresse Visual ou Síndrome de Irlen e o efeito dos filtros espectrais no sistema visual para desenvolver modelos computacionais a fim de aumentar a compreensão do fenômeno e levantar possíveis novas hipóteses.

- Utilizar modelos matemáticos que descrevam algumas funções do sistema visual para desenvolver modelos computacionais que permitam modificar o comportamento de determinada célula ou função visual para reproduzir as distorções relatadas no Estresse Visual.

- Sugerir testes que poderiam ser realizados em pessoas com Estresse Visual, a fim de ampliar a compreensão da causa ou causas deste distúrbio visual. 


\section{PARTE II}

REVISÃO BIBLIOGRÁFICA 


\section{FISIOLOGIA DA VISÃO}

Neste capítulo serão apresentadas algumas definições e conceitos relevantes sobre a anatomia e fisiologia do sistema visual. Esta informação é importante para compreender algumas interações que podem acontecer no sistema visual de pessoas com EV.

O sistema visual humano transforma as ondas eletromagnéticas do espectro visível que chega aos olhos, em sinais nervosos que são interpretados pelo cérebro. Os primeiros passos da percepção visual começam na retina, onde um arranjo de fotorreceptores codifica a intensidade da luz como função da posição $(2 \mathrm{D}$ x,y), o comprimento de onda e o tempo. Na retina, circuitos especializados extraem informações sensoriais básicas, como contraste espacial e frequência temporal da distribuição inicial de intensidade. Toda essa informação é codificada e levada ao cérebro através do nervo óptico. A composição espectral da imagem não é adquirida completamente pelos receptores da retina, no entanto, cálculos realizados no córtex visual conseguem fornecer a informação suficiente para termos as habilidades perceptuais necessárias para o desenvolvimento das tarefas diárias.

Na figura 1 ilustra-se o caminho que deve percorrer uma imagem fótons que são transformados em impulsos elétricos) desde que entra no olho até chegar nas áreas de processamento visual do córtex cerebral. A seguir, serão explicados os processos pelos quais deve passar uma imagem para ser percebida como tal. O sistema visual será dividido em 3 etapas principais: Recepção, distribuição e processamento.

\subsubsection{Recepção}

Na etapa de recepção acontece inicialmente a organização do estímulo luminoso. Ocorre com a refração dos raios luminosos e o processo de focar a imagem na retina. Isto sucede na parte anterior do olho. Depois acontece a Foto-transdução, onde ocorre a transformação dos fótons de luz em sinais nervosos através da atividade fotoquímica. Isto acontece só nos fotorreceptores da retina. E finalmente, a Codificação do sinal visual 


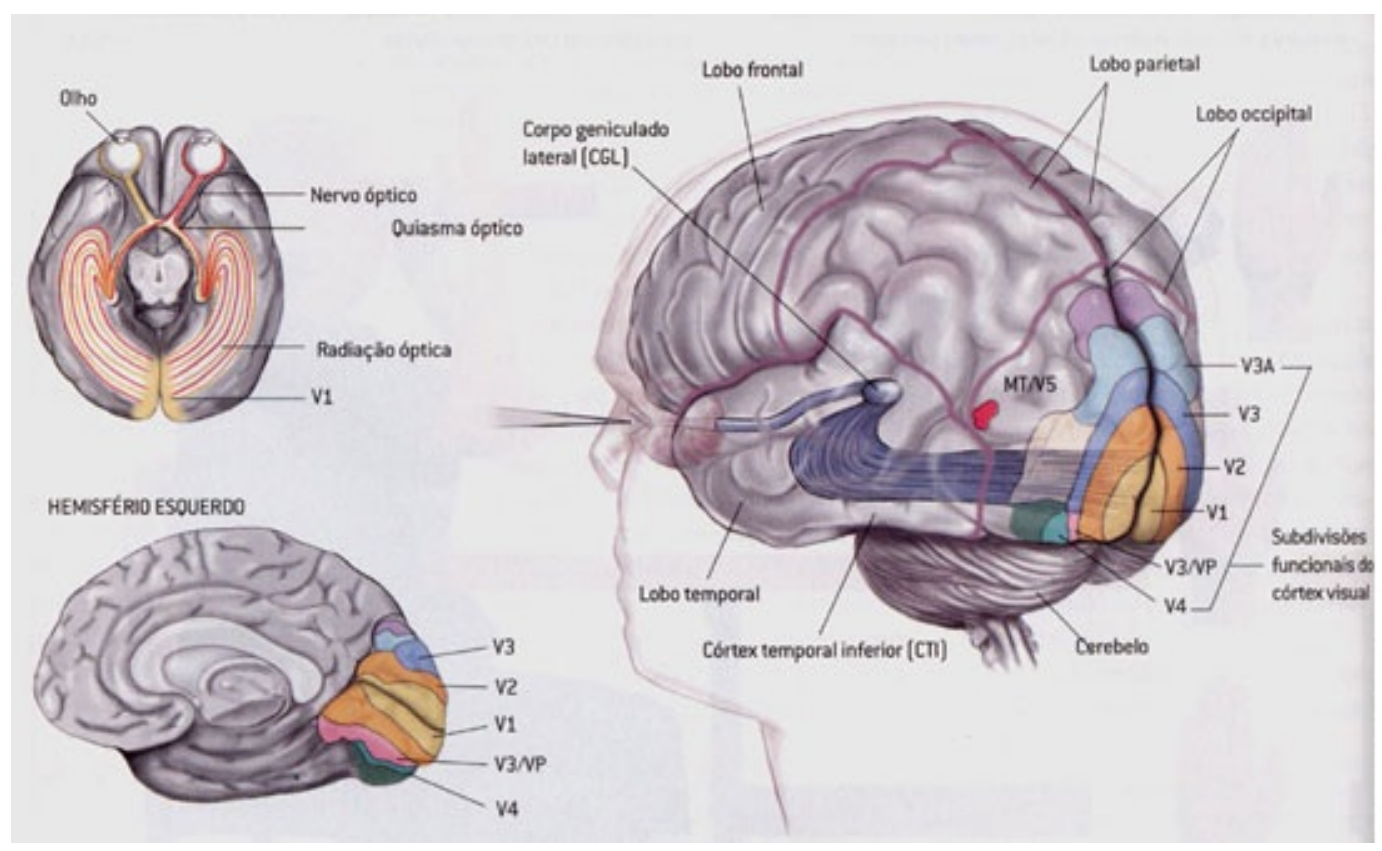

Figura 1: Sistema Visual Humano

Fonte: Adaptado de [10]

na retina, refere-se ao processamento do sinal feito pelas células bipolares e ganglionares (neste processo também interferem as células horizontais e amácrinas), e a seguinte transmissão dessa informação pelo nervo óptico.

A etapa de recepção começa no olho. O olho humano é um instrumento altamente especializado e delicadamente coordenado; cada uma das suas estruturas desempenha um papel específico na transformação da luz nos impulsos elétricos que chegam no cérebro. Possui uma estrutura praticamente esférica onde a luz entra por uma pequena abertura chamada pupila. A coberta externa do olho é fosca e o interior do olho é translúcido. Na figura 2 podem ser observadas suas principais estruturas.
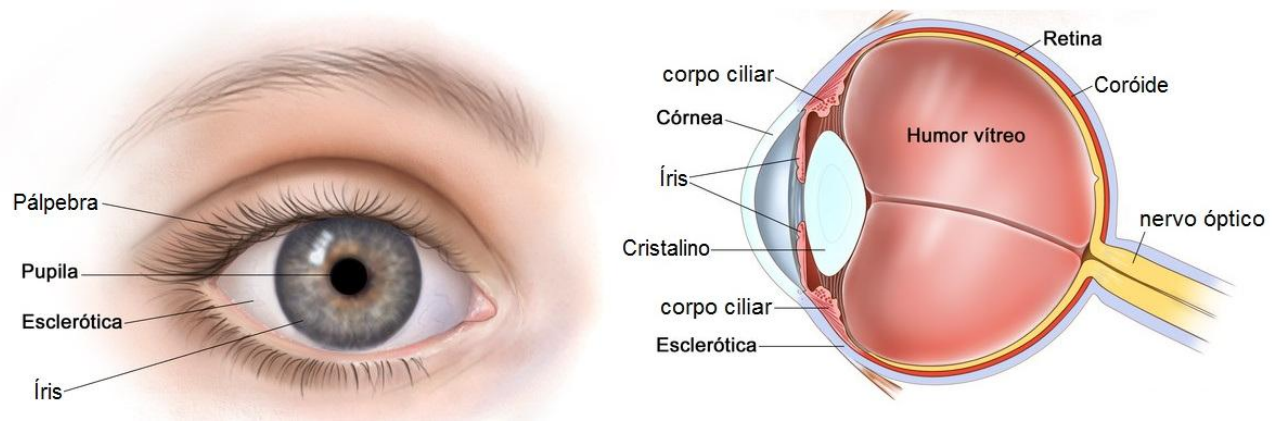

Figura 2: Partes do olho humano

Fonte: Adaptado de [12]

A esclerótica é a membrana mais externa do olho. Ela é opaca, exceto na sua parte 
anterior onde é transparente e passa a chamar-se córnea. Uma das suas principais funções é permitir que a luz entre no olho só pela córnea. Interior à esclerótica encontra-se a coroides, uma membrana muito pigmentada e vascularizada que cobre grande parte do olho; evita que a luz passe através dela e sua abundante irrigação sanguínea proporciona calor e alimento ao resto do olho. A coroides na sua parte anterior possui uma expansão muscular redonda chamada iris em cujo centro existe uma abertura redonda chamada pupila. A função do iris é controlar (mediante um ato reflexo) o diâmetro da pupila, determinando a quantidade de luz que entra no olho. O diâmetro da pupila além de ser modificado pela intensidade da luz, também esta influenciado por um amplo número de processos cerebrais como o ciclo circadiano, a percepção de um estímulo emocional, a detecção de alguma novidade e inclusive alguns processos cognitivos, entre outros [97].

A córnea é a primeira estrutura do olho que é atingida pela luz. A córnea esta constituída por cinco camadas de tecido transparente e resistente. A camada mais externa, o Epitélio, possui boa capacidade regenerativa e se recupera rapidamente de lesões superficiais. As quatro camadas seguintes proporcionam rigidez e protegem o olho de infeções.

No interior do olho encontra-se o humor aquoso, uma dispersão transparente de albumina em água salgada. Este líquido encontra-se na câmara posterior à córnea.

A córnea e o cristalino funcionam como as lentes de um telescópio. Devido ao fenômeno de difração da luz, a córnea concentra a luz externa para que passe através da pupila. O cristalino faz a função inversa, conseguindo a concentração da luz na fóvea (ver seção Retina) e tem a capacidade de, discretamente, aumentar ou diminuir sua superfície curva anterior com o objetivo de ajustar-se às diferentes necessidades de focalização das imagens, próximas ou distantes; esta funcionalidade chama-se Acomodação.

O cristalino tem uma leve pigmentação amarela que absorve a luz infravermelha e ultravioleta, que poderia danificar à retina, e esta formado por estratos concêntricos de células fibrosas que estão unidas ao músculo ciliar. Da tensão deste músculo depende a distancia focal do olho; quando o olho está relaxado, o cristalino fica mais arredondado e o olho foca o infinito.

O olho possui uma câmara contornada pela membrana hialoide e ocupada pelo humor vítreo, uma espécie de gel proteínico muito frágil. Ao passar pelo olho, a luz percorre de forma sucessiva a córnea, o humor aquoso, o cristalino e o humor vítreo até chegar à retina. 
No fundo do olho encontra-se a retina; uma membrana sensível à luz que cobre a totalidade da coroides e não tem mais de $0.5 \mathrm{~mm}$ de espessura. Esta formada basicamente por três camadas de células nervosas interconectadas mediante sinapse. As células ganglionares estão na camada mais externa da retina, enquanto as células fotorreceptoras encontram-se na mais interna. Por causa do arranjo das células, a luz deve passar primeiro através de toda a espessura da retina antes de chegar nos fotorreceptores (cones e bastonetes). No entanto, a luz não passa através nem se reflete no epitélio pigmentoso retinal nem da coroides porque elas são opacas. A retina humana contém 6.5 milhões de cones e 120 milhões de bastonetes. Os bastonetes funcionam principalmente em condições de baixa luminosidade e fornecem informação de luminosidade em escala de cinzas; os cones no entanto, estão adaptados às situações de muita luminosidade e fornecem a informação baseada nos diferentes comprimentos de onda da luz visível.

\subsubsection{Retina}

A retina encarrega-se de receber, modular e transmitir o estímulo visual até o nervo óptico. A luz que bate na retina inicia uma cascata de eventos químicos e elétricos que terminam em impulsos nervosos que são enviados a vários centros visuais do cérebro através das fibras do nervo óptico. A sua superfície exterior esta em contato com a coroide e a superfície interior é adjacente ao humor vítreo.

É possível dividir a retina em duas partes: 1). a retina sensorial, encarregada da foto-transdução da luz pelos fotorreceptores (cones e bastonetes); e 2). a retina neural, que consiste nos típicos interneurônios (células horizontais, bipolares e amácrinas) e nos neurônios de projeção (células ganglionares) que realizam os primeiros passos no processamento da informação visual. Na figura 2 pode ser vista a localização da retina no olho (camada amarela no esquema) e na figura 3 as camadas internas da retina e as principais células que a compõem.

Os diferentes componentes da retina podem ser divididos em camadas (figura 3): a camadas dos segmentos interiores e exteriores dos fotorreceptores (IS/OS, pelo nome em inglês), a membrana limitante externa (ELM), a camada externa nuclear (ONL) que contém os corpos dos fotorreceptores, a camada interna nuclear (INL) que contém os corpos celulares das células horizontais, bipolares, amácrinas e gliais (células de Müller), a camada das células ganglionares (GCL) contém algumas células amácrinas e as células ganglionares. As três camadas nucleares estão separadas por duas camadas sinápticas 


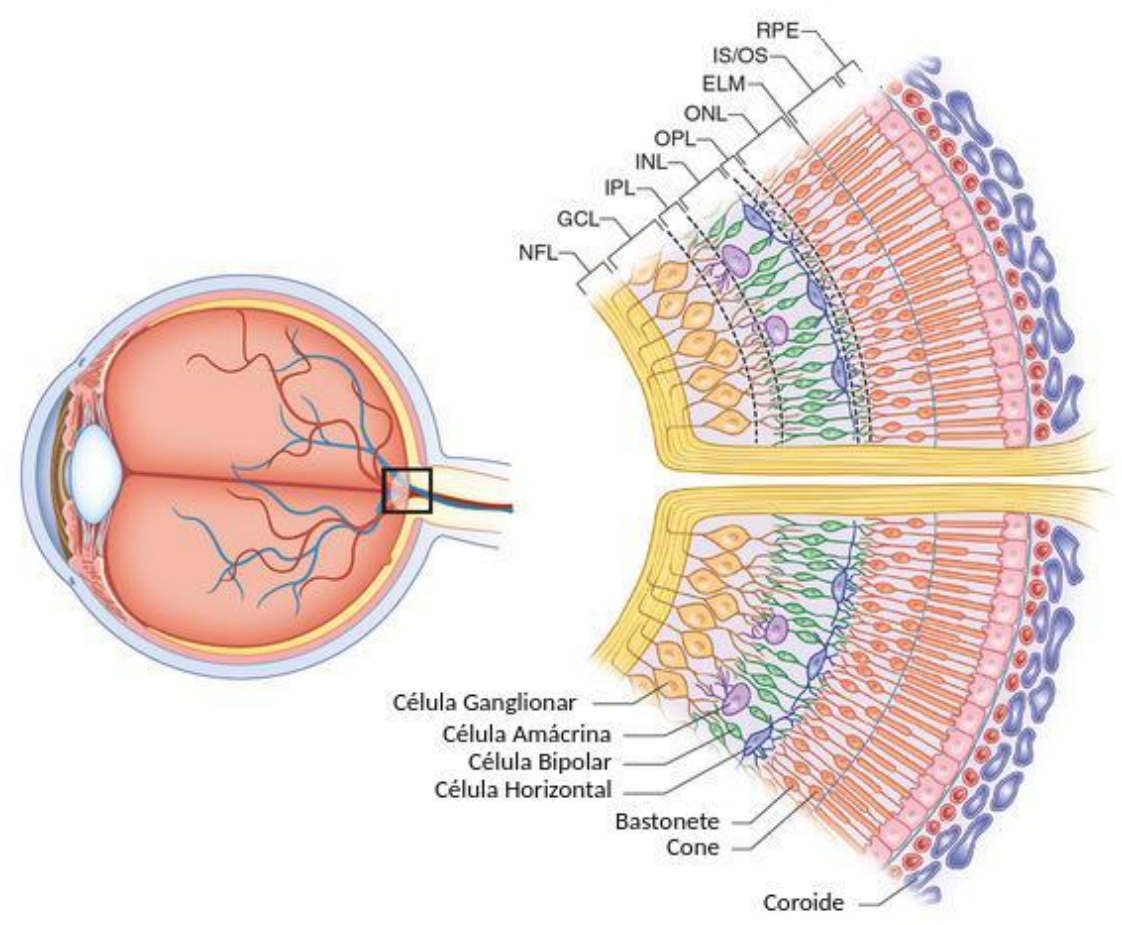

Figura 3: Principais camadas e células da retina. Quatro camadas de células fazem parte da sua formação. A primeira camada formada pelo epitélio pigmentar funciona como uma proteção. A segunda camada é composta pelas células fotorreceptoras (cones e bastonetes) que recebem a mensagem. A terceira camada é organizada por um conjunto de células (bipolares, horizontais e amácrinas) que transmitem a mensagem captada pelas células receptoras às células nervosas. A quarta camada é constituída pelas células ganglionares, cujos axônios, constituem o nervo óptico que transferem a imagem para o cérebro, onde é decodificada.

Fonte: Adaptado de [199]

(plexiformes) que contém os dendritos e as sinapses. A camada plexiforme externa (OPL, pelo nome em inglês - outer plexiform layer) situa-se entre a ONL e a INL. Nesta camada é onde os dendritos dos fotorreceptores, células horizontais e células bipolares interagem. A camada plexiforme interna (IPL) separa a camada INL e a GCL e é onde os axônios das células bipolares, amácrinas e ganglionares interagem. Também existem a camada de fibras nervosas (NFL) e a membrana limitante interna (ILM). A luz deve atravessar todas a essas camadas antes de iniciar a transdução do sinal nos bastonetes e cones. Embaixo dos fotorreceptores encontra-se a o Epitélio Pigmentoso (RPE, pelo nome em inglês), uma monocamada de células cuboides caracterizada pela elevada concentração de melanossomas das quais as células derivam sua cor. As células da RPE ajudam a nutrir a retina, facilitando a difusão de nutrientes da coroides e a remoção de resíduos ou segmentos de fotorreceptores desgastados [199]. Embora as células da camada de epitélio pigmentoso estejam em contato com os fotorreceptores, não existe conexão anatômica entre esses dois componentes da retina. É possível que depois de um trauma ou doença, a 


\begin{tabular}{|l|l|}
\hline Camada & Contêm \\
\hline Camada nuclear externa & Cones e bastonetes \\
(ONL) & Células horizontais, bipolares, amácrinas e de \\
Camada nuclear interna & Müller \\
(INL) & Células ganglionares e células amácrina deslocadas \\
Camada de células ganglio- & \\
nares GCL) & Interações entre fotorreceptores, células horizon- \\
Camada plexiforme externa & tais e bipolares \\
Camada plexiforme interna & Interações entre células bipolares, amácrinas e \\
(IPL) & células ganglionares \\
\hline
\end{tabular}

Tabela 1: Camadas celulares e sinápticas da retina

retina se separe do epitélio pigmentário. A tabela 1 mostra os principais tipos de células e interações nas camadas da retina.

A retina esta ancorada no disco óptico, onde as fibras nervosas (axônios das células ganglionares) juntam-se antes de passar através da esclerótica para formar o nervo óptico. Este ponto também é chamado de ponto cego, pois neste ponto não existem fotorreceptores (ver figura 4).
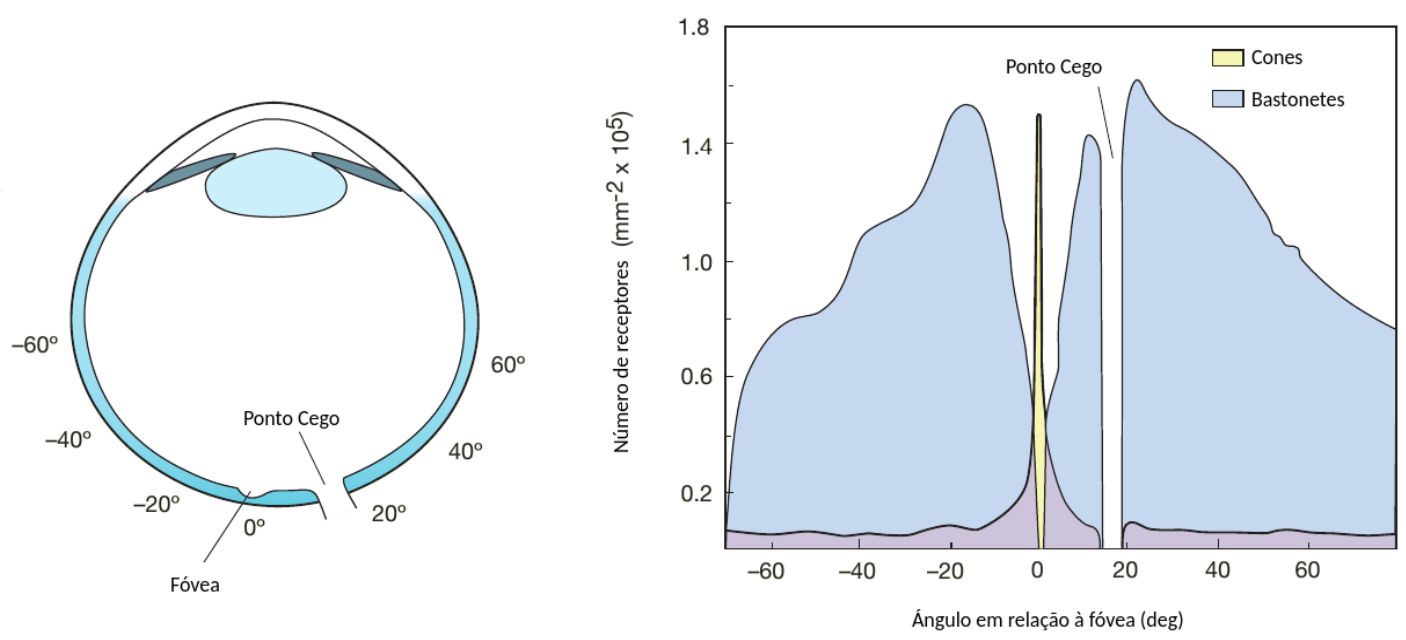

Figura 4: Distribuição dos fotorreceptores na retina

Fonte: Adaptado de Stephen (2013) [199]

O centro da parte posterior da retina é o eixo do olho, neste ponto a visão é a mais definida possível para cada indivíduo. Esta região parece pequena, amarela, oval e é chamada de mácula lútea. A mácula tem uma extensão aproximada de $5 \mathrm{~mm}$ de diâmetro. A retina neste nível possui certas características histológicas e histoquímicas que a diferenciam do resto da retina: 
- Menor espessura.

- Ausência de bastonetes.

- O número de cones é elevado, chegando a ter uma densidade de 140.000 cones $/ \mathrm{mm}^{2}$.

- Epitélio pigmentário mais denso.

- Grande conteúdo de pigmentos xantofílicos (luteína e Zeaxantina), os quais, acreditase, possuem uma função protetora contra os fototraumatismos.

Devido à cor amarela da mácula, esta absorve o excesso de luz azul e ultravioleta que entra no olho, agindo como um protetor solar natural para esta área da retina. A cor amarela provém do seu conteúdo de luteína e Zeaxantina, os quais são carotenoides xantófilos que são adquiridos mediante a dieta. A Zeaxantina predomina na mácula, enquanto a luteína esta presente no resto da retina. Existe alguma evidência que estes carotenoides protegem a região pigmentosa de alguns tipos de degeneração macular [109].

A mácula divide-se em várias zonas:

- Fóvea: encontra-se no centro da mácula numa concavidade que apresenta uma cor mais escura, com uma extensão de cerca de $1.55 \mathrm{~mm}$ de diâmetro. Na fóvea existe a maior concentração de cones (sem bastonetes). Apresenta uma zona avascular foveal, a qual observa-se mais escura nas angiografias de retina, isto pela falta de vascularização. A zona avascular é considerada como o centro óptico. Na fóvea, as células ganglionares e outras camadas da retina estão reduzidas para máxima sensibilidade e acuidade. Na figura 4, podem ser vistas a representação da densidade de cones e bastonetes na retina. Repare que existe um pico na quantidade de cones na fóvea e justamente nesse ponto a densidade de bastonetes cai para zero. Ao redor de $5 \mathrm{~mm}$ longe da fóvea a quantidade de bastonetes alcança seu máximo. Não existem fotorreceptores no ponto onde o nervo óptico deixa a retina, ou seja, no ponto cego [199].

- Fovéola: encontra-se no centro da fóvea e observa-se como um reflexo brilhante; possui um diâmetro de $0.35 \mathrm{~mm}$ aproximadamente.

- Zona parafoveal: é uma extensão da mácula que rodeia à fóvea e tem $0.5 \mathrm{~mm}$ de espessura aproximadamente. 
- Zona perifoveal: é uma extensão que rodeia à parafóvea e tem $3.5 \mathrm{~mm}$ de espessura aproximadamente.

Portanto, a mácula é responsável pela visão central e de alta resolução, a qual é possível com boas condições de iluminação.

O processamento visual na retina é feito por cinco tipos básicos neuronais: fotorreceptores, células horizontais, células bipolares, células amácrinas e células ganglionares. Os fotorreceptores fazem sinapse com as células bipolares, que transmitem a mensagem às células ganglionares. Na primeira sinapse que acontece na camada plexiforme externa (OPL), o sinal visual é regulado pelas células horizontais, que contribuem na resolução espacial da imagem que é projetada pela retina. Uma segunda sinapse acontece na camada plexiforme interna (IPL), aqui as células amácrinas regulam a resolução temporal que será processada pelas células ganglionares. A seguir, a função e características dos tipos de células mencionadas anteriormente serão explicadas em mais detalhe.

Fotorreceptores A absorção da luz pelos fotorreceptores esta determinada pelas propriedades dos seus pigmentos assim como das características espectrais, espaciais e temporais da luz incidente. A retina contem dois tipos de células foto-sensíveis: cones e bastonetes. Os cones respondem a elevados níveis de luminosidade e são responsáveis pela visão fotópica (diurna e a cor), com diferentes faixas de sensibilidade espectral. Os bastonetes são mais sensíveis à luz do que os cones; estes respondem à baixa intensidade luminosa e permitem a visão noturna ou escotópica.

Os fotorreceptores contém um segmento externo, um segmento interno, um corpo celular e um terminal sináptico (figura 5). Os segmentos externos dos bastonetes estão formados por uma acumulação de discos membranosos em formato de pilhas de moedas rodeados pela membrana celular, onde acontece a foto-transdução e encontra-se o pigmento foto-sensível chamado rodopsina. Nos cones, os discos estão formados pela própria membrana plasmática dobrada e as suas moléculas foto-sensíveis são chamadas opsinas. Os fotorreceptores, além de realizar a foto-transdução, comportam-se como neurônios, liberando neurotransmissores (glutamato) no seu terminal axônico.

Cones e bastonetes fazem contato com células bipolares e horizontais na camada OPL. No entanto, também existem conexões adicionais entre fotorreceptores. A ligação entre cones-L e M é indiscriminada, o que se vê refletido nas curvas de absorção dos comprimentos de onda destes cones. Morfologicamente, os pedículos dos cones-S são 
diferentes dos M e L, e raramente tocam cones vizinhos. Portanto, os cones-S não estão acoplados na rede de cones L/M. Existem também, junções entre os pedículos de cones e bastonetes. Isto permite que os sinais dos bastonetes entrem nos cones e que sinais que foram adquiridos pelos bastonetes possam ser detectados por neurônios de segunda ordem que parecem ser exclusivamente para levar informação dos cones. O acoplamento cone-bastonetes é muito dinâmico e influenciado pelos ritmos circadianos, aumentando à noite e diminuindo durante o dia [199].

Algumas características dos fotorreceptores são enunciadas a seguir.

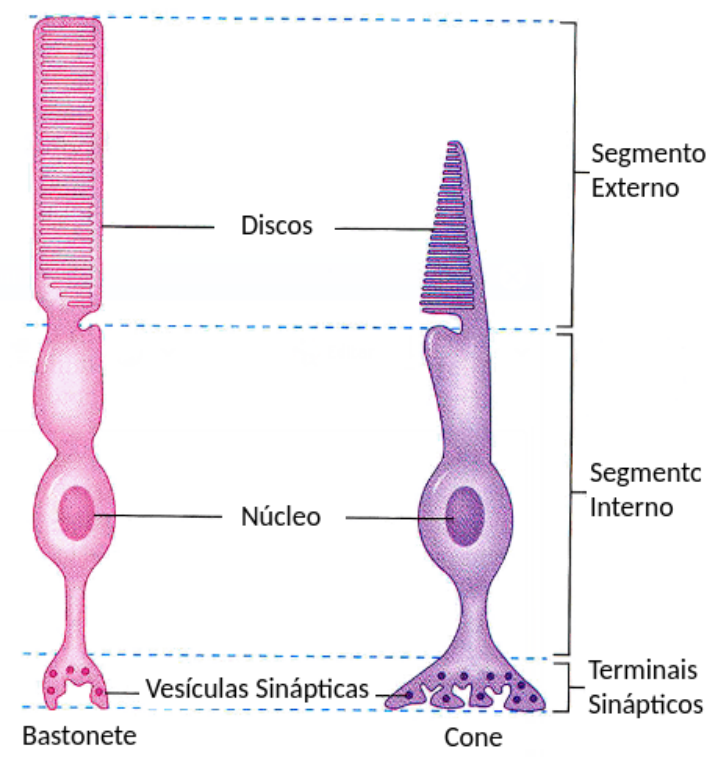

Figura 5: Estrutura dos fotorreceptores da retina

Fonte: Adaptado de [8]

Cones A resposta dos cones aos diferentes comprimentos de onda é chamado sensibilidade espectral. Na visão humana normal encontram-se três tipos de cones: os que são sensíveis aos comprimentos de onda curtos (cones-S, S-short pelo nome em inglês), médios (cones-M, M-medium pelo nome em inglês) e longos (cones-L, L-long pelo nome em inglês), ou também chamados informalmente de cones azuis, verdes e vermelhos, respectivamente. As pessoas que possuem os três tipos de cones têm visão tricromata. A falta de um ou mais tipos de cones ocasiona alguma deficiência na visão a cor ou cegueira de cor. Os indivíduos com cegueira à cor experimentam a inabilidade de distinguir entre dois grupos de cores, é o caso dos daltônicos que não conseguem distinguir entre o verde e o vermelho; estes possuem visão dicromato.

A sensibilidade específica aos comprimentos de onda dos cones deve-se à presença 
de três substâncias chamadas opsinas: A eritropsina tem a maior sensibilidade para os comprimentos de onda longos de ao redor de 650 nanômetros (luz vermelha). A cloropsina para comprimentos de onda médios de uns 530 nanômetros (luz verde). A cianopsina com maior sensibilidade para os comprimentos de onda curtos de uns 430 nanômetros (luz azul). A diferença entre os sinais recebidos a partir dos três tipos de cones permite que o cérebro perceba todas as cores possíveis, através do processo de oponência de cor. A cor amarela, por exemplo, é percebida quando os cones-L são estimulados um pouco mais do que os cones-M, e a cor vermelha é percebida quando os cones-L são estimulados significativamente mais do que os cones-M. Da mesma forma, tons de azul e violeta são percebidos quando o receptor $\mathrm{S}$ é estimulado mais do que os outros dois.

O espectro de luz visível que é percebido pelos diferentes tipos de cones e bastonetes pode ser visto na figura 6 .

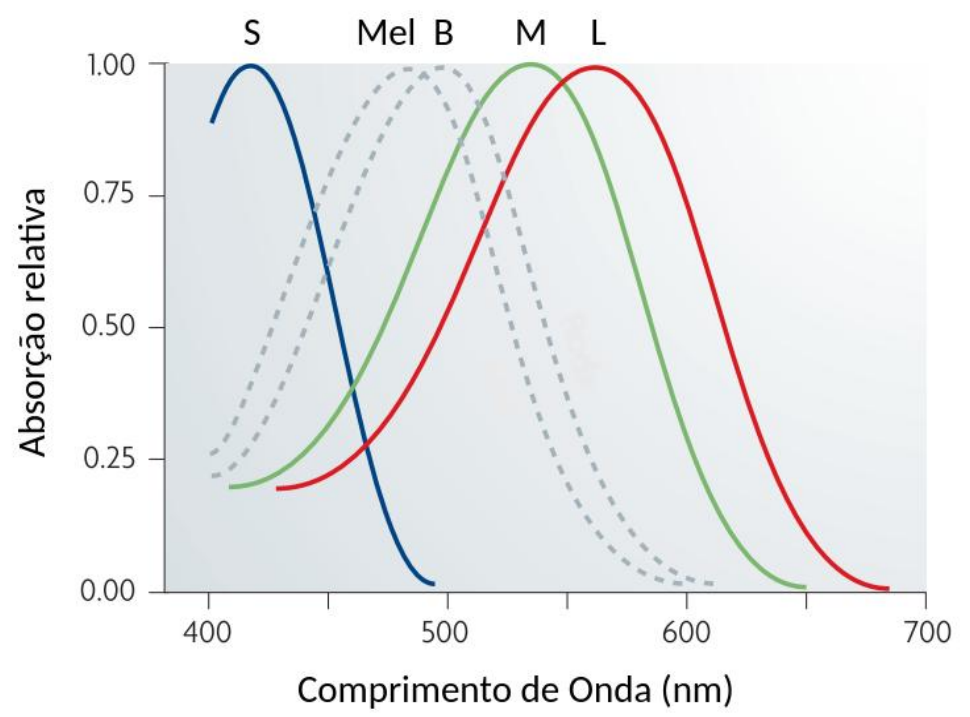

Figura 6: Espectro de luz visível que é amostrado por cada tipo de fotorreceptor. Cones S, M, L, Bastonetes (B) e Melanopsina (Mel)

Fonte: Adaptado de Solomon (2007) [189]

Bastonetes Os bastonetes estão presentes em quase toda a retina exceptuando a fóvea. Apresentam uma elevada sensibilidade à luz. O seu fotopigmento é a rodopsina, uma proteína que possui uma maior sensibilidade a comprimentos de onda perto de 500nm, ou seja, à luz verde-azulada. Os bastonetes se conectam em grupos e respondem aos estímulos que alcançam uma área geral, mas não têm a capacidade para isolar os pequenos detalhes da cena visual. Estas células são muito sensíveis, conseguindo detectar a energia de um fóton; e são responsáveis portanto, da visão em baixa luminosidade [83]. 


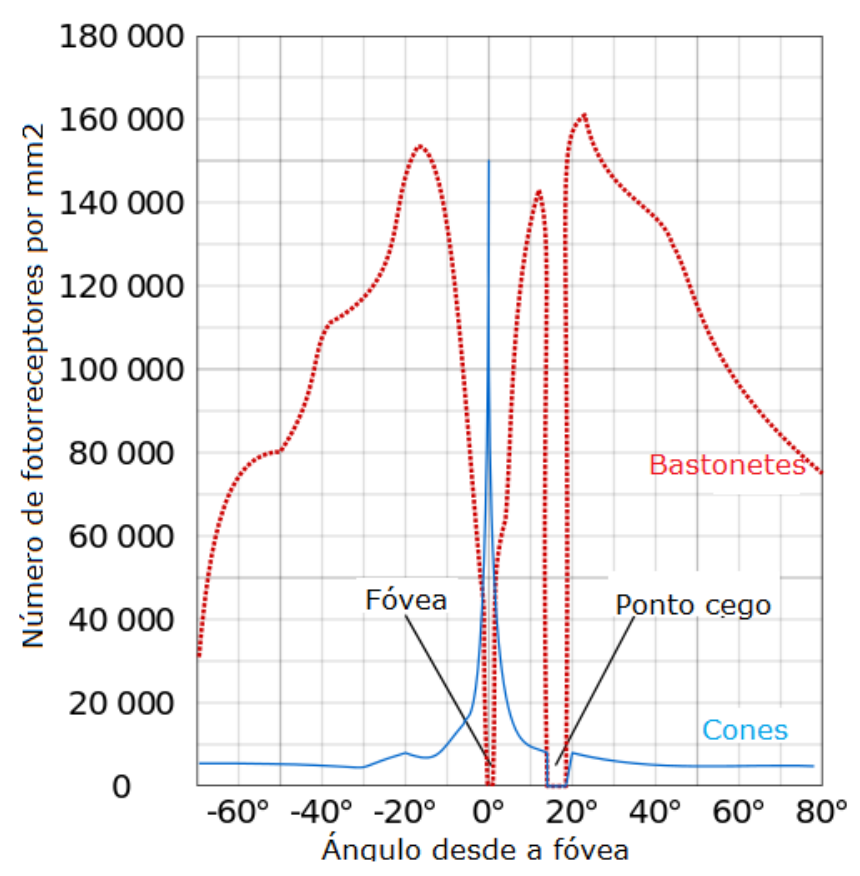

Figura 7: Distribuição dos fotorreceptores na retina

Fonte: Adaptado de [6]

Os bastonetes têm 3 caminhos principais pelos quais levam a informação até as células ganglionares [199]. Nesses 3 caminhos fazem conexões com células bipolares especializadas para bastonetes, células bipolares especializadas para cones e células amácrinas tipo II (AII). O acoplamento com as células bipolares especializadas para cones é bidirecional, ou seja, que os sinais que vem dos cones também podem passar das células bipolares (tipo cone) para as células amácrinas AII (caminho normal dos bastonetes).

Células Horizontais (HCs) As células horizontais são interneurônios que estabelecem as interações de curto e longo alcance entre fotorreceptores. Estas interações são conhecidas como sinais de feedback que ajustam o ganho da saída sináptica do fotorreceptor e da própria célula horizontal que se projeta na célula bipolar [107]. O acoplamento de células horizontais mediante junções tipo GAP medem o nível médio de iluminação que cai sobre uma região da superfície retiniana; então, subtraem um valor proporcional da saída dos fotorreceptores para manter a entrada do sinal no interior circuitos retinianos dentro da sua faixa de operação. As células horizontais geram oponência espacial em cones e células bipolares, oponência de cores em cones, células bipolares e subtipos de células horizontais cromáticas. As ações das células horizontais se propagam para frente na retina que podem ser identificadas na fisiologia das células ganglionares da retina e na percepção visual. As ações celulares horizontais são sintonizadas por neuromoduladores 
liberados por outros neurônios da retina, tais como a dopamina liberada pelas células amácrinas [156].

Na retina humana existem três tipos de células horizontais. As células horizontais de tipo I que não possuem axônio e conectam-se preferencialmente com cones-L e M, mas as vezes também com os cones-S. As células horizontais de tipo II ou células horizontais com axônio, comunicam-se de preferência com os cones-S no nível dos seus axônios terminais, mas também com outros tipos de cones no nível das suas terminações dendríticas e as células horizontais de tipo III que são semelhantes às células de tipo I, embora de maior tamanho, e evitam qualquer contato com os cones-S [14].

A resposta das células horizontais é uma hiperpolarização da membrana. Em grande parte, as conexões entre células horizontais acontecem mediante sinapses elétricas. Através de suas conexões transversais modulam a resposta do sistema fotorreceptor-célula bipolar. A ação inibidora da célula horizontal é a que modula as interações antagônicas entre fotorreceptores centrais e periféricos. Na ausência de luz células horizontais são despolarizadas pela liberação de glutamato por parte dos fotorreceptores. Tal despolarização ocasiona a hiperpolarização dos fotorreceptores próximos. Inversamente, na presença da luz os fotorreceptores liberam menor quantidade de glutamato, o qual hiperpolariza a célula horizontal, deixando uma despolarização dos fotorreceptores mais próximos. Assim, as células horizontais fornecem um feedback negativo aos fotorreceptores.

Na zona limite entre iluminação e escuridão, as diferenças na polarização das membranas dos fotorreceptores são máximas. A célula horizontal aumenta o contraste entre as duas zonas, facilitando a distinção dos contornos. Este mecanismo é a base da diferenciação do contraste. Assim, o antagonismo centro-periferia é a forma que utiliza o sistema visual para a detecção de bordas, independentemente do nível de iluminação. As células horizontais desempenham funções fundamentais na modulação da mensagem visual na primeira etapa do processamento visual. Devido ao seu amplo campo receptivo e ao seu tamanho e acoplamento, elas subtraem a iluminação média permitindo aos fotorreceptores responder a mudanças locais na iluminação local; com isto, adaptando os fotorreceptores à intensidade luminosa. Elas contribuem à formação do campo receptor antagônico das células bipolares e ganglionares, o que colabora no fenômeno de discriminação do contraste. Em espécies de vertebrados não primatas contribuem á discriminação da cor [211]. Estudos sugeriram que elas são responsáveis pela oponência de cor verde/vermelha nas células ganglionares Midget de primatas [199]. 
O feedback HC-cone pode incrementar o ganho da sinapse do fotorreceptor dependendo da polarização relativa dos diferentes tipos de fotorreceptores. Isto ocorre porque a intensidade do sinal de feedback varia com a quantidade de luz que incide sobre os fotorreceptores individuais. Os cones não estimulados ou fracamente estimulados recebem um sinal de realimentação mais forte do que os cones diretamente estimulados pela luz [99]. A consequência desse arranjo é que, se a luz do ambiente estiver avermelhada (como durante o nascer ou o pôr do sol), os cones menos sensíveis à luz vermelha (cones S e M) e, portanto, menos estimulados diretamente, receberão o feedback mais forte. Sua saída terá um ganho maior do que a dos cones-L, e a saída da camada de fotorreceptores como um todo será mais azul-esverdeada; e isso efetivamente contrabalança a vermelhidão no ambiente. Este "balance" ajusta dinamicamente a sensibilidade espectral dos fotorreceptores às características do iluminante; isto basicamente representa o substrato neuronal para a constância da cor, que é a capacidade do sistema visual de perceber as cores de maneira relativamente constante, independentemente da composição espectral da luz ambiente.

Células bipolares (BCs) As células bipolares conectam-se com as terminações sinápticas dos fotorreceptores e transmitem os sinais às células ganglionares. Na retina humana tem-se descrito vários tipos morfológicos de células bipolares. A maioria correspondem a células bipolares para cones, enquanto um único tipo de célula bipolar tem sido descrita para os bastonetes. A célula bipolar para os bastonetes não faz conexão direta com as células ganglionares, em lugar disso, faz sinapse com as células amácrinas [4].

Células amácrinas (ACs) As células Amácrinas formam um grupo diverso (morfológica e fisiologicamente) de interneurônios da retina principalmente inibitórios. Recebem conexões diretas das células bipolares e outras células amácrinas, e estabelecem ao mesmo tempo conexões com as células ganglionares e dão feedback às células bipolares. Portanto, formam uma via de associação lateral ao nível da camada plexiforme interna (IPL - a camada retinal onde as células bipolares e as células ganglionares formam sinapse). As células Amácrinas são responsáveis do $70 \%$ da informação que entra nas células ganglionares. As células bipolares, que são responsáveis do restante $30 \%$ de informação que chega as células ganglionares são reguladas pelas células amácrinas.

Cada tipo de célula amácrina une-se com um tipo particular de célula bipolar, e geralmente tem um neurotransmissor característico. Existem aproximadamente 40 tipos diferentes de células amácrinas, e a maioria não possuem axônios. 
Algumas funções específicas das células amácrinas são:

- Interceptar às células ganglionares da retina e/ou células bipolares na camada IPL

- Contribuir com a comunicação vertical dentro das camadas retinianas

- Realizar funções parácrinas como a liberação de dopamina e acetilcolina

- Através das suas conexões com outras células da retina nas sinapses e na liberação de neurotransmissores, contribuem à detecção do movimento direcional, à modulação do ritmo circadiano e ao controle de alta sensibilidade da visão escotópica.

- Nos movimentos oculares rápidos, a imagem visual não fica desfocada. Isso ocorre porque uma onda de inibição varre a retina interna, como um branco vertical na tela de uma televisão. Num estudo, a onda inibitória associada com sacadas foi atribuída a células amácrinas de campo largo [174].

Células Ganglionares (GCs) As células ganglionares possuem um corpo celular volumoso e ramificações dendríticas que formam sinapse no nível da camada plexiforme interna com as terminações das células bipolares e amácrinas. Seu axônio esta no nível da camada das fibras do nervo óptico e sua mielinização acontece no nível do nervo óptico, fora do globo ocular. Este axônio vai até o corpo geniculado lateral, onde ocorre a próxima sinapse da via visual.

O campo receptivo da célula neuronal da retina é a região no espaço visual que faz com que ela mude seu estado na presença de algum estímulo visual. As células ganglionares (GC) têm dois tipos de resposta dependendo do campo receptivo da célula. O campo receptivo destas células compreende uma área central aproximadamente circular, onde a luz tem o efeito de disparar a célula (centro ON), e um exterior anular onde a luz tem o efeito oposto (periferia OFF). Nas células tipo ON, um incremento na intensidade da luz no centro do campo receptivo ocasiona um incremento na taxa de disparo. Nas células tipo OFF tal incremento faz com que essa taxa decresça. As células ganglionares obedecem as regras de estratificação que governam a retina interna. Assim, as GC-OFF recebem entradas das $\mathrm{BC}-\mathrm{OFF}$ e as GC-ON recebem entrada das $\mathrm{BC}-\mathrm{ON}$.

Células Ganglionares Midget (GC-M) As células ganglionares Midget podem ser de tipo ON ou OFF. Elas são numericamente dominantes na retina. No centro da 
retina existe uma correspondência 1:1:1 entre cones, BC midget e GC midget. Assim, parece ser que as GC midget transmitem uma versão de alta acuidade da cena visual a partir do centro do seu olhar, à retina central. A proporção de 1:1:1 também significa que as células ganglionares midget codificam a cor de acordo com o tipo de cone no início da cadeia. Depois de $2 \mathrm{~mm}$ ou $10^{\circ}$ da fóvea, estas células formam clusters dendríticos que recebem informação de múltiplas BC midget. As GC midget projetam-se nas camadas parvocelulares do corpo geniculado lateral

Células Ganglionares Parasol (GC-P) As células ganglionares Parasol possuem grandes somas e amplos campos dendríticos. Existem de tipo ON e tipo OFF. Fisiologicamente, têm propriedades transientes e não-lineares. Elas respondem a estímulos de alta frequência temporal e projetam-se nas camadas magnocelulares do corpo geniculado lateral. Estas células ganglionares embora recebam informação dos cones, não codificam cor.

Codificação espacial A retina não simplesmente envia uma imagem no cérebro. A retina comprime a informação visual para que possa passar pelo nervo óptico. Tal compressão é necessária, pois existem muitos mais fotorreceptores do que células ganglionares. A compressão é realizada pelas estruturas "centro-periferia" das células bipolares e ganglionares. Como foi mencionado antes, existem dois tipos de estruturas "centro-periferia" nas células ganglionares da retina. As de centro ON e as de centro OFF. As de centro ON têm peso positivo no centro e peso negativo no exterior. As de centro OFF são o oposto. O centro de peso positivo é mais comum e é conhecido como excitatório, já o centro de peso negativo é conhecido como inibitório. Em teoria, este processo de oponência espectral realizado pelas células ganglionares de centro-periferia remove informação redundante para produzir uma codificação eficiente [30].

As estruturas centro-periferia não existem fisicamente (ou seja, não é possível vê-las mediante uma tinção histológica). Este tipo de estruturas dependem das conexões entre as células bipolares e ganglionares. As estruturas centro-periferia são matematicamente equivalentes aos algoritmos de detecção de bordas utilizados para extrair ou realçar as bordas dos objetos dentro do seu campo visual. Com o objetivo de permitir outras funções mais complexas no cérebro, a retina é o primeiro passo para extrair ou classificar objetos numa cena. Na figura 8 encontra-se ilustrado como seriam este tipo de estruturas nas células ganglionares. 


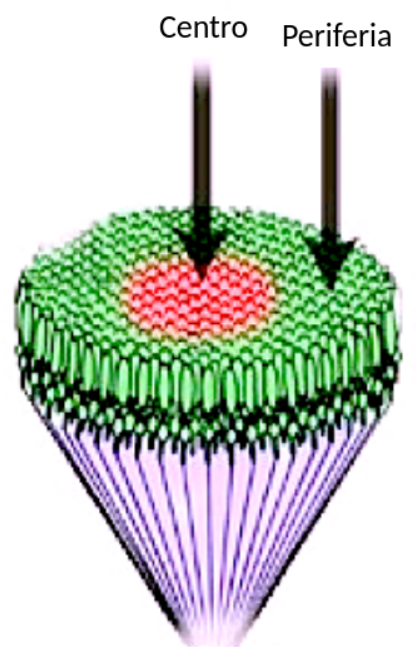

Célula Ganglionar

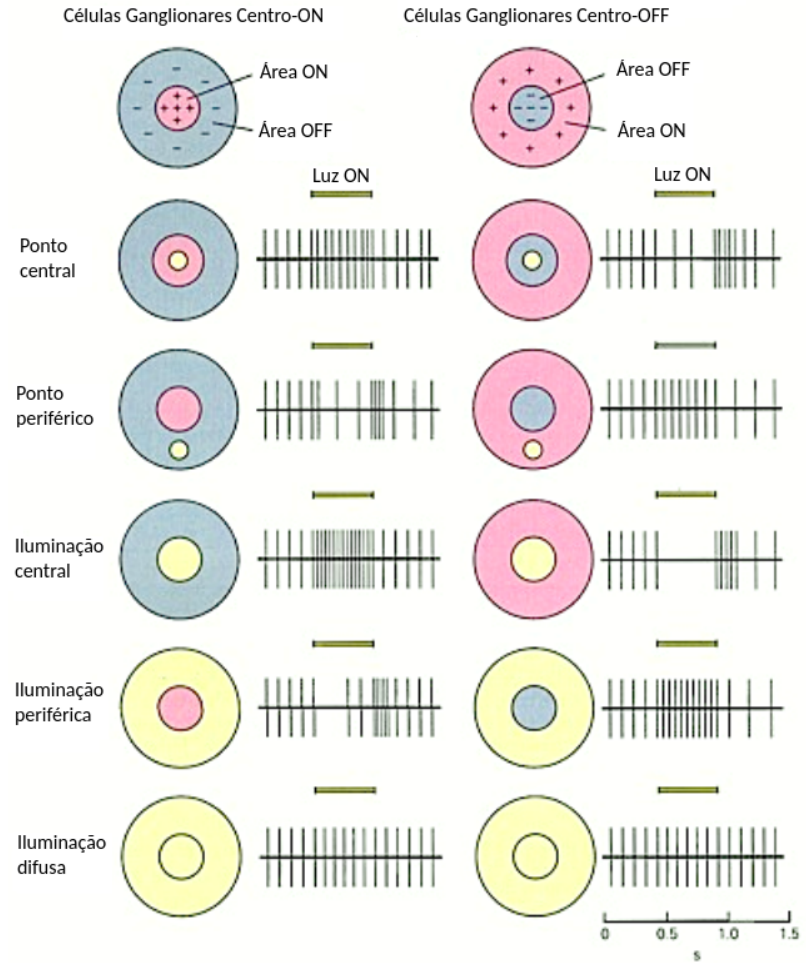

Figura 8: Estrutura ON-OFF das células ganglionares

Fonte: Adaptado de [3]

As células ganglionares também se diferenciam pela sensibilidade cromática e o tipo de adição espacial. Como mencionado, as células que apresentam adição linear (um fotorreceptor por célula ganglionar) são as células Midget (GC-M), e aquelas que apresentam uma adição não-linear são as células Parasol (GC-P), mas as vezes essa correspondência não é tão simples assim. Existem também as células ganglionares tipo K. As células ganglionares Midget são as mais numerosas na retina, ao redor de $80 \%$ do total, conectando-se ao caminho Parvocelular; o restante $20 \%$ é dividido em 10\% de células ganglionares Parasol conectadas ao caminho Magnocelular e 9\% de células ganglionares de tipo biestratificadoK que conectam-se ao caminho Koniocelular [102].

A resolução espacial das células ganglionares da retina dependem do número de fotorreceptores que convergem na célula ganglionar. Caso una célula ganglionar receba a entrada de muitos fotorreceptores a resolução espacial vai ser fraca, pois está realizando a amostragem de uma área ampla do campo visual; portanto, não é possível indicar precisamente à localização espacial da origem de um determinado estímulo. As células ganglionares Midget têm relativamente poucos fotorreceptores chegando nelas. Como consequência disto, as células Midget têm boa resolução espacial mas pouca resolução temporal. As células ganglionares Midget estão bem adaptadas para realizar o processa- 
mento de pequenos alvos e detalhes finos. Em contraste, as células ganglionares Parasol recebem a entrada de um considerável número de fotorreceptores e têm campos receptivos dois ou três vezes maiores que os campos receptivos das células ganglionares Midget. Estas características fazem com que as células Parasol sejam ideais para detectar estímulos de movimento no ambiente visual, e consigam redirecionar a atenção rapidamente para um novo estímulo. Pelo fato de uma única célula Parasol amostrar um amplo campo visual, não possuem o mesmo grau de resolução espacial que as células Midget e portanto, percebem uma visão mais geral da cena. As células Midget são o tipo mais comum encontrado na fóvea, no entanto, também podem estender-se um pouco até parafóvea e regiões periféricas. As células Parasol são o tipo mais comum nas regiões extra-foveais. Devido a que as células Parasol encontram-se na visão periférica, nesta região de pouca resolução espacial as imagens são pouco definidas. Os axônios das células Parasol são mais grossos e têm mais mielinização que os das células Midget, fazendo com que estes tenham uma condutância maior. Tal condutância implica que as células Parasol têm a capacidade de detectar estímulos a altas frequências temporais. As diferenças nas propriedades de resposta das duas células ganglionares principais (Parasol e Midget), faz possível compreender por que as palavras são reconhecidas mais rapidamente quando são apresentadas na fóvea.

Os neurônios koniocelulares possuem moderada resolução espacial e velocidade de condução intermediária. Seus campos receptores recebem informação dos S-cones de centro ON [43]. As células $\mathrm{K}$ não têm sido estudadas tão extensivamente quanto as células Midget ou Parasol, mas pensa-se que possam realizar uma função de modulação do córtex visual. O $90 \%$ destas células transmitem sua informação ao corpo geniculado lateral (LGN), e o 10\% faltante projeta-se no colículo superior (SC).

Visão a cor A maioria dos humanos são tricromatos, com cones-L, M e S. A visão a cor fornece uma variável adicional para melhorar a discriminação visual. Esta organizada em dois sistema oponentes, verde/vermelho (M/L) e amarelo/azul (L+M, S; onde o amarelo esta formado pelo verde + vermelho). Portanto, não há tons vermelho/verde nem misturas de azul e amarelo; se diz que estes sistemas possuem oponência de cor. As GC-M estão concentricamente organizadas como verde/vermelho ou vermelho/verde. A entrada no centro é espectralmente pura pela conexão 1:1:1 com cones únicos. Existe alguma controvérsia sobre a origem da oponência de cor da periferia; No entanto, existem alguns registros em GC-M de primatas que indicam que a informação da periferia é cromaticamente mista, ou seja, que é uma média entre os cones ao redor. As células horizontais 
estão adequadamente conectadas para fornecer o sinal da "periferia" espectralmente misturado porque elas entram em contato com os cones vermelho e verde indiscriminadamente. Embora o mecanismo exato de feedback da célula horizontal seja controverso, isso indica fortemente que a oponência de cor é produzida pelo feedback da célula horizontal na retina externa [57]. Evidências fisiológicas sugerem que a oponência da cor azul/amarela se origina na retina externa [56].

Visão de contraste Na camada de células ganglionares inicia-se a codificação das três dimensões de cores de contraste. As células Midget e Parasol podem receber informação somada dos cones-L e M tanto na periferia como no centro de seu campo receptivo [120]. Desta forma, a comparação dessas informações indica a diferença de intensidades luminosas entre duas áreas vizinhas. Os campos receptivos das células Midget comparam os sinais dos comprimentos de onda longos e médios, que representam a condição inicial da percepção do contraste de cor verde-vermelho ou canal de oponência verde-vermelho. As células ganglionares biestratificadas tipo K comparam os sinais de comprimentos de ondas curtos (excitatórios) com os sinais somados de comprimentos de ondas médios e longos (inibitórios). Tal processamento representa o início da percepção de contraste de cor azul/amarelo ou canal de oponência azul/amarela.

Um objeto só consegue ser identificado caso haja contraste entre ele e o ambiente ao seu redor. Existem ao menos cinco tipos diferentes de contraste que podem diferir um alvo do fundo sobre o qual ele é observado [165]. Esses contrastes são: contraste espacial de luminância, representado pela diferença de intensidades luminosas no domínio do espaço entre o alvo e o fundo; contraste espacial de cor representada pela diferença de conteúdo espectral entre o alvo e o fundo; o contraste de texturas representado pelas diferentes características de linhas que compõem o alvo e fundo; contraste temporal de luminância ou crominância; e contraste de disparidade ocular, que é a diferença de posicionamento da imagem sobre os dois olhos. Esse é o princípio da camuflagem natural: quanto mais propriedades o alvo compartilhar com o fundo, mais difícil será para um observador distinguir os elementos de uma cena visual. O tipo de contraste mais amplamente estudado em diferentes seres vivos é o contraste espacial de luminância.

As imagens naturais apresentam uma mescla de cores com diferentes intensidades luminosas ao longo do domínio espacial. As células ganglionares retinianas separam as informações de contrastes de luminância (células Midget e Parasol) das informações de contraste de cores (células Midget e K). Assim é comum que em experimentos científicos 
sejam utilizados estímulos que isolam as informações de luminância ou de cor com o objetivo de estudar separadamente os processamentos realizados por essas diferentes classes celulares [190].

No estudo do processamento do contraste do sistema visual é bastante usada a estimativa do limiar de detecção do contraste. O contraste limiar é o menor contraste que gera a resposta do sistema visual, mas ele não representa um valor fixo e sim um valor probabilístico. É comum no estudo de sistemas sensoriais converterem-se os valores de limiar em valores de sensibilidade. Uma forma de fazer isso é achar a função inversa do contraste limiar para representar a sensibilidade ao contraste. Os primeiros experimentos para testar a sensibilidade do sistema visual humano aos contrastes espaciais foram aqueles utilizando métodos psico-físicos nos quais eram mostrados estímulos de contraste espacial de luminância com diferentes frequências espaciais.

A sensibilidade ao contraste espacial de luminância pode ser estimada em diferentes frequências espaciais, na qual pode ser ajustada uma função com forma de sino (figura 9). A curva ou função de sensibilidade ao contraste espacial de luminância separa o mundo do visível (abaixo da curva) do mundo do invisível (acima da curva). A diminuição da sensibilidade ao contraste em frequências espaciais altas é devida a fatores ligados à transmissão de contrastes pela óptica do olho, enquanto a atenuação nas frequências espaciais baixas é devida a fatores neurais como a organização dos campos receptivos dos neurônios visuais em regiões centrais e periféricas antagônicas. Assim, a função de sensibilidade ao contraste pode ser afetada por dificuldades na geração de estímulos com o contraste espacial desejado, pelas características da óptica ocular, pela biofísica da foto-transdução e pelo funcionamento dos neurônios da via visual [190].

Células Ganglionares Intrinsecamente Fotossensíveis (ipRGCs) As células ganglionares intrinsecamente fotossensíveis (ipRGCs - intrinsically photosensitive Retinal Ganglion Cell) são fotorreceptores atípicos separados dos clássicos cones e bastonetes; estes contém o fotopigmento melanopsina. Existem vários subtipos de ipRGCs (sugere-se que existem 5 subtipos denominados M1 a M5) que se diferenciam pela sua morfologia, como por exemplo campo dendrítico, estratificação, tamanho do soma e projeções dos axônios. Cada subtipo possui diferentes respostas ao estímulo luminoso e características eletrofisiológicas. Em primatas o pigmento melanopsina apresenta um pico de expressão em $483 \lambda$ (ver figura 6).

As ipRGCs M1 são predominantemente responsáveis pelo ciclo circadiano (CC) e o 


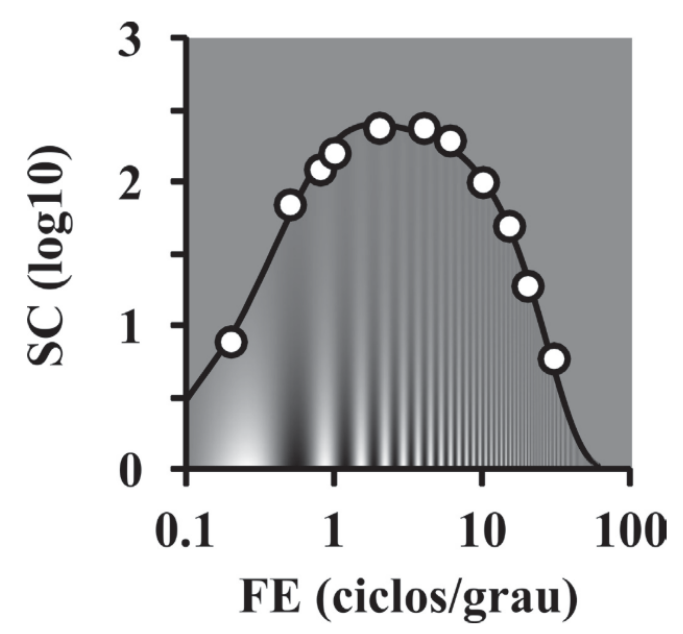

Figura 9: Curva de Sensibilidade ao contraste (SC) versus Frequência Espacial (FE).

Fonte: Sousa (2013) [190]

reflexo pupilar (RP). As ipRGCs não-M1 pensa-se são responsáveis pelas reações que formam imagem mediante projeções no corpo geniculado lateral dorsal e pelas projeções em outras regiões que incluem a amídala; o qual sugere contribuições ao circuito da ansiedades, dor e medo [179]. Zhao et al. [243] mencionam a diversidade funcional dos diferentes tipos de ipRGCs (estudo realizado em camundongos). Eles encontraram que as células M2-M5 poderiam detectar diferenças espaciais na intensidade da luz, implicando uma capacidade de analisar a forma dos estímulos visuais; os cinco tipos de ipRGCs responderam de forma robusta a luzes em movimento, e as células M1-M4 parecem responder otimamente a velocidades diferentes, sugerindo elas poderiam ter a capacidade de analisar a velocidade do movimento; e as células M1-M4 projetam-se para o colículo superior, uma área do cérebro conhecida por detectar objetos no cenário visual, sugerindo que as informações de forma e movimento sinalizadas por esses quatro tipos de ipRGCs poderiam contribuir para esta função visual.

As ipRGCs combinam a entrada dos caminhos de foto-transdução dos bastonetes e cones, altamente sensíveis e rápidos, com sua própria resposta lenta mediada pela melanopsina. Esta informação integrada é então transmitida a numerosas regiões do cérebro envolvidas na visão que "forma"e "não forma"imagem, tais como o núcleo supraquiasmático (SCN) para a resposta circadiana, o núcleo olivar pré-tectal (OPN) para o reflexo pupilar e o corpo geniculado lateral dorsal (dLGN) para a formação da imagem. Além das projeções principais e mais estudadas que foram mencionadas, as ipRGCs projetam em outras regiões cerebrais. Portanto, hoje existe evidência experimental de que as ipRGCs além de modular o ciclo circadiano e o reflexo pupilar, também contribuem com 
a modulação de sistemas neuroendócrinos, ansiedade e aversão à luz, e até mesmo uma contribuição significativa para a função visual tálamo-cortical. Além disso, essas novas funções de ipRGCs têm aplicações em condições clínicas e diagnósticos de degeneração da retina e distúrbios do sono [179]. Algumas unidades de ipRGCs têm sido encontradas no Córtex visual primário (V1) e estariam envolvidas na percepção da luminância e o brilho [192].

Assim como o ciclo circadiano, a fotofobia, que é uma condição na qual inclusive baixos níveis de iluminação geram desconforto e dor ocular, também está presente em indivíduos visualmente cegos [24]. Além disso, pessoas com fotofobia são muito sensíveis à luz azul e experimentam dor ao longo da exposição à luz, consistente com o papel das ipRGCs neste tipo de condição. Estudos em camundongos mostraram que animais com as ipRGCs intatas evitaram luzes brilhantes, enquanto animais sem ipRGCs mostraram pouca aversão a este tipo de luzes, sugerindo que as ipRGCs são o circuito primário para a aversão à luz, e portanto, da fotofobia [179]. No entanto, estudos em humanos com sensibilidade à luz não são tão conclusivos [115].

Como mencionado, o Reflexo Pupilar é mediado pelas ipRGCs as quais também recebem entrada dos cones e bastonetes. As respostas pupilares dependentes de melanopsina são sensíveis a comprimentos de onda curtos, possuem um limiar alto para sua ativação e são muito mais lentos para se ativarem e desativarem, quando comparados com as respostas dos cones e bastonetes. Desta forma, devido à diferença nas propriedades de resposta entre os fotorreceptores, e à entrada de informação proveniente dos cones e bastonetes as ipRGCs podem exercer suas funções em baixas intensidades luminosas [199]. Ainda não é totalmente compreendido como uma pequena população de células ganglionares intrinsecamente fotossensíveis, podem interagir com as diferentes classes de fotorreceptores para modular a função visual humana [239].

As respostas das ipRGCs que são mediadas pelos cones e bastonetes têm sido caracterizadas e sugerem que este tipo de célula constitui um caminho diferente que projeta do nervo óptico até o córtex visual e que leva informação de luminância e oponência de cor [59]. De fato, este tipo de ipRGCs são chamadas de gigantes e possuem um campo receptivo S_OFF L+M_ON. De acordo com a oponência de cor dos cones, estas ipRGCs gigantes projetam no LGN; e assim, no primata tricomático os caminhos que "formam imagem" e os que "não formam imagem" estão combinados e o sinal baseado na melanopsina poderia contribuir com a percepção visual consciente [59]. Coletivamente, essas células projetam-se além dos alvos cerebrais conhecidos das ipRGCs para inervar 
fortemente o Colículo Superior e o Corpo Geniculado lateral dorsal, núcleos organizados retinotopicamente mediando a localização e discriminação de objetos [64].

Como apresentado na figura 6 a melanopsina possui um pico de sensibilidade em 485nm aproximadamente. No entanto, numa pesquisa onde foi apresentado um estímulo para as células ganglionares que expressam melanopsina, os participantes descreveram o estímulo como tendo uma cor amarelo-alaranjada ou esverdeada, mas quando as cores da descrição foram restrita às quatro tonalidades básicas, a cor do estímulo foi descrita como amarelada ou esverdeada, com variabilidade entre participantes. Os autores da pesquisa [239] discutem que estas diferenças entre os relatos verbais podem refletir o grau de intrusão dos cones no estímulo. Então, se o estímulo que visa ativar diretamente a melanopsina (assumindo que realmente cumpre essa função exclusiva) está gerando uma percepção de cor, implicaria que esta envolvida em processos corticais.

Zele et al. (2018) [240] sugerem que a fotorrecepção da melanopsina contribui para a detecção visual humana, processamento temporal e de cor, ou seja, a visão consciente. Eles mostraram que a suposta visão que forma de imagens mediada pela melanopsina efetivamente corresponde a uma propriedade de resposta oponente S_OFF L+M_ON, com uma resolução temporal média de até aproximadamente $5 \mathrm{~Hz}$ e limiares de ativação 10 vezes mais altos que os da visão vermelho-verde. Propõem que as células ganglionares intrinsecamente fotossensíveis que expressam melanopsina, pela sua capacidade de sinalização de cor e de integrar mudanças de luz lentas, poderiam ser o quinto tipo de fotorreceptor que gera a visão periférica.

As funções de formação de imagem das ipRGCs vem sendo pesquisadas ativamente. No presente ano, Allen et al. (2019) [21] verificaram que observadores saudáveis podem detectar sinais sinusoidais com alta radiância quando chegam na retina periférica em baixas frequências espaciais $(\leq 0,8 \mathrm{cpd})$ e temporais $(\leq 0,45 \mathrm{~Hz})$; com isto, fornecendo a visão de formas, permitindo a detecção e a discriminação de grades em baixas frequências espaço-temporais, logo, influenciando a aparência das imagens cotidianas. Estes dados estariam identificando à melanopsina como uma nova origem potencial para aspectos da visão espacial em humanos. Recentemente, Zele et al. [239] mostram que na retina periférica a interação entre os sinais dirigidos pela melanopsina e os cones afetam a visão consciente formadora de imagens. Declaram que a ativação da melanopsina aumenta a sensibilidade ao contraste de cada uma das três vias visuais (Magno, Parvo e Koniocelular) mediadas pelos cones; isto implicaria que a excitação da melanopsina pelo estímulo luminoso modularia a sensibilidade ao contraste que é mediada pelos cones [30]. 
Desta forma, pensa-se que a melanopsina pode fornecer sinais de entrada para as três vias retinogénicas principais [30], e que a interação entre a melanopsina e os diferentes cones aconteceria no nível da retina, onde as ipRGCs modulariam o ganho das outras células ganglionares para ajustar o fluxo de informação que vai pelo nervo óptico ao cérebro; como mostrado em retina de camundongo onde as ipRGCs fornecem feedback aos fotorreceptores por meio das células amácrinas dopaminérgicas para modular a adaptação à luz [239].

Até agora pesquisadores psicofísicos estão pensando na melhor forma de estimular estas células ganglionares fotossensíveis corretamente e pensando em quais tipos de experimentos poderiam ser feitos para investigar as relações entre as ipRGCs e os diferentes caminhos/sistemas de transmissão de informação pelo nervo óptico.

No artigo publicado por [115] et al em 2017 são enunciadas as implicações clínicas das funções não-visuais das das ipRGCs [115]. Embora, agora que se conhecem algumas das funções visuais das ipRGCs novas relações entre disfunções visuais e estas células possam ser formuladas.

A imagem 10 mostra um esquema dos principais centros cerebrais nos quais as ipRGCs projetam suas fibras nervosas e tem-se encontrado implicações clínicas.

Células Gliales - Células de Müller As células de Muller foram chamadas de "fibras radiais" e reconhecidas como as principais células gliais da retina dos vertebrados. Embora existam outras células gliais na retina, como astrócitos, microglia e oligodendrocitos. A células gliais são constituintes essenciais do tecido. Por exemplo, as células de Müller parecem constituir o "núcleo" de unidades colunares de grupos clonais e funcionalmente relacionados de neurônios. Sua principal função é apoiar o funcionamento neuronal, orientando a luz em direção às células fotorreceptoras, removendo o excesso de moléculas neurotransmissoras do espaço extracelular e realizando uma depuração eficiente do excesso de íons extracelulares de potássio. As duas últimas funções também são cruciais para a sobrevivência neuronal e são acopladas à depuração da água, que também é essencial. Em alguns casos de lesões da retina, as células de Müller tornam-se reativas, e todas as funções acima mencionadas são prejudicadas. No entanto, as células de Müller desdiferenciadas podem proliferar e até servir como células-tronco para a regeneração de uma retina danificada [38].

Antes que a luz chegue nos fotorreceptores, ela deve atravessar toda a retina. As 


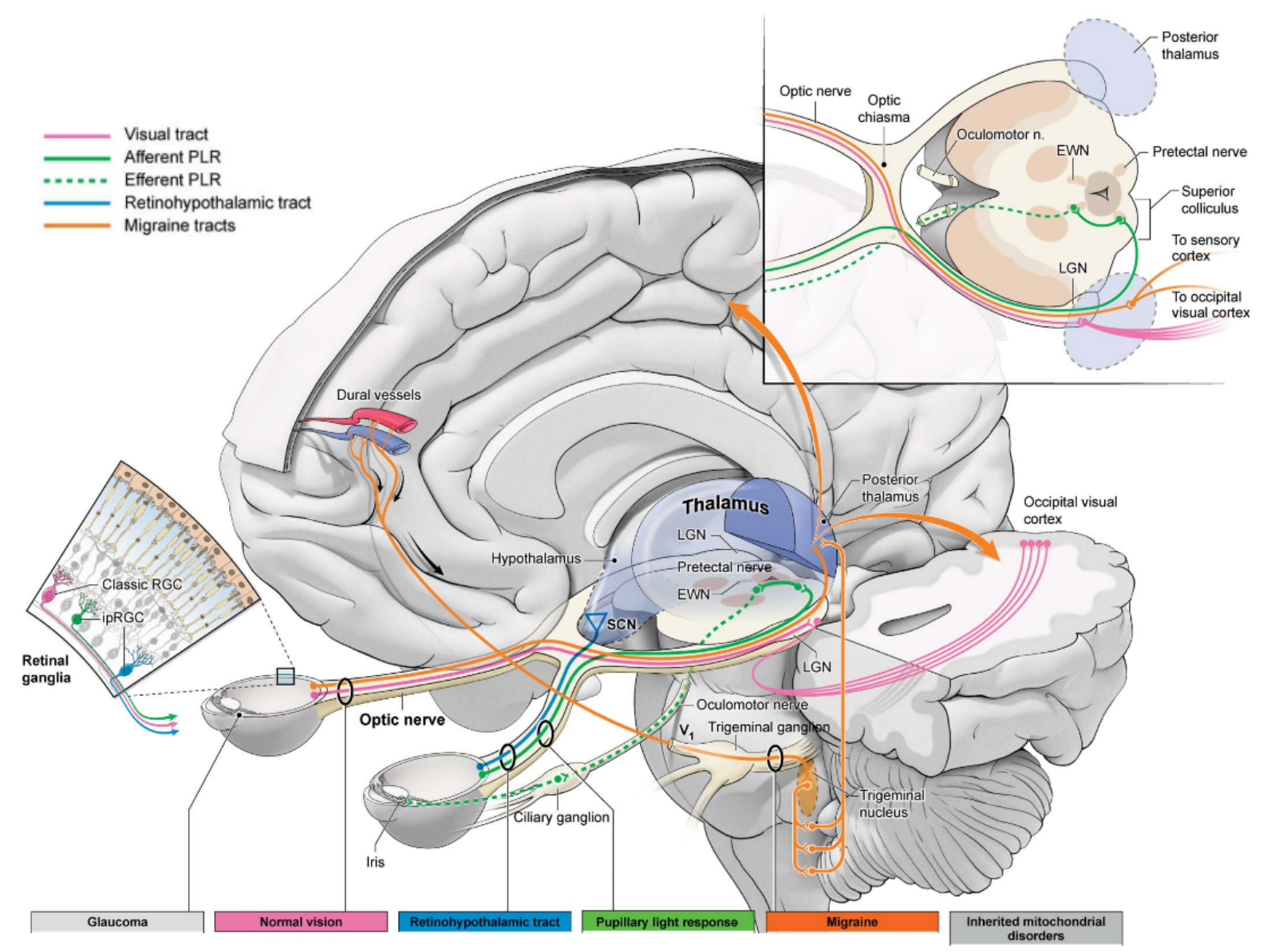

Figura 10: Centros cerebrais nos quais as ipRGCs projetam suas fibras nervosas e tem-se encontrado implicações clínicas [115]

Fonte: Ksendzovsky (2017) [115]

células de Müller servem como guias de onda dependentes do comprimento de onda da luz, concentrando a parte verde-vermelha do espectro de luz visível nos cones e permitindo que a parte azul/roxa vaze nos bastonetes próximos. A propagação da luz pelas células de Müller através da retina pode ser considerada como uma parte integral do primeiro passo no processo visual, aumentando a absorção de fótons pelos cones, enquanto afeta minimamente a visão mediada por bastonetes [116].

Uma célula de Müller tem uma parte interna larga, voltada para a pupila, e vai estreitando-se para acoplar em sua parte externa a um único cone. A parte larga do funil fica na frente de aproximadamente 20 bastonetes ao redor do cone (o número de bastonetes próximos aumenta para longe da fóvea). Ver figura 11. 


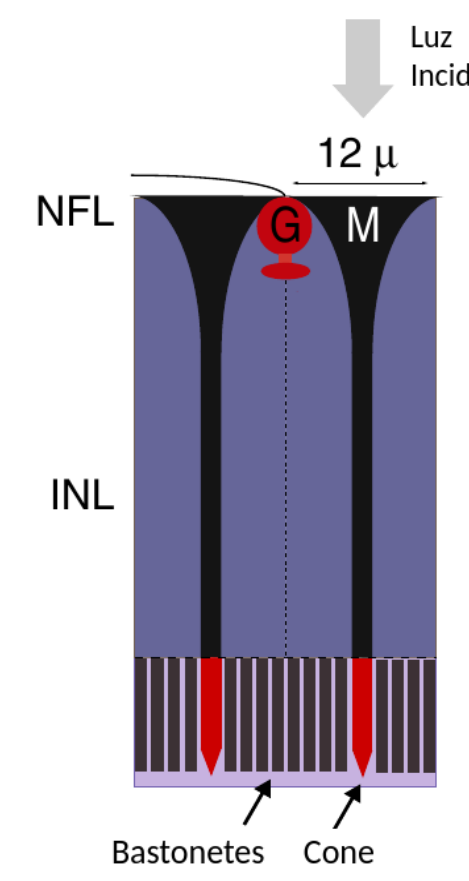

Figura 11: Estrutura célula de Müller

Adaptado de Labin (2014) [116]

\subsubsection{Distribuição}

Depois de receber o estímulo visual e fazer a foto-transdução na retina, a informação comprimida de luminância, crominância, frequência espacial e temporal, entre outras características da imagem é transportada "separadamente" nos diferentes caminhos/sistemas neuronais pelas fibras do nervo óptico. Estas fibras chegarão no mesencéfalo para serem distribuídas nos diferentes centros cerebrais que controlam algumas funções visuais, tais como os movimentos oculares, e posteriormente também ao córtex visual.

\subsubsection{Caminhos neuronais visuais}

Ao sair do olho, os axônios das células ganglionares Parasol, Midget e biestratificadas$\mathrm{K}$ convergem para formar o nervo óptico e continuam juntas mais segregadas formando as vias visuais Magnocelular, formada pelos axônios das GC-Parasol; o Parvocelular, formada pelos axônios das GC-Midget e Koniocelular, formada pelos axônios das GC-K. Assim, o sinal visual é transmitido ao longo do nervo óptico desde o olho até o cérebro. Os dois nervos ópticos, um de cada olho, encontram-se no quiasma óptico e tornam-se os dois tratos ópticos. Cada trato óptico conecta o quiasma óptico ao Corpo Geniculado 
Lateral (ou LGN pelas siglas em inglês). Ver figura 1.

Caminho Magnocelular, Parvocelular e koniocelular Os três tipos de GC melhor caracterizados têm sido associados a caminhos que correm em paralelo e permanecem anatomicamente segregados no LGN e nos compartimentos do córtex visual V1 (ver figura 12). As células ganglionares Midget, Parasol e biestratificadas-K constituem aproximadamente $90 \%$ de todas as células ganglionares da retina de primatas. As GC-Midget são consideradas como sendo a origem do caminho Parvocelular e constituem aproximadamente o $70 \%$ das GC que projetam no LGN. Estas células transmitem os sinais de oponência de cor verde/vermelho ao caminho Parvocelular das camadas do LGN que iráse projetar nas camadas $4 \mathrm{C} \beta$ e 6 da área do córtex visual V1. As células neste caminho possuem pequenos campos receptivos, baixa sensibilidade ao contraste de luminância, velocidade de condução do impulso nervoso baixo (quando comparado com outras GC) e alta sensibilidade a frequências espaciais e baixas frequências temporais, o qual está correlacionado com visão de detalhes e de objetos estáticos [147].

Por outro lado, as GC-Parasol são consideradas como a origem do caminho Magnocelular e constituem aproximadamente um 10\% das GC que projetam no LGN. Estas células transmitem sinais em banda larga e sem oponência de cor às camadas Magnocelulares do LGN que irão para as camadas $4 \mathrm{C} \alpha$ e 6 da área V1 (ver figura 12). As células do caminho Magnocelular em geral possuem campos receptivos largos e extraem informações de uma área 10 vezes maior que as células Midget(por isto respondem melhor a frequências espaciais baixas), possuem alta sensibilidade ao contraste de luminância, e pelos seus axônios estarem bem mielinizados apresentam rápida velocidade de condução de impulsos nervosos e alta sensibilidade a frequências temporais altas. O caminho Magnocelular recebe informação de todos os cones, principalmente verde e vermelho, embora não participem no circuito de percepção de cor (pois não possuem oponência de cor) $[47,173]$. Por isto, possuem alta sensibilidade à luz amarela. O sistema magnocelular é especializado em sincronizar eventos visuais, portanto, em detectar o movimentos. Ele comunica esta informação muito rapidamente ao córtex visual através das camadas magnocelulares do LGN e ao Colículo Superior para o controle reflexo dos movimentos oculares [194]. Consequentemente, pelas características mencionadas anteriormente, o caminho Magnocelular é relacionado com funções tais como percepção de movimento, estereopsis, localização espacial, percepção de profundidade, agrupamento de figuras, percepção de bordas ilusórias, separação figura/fundo. 
Desta forma, os caminhos Magno e Parvocelular mapeiam características diferentes da imagem e levam essa informação até o córtex visual separadamente. Posteriormente, porém, nas camadas mais profundas e mais superficiais do córtex visual primário e nas projeções para a frente dos córtex frontal e parietal, os neurônios magnocelulares e parvocelulares interagem fortemente [198].

Por fim, as pequenas e biestratificadas GC-K compõem parte do caminho Koniocelular e constituem aproximadamente um $8 \%$ das GC que projetam no LGN. Estas células transmitem os sinais de oponência de cor azul-ON amarelo-OFF pelo caminho koniocelular que anda pelas camadas intersticiais do LGN e que irá-se projetar na camada $2 / 3$ nos CO blobs da área V1 do córtex visual. Estudos mostraram também uma forte entrada de bastonetes nas células ganglionares biestratificadas na via KC na retina periférica [30]. As projeções dos axônios koniocelulares não têm sido encontrados só nas camadas koniocelulares do LGN (intercaladas entre as camadas magnocelulares e parvocelulares), mas, também, espalhadas fazendo parte dos caminho parvo e magnocelulares [147]. Assim, as vias koniocelulares estão compostas de um amálgama de células com propriedades diferentes e funções presumivelmente diferentes, incluindo a transmissão de sinais de cones de comprimento de onda curto para o córtex visual [88]. Existem evidências de uma inervação tectal rica nas camadas K do LGN de primatas; o que sugere que esses neurônios podem estar mais intimamente relacionados com as funções do colículo superior, incluindo o controle reflexivo dos movimentos oculares [85]. Além disso, células do sistema koniocelular poderiam estar envolvidas na supressão sacádica (explicação na seção 2.1) através de circuitos que comprometem o colículo superior (SC) e córtex estriado (V1) [43].

A transmissão dos sinais dos cones-S na área V1 podem acontecer através da camada 1 onde os axônios koniocelulares do dLGN contatam dendritos apicais das células da camada 4B ou através dos aferentes koniocelulares que estão dispersos nas áreas interblobs da camada $2 / 3$, que se projetam para a área V2, que por sua vez projetam para a área MT [94]. interblobs

A via koniocelular difere das vias magno e parvo-celular envolvidas na visão consciente. A via koniocelular contém muitos tipos diferentes de células que se projetam difusamente para o córtex superficial e controlam frequências corticais lentas. Em contraste, as vias P e M se projetam topograficamente para o córtex visual primário (V1) e estão ligadas a frequências corticais rápidas. Foi demonstrado que os ritmos koniocelulares lentos modulam as oscilações de alta frequência que fundamentam a percepção cognitiva e influenciam a excitabilidade sensorial, que indicaria que a atividade do Koniocelular pode bloquear 


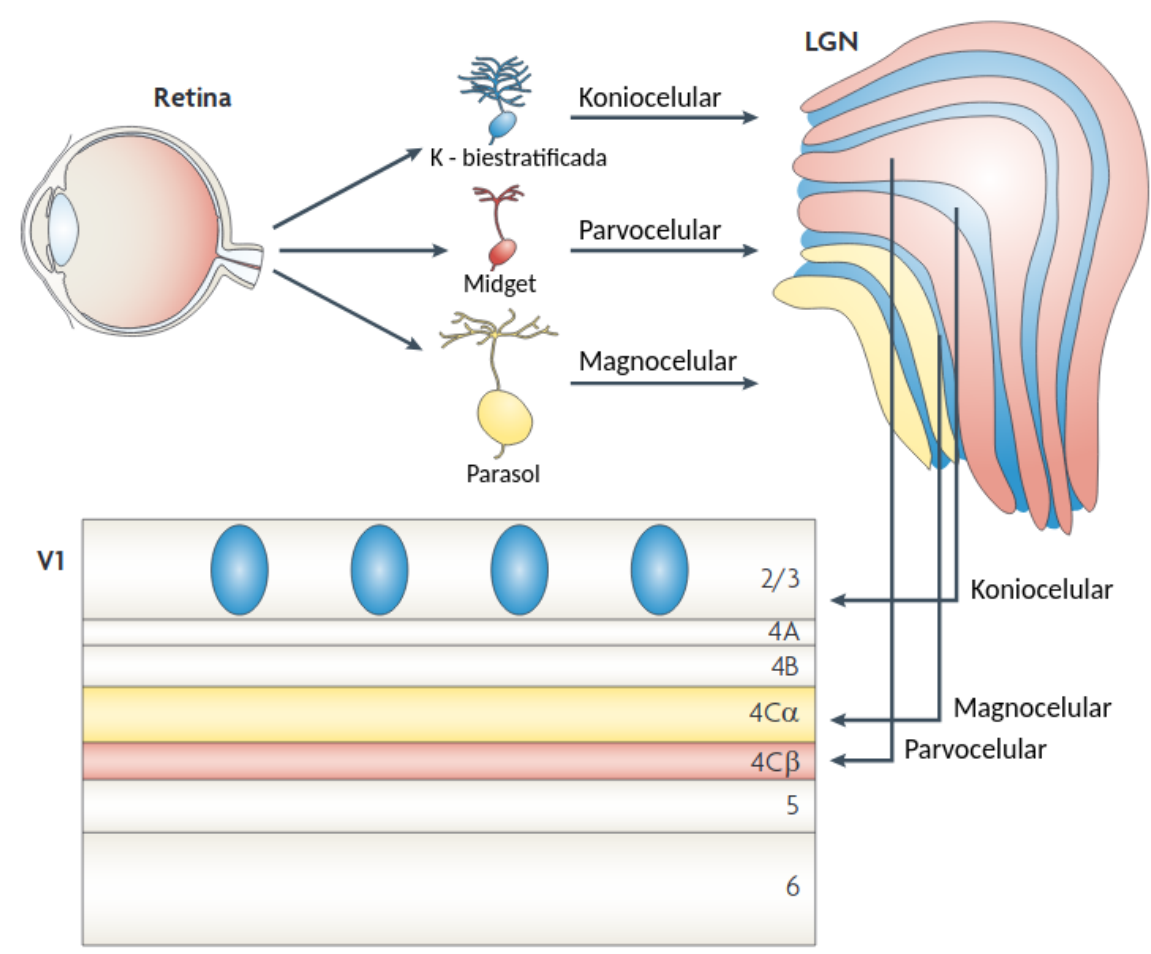

Figura 12: Caminhos visuais Parvocelular, magnocelular e koniocelular que chegam nas áreas do córtex visual primário e são criados a partir dos axônios das GC Midget, Parasol e K, respectivamente.

Fonte: Adaptado de Nassi (2009) [147]

os circuitos corticais derivados de entradas das via Magno e Parvo [118].

\section{Corpo Geniculado Lateral (LGN pelo nome em inglês) e Colículo Superior}

(SC) O corpo geniculado lateral é parte do tálamo, uma estrutura sub-cortical que atua como estação de retransmissão para a informação visual e auditiva. Existe um LGN para cada hemisfério cerebral. Cada LGN possui 6 camadas que recebem informação de cada olho. As camadas 1 e 2 são chamadas de Magnocelulares porque os axônios do caminho Magnocelular projetam-se nela, e a 3, 4, 5 e 6 são chamadas de Parvocelulares. As células ganglionares K são projetadas nas camadas koniocelulares que encontram-se entre as seis principais camadas do LGN. O LGN recebe entrada do sistema de ativação reticular o qual modula a ativação do LGN. Esta área do cérebro controla os níveis de alerta e atenção. Portanto, o nível de ativação dos neurônios do LGN depende de quanta atenção esta colocando o observador. O LGN transmite o estímulo visual entrante ao córtex visual primário ou área V1; este é o caminho geniculado estriado, e é a principal projeção do nervo óptico. Pelo menos $80 \%$ das entradas do LGN são conexões de feedback provenientes da área V1. As figuras 13 e 12 mostram as projeções dos campos visuais direito e esquerdo no LGN. 


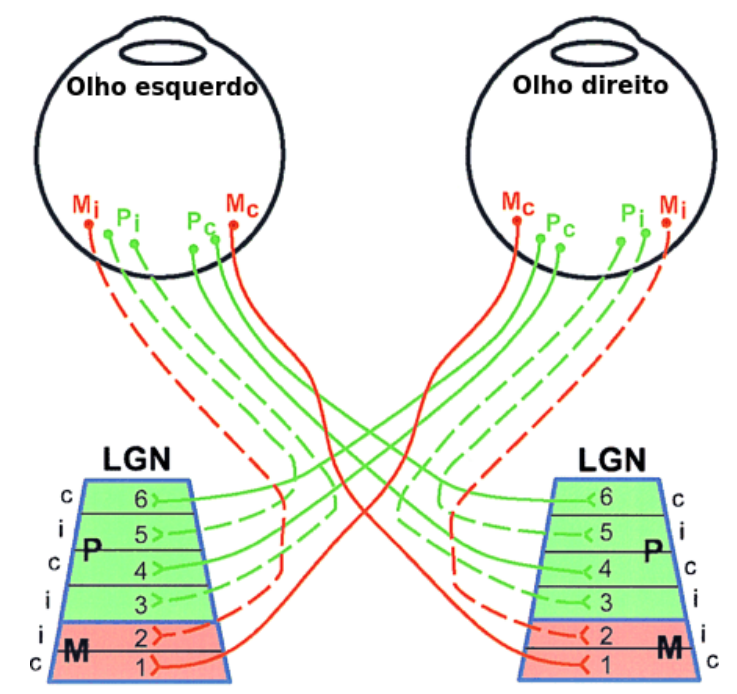

Figura 13: Projeções dos campos visuais direito e esquerdo no LGN.

Fonte: Adaptado de Meissirel (1997) [140]

O nervo óptico também tem uma projeção menor chamada caminho colicular que envia os axônios ao CS. O colículo superior retém o mapa retinotópico ${ }^{1}$ e é responsável por rastrear os movimentos oculares e pela orientação espacial [205]. A maioria da entrada no SC é transmitida pelos axônios das Células ganglionares Parasol que conformam principalmente o caminho Magnocelular, sugerindo que um papel importante desta projeção é dirigir os olhos para estímulos potencialmente relevantes no campo visual. No entanto, como mencionado anteriormente, fibras do caminho Koniocelular também interagem fortemente com o Colículo Superior.

O colículo superior também coordena informações sensoriais, como visão, audição e tato, e detecta movimento no campo visual. A saída do colículo superior vai para os campos oculares frontais (para controlar os movimentos oculares sacádicos), o trato tectospinal (para controlar os movimentos da cabeça) e o pulvinar do tálamo (para ajudar a manter uma visão estável do mundo, mesmo quando a cabeça se move). Depois de deixar o pulvinar, o sinal é projetado de volta ao córtex visual (área MT) para processamento adicional. Também existem conexões para o trato tectopontino que fornece entrada para o cerebelo.

\footnotetext{
${ }^{1}$ mapa neural do campo visual
} 


\subsubsection{Processamento}

A área receptora cortical visual primária está localizada no lobo occipital. Depois que os sinais comprimidos na retina passam pelo LGN e chegam no córtex visual primário, os componentes originais da cena visual devem ser extraídos e integrados numa percepção unificada. O córtex visual usa o processamento hierárquico e modular para atingir essas metas e nas primeiras sinapses corticais da área V1 são extraídas informações novas e mais complexas, como orientação, direção e seletividade de cor [238]. O LGN projeta um mapa retinotópico preciso na área V1. A fóvea ocupa grande parte deste mapa, e isto leva a uma magnificação cortical da fóvea.

\subsubsection{Córtex visual Primário (V1)}

A área V1 recebe projeções e envia sinais de feedback para o LGN, e de saída para a área V2, V3, V4 e a área V5/MT. O córtex visual primário está dividido em 9 camadas (camada 1, camada 2, camada 3, camada 4a, camada 4b, camada 4ca, camada 4cB, camada 5 e camada 6), das quais 6 são funcionalmente distintas. As camadas 1 e 2 são em sua maioria acelulares; ou seja, contêm só axônios e dendritos que projetam em outras áreas do córtex. A camada 4 principalmente recebe projeções neuronais do LGN [205].

Algumas células na área V1 têm a mesma organização centro-periferia que possuem as células ganglionares, mas também existem "células simples" e "células complexas". As células simples respondem a barras claras ou escuras numa determinada orientação e localização, já as células complexas respondem apenas à orientação de uma barra (ignorando a localização). É aqui que começa o processo de abstração de características da cena visual [205].

As células da camada Magnocelular do LGN se projetam na área 4Ca, que por sua vez, se projetam para a camada 4B da área V1. As células na camada 4B têm seletividade de orientação, sensibilidade binocular e são sensíveis à direção do movimento do estímulo. As células da camada Parvocelular do LGN entram na área 4cB que se projetam para as camadas 2 e 3 do V1. As células nas camadas 2 e 3 possuem pequenos campos receptivos e são altamente sensíveis à orientação dos estímulos. Eles também são sensíveis à binocularidade. A informação dos dois olhos começa a se fundir nas camadas 4B e 3, mas os sinais magnocelulares e parvocelulares permanecem segregados. Na camada 3, a via Parvocelular se projeta para duas áreas diferentes: blobs e interblobs. Células blob contêm 
informações de olho único e os interblobs contêm informações de ambos os olhos [124]. As células da camada koniocelular do LGN entra nos blobs corticais da camada 3 do V1. Como visto, a separação do parvo e magnocelular mantém-se no nível do córtex visual primário.

Os Blobs são sensíveis à cor e respondem melhor a baixas frequências espaciais. Estas células não são sensíveis à orientação do estímulo e respondem igualmente a todas as orientações de um estímulo. Os Blobs projetam-se para a área V2. Os Interblobs encontram-se entre as regiões Blob. Os caminhos interblos tanto Magno como Parvocelulares são de orientação seletiva, contendo, cada uma, células que respondem apenas a uma orientação particular do estímulo; seus pequenos campos receptivos tornam as células idealmente adequadas para processar estímulos de alta frequência espacial; estas células são binoculares (integram informações de ambos os olhos) e são relativamente insensíveis à cor. Os Interblobs projetam para as faixas claras da área V2 [205].

\subsubsection{Vias Dorsal e Ventral}

Numa pesquisa feita por Ungerleider e Mishkin em 1982 [209] encontrou-se que lesões na parte inferior do córtex temporal de primatas, levou a deficiências no reconhecimento de objetos, e que lesões no córtex parietal deixou problemas no estímulo de localização. Eles propuseram a existência das vias visuais "What" ou "o que" e "Where" ou "onde". O sistema "What" também chamado via de processamento visual Ventral seria a rota do córtex visual primário occipital ao córtex inferotemporal, ocupado da identificação de objetos; e o sistema "Where" também chamado via de processamento visual dorsal, seria rota do córtex visual primário occipital através da área MT ao córtex posterior parietal, ocupado de reconhecer onde esta o objeto no ambiente.

Foi proposto que o caminho Parvocelular e magnocelular continuariam segregados depois de saírem da área V1 do córtex, formando as vias de processamento visual Ventral e Dorsal, respectivamente. No entanto, Ungerleider [210] sugere que embora tenha sido proposto que as vias ventral e dorsal são extensões dos sistemas de processamento parvo e magnocelular, existe evidência de que não é exatamente assim, e afirma que embora a entrada da via dorsal derive principalmente das células das camadas magnocelulares do LGN, a entrada da via ventral deriva das células de ambos sistemas, o parvo e o magnocelular. Assim, parece que não há um mapeamento 1-para-1 entre os sistemas Magnocelular e Parvocelular e as vias Dorsais e Ventrais. Em vez disso, a via Ventral 
depende tanto da entrada Magnocelular quanto da Parvocelular, enquanto a via Dorsal é dependente principalmente do sistema Magnocelular.

A figura 14 mostra a localização espacial e esquematiza as funções das vias Ventral e Dorsal.

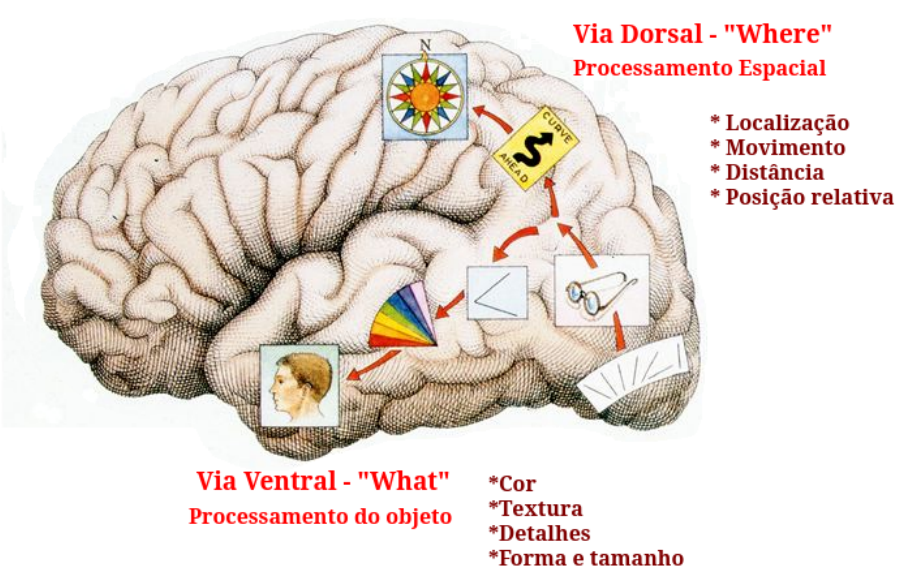

Figura 14: Vias visuais Dorsal e Ventral

Fonte: Adaptado de [13]

Assim sendo, a via Dorsal surge da área V1 e inicialmente se projeta para a área MT (que é responsável por analisar a direção do movimento do estímulo) e a área MST (que é responsável pela percepção do movimento do estímulo e de direcionar os movimentos oculares). A área MT recebe entrada direta da camada 4b do V1 e entrada indireta da área V1 via V2 (blobs e interblobs). Cerca de 90\% das células da área MT mostram sensibilidade à direção do movimento de um estímulo. A via Dorsal termina no lobo parietal posterior, que controla os movimentos que são guiados por estímulos visuais (como alcançar um objeto no ambiente ou os movimentos dos olhos durante a leitura). A via dorsal é importante para localização de objetos e atenção visual.

A via ventral surge da área V1 e se projeta para a área V4 (responsável pelo processamento dos estímulos coloridos e também sensível à orientação, comprimento e largura dos estímulos [238]). A área V4 fornece uma importante contribuição para a área TI (córtex temporal inferior), que é especializada no processamento de arranjos espaciais e é responsável pelo processamento da forma e cor dos estímulos [209]. Estudos concluíram que as regiões da área V1 que dão origem à via de processamento Ventral parecem conter sinais Parvocelulares e Magnocelulares e, portanto, a via Ventral depende tanto dos sinais 
Magnocelulares quanto dos Parvocelulares [205].

Há também algumas evidências de um pequeno envolvimento do Parvocelular nas áreas de detecção de movimento do cérebro [137]. O movimento dos estímulos vermelho e verde é mais difícil de detectar (as células Parvocelulares são centro-periferia vermelho/verde) do que o movimento preto e branco. Ao visualizar estímulos vermelho/verdes, a capacidade de detectar movimentos é prejudicada, mas o movimento ainda pode ser percebido. Isto sugeriria que existe alguma entrada Parvocelular na via Dorsal. Entretanto, uma explicação alternativa é que a via magnocelular é capaz de sinalizar a presença de bordas definidas pelo contraste vermelho/verde [121]. 


\section{MOVIMENTOS OCULARES}

Nesta seção serão descritos os movimentos oculares; seu funcionamento, controle e função em tarefas tais como a leitura. A descrição destes mecanismos é importante, visto que os movimentos oculares erráticos são representativos da população com dificuldade na leitura. Estes movimentos podem ser evidenciados mediante o uso de técnicas de rastreamento ocular, as quais estão sendo amplamente empregadas [76, 82, 105].

\section{$2.1 \quad$ Tipos de movimentos oculares}

Ao ler, olhar uma paisagem, ou procurar um objeto realizamos continuamente movimentos oculares chamados Sacadas. Entre sacada e sacada os olhos permanecem relativamente estáticos, este instante é chamado de fixação. As fixações duram entre 200-300ms dependendo da tarefa em particular. As sacadas são movimentos rápidos dos olhos com velocidades de até $500^{\circ} / \mathrm{s}$. A sensibilidade à entrada de novos estímulos visuais durante a sacada é reduzida; este fenômeno é chamado de Supressão Sacádica. Durante as sacadas então, não se obtêm nova informação, pois os olhos estão se movendo rapidamente através de uma imagem estática que poderia ser percebida como desfocada ou embaçada. Além das sacadas existem outros três tipos de movimentos oculares que devem ser distinguidos: o pursuit, a vergência e os movimentos vestibulares [161].

- Os movimentos de pursuit ocorrem quando os olhos seguem um alvo em movimento, a velocidade destes movimentos é muito mais lenta do que a das sacadas.

- Os movimentos de vergência ocorrem quando os olhos movimentam-se para dentro, um encontrando o outro, com o objetivo de fixar um objeto que esta ficando perto.

- Os movimentos vestibulares acontecem quando os olhos rotacionam-se para compensar os movimentos da cabeça e/ou do corpo, com o objetivo de manter a mesma direção da visão. 
No caso de tarefas que requeiram processamento de informação, os movimentos sacádicos tornam-se mais relevantes.

Existem também, três tipos de pequenos movimentos que devem ser mencionados: nistagmo, drifts e microsacadas. Os olhos realmente nunca estão totalmente estáticos, pois existe um constante tremor dos olhos chamado nistagmo. Tais tremores são normalmente pequenos, e pensa-se que estão relacionados com a atividade perceptual que ajuda às células da retina a manter sua atividade elétrica. Os drifts e as microsacadas tendem a ser movimentos maiores que os nistagmos. Embora a função destes movimentos não esteja completamente explicada, acredita-se que os olhos ocasionalmente fazem drifts por algumas falhas do controle óculo-motor do sistema nervoso. Quando isto acontece, normalmente existe uma microsacada que leva olhos de novo no lugar onde eles estavam.

O campo visual pode ser dividido em três regiões: foveal, parafoveal e periférica. A acuidade visual é muito boa na fóvea (os $2^{\circ}$ centrais da visão), não é tão boa na parafóvea (que estende-se $5^{\circ}$ lateralmente da fóvea) e é fraca na região periférica (região além da parafóvea). Portanto, os olhos movimentam-se para levar à fóvea a parte do estímulo que deseja-se ver claramente. Os estímulos na parafóvea e na periferia influenciam a decisão sobre a ubicação e o inicio da próxima sacada.

\subsection{Movimentos oculares na leitura}

Uma das tarefas mais complexas que o cérebro realiza é a leitura. Uma das partes mais importante deste processo é o movimento harmônico dos olhos através da página, para permitir a codificação do que esta escrito. Tal codificação permite ao cérebro formar um código visual da letra e colocá-la na memória. Na parte da decodificação, os componentes das letras são acessadas e comparadas com as letras na memória, e assim cada letra é lembrada.

Como mencionado, para obter informação visual, os olhos fazem uma série de movimentos rápidos ao longo da página, as Sacadas; e realizam uma pausa para a adquisição da informação visual, as fixações. Na leitura, os olhos devem realizar um deslocamento preciso de uma palavra a outra, assim quando um item é fixado, pode ser processado rapidamente e o próximo movimento pode ser planejado. Isto requer que o movimento de cada olho seja guiado pela informação obtida das regiões periféricas à fixação atual [117].

A quantidade de informação disponível para o cérebro durante uma fixação é chamada 
de perceptual span. Um leitor experiente possui um perceptual span médio de 4 caracteres à esquerda da fixação e 15 caracteres à direita (em idiomas que se leem de esquerda a direita). A informação dos caracteres à direita ajuda a dirigir as sacadas seguintes. Enquanto as áreas centrais da fóvea processam informação para o reconhecimento da palavra, as áreas parafóvicas e periféricas da retina e os seus correspondentes centros cerebrais analisam a forma das letras e o comprimento da informação para ajudar a direcionar futuras sacadas [117].

Na leitura, ao redor do 10-15\% das sacadas são Regressões (movimentos de direita a esquerda ao longo da linha ou movimentos para regressar a linhas anteriores). As sacadas regressivas servem para re-fixar a palavra para fins de uma nova inspeção. Muitas das regressões tendem a ser de poucas letras, e podem ser devidas a que o leitor fez uma sacada muito grande. Regressões muito grandes (mais de 10 letras ou pular de linha) podem ocorrer porque o leitor não teve uma boa compreensão do conteúdo da leitura.

Existe uma grande variabilidade entre a duração da fixação, o comprimento da sacada e a frequência das regressões. Na figura 15 são ilustradas a distribuição de frequência da duração das fixações e do comprimento da sacada.
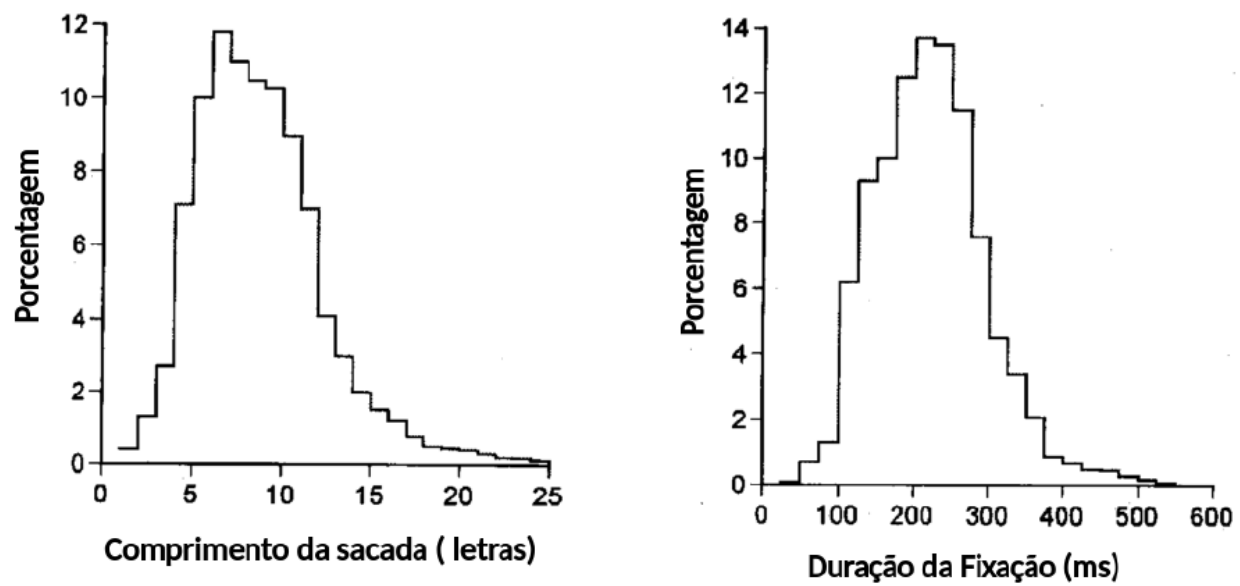

Figura 15: Distribuições de frequência da duração da fixação e dos comprimentos da sacada. A duração das fixações está em milisegundos e o comprimento das sacadas esta em número de caracteres.

Fonte: Adaptado de Rayner (1998) [161]

Este tipo de movimentos oculares também são influenciados por variáveis textuais e topográficas. Por exemplo, quando o texto é conceptualmente mais difícil, o tempo de fixação incrementa, o comprimento da sacada decrementa e a frequência das regressões aumenta. Bons leitores tendem a ajustar a amplitude da sacada de acordo com a amplitude da palavra, aumentando a velocidade da leitura. Em leitores deficientes, essa capacidade foi encontrada limitada em palavras com mais de cinco letras [132]. A frequência da pa- 
lavra é determinada pela contagem de sua ocorrência na forma impressa de determinada língua. Assim, palavras de alta frequência são aquelas com alto índice de ocorrência, sendo mais familiares aos leitores. A maior familiaridade com a palavra, assim como a maior previsibilidade contextual, leva à diminuição na duração e no número de fixações. [161]. A imagem 16 mostra um esquema de uma curva de leitura onde são representadas as sacadas, fixações, regressões e saltos de linha.

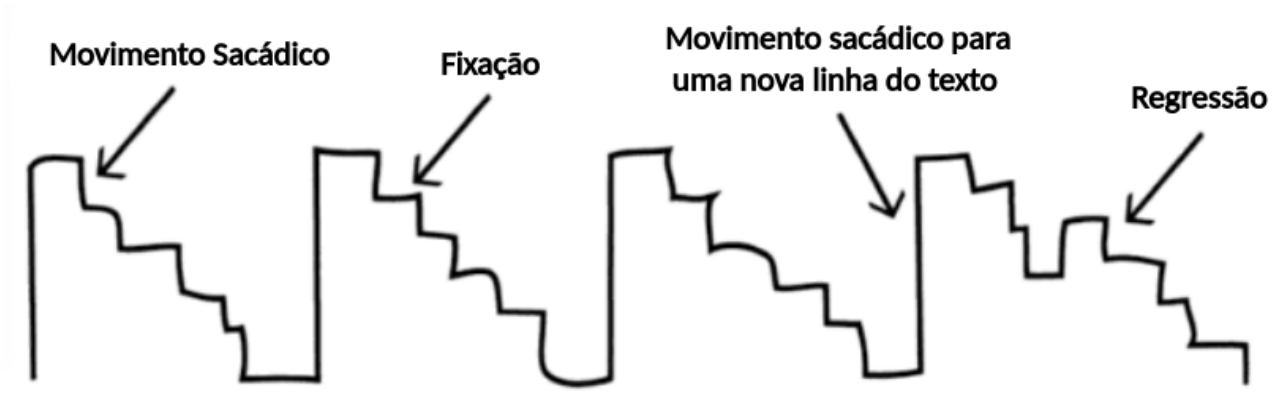

Figura 16: Esquema de uma curva de leitura. Adaptado de [117]

Fonte: Adaptado de Lane (2005) [117]

Para saber quão longe os olhos têm que se deslocar para a próxima fixação o cérebro utiliza uma combinação entre a informação visual periférica e o conhecimento dos padrões da linguagem. O ponto mais provável para centrar a fixação é perto do centro da palavra. De fato, este lugar tende a ser entre a metade e o começo da palavra. A fixação tem menos probabilidade de ocorrer nos artigos e nos espaços em branco [117].

Durante a fixação o cérebro esta ocupado não só codificando a informação, mas também decidindo onde mover os olhos para realizar a próxima fixação. A figura 17 dá uma ideia do que acontece durante uma fixação que dura 250ms. A maioria da informação visual necessária para ler é adquirida ao redor dos primeiros $50 \mathrm{~ms}$ da fixação, deixando os 200 ms restantes para completar a programação do próximo movimento ocular e para realizar um processamento linguístico de mais alto nível. O processamento da informação fornecida durante a fixação não é completado ao final da fixação, e o início da próxima fixação não é desencadeado pela conclusão do processamento de tal informação. Aspectos da linguagem do texto devem ter a sua influencia no processamento dentro dos seguintes $100 \mathrm{~ms}$ depois do começo da fixação, isto é chamado de Limiar de influencia textual. Ao redor dos 10 ms tem-se uma ideia de quando a próxima sacada vai começar, e depois de 100 ms mais, mudanças no estímulo visual não irão afetar quando a próxima sacada irá começar; isto é chamado de deadline da sacada. $30 \mathrm{~ms}$ antes do início da próxima sacada é o momento no qual os centros do cérebro estão totalmente comprometidos com o tempo da próxima sacada; este instante é chamado de ponto de não retorno [117]. 
Fixaçāo

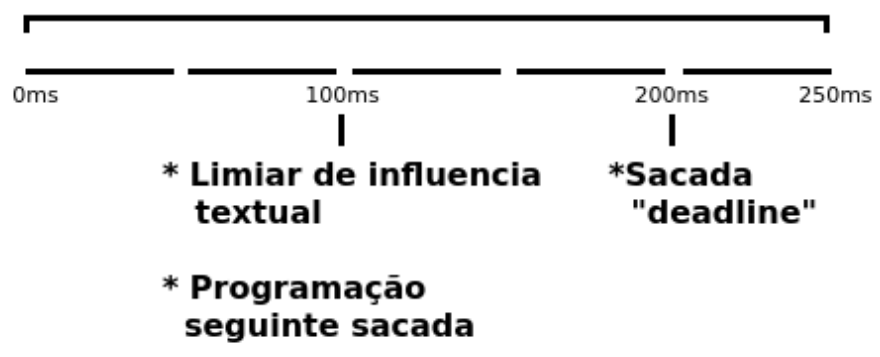

Fixaçāo

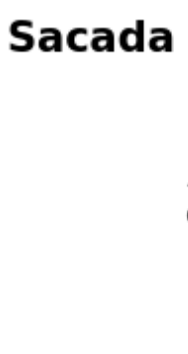

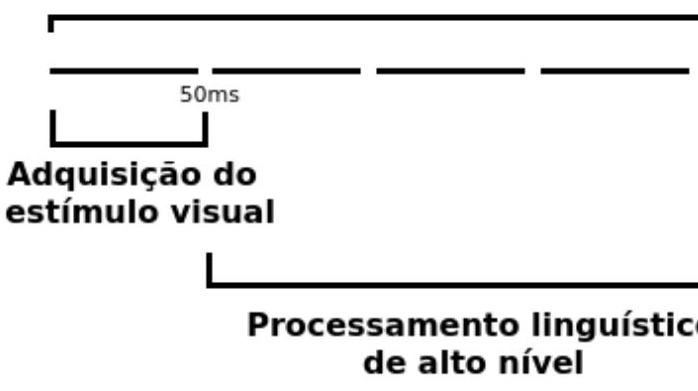

Figura 17: Esquema do processamento visual em cada fixação

Fonte: própria

Leitores deficientes (ou com dificuldades na leitura), disléxicos, assim como leitores iniciantes realizam fixações longas, sacadas curtas, mais fixações e mais regressões que os leitores normais [117]. Assim também o perceptual span ou região efetiva de visão durante a fixação é maior em leitores rápidos que em leitores lentos [163]. Certamente, pessoas com pouca visão, ou com distúrbios óculo-motores, como forte nistagmo ou intrusões na sacada, possuem dificuldades para ler. No entanto, se os movimentos oculares fossem um fator causante na dificuldade na leitura, o problema poderia ser facilmente diagnosticado com um teste simples; e um treinamento do sistema óculo-motor poderia resultar numa melhoria na leitura.

Embora tenha sido demonstrado que efetivamente é possível melhorar a leitura com treinamento do sistema óculo-motor, Rayner [161] argumenta que geralmente os movimentos oculares erráticos não são a causa da dificuldade na leitura, mas são o reflexo de problemas mais profundos. Na figura 18 observa-se uma curva de leitura de uma criança com dificuldades na leitura. Observe o número excessivo de regressões.

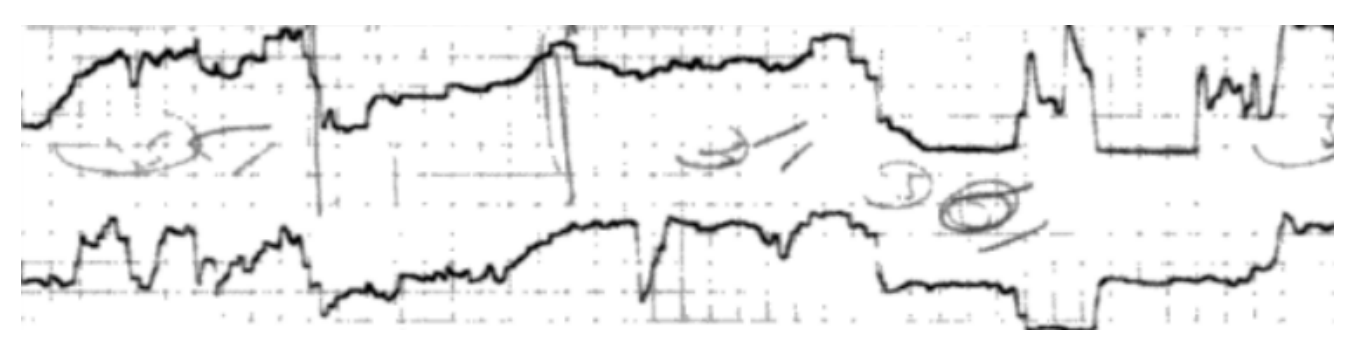

Figura 18: Curva de leitura de uma criança com dificuldade na leitura. [117]

Fonte: Adaptado de Lane (2005) [117]

Num estudo feito com eye-tracker em crianças que apresentaram baixa e alta pon- 
tuação nas provas de leitura PISA [112] mostrou que a diferença principal no padrão de leitura que caracteriza um indivíduo com deficiência na leitura são as sacadas mais curtas e que parâmetros tais como porcentagem de regressões e velocidade de leitura têm variabilidade mais ampla entre estudantes de baixa pontuação, indicando que o controle ocular destas pessoas funciona de formas diferentes ao analisar o mesmo texto.

\subsection{Circuitos neuronais na leitura}

Breitmeyer [36] propôs que a via magnocelular direciona o olho para a posição de interesse no campo visual e, em seguida, a via Parvocelular extrai a representação detalhada daquela parte do campo visual, uma vez que é diretamente fixada pela fóvea. Outros autores formularam a hipótese que o sistema magnocelular poderia ter um papel importante no próprio processamento das palavras.

Existe evidência de que algum processamento léxico ocorre antes que a fóvea fixe a palavra. Por exemplo, nem todas as palavras da frase são fixadas. Aproximadamente um terço das palavras em uma sentença é ignorado. Ao redor de $80 \%$ das palavras de uma única letra são ignoradas [205]. Palavras que são ignoradas não recebem uma fixação direta. Isso implica que um nível suficiente de processamento da palavra já foi alcançado e que não são necessárias fixações adicionais (foveais). Uma possível explicação para este evento é que o suficiente da palavra caiu dentro da visão foveal para que essa palavra seja processada. No entanto, há evidências que sugerem que na pré-visualização parafoveal ocorre algum processamento de palavras; e já que as células ganglionares que compõem o sistema Magnocelular são as mais comuns na parafóvea, foi proposto que o caminho Magnocelular é o responsável por esses efeitos de pré-reconhecimento da palavra.

Quando uma palavra é apresentada à visão parafoveal antes que a fixação foveal aconteça ela é processada mais rapidamente depois que é fixada, mas quando é fixada sem ter sido visualizada previamente na parafóvea o processamento fica mais lento. $\mathrm{Cu}$ riosamente, se a palavra é apresentada à parafóvea, em letras maiores do que as que são normalmente usadas em texto impresso, todo o processamento da palavra pode ser alcançado no preview parafoveal [161]. Isso é consistente com o fato de que as células ganglionares magnocelulares têm grandes campos receptivos e, assim, estímulos maiores são mais facilmente reconhecidos do que pequenos.

O preview parafoveal pode ajudar, então, a estimar onde fixar o olhar na próxima 
sentença e também pode ser usado para facilitar o reconhecimento de palavras que devem ser fixadas. Isto, seria mediado pelo sistema Magnocelular [205]. Algumas pesquisas mostraram que informação fonológica e ortográfica é extraída do preview parafoveal. Rayner et al. [162] concluíram que leitores deficientes não pareciam obter todos os benefícios da pré-visualização na parafóvea, pois tinham uma capacidade menor de utilizar a informação ortográfica ao seu favor.

Ao aprender a ler, os indivíduos dependem do processamento da via dorsal. A via dorsal está associada ao mapeamento de unidades ortográficas sub-lexicais em fonemas individuais e à integração de representações ortográficas e sonoras. É somente quando a habilidade de leitura se desenvolve que o processamento da via ventral começa a contribuir para o reconhecimento de palavras. Este fluxo de processamento é mais rápido e permite que as palavras sejam reconhecidas como unidades inteiras, uma vez estabelecidas na memória léxica.

Desta forma então, num modelo de leitura baseado no processamento sequencial, o sistema Magnocelular seria responsável pela primeira identificação ortográfica, sendo sensível às baixas frequências espaciais, portanto, capaz uma análise global; o segundo estágio seria o processamento de detalhes, por meio da resolução de frequências espaciais mais altas realizadas pelo sistema Parvocelular [16]. A identificação ortográfica mediada pelo Magno seria o primeiro estágio de leitura, uma vez que a transmissão da informação é mais rápida ao longo da rede magnocelular em comparação com a via Parvocelular. Assim, o Magno fornece uma pré-visão (preview, no Inglês) de baixa frequência espacial que pode ser usada para identificação ortográfica. Se houver informação suficiente disponível, as palavras são identificadas rapidamente com base apenas na informação do Magno. Quando o sistema ortográfico não consegue identificar uma palavra, deve-se aguardar por mais informações detalhadas a partir do sistema Parvocelular.

\subsubsection{Persistência visual}

Estudos mostraram que, depois de apresentar um estímulo visual, o estímulo continua sendo "visto" por algum tempo, e este efeito pode durar até $300 \mathrm{~ms}$ [130]. Portanto, na leitura de um indivíduo normal o cérebro não permite que a imagem adquirida numa fixação continue sendo vista na seguinte fixação; pois se duas entradas visuais individuais pudessem ser vistas ao mesmo tempo, não se saberia de qual fixação é a primeira ou a seguinte. Para superar esta questão, o sistema Magnocelular e Parvocelular operam em 
paralelo desde a retina até o córtex visual.

As imagens na retina são amostradas duas vezes pelo sistema visual, pela visão periférica para obter uma visão geral do objeto ou palavra (realizado pelo Magnocelular), e pela visão central para obter os detalhes finos da cena (realizado pelo Parvocelular). No decorrer da fixação acontece a codificação e decodificação da palavra. A informação cognitiva é mantida no subconsciente para ajudar na identificação das palavras e na compreensão de leitura. Quando os olhos se deslocam de uma fixação para outra mediante os movimentos sacádicos, a informação cognitiva continua; no entanto, a informação visual estaria terminada pela estimulação do sistema Magnocelular. Caso esta supressão de informação entre fixação e fixação não aconteça pode-se produzir um fenômeno conhecido como Persistência visual, no qual a informação visual de uma fixação intercepta a informação da seguinte fixação gerando uma sobreposição de imagens. Uma deficiência que afete a sincronização dos sistemas transiente (Magno) e contínuo (Parvo) poderia interferir com o processamento de fixações consecutivas, deixando uma superposição de imagens consecutivas [187]. Efeitos como este são relatados como visões de algumas crianças com dificuldades na leitura [92]. 


\section{ESTRESSE VISUAL OU SÍNDROME DE IRLEN}

Nesta seção será caracterizado o tema desta pesquisa, uma condição visual. Na área pedagógica é comumente chamada Síndrome de Irlen, no entanto, desde sua descrição em 1985 pela professora Olive Meares na Nova Zelândia e posteriormente pela psicóloga estado-unidense Helen Irlen, várias pesquisas caracterizam os indivíduos que possuem esta condição como portadores da Síndrome de Irlen, Síndrome de Meares-Irlen, Síndrome de Sensibilidade Escotópica, Estresse Visual, Estresse Visual Relacionada aos Padrões Listrados (PRVS - Pattern Related Visual Stress) ou simplesmente como pessoas com dificuldade na leitura (o que amplia muito a quantidade de pessoas que apresentariam esta condição). O termo Estresse Visual é amplamente usado por pesquisadores do Reino Unido e, atualmente, é o mais aceito na área científica para caracterizar este conjunto de sintomas e sinais. Assim, neste capítulo, irão ser apresentados os principais sintomas, diagnóstico, tratamento e as principais hipóteses sobre a etiologia do EV ou SI (ao longo do texto os dois termos serão utilizados para se referir ao mesmo conjunto de sintomas).

Uma síndrome é um grupo de sinais e sintomas que ocorrem juntos e caracterizam uma anormalidade particular. A síndrome de Irlen foi reportada pela primeira vez como uma série de distorções visuais e sintomas de astenopia apresentadas na hora da leitura; e que tais distorções podiam ser reduzidas através de lâminas plásticas que filtram comprimentos de onda da luz visível chamadas "overlays". No seu livro "Reading by the colors", Irlen descreve como foi feita a descoberta da síndrome e apresenta alguns casos. Na primeira versão deste livro em 1991, Irlen declara que esta condição afeta de 12-14\% da população geral e $46 \%$ da população com dislexia [92]. Em 2005, Kriss e Evans apresentam estudos onde mostraram que crianças com dislexia parecem se beneficiar mais dos filtros espectrais que crianças não disléxicas [111].

A síndrome de Irlen pode afetar adultos e crianças, manifestando-se em diferentes formas e intensidades para cada indivíduo, interferindo com o desempenho acadêmico e 
laboral dos sujeitos, afetando a atenção, a concentração, o comportamento (por exemplo, irritabilidade e incapacidade de ficar unicamente num lugar), entre outros [81].

\subsection{Sintomas}

O EV esta caracterizado principalmente pela percepção de distorções visuais quando são observados padrões listrados, tais como o texto. As distorções podem ocorrer apesar da ausência de anormalidades oftalmológicas e/ou optométricas [68,194]. Autores sugerem que o EV não esta relacionado com problemas optométricos regulares, embora anomalias binoculares ou acomodativas possam acontecer em conjunto com a Síndrome [68,172,181, 224]. Idealmente, os estudos nesta área devem ter o cuidado de desconsiderar qualquer tipo de anormalidade optométrica ou acomodativa no grupo de pesquisa.

Existem vários sintomas e sinais que são utilizados para detectar alguma irregularidade no comportamento do indivíduo com EV. Frequentemente são notadas por pessoas próximas, como parentes ou professores. Como mencionado, esta condição visual pode ocorrer em pessoas de qualquer faixa etária; no entanto, é descoberta principalmente em crianças em idade escolar, pois a dificuldade na leitura sobressai nestas pessoas. Em adultos o EV é normalmente diagnósticado depois que alguém do círculo social próximo foi diagnosticado (por exemplo, pais depois que os filhos foram diagnosticados).

A seguir são enunciados os principais sinais e sintomas que se manifestam no EV.

\subsubsection{Dificuldades na leitura}

A Dificuldade na leitura é o sintoma mais pesquisado na literatura, pois é facilmente notado e existem testes que podem avaliar seu desempenho antes e depois de alguma intervenção terapêutica (WRRT -Wilkins Read Rate Test- [228] ou Eye-tracking). Alguns sinais exibidos durante a leitura podem sugerir a presença do EV, por exemplo:

- Leitura silábica (inapropriada para o nível de desenvolvimento da leitura na faixa etária)

- Compreensão de leitura fraca ou insuficiente (inapropriada para o nível de desenvolvimento da leitura na faixa etária)

- Problemas seguindo a linha de leitura 
- Pular palavras ou linhas no texto

- Ler devagar ou hesitantemente

- Fazer pausas constantes e em intervalos frequentes

- Evitar ler

- Preferência por ler com pouca luz

Em alguns indivíduos mais treinados na leitura, por exemplo, adultos que se adaptaram a esta condição visual, a leitura pode ter velocidade normal, no entanto, a fadiga ocular e outros sintomas do EV podem chegar rapidamente.

\subsubsection{Problemas na escrita}

Problemas para perceber a orientação das linhas no caderno, escritas e sem escrever, poderiam ser efeitos ocasionados pelas distorções visuais geradas nas pessoas com EV; o que produziria:

- Letra pouco legível

- Inadequado espaçamento das letras e/ou palavras

- Inadequado tamanho das letras

- Escritura por cima e/ou por baixo la linha

- Soletração inconsistente

Os indivíduos com EV podem apresentar dificuldades para escrever, levando tempo em reconhecer as letras e escrevê-las. As letras podem ter um formato confuso e ter um espaçamento inadequado. As palavras podem ser posicionadas num eixo curvo, simulando a distorção que se está enxergando.

\subsubsection{Desconforto visual}

O desconforto visual pode se manifestar como 
- fadiga ocular,

- cansaço ou sonolência,

- dores de cabeça ou náuseas,

- olhos que doem ou ficam lacrimejantes e

- inquietação.

Estes sinais podem acontecer numa variedade de condições visuais, portanto, para serem considerados como parte do EV estes devem se apresentar em conjunto com outros

sintomas. É possível que os sinais descritos sejam consequência das distorções vistas pelo indivíduo, pois quando o objeto que se está observando, neste caso as palavras no texto, não se apresentam de forma clara, e a pessoa precisa fazer um esforço extra para ler.

\subsubsection{Sensibilidade à luz ou fotofobia}

Alguns indivíduos se incomodam muito com o brilho, as luzes fluorescentes e até com a luz do dia. Na leitura, estes optam por fazer uso de estratégias tais como

- dar preferência por lugares com baixa luminosidade;

- fazem uso de implementos tais como bonés ou chapéus para criar sombra na superfície que estão tentando ler, inclusive podem fazer sombra no texto com o próprio corpo;

- preferem o contraste fundo preto-letra branca;

- diminuem a luminosidade dos aparelhos eletrônicos tais como tablets, celulares e/ou computadores.

Esta sensibilidade, quando não for possível evitar a luz, pode resultar em irritabilidade, cansaço, dores de cabeça, mudanças de humor, ansiedade, pouca concentração, entre outros. 


\subsubsection{Problemas de atenção e concentração}

Dificuldades na concentração na leitura ou na realização alguma tarefa acadêmica pode ser decorrente da incapacidade de perceber o texto adequadamente ou requerer muito esforço visual para realizar as tarefas.

\subsubsection{Percepção de profundidade diminuída}

Este é um sintoma que pode ser facilmente confundido com uma "falta de jeito", mas quando combinado com outros sintomas como dificuldades na leitura, passa a ser um indicador de que pode ser necessário algum tratamento. A percepção de profundidade diminuída pode se manifestar como

- dificuldade em realizar atividades esportivas, como por exemplo agarrar uma bola que esta vindo;

- dificuldades em julgar distâncias;

- bater em cantos e móveis com frequência.

\subsubsection{Distorções visuais na leitura}

Um estudo feito com o método Delphi ${ }^{1}$ mostrou que os especialistas em diagnosticar EV no Reino Unido consideram que mencionar pelo menos três das distorções visuais (especialmente as letras se mexendo no texto) em conjunto com pelo menos dois sinais (mencionados no parágrafo sinais 3.3.5), indicaria a presença da síndrome [72].

As pessoas com EV relatam ver que as palavras na página parecem ter pouca clareza ou instabilidades; ou seja, parecem embaçadas ou desfocadas, movimentando-se ou desaparecendo. As distorções relatadas por pessoas com a síndrome são mostradas nas figuras 19 à 28.

As distorções mostradas anteriormente são as mais conhecidas e divulgadas, no entanto e muito possível que pessoas com esta síndrome possam experimentar variações delas ou inclusive alguma diferente.

\footnotetext{
${ }^{1}$ O Método Delphi tem como objetivo obter o consenso da opinião de grupo de especialistas de forma objetiva por meio de uma série de questionamentos e feedback sobre eventos futuros. [133]
} 


\begin{abstract}
HALO

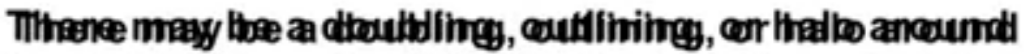

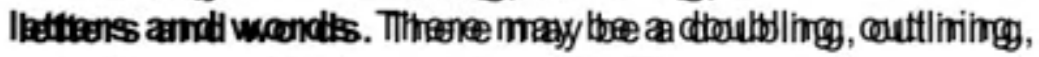

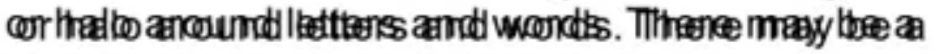

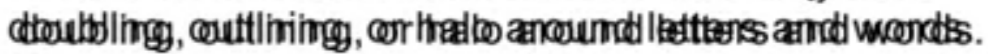

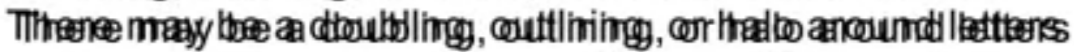

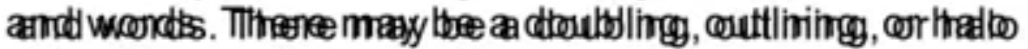

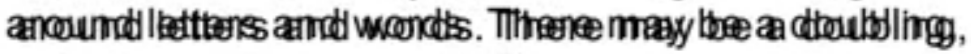

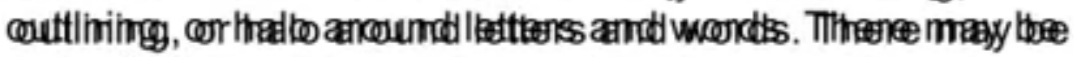

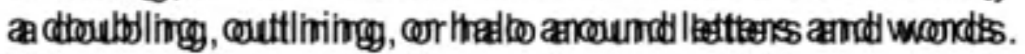

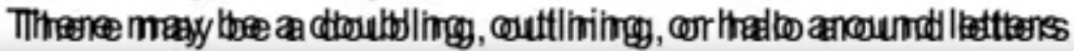

Figura 19: Distorção Halo. As letras ou palavras podem parecer com brilho no fundo ou ter bordas grossas. Podem aparecer também duplicadas

Fonte: Adaptado de [5]

\title{
BLURRY
}

Words on the page can appear blurry or fuzzy. Words on the page can appear blurry or fuzzy. Words on the page can appear blurry or fuzzy. Words on the page can appear blurry or fuzzy. Words on the page can appear blurry or fuzzy. Words on the page can appear blurry or fuzzy. Words on the page can appear blurry or fuzzy. Words on the page can appear blurry or fuzzy. Words on the page can appear blurry or fuzzy. Words on the page can appear blurry or fuzzy. Words on the page can appear blurry or fuzzy. Words on the page can appear

Figura 20: Distorção Blurry. As letras e/ou palavras no texto podem parecer desfocadas ou difusas Fonte: Adaptado de [5]

Num estudo feito por Evans et al. foi avaliada a prevalência de alguma(s) distorções. Reportaram que $24 \%$ dos sujeitos avaliados tinha principalmente visão embaçada/desfocada (blurring), $16 \%$ visão dupla, $12 \%$ via letras pulando da folha de texto, $6 \%$ enxergava mudança no formato da letra e $3.5 \%$ apresentava o desvanecimento do estímulo visual.

\subsection{Tratamento}

Segundo Irlen [92] os sintomas mencionados anteriormente podem ser tratados através de lâminas ou lentes coloridas que filtram alguns comprimentos de ondas do espectro da luz visível, sendo que cada pessoa possui uma cor ótima de filtro para ela $[92,219]$. 


\section{FLOATING}

\section{Letters and words may float up off the page or} appear to get 3-D. Letters and words may float up off the page or appear to get 3-D. Letters and words may float up off the page or appear to get 3-D. Letters and words may float up off the page or appear to get 3-D. Letters and words may float up off the page or appear to get 3-D. Letters and words may float up off the page or appear to get 3-D. Letters and words may float up off the page or appear to get 3-D. Letters and words may float up off the page or appear to get 3-D. Letters and words may float

Figura 21: Distorção Floating. As palavras no texto podem parecer flutuando, saindo da página ou com um efeito 3D

Fonte: Adaptado de [5]

\section{RIVERS}

Words and letters may run together on the page, creating trails of white space flowing down the page like rivers. Words and letters may run together on the page, creating trails of white space flowing down the page like rivers. Words and letters may run together on the page, creating trails of white space flowing down the page like rivers. Words and letters may run together on the page, creating trails of white space flowing down the page like rivers. Words and letters may run together on the page, creating trails of white space flowing down the

Figura 22: Distorção Rivers. As letras ou palavras podem juntar-se criando trilhas de espaços em branco parecendo um fluxo na página

Fonte: Adaptado de [5]

As overlays são lâminas coloridas translúcidas que têm mostrado ser eficazes para aliviar os sintomas da SI. Vários estudos, incluindo alguns com o efeito placebo controlado, têm mostrado que os filtros espectrais possuem efeitos benéficos na leitura $[28,42,62,84,87$, 89,95,160,168,180,188,203,213,219,222]. Estes são colocados encima do texto, mudando assim, o contraste e a cor do fundo. O efeito de filtrar o espectro de luz visível também pode ser obtido colocando nos óculos uma película colorida que filtra os comprimentos de onda específicos de cada indivíduo. Estes filtros podem ser aplicados sobre as lentes de óculos de grau. Na figura 29 podem ser vistos as overlays e as lentes.

A seguir serão detalhados os dois tipos de filtros espectrais. 


\section{RIPPLE}

\section{Lines of print may have a subtle ripple instead of} being straight and flat. Lines of print may have a subtle ripple instead of being straight and flat. Lines of print may have a subtle ripple instead of being straight and flat. Lines of print may have a subtle ripple instead of being straight and flat. Lines of print may have a subtle ripple instead of being straight and flat. Lines of print may have a subtle ripple instead of being straight and flat. Lines of print may have a subtle ripple instead of being straight and flat. Lines of print may have a subtle ripple instead of

Figura 23: Distorção Ripple. As letras ou palavras podem parecer com ondulações em lugar de serem retas e planas

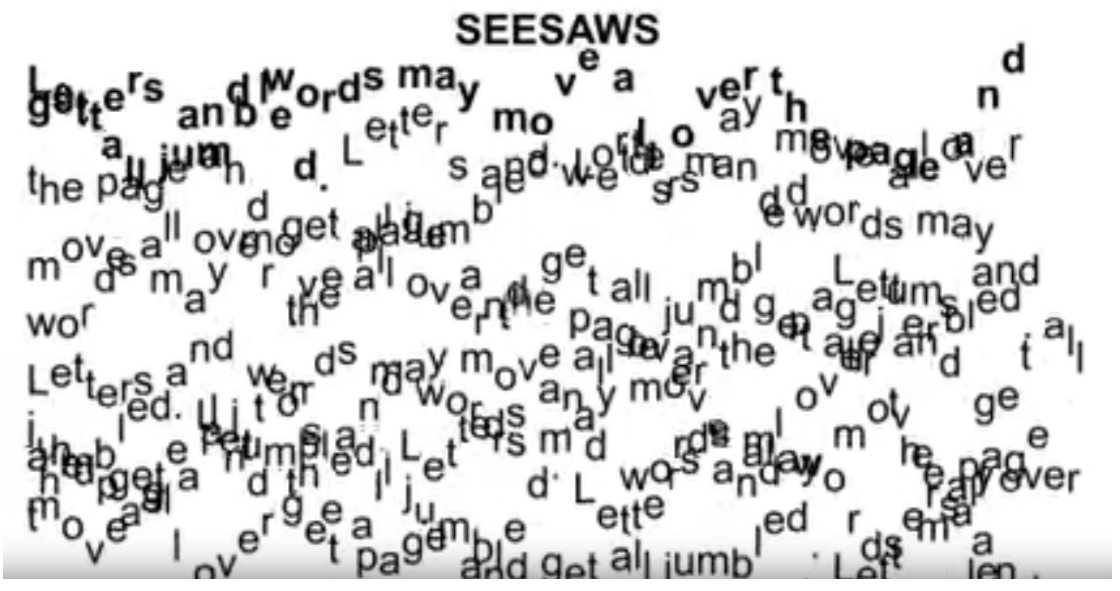

Figura 24: Distorção Seesaw. As letras ou palavras podem-se mover pela página toda e ficarem embaralhadas e confusas

\section{Fonte: Adaptado de [5]}

\subsubsection{Overlays}

Atualmente, as overlays vêm em 10 cores diferentes: grey, yellow, lime, green, mint green, aqua, blue, purple, pink, rose e orange. Na figura 30 mostram-se as suas cromaticidades e curva de transmitância. E na imagem 29 podem ser vistos na realidade. As overlays podem ser colocadas uma sobre outra modificando as cores que podem ser transmitidas. A lâmina colorida possui um lado brilhante o outro fosco para reduzir as reflexões da luz, no entanto, quando superpostas, podem reduzir a claridade do fundo do texto.

Alguns autores argumentam que para cada indivíduo existe uma cor ótima que repre- 


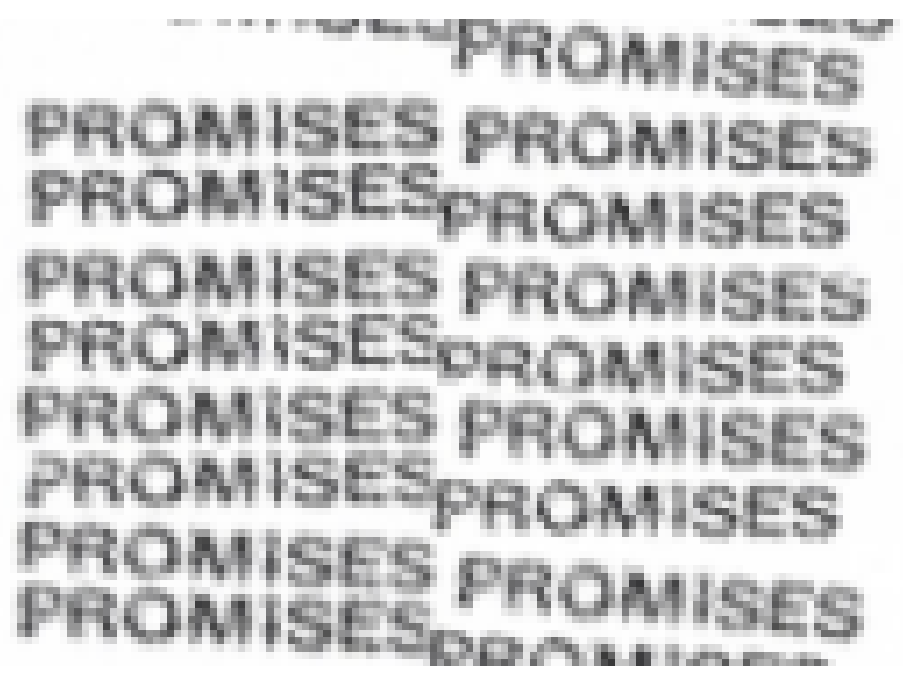

Figura 25: Distorção Shaky. As letras ou palavras podem parecer que se mexem de lado a lado ou de cima pra baixo

Fonte: Adaptado de [5]

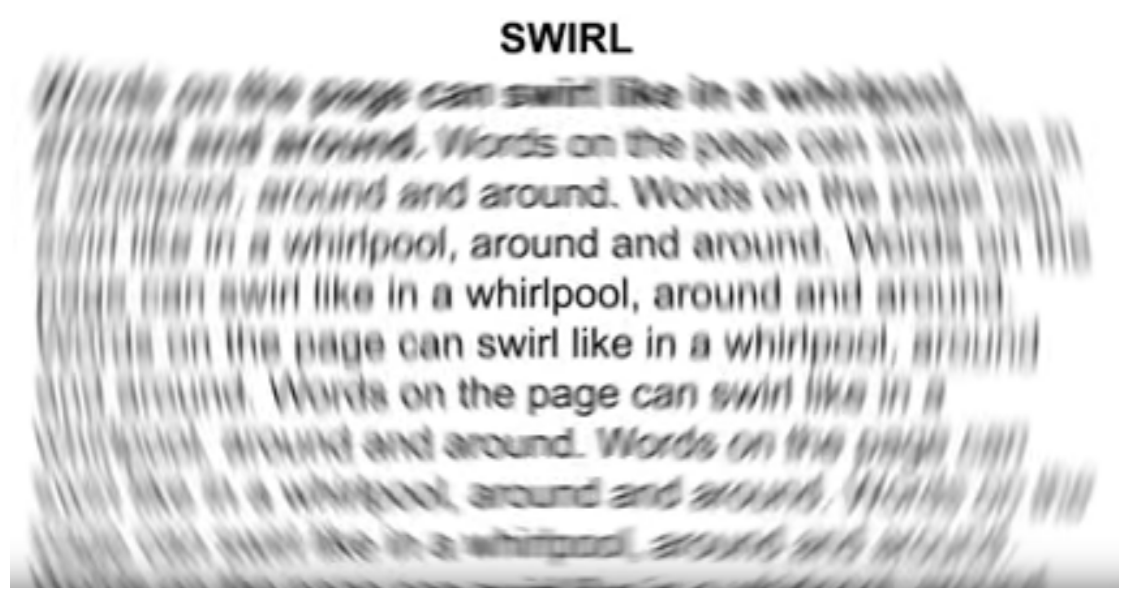

Figura 26: Distorção Swirl. As letras ou palavras podem parecer que se mexem como num redemoinho deixando só o foco estático

Fonte: Adaptado de [5]

senta a tonalidade mais benéfica para reduzir os sintomas do EV e melhorar o processo de leitura [227]. No entanto, alguns outros argumentam que unicamente com filtros azuis e amarelos o benefício dos filtros espectrais ainda estaria presente [198].

O filtro (cor) ótimo nas overlays, normalmente não é o mesmo que deve ser aplicado nas lentes [123]. Quando uma overlay é utilizada, os olhos adaptam-se à luz do ambiente, enquanto com óculos todo o campo visual é colorido de acordo com a cor da lente. Iniciase um processo de adaptação cerebral no qual a pessoa se ajusta às novas condições de cor e consegue distinguir normalmente as cores, ocorre a constância de cor [216]. 


\section{STAR WARS}

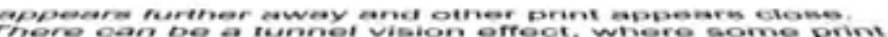
appears further away and other print appesars chose. rhere cen be a lummel vision efrect, where some orin sposers hurtior away and otwer print appears dons There

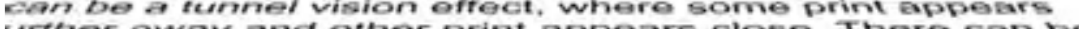

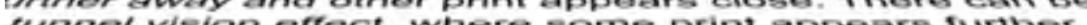
runnel vision ofrect. Where some print appears runtwer wy and other print appears close. There can be a nol vision effect, where some print appears further $y$ and other print appears close. There can be a if vision effect, where some print appears further and other print appears close. There can be a vision effect, where some print appears furthe id other print appears close. There can be a sion effect, where some print appears furt lother print appears close. There can be no affont whorn onma nrint anmonref..

Figura 27: Distorção Starwars. As linhas do texto podem parecer em perspectiva com um efeito túnel onde algumas linhas podem parecer mais longe e outras mais perto

Fonte: Adaptado de [5]

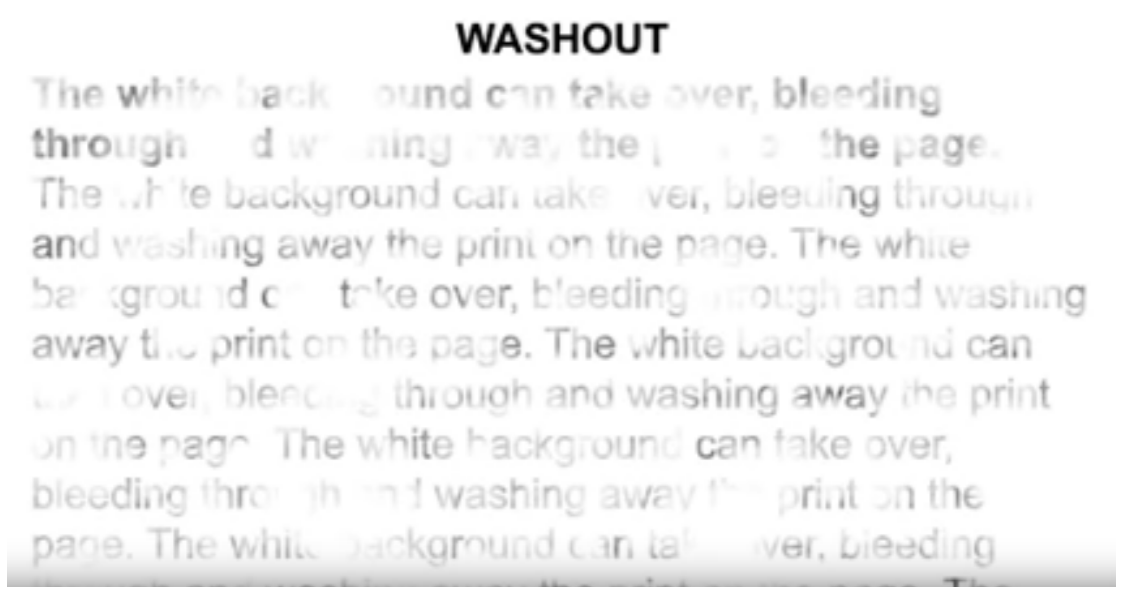

Figura 28: Distorção Washout. O texto pode parecer com partes lavadas ou ficar difuso por partes

Fonte: Adaptado de [5]

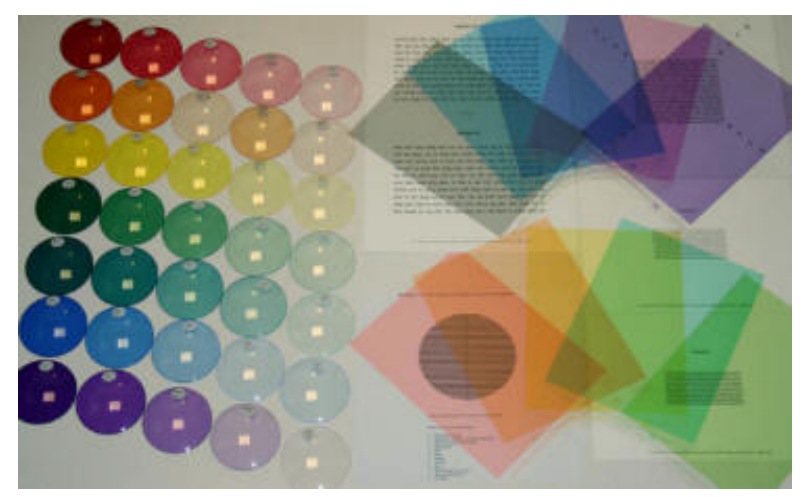

Figura 29: Overlays e lentes coloridos

Fonte: Adaptado de [11] 


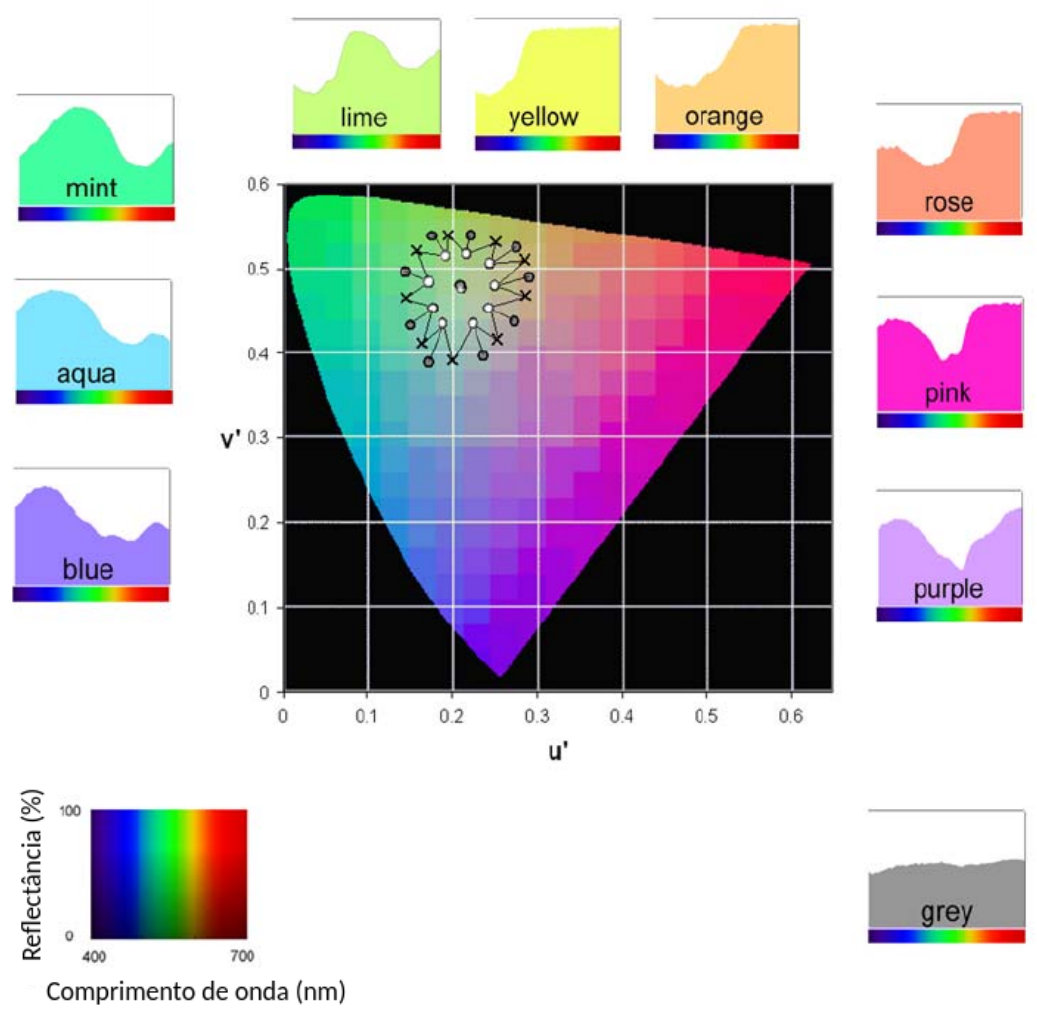

Figura 30: Cromaticidades das 9 cores das overlays (círculos brancos) e a overlay cinza (ponto central) quando são sobrepostas numa página branca. As cromaticidades das overlays duplas da mesma cor são os círculos cinza externos, e as cruzes representam as overlays duplas com a cor vizinha

Fonte: Adaptado de Wilkins (2003) [216]

\subsubsection{Lentes}

As distorções não ocorrem unicamente quando o indivíduo esta lendo um texto impresso. Ao escrever ou ao ler avisos nas ruas a pessoa esta exposta a excesso de brilho, contrastes e/ou padrões de linhas que favorecem o aparecimento dos sintomas da síndrome. Assim, lentes coloridas podem ser utilizadas para filtrar diretamente a luz incidente no olho, melhorando a capacidade ler à distância, como, por exemplo, a louza da aula, e de escrever. As lentes são mais convenientes que as overlays em diversas situações da vida e também podem ser mais duráveis e confortáveis, embora seu custo seja relativamente elevado.

A cor da lente pode ser selecionada com maior precisão mediante um equipamento chamado Colorímetro Intuitivo [216]. O colorímetro intuitivo é um equipamento óptico que ilumina uma página do texto com luzes coloridas. A cor pode variar em tonalidade, saturação e brilho. A tonalidade e a saturação são contínuos, enquanto 4 níveis de brilho estão disponíveis. O funcionamento deste equipamento será melhor explicado na seção 
Diagnóstico.

\subsection{Diagnóstico}

Os sintomas da Síndrome de Irlen ou Estresse Visual separadamente não são específicos, exclusivos, nem adequados para diagnóstico. Por exemplo, dores de cabeça ou algumas distorções podem ter causas optométricas, o que deveria ser corrigido antes de continuar com um diagnóstico de EV ou SI. Portanto, antes de iniciar com os testes e observações para fazer o diagnóstico da Síndrome é necessário revisar se estão presentes outras condições optométricas, tais como erro refrativo, anormalidades do sistema binocular ou anormalidades acomodativas. De fato, num estudo feito por Evans [69] pacientes que tinham consultado por ter suspeita de EV foram confirmados com diagnósticos diferentes à síndrome. Assim, vários autores reforçam a necessidade de consultar profissionais na área do cuidado da saúde visual para descartar e corrigir outras condições que poderiam estar causando alguns dos sintomas compartilhados com o EV.

Por outro lado, num estudo feito por Monger et al. [145] determinou-se que exames visuais de rotina, tais como erro de refração, acuidade visual, acuidade estereofônica, amplitude de acomodação, ponto de convergência próximo, heteroforia associada à proximidade, visão de cores e motilidade ocular, não conseguiram identificar os participantes que se beneficiaram de filtros espectrais em termos de velocidade de leitura.

Assim, uma vez que o indivíduo consultou o profissional na saúde visual e foram descartados ou tratados problemas refrativos e/ou optométricos é possível continuar com o diagnóstico do EV. Justamente, uma das críticas que é feita à Síndrome de Irlen é que para ser diagnosticada é necessário que o indivíduo apresente melhoria com os filtros espectrais. Por isso, além de exibir alguns sintomas e sinais, e necessário que uma triagem com filtros espectrais seja feita.

Existem duas formas de prescrever os filtros espectrais para diagnosticar Síndrome de Irlen ou EV atualmente, utilizando o Método Irlen $[5,93]$ ou utilizando o Colorímetro Intuitivo [215]. 


\subsubsection{Método Irlen}

Este método também pode ser chamado de screening. A execução desde método começa pela aplicação de um questionário chamado IRPS (Irlen Reading Perceptual Scale) o qual dá uma pontuação ao auto-relato do indivíduo sobre dificuldades na leitura e desconforto ocular. Este inclui perguntas sobre o historial de leitura do indivíduo (sensações na leitura) e sobre perturbações físicas ou perceptuais, como fadiga ocular ou enxaquecas enquanto lêem. Certa pontuação na escala do questionário indica se é necessário realizar uma segunda parte que envolve testar as anormalidades visuais enquanto são realizadas tarefas perceptuais e é selecionado a overlay adequada.

Nesta segunda parte, algumas tarefas são desenvolvidas para detectar a dificuldades perceptuais associadas com os sintomas da SI, e mediante elas é possível selecionar a overlay apropriada. Durante cada tarefa é perguntado para os participantes o quê estão vendo, com perguntas tais como: as linhas estão estáticas, tremem, dançam ou se mexem?, o fundo sobe ou fica no lugar?, as letras ou palavras parecem pular do texto, ficam 3D?. A overlay preferida é selecionada mediante o processo de eliminação, baseado nos relatos dos participantes sobre as cores das overlays que fazem com que o texto fique mais claro, definido e nítido, inclusive estático. Uma vez escolhida a overlay é possível combiná-la junto com outras para ver se a percepção melhora ainda mais [93]. Os participantes são orientados a ler um texto em voz alta com e sem overlay. O avaliador então observa o desenvolvimento na leitura do participante e os comentários durante a realização novamente das tarefas. Quanto maior o número de anomalias perceptuais e maior o número respostas altamente pontuadas no IRPS sejam reportadas, maior a severidade nos sintomas da SI.

O procedimento descrito anteriormente visa principalmente a orientar a escolha da overlay mais adequada para o indivíduo. Alternativamente, um procedimento parecido pode ser realizado com lentes de prova para realizar a escolha da cor da lente para os óculos (ver figura 29).

\subsubsection{Colorímetro intuitivo}

O colorímetro intuitivo é um equipamento óptico que ilumina uma página do texto com luzes de diferentes comprimentos de onda (cores diferentes). A cor pode variar em tonalidade, saturação e brilho. A tonalidade e a saturação são contínuos, enquanto 4 níveis de brilho estão disponíveis. A figura 31 mostra o equipamento sendo utilizado. 


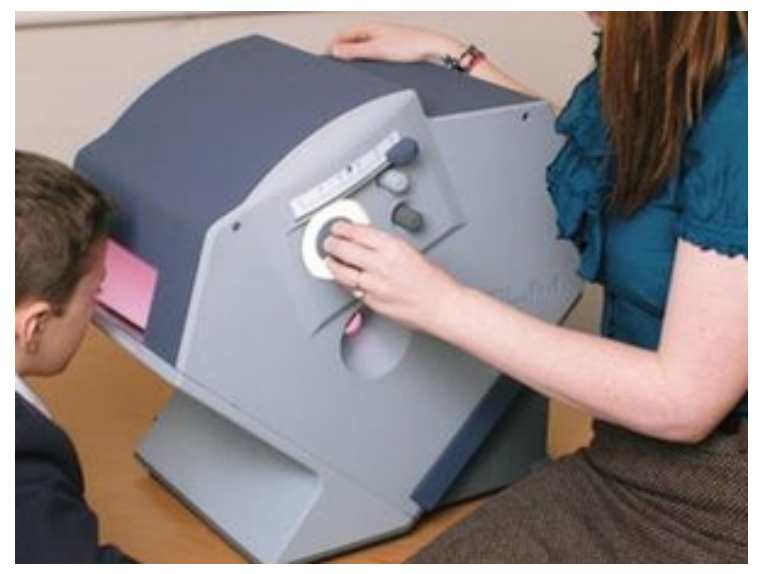

Figura 31: Colorímetro intuitivo

Fonte: Wilkins (2003) [216]

Para estimar a cor de lente adequada para o paciente, este deve colocar a cabeça perto da abertura, desta maneira, seu campo visual é colorido pela luz da câmara interior do equipamento. O usuário olha uma página de texto que esta montada no interior da câmara. O texto esta formado por letras agrupadas ordenadas aleatoriamente simulando palavras num parágrafo. O texto é inicialmente iluminado com luz branca, e a seguir pergunta-se para o paciente pelas distorções que esta experimentando. A mudança de cor vai acontecendo gradualmente, aumentando a saturação e mantendo a tonalidade constante. Depois de alguns segundos a saturação começa a ser reduzida até chegar de novo ao branco, e é perguntado ao paciente qual situação, com cor ou branca, ele prefere. Seguindo este procedimento são testadas as 12 cores estabelecidas no equipamento [216].

Algumas cores são citadas como benéficas, outras como neutras e outras como desconfortáveis [216]. Com as cores que foram indicadas como benéficas repete-se o teste mudando a saturação, e mediante um processo de eliminação o paciente escolhe a cor com a saturação mais benéfica. Tendo a cor e mantendo a saturação constante, a tonalidade é alterada em pequenas quantidades. O paciente vê duas tonalidades muito parecidas em sequência e escolhe qual é melhor para ele. Tendo escolhido a melhor tonalidade, o paciente deve ajustar novamente a saturação com o objetivo de escolher a saturação mínima para claridade e conforto. A seguir, o paciente deve julgar a sua preferência entre 3 níveis de brilho. Uma vez definidas a cor, saturação, tonalidade e brilho, um software indica qual lente de teste é correspondente à elegida pelo paciente (ver figura 29). O paciente experimenta as lentes teste sob várias fontes de luz e níveis de iluminação. Quando uma combinação de lentes teste é selecionada os óculos permanentes são fabricados.

Durante o exame com o colorímetro os sujeitos não têm uma referência de cor para 
comparar a cor na superfície do colorímetro. A visão do sujeito rapidamente adapta-se à cor, inconsciente de qual cor exatamente esta vendo (constância de cor). Este fato, permite realizar testes com o efeito placebo-controlado [219].

Tanto com o método Irlen como com o Colorímetro Intuitivo indica-se que a cor dos filtros é notavelmente específico e diferente para cada indivíduo. No entanto, várias pesquisas utilizam só uma cor de filtro para realizar os testes, nos quais têm-se obtido resultados que apoiam o uso de filtros espectrais para melhorar os indicadores de leitura $[160,164]$.

\subsubsection{Teste de sensibilidade ao contraste}

Uma disfunção no sistema Magnocelular tem sido proposta como a causa mais plausível que estaria gerando os sintomas visuais na dislexia [197] e no EV. A sensibilidade ao contraste é uma das tarefas nas quais o sistema magnocelular encontra-se envolvido [147]; portanto, testes de sensibilidade ao contraste também são utilizados para complementar um possível diagnóstico de Síndrome de Irlen.

Este teste avalia a qualidade da visão em diferentes níveis de iluminação e/ou de contraste, por meio de projeções de imagens que podem ser padrões listrados com diferentes frequências espaciais, em diferentes direções e aparecendo em diversas localizações do campo visual. Para que o resultado do teste de sensibilidade ao contraste seja válido, num possível diagnóstico de EV, é importante que outras doenças tenham sido descartadas previamente, pois este tipo de teste também é utilizado para complementar diagnósticos de catarata, degeneração macular, retinopatia diabética, entre outras.

\subsubsection{Teste de sensibilidade a Padrões Listrados ou Pattern Glare (PG)}

Relatos de ilusões geradas a partir de padrões listrados ou grades foram formalizados como o resultado do Teste Pattern Glare. As distorções perceptuais relatadas em resposta a parâmetros espaciais específicos parecem estar associadas a dores de cabeça fortes e fadiga ocular.

O método de teste é simples; consiste em orientar o paciente para fixar o olhar num ponto preto no centro da grade por 5 segundos e pedir para responder uma série de 
7 perguntas sobre alguma distorção que possa ser percebida (por exemplo brilhos ou desvanecimento). O número de respostas afirmativas marca uma certa pontuação no teste. A ordem do teste vai da grade 1 à 3 [67]. Nas figuras 32, 33 e 34 podem ser vistas grades que são usadas no Teste de Pattern Glare, as frequências espaciais das imagens não estão configuradas exatamente como as do teste original, mas servem para ilustrar a diferença relativa entre os três tipos de grades.

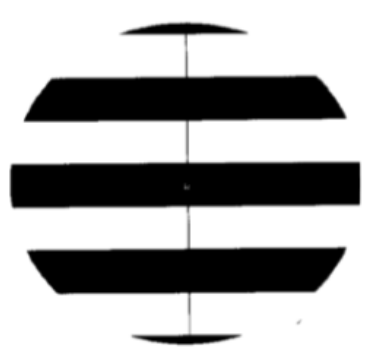

Figura 32: Grade número 1 do teste Pattern Glare. $0.3 \mathrm{cpd}$ Fonte: Evans (2008) [67]

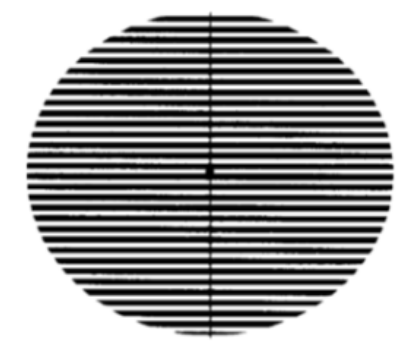

Figura 33: Grade número 2 do teste Pattern Glare. $2.3 \mathrm{cpd}$ Fonte: Evans (2008) [67]

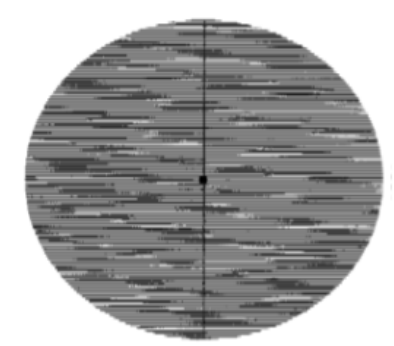

Figura 34: Grade número 3 do teste Pattern Glare. 9.4 cpd Fonte: Evans (2008) [67]

A associação entre dores de cabeça e distorções perceptuais acontecem predominantemente quando o Padrão espacial 2 (figura 33) é apresentado. Esta grade possui uma frequência espacial próxima àquela em que a sensibilidade ao contraste é maior, ou seja, 
2-5 ciclos por grau de ângulo visual (cpd, cycles per degrees), em que cada faixa subtende cerca de 10 minutos de arco. Indivíduos que se queixam de muitos sintomas de desconforto visual na vida cotidiana geralmente relatam mais distorções em resposta a grades com uma frequência espacial média $(2-5 \mathrm{cpg})$ em comparação com as grades que possuem frequências espaciais mais altas e mais baixas [67]. Indivíduos com desconforto visual relativamente baixo, por outro lado, geralmente relatam mais distorções em resposta a uma grade de alta frequência espacial (por exemplo, 9-12 cpd) do que uma grade de frequência espacial média [51], embora possam relatar menos distorções no geral. A natureza das distorções na grade de alta frequência espacial pode diferir daquelas na grade de frequência espacial média, refletindo uma maior contribuição relativa de fatores óticos em oposição a fatores neurológicos [67].

Foi descrito que as pessoas que dizem enxergar vários tipos de distorções tendem a relatar maior quantidade de dores de cabeça fortes, a experimentar mais distorções nos dias em que irão ter uma dor de cabeça forte e encontram a grade número 2 (ver figura 33) mais aversiva [67]. Pacientes que apresentaram níveis altos de Pattern Glare relataram se beneficiar com o uso de filtros espectrais [66, 86, 145].

\subsubsection{Sinais para diagnóstico}

Como mencionado anteriormente, num estudo feito com o método Delphi [72], o qual revisa os critérios diagnósticos para o EV na literatura e relata uma análise Delphi dos critérios atualmente utilizados na prática clínica, sugere-se que se na busca de um diagnóstico de EV dois dos três sinais seguintes estão presentes, então estes seriam indicadores da presença desta condição. Estes sinais seriam:

1. Uso voluntário dos filtros espectrais por mais de três meses. O que indicaria que o benefício é suficientemente bom como para fazer diferença na vida diária e continuar usando os filtros.

2. O uso dos filtros espectrais melhora o desempenho na leitura em mais de $15 \%$ (com o uso do WRRT)

3. Resultado 3 no teste de Pattern Glare com uma grade de frequência espacial média. Indicaria uma alta sensibilidade a padrões listrados com frequência espacial inofensiva para a população sem EV. 
O diagnóstico que determina se o indivíduo possui ou não a Síndrome de Irlen esta baseado na melhoria no desempenho perceptual e na leitura. Este critério, de resposta ao tratamento em vez de uma sintomatologia positiva a partir de dados de um teste, tem sido apontado como potencialmente fraco e que poderia dar resultados inválidos [183]. No entanto, se o objetivo é aliviar os sintomas do indivíduo, e os filtros espectrais os diminuem ou eliminam, poderia se considerar que o tratamento é eficaz.

\subsection{Discussão sobre a definição do Estresse Visual ou Síndrome de Irlen e seu tratamento com filtros espectrais}

O mesmo conjunto de sintomas têm recebido diferentes nomes, entre eles, Estresse Visual (comumente utilizado no Reino Unido) e Síndrome de Irlen (utilizado nos Estados Unidos). Na bibliografia encontrada sobre o tema são identificados diferentes conceitos para definir o Estresse Visual ou SI, tais como: (a) uma condição na qual sintomas de desconforto visual vivenciados durante a leitura são relatados como aliviados pelo uso de overlays e filtros coloridos; (b) um agrupamento de sintomas somáticos e perceptivos desencadeados por flicker de luz e/ou padrões listrados de alto contraste; (c) casos em que pessoas com dificuldades na leitura melhoram seu desempenho com o uso de overlays, e pioram novamente quando estão sem elas; e (d) uma condição caracterizada pela hiperexcitabilidade cortical e, como tal, relacionada à epilepsia fotossensível e à enxaqueca [183].

Pela similaridade que possuem alguns sintomas individualmente quando comparados com sintomas de outras condições optométricas ou neurológicas como diplopia, fotofobia e fadiga ocular, seu delineamento como síndrome ainda gera debate. Consequentemente, com base no conhecimento atual, e reconhecendo que nem todos os pacientes experimentam exatamente o mesmo conjunto de sintomas (nem no mesmo grau) ou mostram respostas idênticas ao tratamento é apropriado tratar este conjunto de definições como relacionadas à mesma condição.

Um dos principais sinais para elaborar um diagnóstico de EV é a melhoria dos sintomas a partir do uso dos filtros espectrais. No entanto, ainda existe a controvérsia sobre a validade dos filtros espectrais como tratamento. Algumas revisões sistemáticas afirmam que a evidência de qualquer efeito benéfico dos filtros na leitura é pouco convincente e os resultados podem ser tendenciosos [80,143]; no entanto, outros trabalhos, que embora reconhecem que existe limitações na metodologia de algumas pesquisas, concluem que 
os filtros espectrais podem ser utilizados com segurança [70]. De forma geral, todos os trabalhos em que se discute sobre a validade do tratamento com overlays e lentes coloridas, concluem que são necessários testes controlados, randomizados, com metodologias, análises e medidas nas que as duas partes da argumentação concordem. 


\section{HIPÓTESES SOBRE AS CAUSAS DO ESTRESSE VISUAL E OS EFEITOS DOS FILTROS ESPECTRAIS}

Nesta secção serão discutidas as principais hipóteses sobre os mecanismos do sistema visual que poderiam estar gerando os sintomas do EV e quais os efeitos dos filtros espectrais na correção do funcionamento de tais mecanismos.

Pesquisas onde o efeito placebo foi controlado mostraram que o efeito benéfico dos filtros espectrais não pode ser atribuído unicamente a efeitos placebo [34,160, 219, 224]. Esses estudos foram possíveis, uma vez que os efeitos dos filtros espectrais puderam ser avaliados sem que os sujeitos soubessem a cromaticidade exata da cor que fornecia o ótimo resultado para eles. Assim, possíveis causas da melhoria dos sintomas ocasionada pelos filtros devem ser consideradas.

\subsection{Hiperexcitabilidade cortical}

As linhas de texto podem ser vistas como padrões listrados com uma frequência espacial superior à normalmente vista nas cenas naturais, portanto, possuem uma estrutura espacial antinatural com um excesso de energia de contraste nas frequência espaciais médias [217]. Estudos mostraram que dependendo da frequência espacial das letras, o espaçamento entre as linhas e do contraste do texto, este pode gerar elevado desconforto em pessoas suscetíveis a este tipo de padrões [223,229]. Dependendo da susceptibilidade de cada pessoa, esta pode experimentar dores de cabeça ou enxaqueca, fadiga ocular, e ilusões de cor, forma e movimento. Este conjunto de sintomas de EV também é conhecido como Pattern Glare, pois são provocados pela observação de tais padrões.

Evans et al. [67] num estudo realizado com crianças que tinham dificuldades na leitura 
ou apresentavam astenopia ${ }^{1}$ e/ou distorções visuais, e um grupo controle sem sintomas, menciona que os sujeitos com EV mostraram-se bastante suscetíveis às grades experimentais para testar Pattern Glare (ver seção 3.3.4). Neste estudo, indica-se que o Pattern Glare esta associado com a sensibilidade à luz e com as visões de letras pulando da folha de texto.

As ilusões visuais que são experimentadas no Pattern Glare, pensa-se, são produto de uma hiperexcitação do córtex cerebral $[67,216]$. Crianças que beneficiam-se com os filtros têm mais probabilidade de ter a enxaqueca como sintoma familiar que aquelas que não se beneficiam; e em indivíduos com enxaqueca considera-se que o córtex é hiperexcitável $[216,217,224]$. Tal hiperexcitabilidade explicaria a sensibilidade à luz ou fotofobia. As distorções visuais seriam produto de um disparo anormal dos neurônios; isto ocorre por exemplo, quando se olha para algumas imagens que causam ilusões visuais, onde os neurônios que recebem sinais de movimento são equivocadamente excitados. Dependendo da configuração do texto (frequência espacial e contraste), este pode possuir características estressantes e gerar alguma ilusão visual. A figura 35 é uma típica imagem utilizada para gerar ilusões de movimento.

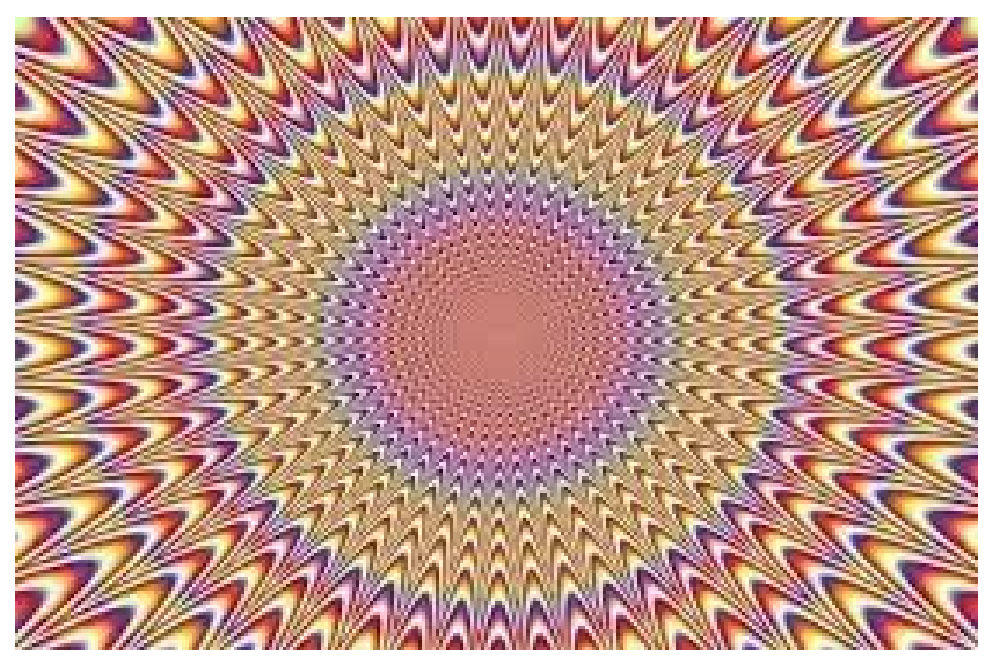

Figura 35: Imagem que gera uma ilusão visual de movimento

Fonte: Adaptado de [7]

A atividade celular no córtex muda a medida que as imagens mudam. Deste modo, caso alguma característica da imagem, como a cor, mude então a atividade cerebral deveria mudar também. Isto, porque a sensibilidade das células nervosas é diferente dependendo

\footnotetext{
${ }^{1} \mathrm{~A}$ astenopia ou esforço ocular é uma condição oftalmológica que manifesta-se através de sintomas como fadiga, dor em/ou ao redor dos olhos, visão embaçada, dor de cabeça e, ocasionalmente, visão dupla. Os sintomas costumam ocorrer depois da leitura, trabalho em computador ou outras atividades que envolvem a realização de tarefas visuais tediosas.
} 
do comprimento de onda, assim como da energia que é transmitida pelos fotorreceptores [216]. Desta forma seria possível que a filtragem de alguns comprimentos de onda diminuam ou redistribuam a quantidade de energia de excitação nas células nervosas, reduzindo a excitação em regiões hiperexcitáveis do córtex. Caso seja isto o que acontece, seria explicado o por quê as distorções e as dores de cabeça são reduzidas em indivíduos com SI ao utilizar filtros espectrais. No entanto, a especificidade da cor para cada indivíduo pode ter uma explicação mais complexa [216].

Os filtros espectrais têm se mostrado benéficos numa faixa de desordens que envolvem o sistema visual e estão associados com hiperexcitabilidade do córtex cerebral. Dentro destas desordens estão incluídas a epilepsia, enxaqueca, esclerose múltipla e a neve visual $[41,87,118,131,206,221,224,226,233]$.

Estudos feitos utilizando ressonância magnética funcional (fMRi) reportaram diminuição nos sintomas de desconforto visual em pacientes com enxaqueca e dores de cabeça (sintoma que está presente nos casos mais severos de EV) [87] depois de utilizar os filtros espectrais. Adicionalmente, em um estudo feito por Chouinard et al. mostra-se que sujeitos com SI apresentam alguma intensidade de excitação maior em algumas zonas cerebrais quando comparados com o grupo controle [48], apoiando assim a teoria do córtex hiperexcitável. Observe-se, no entanto, que neste estudo alguns dos participantes tinham fadiga crônica como comorbidade.

Foi sugerido que o Pattern Glare (sensibilidade a padrões listrados) é mais provavelmente parte do mecanismo do EV do que especificamente a sua causa. Os estudos com fMRi até agora feitos, embora promissores, possuem uma amostra pequena de participantes e/ou possuem comorbidades. Supondo que efetivamente o córtex dos indivíduos com EV seja hiperexcitado quando estimulado com padrões listrados, tais como linhas de texto, a alta intensidade dos sinais nervosos no córtex poderiam ser devido a ruído nos sinais que chegam naquelas áreas do cérebro. Esses ruídos podem estar sendo originados num nível baixo de processamento, como nos mecanismos de codificação da informação visual na retina.

\subsubsection{Por que funcionam os filtros}

Wilkins et al. [220] sugeriram quais mecanismos neurais estariam por trás do tratamento com filtros espectrais. Argumentaram que na epilepsia fotossensível os pacientes são sensíveis a padrões listrados dentro de uma faixa limitada de orientação, indicando 
que, pelo menos nesses pacientes, a excitabilidade cortical pode ser local e confinada a um número limitado de colunas de orientação (os grupos de células no córtex que responde a linhas de uma determinada orientação); e que é possível que na enxaqueca e o EV a excitabilidade cortical seja similarmente local. Uma vez que a representação de cores no córtex segue mapas topográficos nos quais as células que respondem a uma determinada cor estão localizadas juntas e dispostas com vizinhos de cores semelhantes, seria razoável inferir que os filtros espectrais iriam alterar a distribuição do padrão de disparo dentro do córtex visual. Assim, um mecanismo possível para os benefícios dos filtros coloridos é, portanto, que eles redistribuem a atividade dentro do córtex visual de maneira a reduzir a quantidade de excitação em regiões localmente hiperexcitáveis.

Baseado num estudo onde foi adquirido o nível de oxigenação em sangue no córtex visual (BOLD - blood oxygenation level-dependent) como resposta aos padrões listrados prejudiciais em pacientes com enxaqueca, Wilkins [220] afirma que a teoria da hiperexcitabilidade cortical possui evidências que a sustentam. Relata que num paciente com enxaqueca as lentes com uma cor terapêutica reduziram o tamanho da resposta BOLD, enquanto as cores de controle não tiveram efeito. Assim, as lentes com uma cor prescrita estariam reduzindo seletivamente a resposta em frequências espaciais epileptogénicas na área V3 do córtex visual. Comenta que seria interessante estimar se este tipo de resultados se replicam em crianças com EV, pois como previsto pela teoria do EV, as crianças que mais se beneficiam dos filtros coloridos geralmente têm enxaquecas, ou sofrem de enxaqueca na família. Wilkins afirma então que a teoria da hiperexcitabilidade cortical estende-se a uma variedade de distúrbios do sistema nervoso central, nos quais os sintomas de EV estão presentes e os filtros espectrais foram considerados benéficos [218,221]

\subsection{Anormalidades do sistema óculo-motor}

Existe a hipótese de que o mal funcionamento do sistema óculo-motor poderia causar as distorções vistas no EV. Como mencionado na seção 2 os movimentos oculares de sujeitos com deficiência na leitura tais como sacadas, regressões, tempo das fixações e span de reconhecimento são irregulares.

Vários autores documentaram como anormais este tipo de funções em pessoas com dislexia ou dificuldades na leitura $[15,19,33,135,161]$. No estudo feito por Dahhan et al. estudantes universitários com dificuldades na leitura apresentaram maior número de sacadas e sacadas mais curtas, e maior tempo de fixação que o grupo controle de 
leitores normais [15]. Alencar et al. estimaram alguns parâmetros de movimento ocular relacionados à leitura em sujeitos com EV, antes e depois do uso de overlays. Seus resultados mostraram que o uso de filtros espectrais diminui significativamente o número de fixações e regressões realizadas, além de aumentar a faixa de reconhecimento do texto [19].

Poynter et al. [158] sugeriu que embora seja possível que anormalidades do sistema oculomotor possam resultar em habilidades de leitura fracas, é igualmente possível que a falta de interesse e/ou prática na leitura (que poderia estar vindo de um desconforto significativo na hora de realizar esta tarefa) signifique que a pessoa não estaria exposta o suficiente ao treinamento das funções oculomotoras, e por isso não consegue ter uma boa execução das mesmas. De fato, existem adultos com EV que, a pesar de apresentarem sintomas, têm adotado estratégias ou resistência para conseguir ler e é possível que seus movimentos oculares estejam dentro de parâmetros considerados como normais; embora os apresentem quando chegam em certo nível de EV.

Medland reforça a teoria de falta de treinamento de Poynter e postula que quando não se adquire um treinamento nos movimentos oculares na leitura é possível executar com baixo rendimento tarefas que requerem destas habilidades. Assim, o fato de que pessoas com dificuldades na leitura tenham um desempenho baixo em tarefas relacionadas à leitura, não implica que as dificuldades na leitura sejam causadas pelos movimentos oculares fracos, pois foi mostrado que disléxicos possuem movimentos oculares similares a pessoas sem dificuldades na leitura quando realizaram tarefas visuais diferentes da leitura [139]. O estudo de Vagge et al. suporta a hipótese de que uma alteração nos movimentos oculares não depende de uma disfunção do sistema óculo-motor, mas que é uma falha secundária de um defeito no processamento visual do material linguístico [212].

Stein [198] afirma que os movimentos oculares irregulares são causados por deficiências no controle dos mesmos; e já que o sistema magnocelular desempenha um papel dominante na orientação visual dos movimentos oculares, seu mal funcionamento claramente comprometeria o controle rápido e preciso dos olhos ajudando a causar dificuldades na leitura.

Além dos movimentos oculares na leitura serem erráticos, o movimento ocular de acomodação mostrou-se afetado nas pessoas com EV ou dificuldades na leitura $[23,62,170$, 181], sugerindo que alguns sintomas da SI poderiam estar surgindo a partir de flutuações acomodativas. 
Medidas de acomodação foram feitas em pessoas com SI [181] onde se mostra que as flutuações na acomodação para chegar no foco ótimo (melhor imagem) são anormalmente longas nestes sujeitos. Tais flutuações são reduzidas com o uso de lentes espectrais, mas este efeito parece ser independente da especificidade da cor da lente, tanto pode-se dar com as lentes prescritas como com sua cor complementária ou com lentes escuras. Assim, este benefício poderia estar relacionado com a redução da luminosidade (melhora no contraste da luminosidade), ou seja, seria dependente da luminância e não da cromaticidade. Atrasos na resposta de acomodação em indivíduos com EV também foram reportados por Allen et al., nesta pesquisa o uso de overlays diminuiu tal atraso. Mostrou também que o atraso acomodativo é maior em indivíduos que relatam desconforto visual e Pattern Glare [23].

O mecanismo de acomodação do olho é o que permite ajustar o foco continuamente para obter o melhor compromisso possível entre os comprimentos de onda. O olho toma certo tempo para fazer os ajustes necessários no foco, sendo que o foco não fica perfeito. A acomodação esta influenciada pelos comprimentos de onda da luz visível. Comprimentos de onda curtos (aproximadamente entre 380-495nm - azuis) são refratados pela córnea e a lente mais que os comprimentos de onda longos (maiores que 495nm - vermelhos). Como resultado disto, comprimentos de onda curtos e longos não podem ser focados ao mesmo tempo, um dos dois estará desfocado enquanto o outro estará nítido. Quando o olho foca na metade do espectro visível (cores amarelas e verdes) na retina, a luz com comprimento de onda curto (cores azuis) fica embaçada porque o seu foco encontra-se na frente da retina, enquanto a luz com comprimento de onda longo tem seu foco por trás da retina, o que faz que também pareça desfocada. Este efeito acontece normalmente na retina de todos os humanos em pequeno grau, sendo que alguns pigmentos da mácula ajudam a diminuir este evento [32]. O efeito descrito anteriormente é chamado aberração cromática e pode acontecer tanto longitudinal como lateralmente (ver figura 36). Na figura 37 pode ser visto como se visualizaria uma imagem de pontos brancos num fundo preto com Aberração cromática longitudinal e lateral. Note-se que a imagem de aberração cromática lateral gera um efeito parecido como o mencionado na visão de Swirl relatada na Síndrome de Irlen (ver figura 26).

A aberração cromática longitudinal (LCA pela siglas em inglês) fornece um importante estímulo ao reflexo do sistema de acomodação $[113,193]$ através da relação entre contrastes dos cones-L/M (cone-L: cone que recebe comprimentos de onda longos. coneM: cones que recebem os comprimentos de onda médios). Esta relação fornece o sinal de direção que requer a acomodação. Caso exista um atraso na acomodação, os com- 


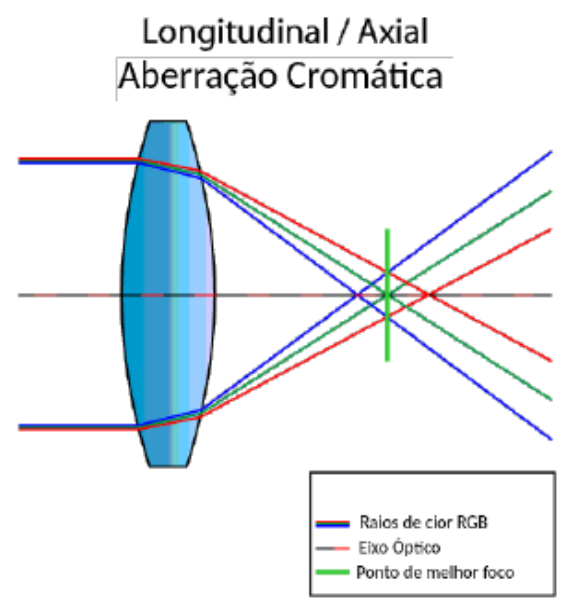

(a)

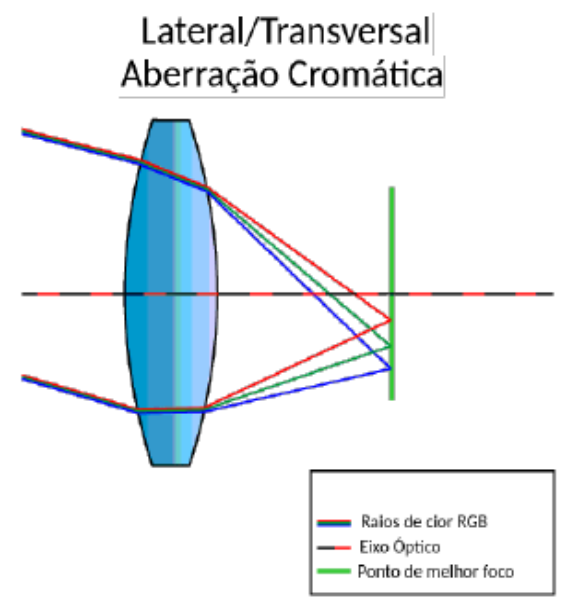

(b)

Figura 36: Aberração cromática longitudinal (a) e lateral (b)

Fonte: Adaptado de [1]

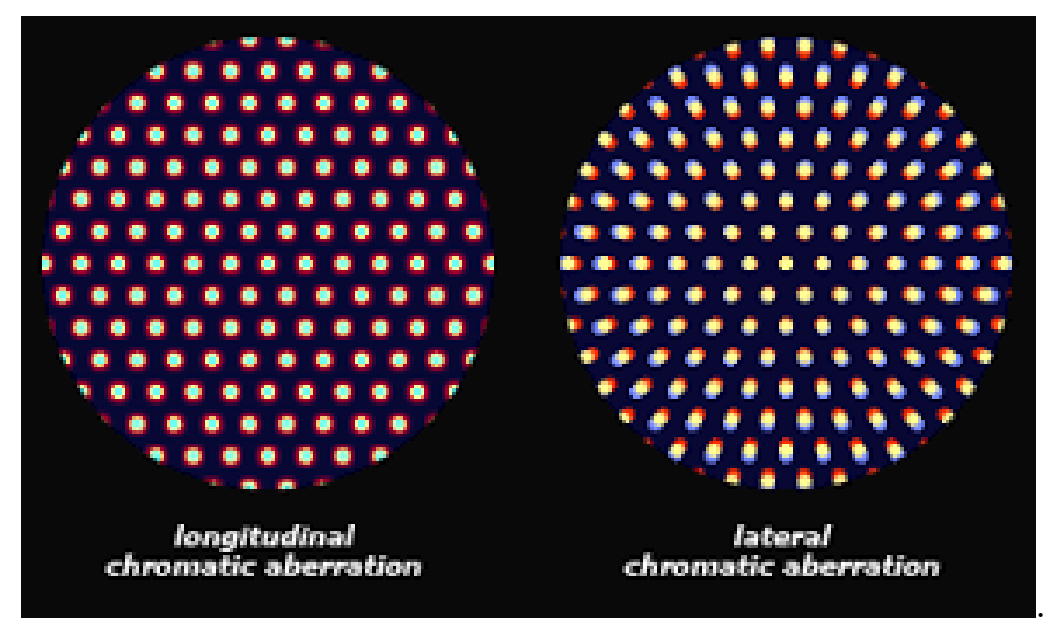

Figura 37: Pontos brancos no fundo preto vistos com Aberração cromática lateral e longitudinal Fonte: Adaptado de Kaplonek (2018) [103]

primentos de onda longos estarão mais desfocados que os comprimentos de onda médios. Um contraste do cone-L menor que o contraste do cone-M indica um incremento na acomodação. Similarmente, se o contraste do cone-L é maior que o do cone-M precisa-se um decremento na acomodação [62]. Um alvo vermelho requer um pouco mais de acomodação que um alvo branco. Neste sentido, a LCA afeta a resposta do mecanismo acomodativo de maximização de contraste ou minimização de embaçamento.

A sensibilidade na relação de contraste dos cones-L/M tem sido correlacionada com a leitura. Num estudo feito por Chase et al. sujeitos realizaram um tarefa que consistia 
em decidir qual grade estava movendo-se mais rápido; o estímulo foi isolado para cada tipo de cone com variação em contraste e velocidade [46]. Nesta pesquisa, aqueles que apresentavam uma diferença entre as velocidades de resposta dos cones-L/M superior, tendiam a ter dificuldades na leitura. Estes resultados sugerem que é possível que respostas acomodativas fracas causadas por uma demanda de acomodação incrementada, estejam ocasionando as dificuldades na leitura [62].

Drew et al. encontraram que existe uma correlação entre os problemas na acomodação e/ou fadiga visual e a cor dos filtros espectrais escolhidos para aliviar esses sintomas; três padrões foram encontrados. Primeiro, estudantes que apresentavam alta fadiga ocular em termos de frequência do sintoma, escolheram cores que reduziam a demanda acomodativa, ou seja, cores que tendem a azul saturado. Segundo, aqueles com sistemas de acomodação/vergência fracos reduziram esta demanda mediante a seleção de cores com tendência ao verde saturado. Terceiro, aqueles com acomodação/vergência normal e sem fadiga visual frequente escolheram cores que não têm efeito na demanda de acomodação ou que a aumentam, como são as cores amarelas fortes, laranja e vermelho. Isto sugere que a função acomodativa sistematicamente influenciaria as preferências de cor dos indivíduos [62]. Scott et al. [180] mostraram, similarmente, que indivíduos com alto nível de EV e pouca acomodação escolheram as overlays azuis ou de comprimento de onda curto, e por outro lado, aqueles que escolheram as overlays com comprimento de onda longo (laranjas, rose) apresentavam uma amplitude de acomodação grande.

Do anterior pode-se inferir que um desbalance na relação dos pesos no contraste dos cones-L/M pode influenciar o sinal da direção de acomodação indicando ao sistema acomodativo para realizar um esforço diferente ao que verdadeiramente é necessário. Deste modo, a entrega de informações imprecisas ao sistema acomodativo podem levar à ocorrência de alguns sintomas da SI como fadiga ocular e suas consequências (como visão embaçada) e visões com Aberração cromática lateral ou longitudinal.

Alguns autores indicam que disfunções binoculares e acomodativas que estão presentes na SI podem estar correlacionadas com esta, em lugar de ser propriamente sua causa $[68,216]$. Wilkins sugere que os benefícios das lentes espectrais não são devidos à ótica do olho e em particular da acomodação. O atraso na acomodação tem se mostrado maior em indivíduos com EV, mas a cor não parece influenciar o atraso em virtude da aberração cromática, em vez disso, os mecanismos fisiopatológicos parecem ser corticais [2].

Num estudo feito em pessoas diagnosticadas com PRVS (Pattern Relative Visual 
Stress) e grupo controle foram manipuladas as respostas acomodativas mediante o uso de lentes positivas e negativas para estudar a associação entre sintomas de Pattern Glare e a acomodação [22]. O estudo mostrou que as pessoas com PRVS possuíam grande atraso na acomodação o qual era reduzido com o uso de overlays. O grupo controle foi induzido a ter um atraso na acomodação mediante o uso de lentes de prova; neste grupo não aconteceram mudanças no atraso na acomodação com o uso das overlays [22]. Nesta pesquisa, o teste de Pattern Glare foi realizado nos dois grupos com e sem overlays e com as as lentes de prova; os resultados do teste de PG mantiveram-se constantes, o que sugere que os sintomas do PG não estão fortemente associados à acomodação. Isto, de acordo com trabalhos anteriores em que não houve diferença no atraso acomodativo entre um alvo estressante e não estressante, possivelmente aconteceu porque as características de demanda devido à presença de uma lente de prova estavam mascarando quaisquer efeito [23]. Se os filtros espectrais tivessem diminuído a demanda acomodativa do grupo controle, seria possível afirmar que a hipótese de Chase et al. [46] era verdadeira quando propôs que a seleção de cores que reduzem a demanda acomodativa induzida pela Aberração cromática podia ser uma maneira de melhorar o foco e reduzir os sintomas. No entanto, os resultados com o grupo controle e lentes de prova mostraram que não é assim. Contudo, o autor indica que seria possível que a escolha de filtros espectrais pelo grupo de controle possa diferir (e ser mais apropriado) quando tal atraso esteja presente, ou seja, com as lentes de prova sendo utilizadas na hora da escolha do filtro espectral. Assim, é possível que a melhoria na acomodação das pessoas com EV venha de uma regulação sistêmica que influencia também os mecanismos de acomodação.

Se a disfunção na acomodação está relacionada com o desbalance na relação dos pesos no contraste dos cones-L/M, Skottum [185] menciona que a relação entre os cones seria dependente das entradas relativas dos cones-L e M no sistema Magnocelular.

Allen et al. [22] propuseram que a hipótese da hiperexcitabilidade cortical poderia fornecer uma explicação à redução no atraso de acomodação com o uso dos filtros espectrais. Sugerem que se o texto é desconfortável para os leitores que são suscetíveis ao Pattern Glare por causa da super-ativação cortical, o embaçamento da imagem poderia se reduzir devido à redução na aversividade do estímulo visual como consequência da redução de contraste; embora tal redução fosse pequena. Se a cor reduz essa ativação excessiva, então reduziria o atraso na acomodação. 


\subsection{Deficiências do caminho Magnocelular}

Lane, K. A. no seu livro Developing ocular motor and visual perceptual skills: An activity workbook [117], indica uma série de sintomas que poderiam se manifestar na leitura, se o indivíduo apresentasse deficiências no sistema Magnocelular. Estes são:

- Os leitores são podem ver parte das palavras, não possuem uma visão periférica clara

- Eles não distinguem de qual fixação vem a informação (anterior ou atual). Não estão muito cientes do arranjo espacial das letras o que pode resultar em erros de leitura e/ou reversões de letras e palavras

- Pode resultar difícil para eles aprender algum grafema, uma vez que a forma das letras pode parecer instável

- A pessoa pode fazer erros diferentes na leitura da mesma palavra

- O leitor pode reclamar de ver letras do texto movimentando-se

- Podem pular linhas durante a leitura

- Podem fazer uso dos dedos para se ajudarem a manter a linha de leitura

Como mencionado em seções anteriores, a informação visual é transmitida ao cérebro através de dois caminhos paralelos, o Magnocelular (MC) e o Parvocelular (PC). Estes têm papéis específicos na leitura, sendo que o MC é o encarregado de guiar e controlar os movimentos oculares, e portanto, de dirigir o olhar para determinado ponto no texto, e o PC fornece ao cérebro informação detalhada do ponto de fixação, e no caso da leitura, extrai informação sobre as letras e palavras [230]. Quando os olhos vão de uma fixação a outra mediante movimentos sacádicos, a informação cognitiva continua no cérebro, no entanto, a informação visual é finalizada depois de cada fixação mediante a supressão sacádica. Caso a informação visual não seja apagada ao finalizar a fixação pode acontecer a Persistência visual, na qual as imagens da fixação atual e da anterior são vistas sobrepostas $[117]$.

Uma característica importante do caminho Magnocelular é o grande tamanho dos neurônios e seu revestimento grosso e isolado de mielina (substância feita de ácidos graxos) que lhe permitem levar os impulsos elétricos ao córtex cerebral mais rápido do que outros 
nervos. Esta velocidade é provavelmente um aspecto relevante no processamento visual na leitura, pois o MC deve realizar ações que guiam os próximos passos do PC, e portanto, deve transmitir certas informações antes que ele. Livingstone [126] num estudo com indivíduos disléxicos, encontrou que o caminho magnocelular em este grupo de indivíduos demora aproximadamente duas vezes mais em levar informação da retina ao córtex. Se o movimento de um ponto de fixação a outro enquanto se está lendo demora de 20 a 40 mseg, mas o impulso no MC que estimula a supressão sacádica demora $50 \mathrm{mseg}$ em ser ativado, estaria sendo gerado um atraso neste sinal, criando uma potencial sobreposição de imagens de palavras entre fixações consecutivas, como foi sugerido anteriormente na teoria da persistência visual $[172,188]$.

Uma pesquisa feita por Chahine et al. 2009 sugere que o mecanismo de supressão sacádica envolve processamento visual de mais alto nível no córtex, talvez da área MT [44]. Este estudo mostrou que a supressão da informação num olho está modulada pela luminância no outro olho, e já que o LGN decodifica informação de um olho só, as mudanças na supressão sacádica não poderiam estar vindo simplesmente do LGN; este tipo de interação precisaria do envolvimento dos neurônios binoculares do córtex visual para acontecer.

Assumindo que a supressão sacádica tem origem na área V5/MT do córtex é interessante mencionar que esta área é composta quase em $90 \%$ por fibras que levam a informação do sistema magnocelular, e portanto, o atraso na transmissão da informação do magnocelular poderia gerar as consequências previamente mencionadas. Cabe citar também, que se tem evidência de que o sistema koniocelular conjuntamente influencia as respostas da área MT [43].

A mielina (composta por ácidos graxos) é considerada importante para a rápida condução dos potenciais de ação. Desta maneira, alterações na mielinização dos nervos podem levar a uma deterioração da correta codificação e transmissão dos estímulos visuais rapidamente variáveis, sendo particularmente importante para o eficiente funcionamento dos neurônios na área V5/MT do córtex visual. A área V5/MT é espacializada na detecção do movimento e tem sido identificada como fraca ou comprometida negativamente em leitores deficientes [172].

Richardson et al. encontrou que o grau de severidade dos sinais clínicos que indicam uma deficiência de ácidos graxos esta correlacionada com a existência de problemas visuais na leitura [166]. Taylor também mostrou que pessoas com deficiência na leitura possuíam 
deficiências nos ácido graxos essenciais (HUFAs-Highly Unsaturated Fatty Acids) [204]. Richardson num estudo controle aleatório determinou que suplementando com extra HUFAs a dieta de crianças com problemas na leitura, pode-se melhorar a atenção, o comportamento e a leitura [167]. Outro estudo feito em adultos e crianças com SI estimou que este grupo possuía baixos níveis médios de ácidos graxos essenciais (n-3 e n-6) quando comparados com um grupo controle [191]. Assim, pela similaridade nos sintomas visuais das pessoas com EV e dislexia é possível conjecturar que a mielinização dos neurônios do MC poderiam estar comprometidas em ambas condições.

Stein [196] argumenta que as anormalidades no controle ocular de crianças com dislexia é devido a uma deficiência no sistema magnocelular; se o desenvolvimento deste sistema se vê prejudicado, claramente comprometerá o controle rápido e preciso dos olhos ajudando a causar problemas de leitura. Uma fixação estável nas letras ou palavras que estão sendo inspecionadas é importante para uma leitura bem-sucedida e essa estabilidade depende crucialmente do sistema magnocelular que detecta movimentos oculares indesejáveis que, de outra forma, poderiam fazer com que o texto pareça se mexer (por exemplo, microsacadas não controladas). Um sistema Magnocelular fraco, portanto, leva a uma fixação visual menos estável, o que leva, por sua vez, à possibilidade de palavras e letras parecerem se movimentar; um sintoma que muitas pessoas com EV e disléxicos reclamam. Associando que o EV e a dislexia compartilham sintomas na parte visual, e portanto, a hipótese de uma deficiência no sistema magnocelular, a conclusão de Stein indicaria que se a criança apresenta os sintomas próprios do EV na leitura, por conseguinte seu sistema magnocelular teria alguma deficiência [198].

\subsubsection{Filtros espectrais no sistema magnocelular}

A hipótese de que os filtros espectrais exercem uma influencia benéfica no desempenho do sistema magnocelular de indivíduos com dislexia originou-se, em parte, porque tais benefícios foram reportados inicialmente em disléxicos [216]. Contudo, agora se conhece que os filtros espectrais possuem efeitos benéficos tanto em sujeitos com dislexia quanto em aqueles que não a possuem. Embora seja complicado argumentar que os mecanismos que fazem com que disléxicos e não-disléxicos se beneficiem com o uso dos filtros espectrais são diferentes, devido à alta comorbidade e à sobreposição na sintomatologia que já foram demonstradas entre a dislexia e o EV, vários pesquisadores levantaram a hipótese de uma influência subjacente ou causal que pode explicar essa relação; a teoria magnocelular da dislexia propõe que uma deficiência no processamento visuo-temporal pode explicar a 
sintomatologia para ambos os transtornos [74].

Wilkins com a intenção de responder por que os filtros espectrais geram um efeito benéfico em pessoas com dificuldades na leitura, sugeriu que esses efeitos positivos não estariam necessariamente associados com deficiências no magnocelular [216]; e que portanto, seria improvável que as deficiências no MC fossem a origem da SI. Tal afirmação baseou-se num estudo no qual um grupo de indivíduos que usaram regularmente lentes espectrais e expressaram se beneficiar delas, realizaram tarefas que se sub-servem do sistema magnocelular (tais como percepção do movimento e sensibilidade ao contraste espaciotemporal). No estudo, o grupo de sujeitos com SI não apresentou diferenças significativas na capacidade de realizar tais tarefas quando comparados com o grupo controle; mas menciona-se que a não-correlação destes resultados com outros estudos pode ser devido a diferenças metodológicas [181]. Os autores do estudo mencionado expressam que deve ser reconhecido que a deficiência no sistema magnocelular em grupos específicos com dificuldades na leitura esta correlacionado com a severidade da deficiência e que alguns sujeitos com SI podem simplesmente não se ajustar na categoria testada; e se de fato uma deficiência no magnocelular é a base para uma insuficiência específica na leitura, ainda assim não forneceria uma completa explicação para os benefícios reportados ao uso de filtros espectrais e sua especificidade em cada indivíduo [181,216]. Evans mostrou, utilizando um grupo pequeno de crianças com SI (16 crianças), que elas possuem uma percepção ao flicker ${ }^{2}$ em $20 \mathrm{~Hz}$, similar à do grupo controle [68]; contudo, conclui que é prematuro dizer que crianças com SI não possuem uma deficiência no sistema visual transiente ou magnocelular.

Skottun [184] destaca a necessidade de diferenciar o sistema Magnocelular da via Dorsal e sua conexão com condições tais como a dislexia. Afirma que existem dados a favor e em contra de uma deficiência no "caminho magnocelular-dorsal" em conexão com a dislexia; e salienta que esta inconsistência é abolida quando se reconhece que o sistema magnocelular e a via dorsal são entidades separadas. No entanto, como resposta a Skottum, Stein [197] argumenta que 90\% da entrada visual do caminho dorsal é fornecida pelo sistema magnocelular, e que muitos dos neurônios dos quais a via Dorsal é composta expressam a mesma superfície-antígeno " assinatura" das células ganglionares magnocelulares da retina, indicando que são da mesma linhagem, isto é, fazem parte do mesmo sistema.

Vidyasagar [214] assumindo que efetivamente existe uma deficiência no magnocelular

\footnotetext{
${ }^{2}$ feixes de luz intermitentes. A percepção deste evento é atribuído ao correto funcionamento do MC
} 
em pessoas com dislexia e/ou dificuldades na leitura, propôs uma hipótese para o que pode estar acontecendo em tais sujeitos. Entretanto, esta explicação pode ser extrapolada para o EV, pois também explicaria por que os filtros espectrais ajudam a aliviar seus sintomas. Ele explica que poderia ser que a informação que chega na via Dorsal, a qual é quase exclusivamente proveniente do Magnocelular por meio das áreas V5/MT, esteja contaminada por sinais do sistema Koniocelular. As células do sistema koniocelular trazem consigo a informação dos cones-S (azuis) e devido às características destas fibras nervosas (por exemplo, velocidade de transmissão da informação), alguma interferência das células koniocelulares nas áreas alvo das células magnocelulares (mediante conexões laterais nas áreas do córtex V1 ou V5/MT) poderiam degradar o sinal espacial levado pelo sistema magnocelular à via visual Dorsal. Isto poderia afetar a função de spotlighting ou Foco de atenção do Magno na leitura. Assim, embora o sistema koniocelular inerve a via Dorsal, uma falha na seleção da área alvo poderia gerar atrasos nos sinais de feedback da via Dorsal.

Vidyasadar baseado nas pesquisas de Stein [194] e Ray [160] onde indivíduos com dislexia e/ou dificuldades na leitura beneficiaram-se de filtros espectrais amarelos ou azul, sugeriu que o fato da maioria dos indivíduos testados terem preferido o filtro amarelo encaixaria-se dentro da sua teoria; pois os filtros amarelos diminuem a interferência dos sinais dos cones-S, azuis. Contudo, diz que aqueles que preferem o filtro azul não só poderiam ter uma deficiência nas células do magnocelular senão também do koniocelular. Em tal caso, o uso de filtros azuis pode ser útil porque pode ajudar as células remanentes do koniocelular a serem melhor ativadas e a também diminuir a ativação do subsistema Parvocelular, criando um equilíbrio entre os sinais dos 3 subsistemas visuais.

Stein [194] expõe que os filtros amarelos estariam ajudando os sujeitos com uma função magnocelular fraca a diminuir o sinal dos S-cones que estariam inibindo o funcionamento do magnocelular [201]. Isto, faria melhorar a sensibilidade ao contraste e ao movimento; e isto por sua vez ajudaria a estabilizar os movimentos oculares na leitura [194]. Por outro lado, uma porcentagem das crianças testadas com problemas visuais na leitura, especialmente aquelas que queixam-se de Pattern Glare, não mostram se beneficiar com os filtros amarelos, mas apresentam melhorias com filtros de cor azul profundo (também chamado amarelo-negativo). Argumenta-se que é possível que os filtros ajudem porque diminuem a estimulação dos cones-L e M nestas crianças, permitindo um apropriado balanço entre os estímulos dos diferentes tipos de cones [194].

A hipótese de que uma deficiência no sistema magnocelular gera os principais sintomas 
visuais da dislexia e do EV é amplamente aceita. Pois o sistema magnocelular esta envolvido em diversas tarefas do processamento visual, incluindo direcionar o foco da atenção, a codificação da posição das letras e o reconhecimento das características globais do texto. Devido às suas múltiplas funções e lugares de projeção no cérebro, seria plausível que certos subsistemas do magnocelular funcionassem mais ou menos adequadamente, gerando os diferentes níveis de severidade dos sintomas. Esta hipótese ainda não se encontra inteiramente comprovada. No entanto, como menciona Stein [198], não existe uma experiência que prove ou refute de forma conclusiva a hipótese da deficiência do sistema magnocelular.

\subsection{Deficiência no sistema koniocelular}

Foi proposto que deficiências no sistema koniocelular poderiam estar envolvidas na sintomatologia da dislexia e do EV [94]. Como mencionado anteriormente, Vidyasagar [214] para explicar por que os filtros azul-amarelo mostravam-se beneficiosos para aliviar os sintomas do EV propôs que aqueles que preferem o filtro azul não só poderiam ter uma deficiência nas células do magnocelular senão também do koniocelular, e que em tal caso, o uso de filtros azuis pode ser útil porque poderia estar ajudando as células remanentes do koniocelular a serem melhor ativadas e a também diminuir a ativação do subsistema Parvocelular, criando um equilíbrio entre os sinais dos 3 subsistemas visuais.

Jayakumar [94] propõe que as vias que transportam sinais dos cones S (koniocelulares), podem ter sido integradas para auxiliar na atenção focal-espacial, e que isto poderia ter implicações nas patologias que envolvem o caminho Dorsal ou suas entradas aferentes, especialmente no que diz respeito ao papel da via Dorsal na atenção. A via Dorsal tem sido relacionada com o direcionamento da atenção visuo-espacial em tarefas tais como a leitura [124]. Li [122] mostrou que nas tarefas de busca visual, os sinais do koniocelular podem direcionar a atenção espacial quase tão bem quanto os sinais magnocelulares.

Os sinais dos cones-S podem chegar no córtex visual V1 via axônios koniocelulares ou pelas aferências que chegam na área V2 que posteriormente projetam na área MT. Jayakumar [94], apoiado na observação de que muitas células koniocelulares que entram na área MT são seletivamente direcionais [27], sugere que o sistema koniocelular desempenha um papel importante na percepção visual.

As células do sistema koniocelular participam na codificação da dimensão de cor 
amarelo-azul. A detecção do amarelo envolve os cones-L e M em alguma combinação. Assim, o sistema koniocelular pode ser influenciado por diferenças nas proporções dos cones-L e M. Isto parece particularmente relevante em relação ao processamento de movimento, pois há uma entrada koniocelular direta substancial do núcleo geniculado lateral para a área MT. Foi sugerido que esta entrada pode mediar a percepção do movimento na ausência de V1, o que presumivelmente significaria que ela poderia mediar a percepção do movimento na ausência de ambas as entradas, Parvocelular e magnocelular, na área MT [185]. Contudo, se alguns dos sintomas do EV associados à deficiência do magnocelular, tais como baixa percepção do movimento e da direção, estão relacionados a funções da área MT, já que as fibras do sistemas koniocelular também exercem influencia no desenvolvimento destas funções, seria possível que disfunções no sistema koniocelular estivessem gerando alguns dos sintomas do EV.

Uma vez que os cones-S levem suas projeções na área MT do córtex visual, eles estariam envolvidos no direcionamento da atenção visual. Os autores sugerem que isto poderia ter possíveis implicações no entendimento de patologias tais como a dislexia [94], e pela similaridade nos sintomas visuais com, o EV.

\subsection{Deficiência no processamento de baixo nível, na retina}

Como mencionado nas hipóteses anteriores, a hiperexcitabilidade cortical nas áreas de processamento de alto nível no córtex visual poderiam estar gerando os sintomas do EV. No entanto, seria possível que no córtex estejam chegando sinais ruidosos gerados em níveis de processamento visual mais baixos. Do mesmo modo, a hipótese de uma deficiência no sistema magnocelular explicaria alguns dos sintomas do EV, contudo, devemos lembrar que as fibras do sistema magnocelular têm origem na base do processamento visual de baixo nível, na retina. Assim, seria possível que a partir de um mal funcionamento na interação das células nas diferentes camadas da retina estejam sendo produzidos os sinais ruidosos ou deficientes que mais adiante irão fornecer informações ao processamento visual de baixo (no mesencéfalo e córtex V1) e alto nível (a partir da área V2 do córtex visual).

A baixa sensibilidade ao contraste é um sintoma comum no EV. Estudos mostram que uma alteração na transmissão sináptica das células horizontais aos fotorreceptores pode ocasionar uma diminuição na sensibilidade ao contraste na retina de vertebrados [106]. A redução do feedback que as células horizontais fornecem aos fotorreceptores pode 
gerar sensibilidade à luz e visão embaçada, sintomas amplamente relatados na SI ou EV. Assim, poderia ser plausível que defeitos nas células da retina que regulam a entrada de luminosidade nos fotorreceptores e consequentemente no nervo óptico estejam envolvidas na geração dos sintomas de aversão à luz.

Parker fez uma analise espectrométrica do desempenho das lâminas espectrais (overlays) mostrando que elas reduzem significativamente a energia da luz que entra no olho dependendo do comprimento de onda. Assim, sugeriu que a diminuição da energia da luz é a física por trás do sucesso dos filtros espectrais, e apontou que certas cores (comprimentos de onda) podem causar anormalidades eletroquímicas nos fotorreceptores, resultando em sinais eletrônicos distorcidos com alta energia transmitidos ao cérebro [154].

Barbolini et al. (2009) [28] realizaram uma analise morfocromática da mácula de pacientes fotofóbicos, com e sem enxaqueca, e grupo controle. Neste estudo, $85 \%$ dos participantes fotofóbicos com enxaqueca foram também diagnosticados com Síndrome de Irlen. O uso dos filtros espectrais levou a uma diminuição dos sintomas de EV e do Erro Total no teste Farnsworth-Munsell 100 hue ${ }^{3}$. Em comparação com os controles, a região macular dos pacientes com SI mostrou uma diminuição nos fotopigmentos vermelho, verde e azul, com um valor significativo para vermelho e azul, que se correlacionaria com uma diminuição do fotopigmento dos cones ligado à discriminação de cores. A partir deste estudo, os autores concluem que a SI parece ser uma condição hereditária relacionada a uma redução setorial dos fotopigmentos dos cones, e que os filtros espectrais podem facilitar o reconhecimento de cores e sua discriminação devido ao recrutamento de cones que funcionam corretamente.

\subsubsection{Desequilíbrio na informação fornecida pelos cones}

As células do caminho magnocelular recebem principalmente sinais de entrada dos cones-L e M, e pouco sinal dos cones-S (menos do 10\%) [47], enquanto as células do caminho Parvocelular recebem sinais de entrada dos três tipos de cones, numa distribuição mais equitativa.

Consideráveis variações individuais entre o número de cones-L e M têm sido encontradas em tricromatas ${ }^{4}[35,110]$. Quando estimada a relação entre os cones-L/M a altas

\footnotetext{
${ }^{3}$ teste utilizado em humanos, desenvolvido para testar daltonismo e capacidade de reconhecimento de cores

${ }^{4}$ Pessoas que possuem os três tipos de cones na retina
} 
frequências temporais (que estimulam o MC), esta relação difere da unidade com grande variação entre indivíduos; porém, quando estimada a baixas frequências temporais (que estimulam o PC) esta relação se mantém sempre perto da unidade [110]. Isto sugere que a sensibilidade do canal de luminância esta diretamente relacionada com as densidades relativas dos $\mathrm{L}$ e $\mathrm{M}$ cones, e que o canal cromático vermelho-verde introduz um ajuste no ganho, que compensa as diferenças entre as forças dos sinais dos cones-L/M. Kremers sugere que em altas frequências temporais a ponderação do peso dos cones poderia estar sendo completada pelas células bipolares [110] . Deste modo, e apesar das diferenças interindividuais no número de cones- $\mathrm{L}$ e $\mathrm{M}$ presentes na retina, as cores aparecem similares para a maioria dos indivíduos porque os sinais dos cones-L ou M são dimensionados para se equalizarem com o sinal do seu canal oponente, para serem levados às células dos caminhos parvo, konio e magnocelular.

O sistema de luminância (LUM) em humanos detecta o movimento rápido e o flicker; este mecanismo tem origem nas células ganglionares da retina [202]. As lesões no caminho magnocelular (MC) elevam fortemente os limiares de contraste para a detecção de movimentos rápidos e de flicker [178]. Acredita-se que o mecanismo LUM seja acromático, respondendo a uma soma neural de sinais de contraste L e M originados nos cones de comprimento de onda longa (L) e comprimento de onda média (M). No entanto, estudos de flicker em humanos mostraram que os fundos coloridos de adaptação, nos que se apresenta o estímulo visual, influenciam fortemente o mecanismo LUM [202]. Stromeyer et al., usando flicker ou alvos em movimento, mostraram que os fundos laranja e verde produzem grandes mudanças de fase opostas entre os sinais L e M, e que os deslocamentos de fase são acompanhados por grandes mudanças na proporção dos pesos de contraste L e M como uma função da frequência temporal [202]. Estas mudanças de fase acontecem nas células ganglionares de fase que formam o sistema magnocelular. Stromeyer indica que se o estímulo for apresentado num fundo laranja, a medida que é aumentada a frequência (exemplo, de 6 a 20Hz) o peso M no contraste tende a aumentar enquanto o peso L do contraste tende a diminuir [202]. Neste mesmo estudo, os estímulos foram colocados também num fundo amarelo o que anulou o deslocamento de fase L versus M (a $9 \mathrm{~Hz}$ ). Nesta cor de fundo do campo visual, nenhum movimento foi visto (embora forte movimento foi visto com os fundos de campo laranja e verde). Estes resultados indicariam que os sinais L e M têm cursos temporais similares no campo amarelo.

A via LUM baseada no sistema magnocelular mostra-se altamente plástica, uma vez que a adaptação cromática influencia a fase temporal relativa e os pesos relativos de contraste dos sinais L e M, como funções da frequência espacial e temporal. Isso pode 
causar grandes mudanças nos ajustes psicofísicos de equilíbrio, pois esses parâmetros são variados. As mudanças não refletem fatores como o número relativo de cones-L e M, mas são provavelmente causadas por uma interação das respostas do centro e da periferia das células MC. Porém, existe um campo amarelo para cada observador onde a mudança de fase relativa e as variações nos pesos de contraste relativos desaparecem [202].

Do anterior, podemos inferir que modificar a cor do campo visual afeta a resposta temporal dos sinais L e M no mecanismo de luminância. Este poderia ser o mecanismo pelo qual os filtros espectrais intervêm, modificando os pesos dos sinais L e M (e possivelmente também o sinal que gera o amarelo $(S+(L+M))$ ), equalizando assim os sinais que irão chegar no córtex visual. Teoricamente, se a equalização dos sinais L,M e $\mathrm{S}$ nas células ganglionares estão funcionando de forma correta, nenhum movimento deveria ser visto quando os estímulos são colocados em fundos de campo amarelos.

Estudos mostram que é pouco provável que os filtros espectrais afetem significativamente o caminho Parvocelular, pois os sinais de entrada que vem dos L e M cones são equalizados por este subsistema visual [148]. No entanto, o caminho magnocelular não possui tanta capacidade para realizar este tipo de equalização das entradas dos cones [46,110,169]; assim, os filtros espectrais poderiam estar ajudando nesta função. Desta forma, o processamento do sinal dos cones no magnocelular de indivíduos com EV poderia ser anormal e estar gerando os sinais ruidosos que não podem ser interpretados corretamente pelo córtex visual.

Flitcroft [75] sugeriu que o sistema visual usa mecanismos de oponência de cor e diferenças em contraste entre as três classes de cones para especificar a desfocagem e influir na acomodação. Estudos empíricos posteriormente reportaram que o modelo proposto por Flitcroft era consistente [193]. Desta forma, uma disfunção no processamento das diferenças de contraste ou de oponência de cor nas células ganglionares pode intervir no mecanismo de acomodação; o qual parece estar afetado em pessoas com EV que têm se beneficiado com uso dos filtros espectrais.

Ridder et al. [169] sugeriu que o processamento dos cones através do caminho magnocelular poderia ser anormal em sujeitos com desconforto visual, o que incrementaria o ruído neural. Para testar a hipótese foi estimada a relação entre os cones-L/M de um grupo de pessoas que apresentavam desconforto visual e um grupo controle, mediante eletrorretinogramas (ERGs). Os estímulos utilizados na pesquisa foram isolados para cada tipo de cone (L e M). Os dois grupos pesquisados apresentaram uma relação de cones-L/M 
dentro da faixa de valores considerada para pessoas normais (sem deficiências visuais) estimada por Kremers [110], ou seja, não houve diferenças estatísticas significativas na relação entre cones-L e M. No entanto, menciona-se que o fato dos ERGs terem sido realizados com estímulos a $30 \mathrm{~Hz}$ poderia ter influenciado os resultados, pois era possível que esta frequência temporal estivesse ativando seletivamente o canal visual de luminância. Então, esses resultados podem pertencer apenas à função do cone no sistema de luminância. Observando os resultados desta pesquisa poderia-se dizer que quando é medida a ativação de um tipo de cone separadamente não há diferença entre pessoas com e sem desconforto na leitura; no entanto, seria possível que as diferenças aparecessem ao medir a ativação em conjunto dos cones (que acontece por exemplo nas células ganglionares, ou inclusive no nível das células horizontais, onde os estímulos dos diferentes cones começam a interagir).

Brainard et al. [35] observaram que a relação entre os L/M cones varia consideravelmente entre duas pessoas, enquanto sua reação a estímulos de amarelo único ${ }^{5}$ foram semelhantes. Dessa forma, mostraram que o equilíbrio dos sinais dos cones-L/M (ganhos e fases das respostas fornecidas pelos L e M cones em ERGs) parecem ser similares em humanos, apesar das diferenças entre o número de cones-L e M presentes na retina. Isto, pode indicar que nestes sujeitos a capacidade de equalização funciona de forma aproximada. Mollon \& Jordan [144] mostraram que sujeitos deuteranópicos ${ }^{6}$ e protanópicos ${ }^{7}$ apresentam uma sensibilidade a estímulos de amarelo único numa faixa de 565-580nm, similar à faixa apresentada em tricromatos. Contudo, na busca bibliográfica realizada na presente pesquisa, não encontraram-se registros de experimentos que testassem a sensibilidade ao Amarelo único em pessoas com sintomas de EV ou Síndrome de Irlen. Assim, mesmo que algumas pessoas com EV tenham mostrado relações entre os L/M cones aproximadamente normais, não está bem definido se a equalização dos pesos dos cones nos caminhos parvo, konio e magnocelular destes indivíduos funciona adequadamente.

\subsection{2 ipRGCs}

Faz alguns anos pensava-se que as células ganglionares fotossensíveis só contribuíam com a parte visual não formadora de imagens, pois como mencionado na seção 1.0.1.1 as GCs que expressam melanopsina estão envolvidas nos reflexos pupilar e no ciclo circadiano. No entanto, existe uma projeção adicional das ipRGCs ao Corpo Geniculado

\footnotetext{
${ }^{5} \mathrm{O}$ amarelo único e o azul único são vistos quando o processo do vermelho-verde esta em equilíbrio e quando o processo amarelo-azul esta polarizado numa direção ou outra [144].

${ }^{6}$ daltônicos com baixa sensibilidade aos comprimentos de onda médios

${ }^{7}$ daltônicos com baixa sensibilidade aos comprimentos de onda longos
} 
Lateral que indicaria a associação das ipRGCs com a percepção visual induzida pela via de formação da imagem [235]. Estudos mais recentes têm mostrado que fibras das ipRGCs estão envolvidas em algumas funções formadoras de imagem tais como reconhecimento de contraste e de direcionalidade do estímulo.

$\mathrm{Na}$ seção 1.0.1.1 foram mencionadas algumas características e funções que foram atribuídas às ipRGCs. Esta informação encontra-se esquematizada no diagrama da figura 38.

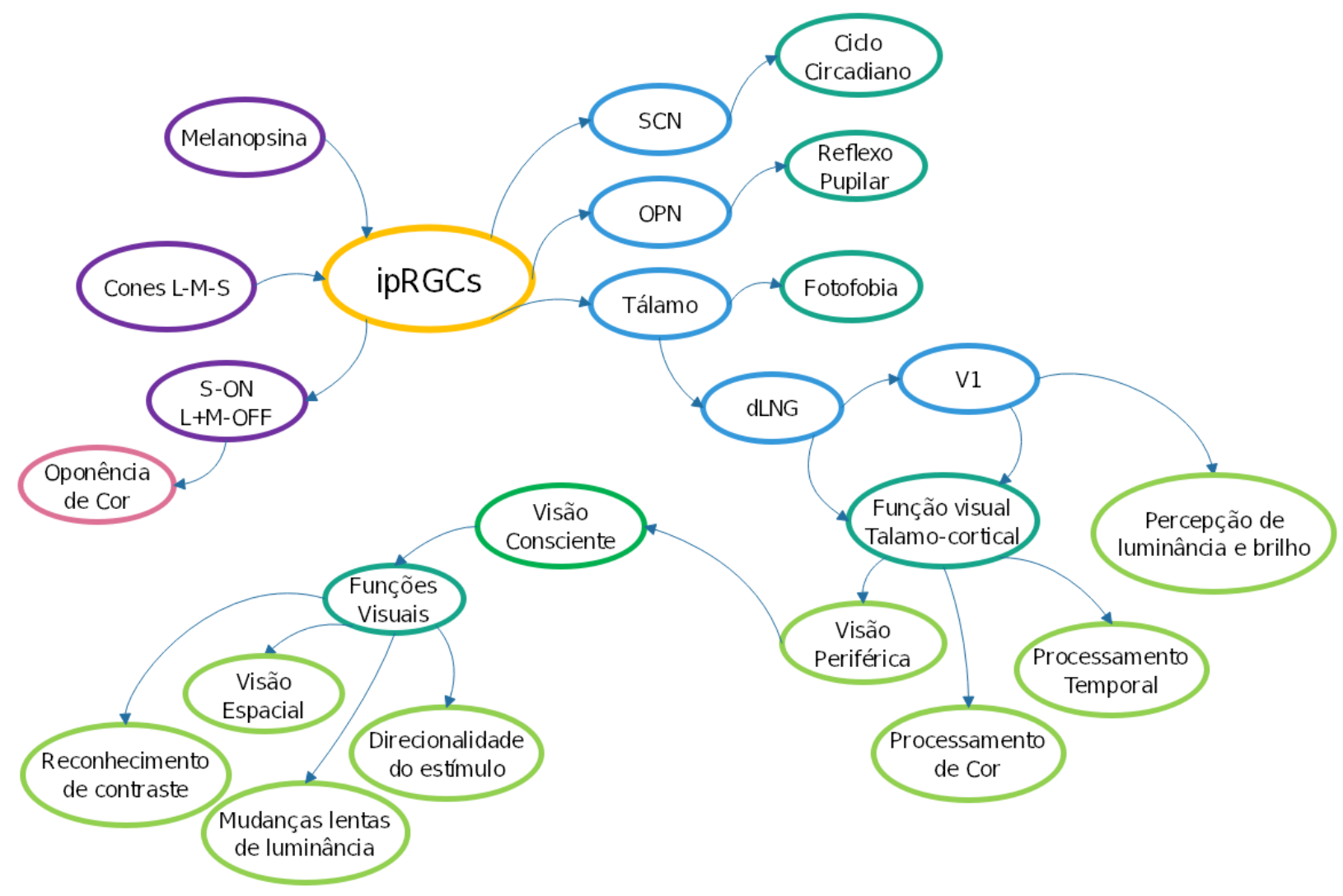

Figura 38: Esquema de características e funções das ipRGCs

Fonte: própria

Como pode ser observado, as ipRGCs estão envolvidas em processos da visão consciente que podem estar correlacionados com as funções que estão afetadas no EV, tais como sensibilidade ao contraste (contraste mediado pela informação dos cones), fotofobia, reconhecimento de direcionalidade do estímulo e visão espacial. Além disso, já que elas principalmente fazem parte da visão periférica, algum mal funcionamento poderia afetar o span de reconhecimento na leitura.

O fato de que estas células ganglionares possuam oponência de cor e tenham um pico de sensibilidade nos comprimentos de onda curtos, indicaria uma possível relação com o 
benefício dos filtros espectrais, especialmente aqueles que transmitem comprimentos de onda curtos (azuis), pois devido aos altos limiares de ativação destes fotorreceptores, os filtros poderiam estar ajudando na intensificação dos estímulos que as ativam.

De fato, os filtros azuis têm se mostrado benéficos em pacientes com enxaqueca, uma condição fortemente relacionada com a disfunção das ipRGCs [115]. Uma melhora no padrão de sono, na atenção e disposição, assim como diminuição nas dores de cabeça foram reportadas em crianças que utilizaram filtros azuis; estas melhorias foram relacionadas com uma correta ativação das ipRGCs [49]. Sobre os benefícios anteriormente mencionados, Stein propõe que a ativação das ipRGCs mediante os filtros azuis e sua ação sobre o Núcleo Supraquaismático promove uma melhoria na atenção pela ativação do caminho atencional Magnocelular-Dorsal; sugere que ao fornecer filtros azuis para crianças com problemas de atenção visual, poderia estar-se aumentando sua excitação e capacidade de concentração no texto a ser lido [198]. Na sua justificativa, Stein não contempla que as ipRGCs podem estar agindo diretamente na geração da imagem visual consciente, talvez, porque pesquisas mostrando as relações visuais formadoras de imagem em humanos das ipRGCs são recentes e ainda existem poucas.

Zele [239, 240] menciona que quaisquer alterações na função da melanopsina em pessoas com distúrbios da retina, neurologia ou cronobiologia também podem afetar a sensibilidade dos bastonetes e/ou cones. Assim, devido a ação que exercem as CG que expressam melanopsina nos demais fotorreceptores sua disfunção poderia estar criando um desequilíbrio na informação fornecida pelos cones, o qual (como anteriormente discutido) pode estar gerando alguns dos sintomas do EV.

As ipRGCs exercem influência no circuito que ativa a fotofobia e a percepção de luminância e brilho na área V1. Noseda et al. [149] sugerem que a fotofobia com enxaqueca poderia estar-se originando na retina em lugar do córtex, nos caminhos retinais que são influenciados pelos sinais dos cones, onde acontece a interação com as ipRGCs. Eles mostraram que a luz azul induz picos mais altos de intensidade nos Potenciais Evocados Visuais em pessoas com enxaqueca e fotofobia, e mencionam que alguns estudos encontraram que filtrar a luz azul reduz a frequência de enxaqueca (mas não a sensibilidade à luz) em crianças.

Observando as funções que têm sido atribuídas às ipRGCs é compreensível levantar a hipótese que sua disfunção poderiam gerar vários dos sintomas relevantes do EV, tais como Fotofobia, Dores de cabeça ou enxaqueca, baixa sensibilidade ao contraste, 
baixa percepção espacial. Além de estar afetando outros sistemas pela sua influência na oponência de cor e sua relação com os cones e os bastonetes; intervindo com isto, no contraste entre os cones-L e M. Ademais, os benefícios dos filtros espectrais poderiam ser explicados por esta mesma relação. No entanto, Wilkins [218] sugere que é muito cedo para dizer que as ipRGCs têm um papel na explicação dos efeitos da cor na leitura, mas considera o fato de que usar filtros espectrais afeta a energia de luz absorvida pelos ipRGCs e que isto pode ter consequências no ciclo circadiano.

O reflexo pupilar é uma função em grande parte controlada pelas ipRGCs [179]. Recentemente, num estudo feito por Cortéz et al. [55] utilizando a técnica Edge-light Pupil Cycle Time (PCT), que mede a integridade relativa dos caminhos da pupila aferentes e eferentes, indicaram que de acordo com a resposta da pupila é possível distinguir entre sujeitos com enxaqueca, de sujeitos com simples dores de cabeça e controles. Seria interessante realizar este tipo de experimentos em sujeitos com EV, para estabelecer se o reflexo pupilar está envolvido nos sintomas desta condição e conseguir relacionar o funcionamento das ipRGCs com o EV.

\subsection{Cores preferidas}

Nesta seção serão apresentados dados sobre a escolha de cor nos filtros espectrais (overlays e lentes) e que poderia estar indicando tal escolha.

Lembrando, os filtros espectrais em forma de overlays estão compostos por 10 lâminas translúcidas que podem ser utilizadas em forma individual ou em dupla. Na figura 30 mostra-se a cromaticidade das cores disponíveis.

Num estudo, realizado por Suttle et al. [203] sugere-se que a escolha dos filtros espectrais por parte de pessoas com EV possui pouca repetibilidade. Neste estudo feito com crianças com EV e grupo controle, os participantes escolheram a overlay mais benéfica para aliviar os seu sintomas e também foram submetidas à colorimetria intuitiva, na qual foi selecionada a mais benéfica de uma ampla gama de configurações de iluminância cromática. Cerca de metade dos participantes (10 pessoas) escolheram a mesma ou similar sobreposição de cores (overlays) nas duas ocasiões, enquanto o resto dos participantes (11 pessoas) escolheram uma cor completamente diferente. Assim, propõem que as pessoas com EV dificilmente encontrarão exatamente a mesma cor ideal para ela em ocasiões diferentes, e levantam questões sobre a necessidade de precisão da cor em lentes e overlays 
para tratar o EV.

Aleci [18] faz algumas considerações que vale a pena mencionar em relação às análises feitas por Suttle. Ele nota que na escolha das overlays em 94,5\% das comparações classificadas como 'iguais' ou 'similares', as matizes de escolha pertenciam àqueles com transmissão máxima no lado esquerdo do espectro de comprimento de onda (isto é, azul, água, verde menta, verde lima), e em apenas um caso $(5,6 \%)$ foi escolhido uma overlay roxa; por sua vez, em 64,7\% das comparações classificadas como "diferentes" as matizes de escolha foram aquelas pertencentes àqueles com transmissão máxima no lado direito do espectro (amarelo, laranja), enquanto em $35,3 \%$ dos casos os filtros selecionados pertenciam ao outro espectro de comprimento de onda. Ele sugere que baseados nos dados da pesquisa de Suttle et al., a escolha da tonalidade é altamente repetível, em indivíduos que sofrem de EV e que se beneficiam de filtros de transmissão de comprimento de onda curto. Em vista do anterior, Aleci propõe que uma alta repetibilidade pode ser encontrada em pessoas com EV que acham benéficos os filtros de comprimento de onda curto, porque estes podem ajudar a equilibrar a excitação cortical modificando as respostas magnocelulares e parvocelulares.

Num estudo feito por Conway et al. [54] mostrou-se que existe alguma associação entre a escolha da cor das overlays e o gênero do indivíduo; embora, esta correlação não se mantenha na escolha dos lentes espectrais. Assim, os homens tenderiam a escolher cores perto do azul e verde e as mulheres perto do rosa ou roxo. O autor sugere que uma causa para essa diferença entre lentes e overlays é que a lente tem que ser usada em todo momento, e a escolha da cor poderia ter um motivo estético.

Em várias pesquisas $[28,49,62,77,87,89,95,160,168,180,188,203,219]$ a maioria das escolhas na cor no filtro encontram-se entre azul e amarelo. Este ponto foi notado também por Stein, baseado no artigo de Wilkins [219], do qual observa que as cromaticidades dos filtros que se mostram efetivos agrupam-se principalmente em torno do amarelo ou do azul, e que existe pouca evidência que aponte a que seja requerida uma ampla faixa de cores nos filtros para gerar algum efeito de alivio em pessoas com EV e dificuldades na leitura [195]. Segundo Stein então, a evidência para exigir uma grande variedade de cores nos filtros não é muito grande, pois as cores individuais escolhidas geralmente se agrupam em torno de amarelo e azul, e se a teoria do déficit no Magnocelular estiver correta, apenas amarelo e azul devem ser suficientes para aliviar os sintomas.

Chase et al. [45] mostrou numa série de experimentos que a luz vermelha afeta o 
correto funcionamento do Magnocelular, como mostrado em outras pesquisas [37,125]; e que portanto, o uso de filtros azuis ou cinzas pode ser benéfico para melhorar processos como a leitura. Manifesta que o importante não é a presença do filtro azul, mais sim, a ausência dos comprimentos de onda longos (vermelhos). Isto poderia explicar também por que os filtros de cor azul apresentam uma melhoria na leitura dos indivíduos do grupo controle, pois ao estar favorecendo a função do magnocelular, informações tais como onde levar os olhos na próxima sacada podem ficar mais rápidas, fazendo mais rápido o processo de leitura. No estudo realizado por Solan et al. tanto o grupo de indivíduos com dificuldades na leitura como o grupo controle apresentaram melhoria no teste de leitura mediante o uso de filtros azuis [188]. Clisby et al. [49] especularam que os filtros azuis resultaram ser benéficos porque cortam os comprimentos de onda longos em crianças que teriam um número anormalmente grande de cones-S que estão pobremente ativados.

Basicamente, a cromaticidade dos filtros preferidos pelos indivíduos testados nas pesquisas antes mencionadas encontram-se na área delimitada pela linha vermelha na figura 39. As cromaticidades rosas e roxas fazem parte da minoria das escolhas. Esta imagem pertence ao estudo de Drew et al., nela representaram as cromaticidades escolhidas pelos participantes do estudo, onde as pessoas com elevado desconforto visual preferiram cromaticidades perto do azul e amarelos, sendo que as pessoas com menor desconforto visual escolheram cromaticidades perto do verde e o amarelo.

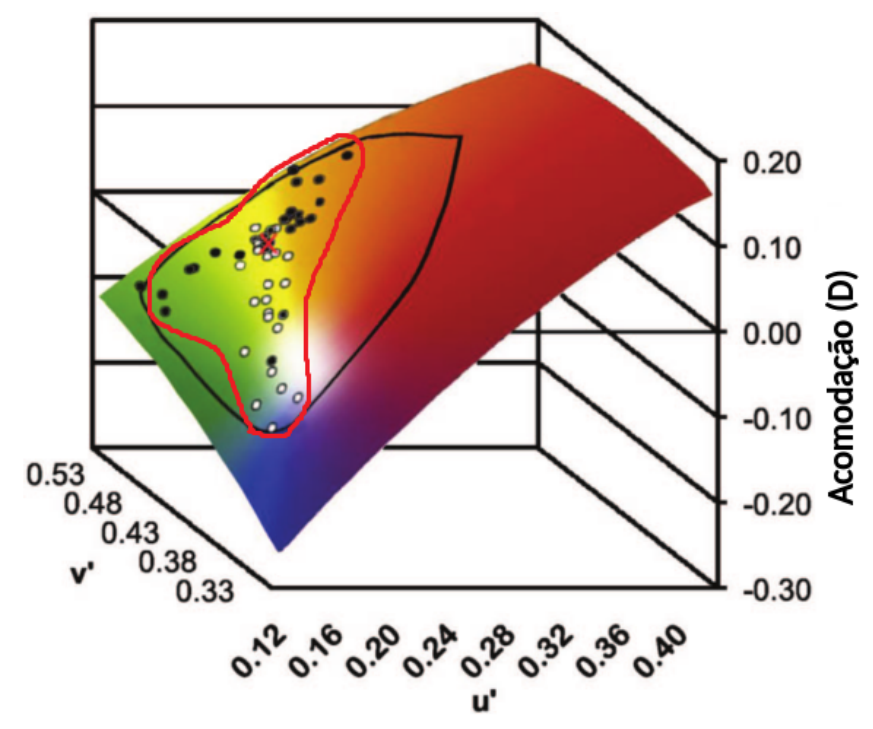

Figura 39: Preferências de cor no estudo de Drew et al. (2012). Os círculos pretos mostram as cromaticidades escolhidas pelos indivíduos com baixo desconforto visual e los círculos brancos dos indivíduos com elevado desconforto visual

Adaptado de Drew (2012) [62]

Os filtros na faixa dos verdes e amarelos permitem a transmissão de comprimentos 
de onda de médios a semi-longos, o qual permite tanto a ativação dos cones-M como dos cones-L. Isto poderia indicar que o efeito que geram estes filtros é uma ajuda na equalização dos pesos dos cones [160]. Adicionalmente, diminuir a intensidade da energia transmitida à retina ajuda a melhorar o desempenho na leitura (efeito gerado com os filtros cinzas), da mesma forma, o uso de filtros azuis (que filtram comprimentos de onda curtos) faz mais eficiente o processo de leitura [188]. O anterior poderia indicar, que melhorar o compromisso dos cones-L/M, mediante o uso de filtros amarelos ou diminuir sua função, mediante o uso de filtros azuis permite diminuir o desconforto na leitura.

Stein [198] presume que os filtros amarelos são uma forma muito mais conveniente de melhorar a função das células do magnocelular, pois este tipo de filtros ativam seletivamente as células do Magno, já que recebem a maior parte do seu sinal de entrada dos cones vermelho e verde; os quais são melhor estimulados pela luz amarela. Estes filtros amarelos filtram os comprimentos de onda mais curtos, azuis, na luz branca e, portanto, fazem com que as pupilas se dilatem. Isso, por sua vez, faz com que a quantidade de luz amarela que entra no olho aumente, e assim, a atividade das células Magnocelulares é aumentada em cerca de $2 / 3$. O efeito antes mencionado seria o mesmo que estaria por trás da melhoria na sensibilidade ao contraste dos esquiadores que usam lentes amarelas.

Em contraste aos estudos antes mencionados, Palomo Álvarez et al. encontraram que os filtros amarelos não produziram nenhum efeito significativo na acomodação, na velocidade na leitura, nem na visão binocular de crianças com deficiência na leitura [152].

Stein [198] observou também que uma considerável parte de disléxicos e deficientes na leitura se beneficiam mais utilizando filtros que transmitem tons azuis profundos; quase o oposto dos amarelos. Esses filtros azuis provavelmente estariam agindo na melhoria da atenção visual e da concentração de uma maneira diferente, ativando o conjunto de células ganglionares da retina que contêm melanopsina (ipRGCs). Este pigmento é mais sensível à luz azul, e as células que o contêm projetam seus axônios principalmente no núcleo supraquiasmático (SCN) no hipotálamo. Este núcleo contém o relógio principal do corpo que nos acorda de manhã, promove o sono à noite e sincroniza todos os ritmos diurnos que temos, como temperatura corporal, frequência cardíaca, pressão arterial e flutuações hormonais. O sinal luminoso azul do amanhecer e a entrada do sinal das ipRGCs no SCN promovem a excitação matinal ativando a via atencional Magnocelular-Dorsal. Ao dar filtros azuis para crianças com problemas de atenção visual, pode-se estar aumentando sua excitação e capacidade de concentração no texto a ser lido. 
Stein afirma que a experiência de estudar vários milhares de crianças com problemas de leitura lhe permite concluir que aqueles que sofrem de visão embaçada devido à desfocagem, juntamente com a convergência reduzida e visão dupla (diplopia) podem se beneficiar mediante o uso de filtros amarelos; e que aqueles que veem palavras e letras que parecem se mover, tremer ou pular devido ao seu aparente rápido movimento aleatório, e que também tendem a perder a concentração e sofrer de dores de cabeça ou cansaço visual quando tentam ler, podem se beneficiar mais usando filtros azuis. 


\section{PARTE III}

METODOLOGIA, RESULTADOS E DISCUSSÃO 


\section{METODOLOGIA}

Um dos objetivos desta pesquisa é compilar informação suficiente para que quem estiver interessado no tema pudesse compreender de que se trata esta condição visual, qual é o tratamento atualmente disponível, como se faz o seu diagnóstico, e quais mecanismos estão possivelmente envolvidos na geração dos sintomas. Este objetivo foi desenvolvido na parte II desta tese: revisão bibliográfica.

A partir da revisão bibliográfica puderam ser apresentados os diversos sintomas do EV e quais hipóteses têm sido formuladas para explicar tais fenômenos. Adicionalmente, descreveu-se como os filtros espectrais poderiam estar desenvolvendo seu papel como tratamento terapêutico.

Com base nos sintomas e hipóteses compiladas, neste capítulo serão apresentados os modelos matemáticos, conhecidos, que descrevem o funcionamento de alguns mecanismos visuais para desenvolver modelos computacionais que simulam o comportamento de alguns subsistemas do sistema visual em indivíduos com e sem EV. Modificações nos parâmetros dos modelos computacionais permite ilustrar o que acontece quando o correto funcionamento do subsistema é alterado, gerando distorções na imagem processada.

O diagrama na figura 40 esquematiza a relação entre os modelos desenvolvidos, as funções celulares que simulam e os sintomas que poderiam estar sendo gerados.

Os modelos computacionais implementados a partir dos modelos matemáticos conhecidos foram desenvolvidos no software MATLAB.

\subsection{Modelo da Retina - retina.m}

Para simular a interação das células horizontais na Retina foi desenvolvido o algoritmo retina.m. O modelo para realizar este algoritmo originou-se do trabalho do pesquisa- 


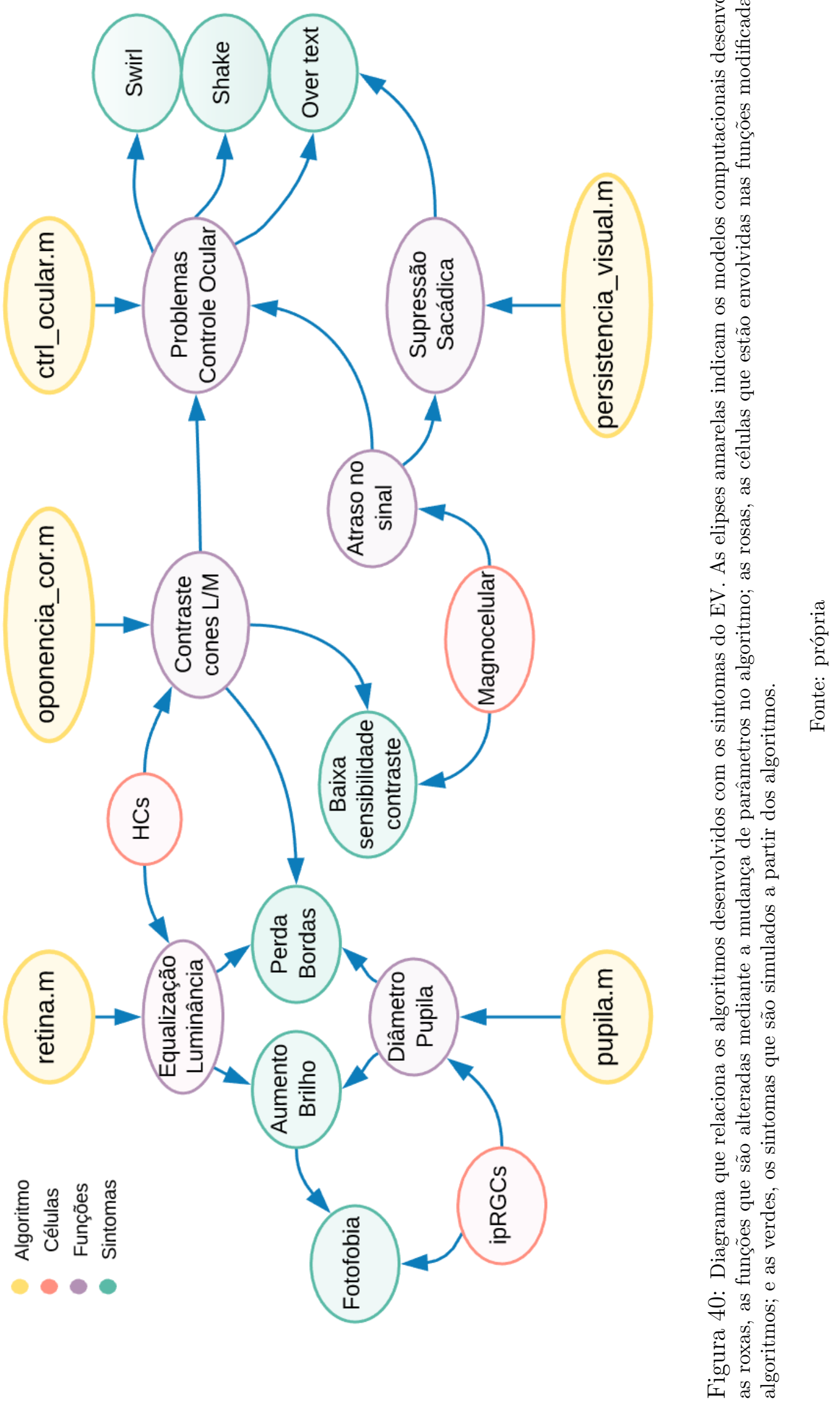


dor Jeanny Herault, e está descrito no artigo Using Human Visual System modeling for bio-inspired low level image processing do pesquisador Alexandre Benoit [31]. O modelo consta de um filtro de compressão logarítmica, que simula a adaptação lumínica gerada pelos fotorreceptores e um filtro espaço-temporal não-separável que simula os dois principais canais de informação da retina: A visão foveal para a visão com detalhes - Caminho Parvocelular; e a visão periférica para a detecção sensível de sinais transitórios (movimentos) - Caminho Magnocelular.

Este modelo da retina não é um modelo completo, mas apresenta propriedades que possibilitam modificar algumas características da retina. O modelo representa as propriedades espaciais das camadas OPL e IPL da retina. Como visto no capítulo de Fisiologia da visão 1 na camada OPL interagem os fotorreceptores, as células horizontais e as células bipolares, onde os sinais de saída desta camada seguem para as células ganglionares na camada IPL.

Na figura 41 mostra-se o diagrama com os blocos de filtragem pelos que deve passar a imagem de entrada até chegar na saída nas células ganglionares. Na imagem, os operadores BipON e BipOFF modelam a ação das células bipolares que dividem a saída da OPL em dois canais, On e OFF. Com a informação de contornos das saídas BipON e BipOFF da camada OPL, na camada IPL são destacados localmente os contornos e é melhorado o contraste pela compressão ganglionar que acontece no bloco CgP - Parvo.

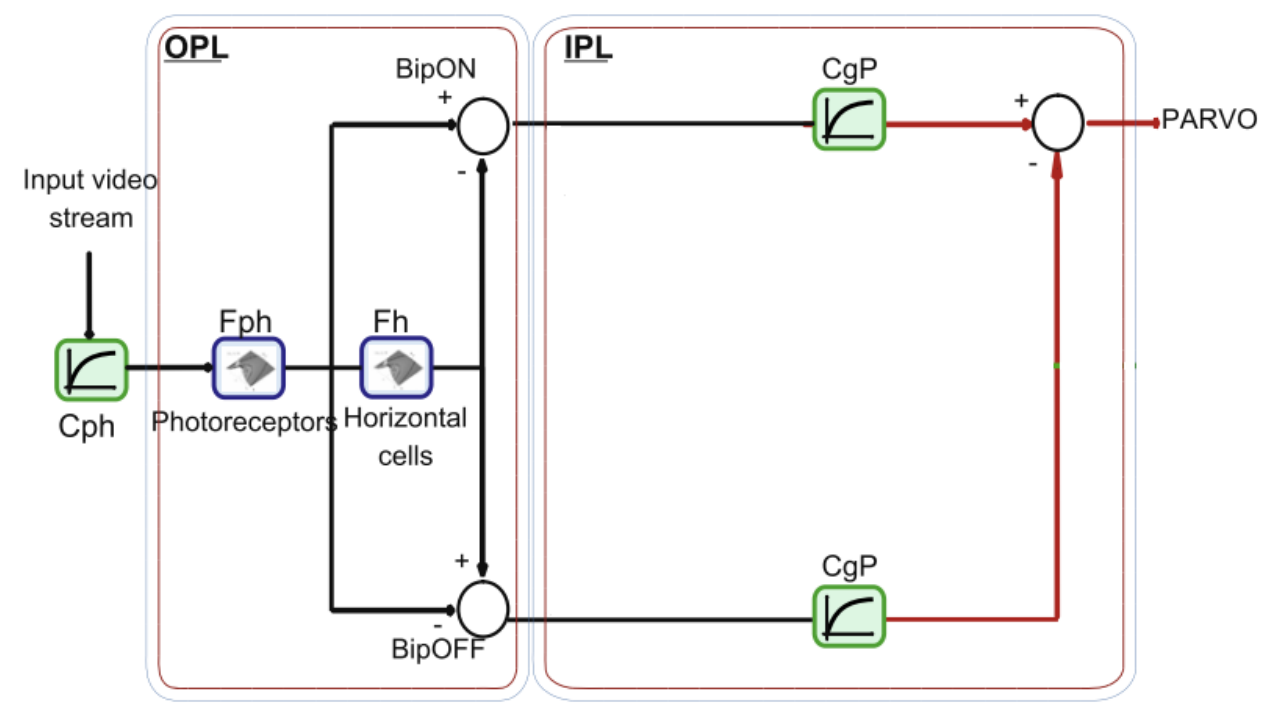

Figura 41: Arquitetura geral do modelo da retina proposto por A. Benoit Fonte: Benoit (2010) [31]

O filtro $F_{O P L}$ (figura 42) tem um efeito de filtragem espacial passa-banda em frequências temporais baixas, um amplo efeito de filtragem temporal passa-banda para baixas frequências 
espaciais, um efeito passa-baixa para altas frequências temporais e um efeito passa-baixas para altas frequências espaciais. O filtro OPL então tem a capacidade de remover o ruído espaço-temporal e realçar os contornos.
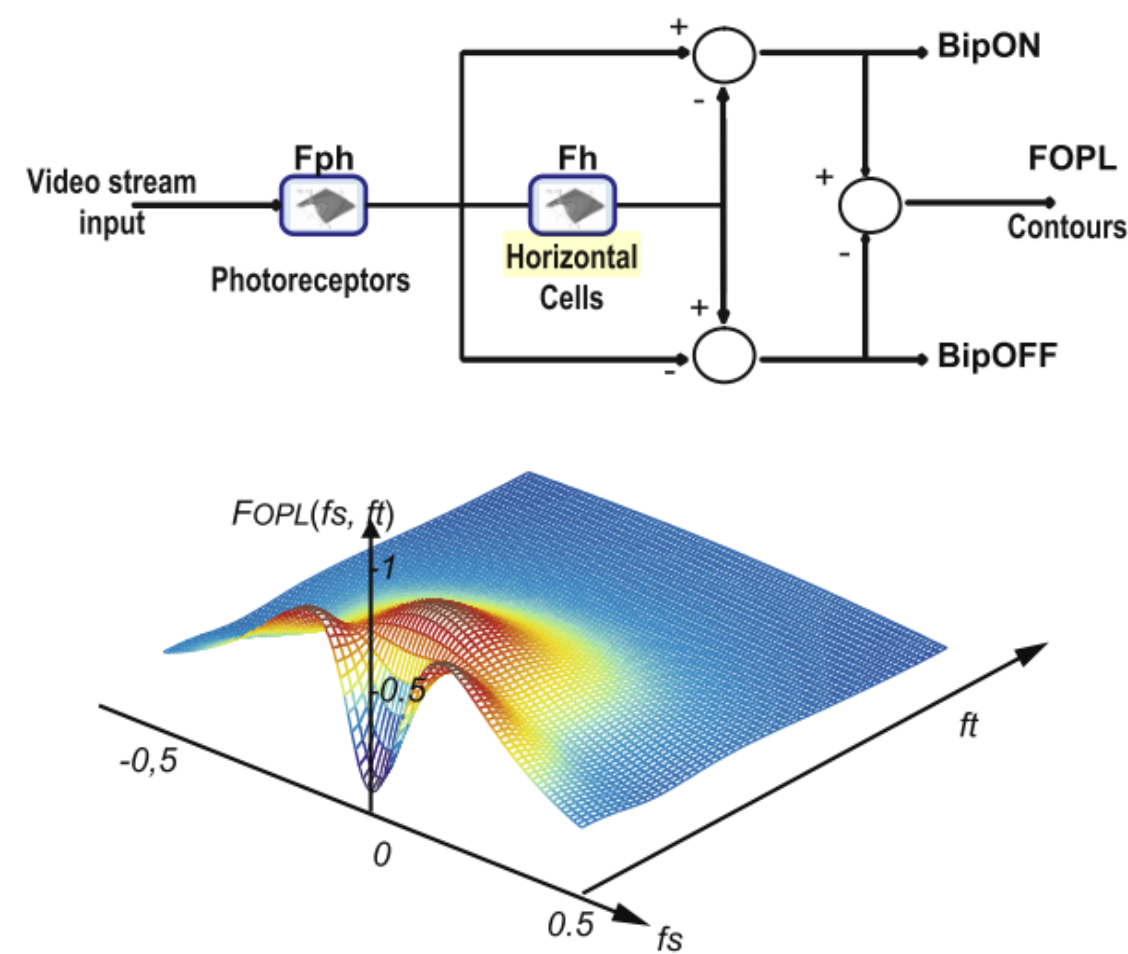

Figura 42: Filtro OPL e o gráfico da sua função de transferência

Fonte: Benoit (2010) [31]

As interações da camada OPL foram modeladas como um filtro espaço-temporal. A função de transferência do filtro esta representada pela equação 5.1, onde $F_{O P L}$ é a filtragem na camada OPL, $F_{p h}$ a filtragem nos fotorreceptores e $F_{h}$ a filtragem nas células horizontais com $f_{s}$ e $f_{t}$ sendo a frequência espacial e temporal, respectivamente. O filtro pode ser considerado como a diferença entre dois filtros espaço-temporais que modelam a rede de fotorreceptores e células horizontais na retina [31].

$$
F_{O P L}\left(f_{s}, f_{t}\right)=F_{p h}\left(f_{s}, f_{t}\right) \cdot\left[1-F_{h}\left(f_{s}, f_{t}\right)\right]
$$

onde

$$
F_{p h}\left(f_{s}, f_{t}\right)=\frac{1}{1+\beta_{p h}+\alpha_{p h} .\left(1-\cos \left(2 \pi f_{s}\right)\right)+j 2 \pi \tau_{p h} f_{t}}
$$




$$
F_{h}\left(f_{s}, f_{t}\right)=\frac{1}{1+\beta_{h}+\alpha_{h} \cdot\left(1-\cos \left(2 \pi f_{s}\right)\right)+j 2 \pi \tau_{h} f_{t}}
$$

O parâmetro $\beta_{p h}$ é o ganho do filtro $F_{p h}, \beta_{h}$ é o ganho do filtro $F_{h}$. $\tau_{p h}$ e $\tau_{h}$ são as constantes da filtragem temporal que permitem que o ruído possa ser minimizado. $\alpha_{p h}$ e $\alpha_{h}$ são as constantes da filtragem espacial: $\alpha_{p h}$ configura a frequência de corte superior e $\alpha_{h}$ a frequência de corte inferior.

A saída da rede de células horizontais $\left(F_{h}\right)$ contém a imagem das frequências espaciais mais baixas. Este parâmetro representa a luminância local $L(p)$.

Os fotorreceptores têm a habilidade de ajustar a sua sensibilidade de acordo à luminância da sua vizinhança, mediante mecanismos de feedback nos que intervêm as células horizontais e bipolares. Isto é modelado pela relação de Michaelis-Menten a qual é normalizada para uma faixa de luminância entre 0 e $\operatorname{Vmax}$ (equações 5.4 5.5).

$$
\begin{gathered}
C(p)=\frac{R(p)}{R(p)+R o(p)} \cdot V \max +R o(p) \\
R o(p)=V o . L(p)+V \max (1-V o)
\end{gathered}
$$

Nesta relação, a luminância ajustada dos fotorreceptores $C(p)$ depende da luminância atual $R(p)$ e do parâmetro de compressão $R o(p)$ o qual esta linearmente vinculado à luminância local $L(p)$ da vizinhança do fotorreceptor $p$. A luminância local $L(p)$ é estimada aplicando um filtro espacial passa-baixa à imagem de entrada. Esta filtragem passa-baixa é realmente realizada pela próxima rede celular: as células horizontais. Deste modo, a modificação dos parâmetros das células horizontais afeta a luminosidade da imagem e a capacidade de reconhecer bordas.

Na camada IPL da retina, as células amácrinas são modeladas mediante um filtro temporal passa-alta [31], o qual realça as áreas onde ocorrem mudanças em espaço e tempo. No diagrama 41 as células amácrinas (A) estão conectadas com as células bipolares (BipON e BipOFF) e as células ganglionares Parasol. Assim como no Parvocelular, as células ganglionares realizam uma compressão local do contraste (Compressão ganglionar Magno - CgM) e também agem como filtro espacial passa-baixa (Filtragem ganglionar Magno-FgM) devido ao sua extensa área de conexões. A saída é uma filtragem temporal passa-alta dos contornos da imagem. Desta maneira, os contornos móveis com baixa 
frequência espacial são extraídos e realçados; especialmente os contornos perpendiculares à direção do movimento [31].

Desta forma, a retina é simulada mediante um a série de filtros que representam a interação entre as diferentes células das suas camadas, onde o comportamento celular pode ser modificado a partir da alteração dos parâmetros dos filtros. A seguir, são explicados em detalhe os blocos no diagrama da figura 41 e sua relação com as equações 5.1 à 5.5.

Bloco Cph Neste bloco o parâmetro $V o_{p h}$ muda a sensibilidade da adaptação à luminância local dos fotorreceptores. Neste parâmetro, valores perto de 1 permitem uma elevada compressão logarítmica da luminância. Valores perto do zero deixam uma sensibilidade mais linear. Se ajustado em colaboração com o parâmetro de sensibilidade das células ganglionares $\left(V_{g P}\right)$ do bloco $\mathrm{CgP}$, as imagens podem ter muito contraste, qualquer que seja a luminância local.

Bloco Fph Neste bloco podem ser mudadas a constante temporal $\left(\tau_{p h}\right)$ e a constante espacial $\left(\alpha_{p h}\right)$ do filtro passa-baixa na entrada da retina. Um valor alto de $\left(\tau_{p h}\right)$ gera uma efeito de suavização temporal forte, ou seja, objetos que estão se movimentando podem desaparecer, enquanto objetos estáticos são favorecidos. $\left(\alpha_{p h}\right)$ é constante espacial relacionada à filtragem passa-baixa de primeira ordem realizada pelos fotorreceptores.

Bloco Fh Neste bloco, os parâmetros configuram a rede neural conectada aos fotorreceptores e as células horizontais. Aqui é modulada a sensibilidade dos fotorreceptores e completado o processamento do spectral whitening (parte do efeito passa-banda que favorece o realce dos detalhes).

$\beta_{h}$ é o ganho da rede de células horizontais. Este parâmetro pode ser colocado em zero quando focados na extração de detalhes e não na luminância média da imagem. Contudo, se quiser manter alguma luminosidade, é indicado deixar algumas baixas frequências espaciais passar no sistema, e ajustar este parâmetro acima de zero. $\tau_{h}$ é a constante temporal do filtro temporal passa-baixa que suaviza os dados de entrada.

$\alpha_{h}$ é a constante espacial do filtro passa-baixa das células horizontais. Especifica a mínima frequência espacial que é mantida. Visualmente, um alto valor deixa as frequências espaciais muito baixas para serem processadas e deixa efeitos de halo. Baixos valores diminuem estes efeitos, mas este valor não pode ser menor que o do parâmetro $\alpha_{p h}$. 


\begin{tabular}{|c|c|c|}
\hline Parâmetro & Realistas sem EV & Realistas com EV \\
\hline$V o_{p h}$ & 0.7 & 0.7 \\
$\alpha_{p h}$ & 0.53 & 0.53 \\
$\tau_{p h}$ & 0.9 & 0.9 \\
$\beta_{p h}$ & 0 & 0 \\
$V o_{g P}$ & 0.9 & 0.9 \\
$\alpha_{h}$ & 7 & 7 \\
$\tau_{h}$ & 0.5 & 0.5 \\
$\beta_{h}$ & 0.3 & 20 \\
\hline
\end{tabular}

Tabela 2: Parâmetros utilizados no algoritmo retina.m.

Assim, esses dois parâmetros de frequência espacial especificam a banda de frequências espaciais cuja informação passa pela retina.

Bloco CgP Neste bloco, o parâmetro $V o_{g P}$ especifica a força da adaptação final local que acontece na saída. Este parâmetro configura-se entre 0 e 1. Baixos valores tendem a dar uma resposta linear, enquanto valores altos reforçam as áreas de baixo contraste.

\subsection{Parâmetros}

Uma configuração de parâmetros que simulam o comportamento real da retina humana foram descritos por Jeanny Herault no livro: Vision: Images, Signals and Neural Networks- Models of Neural Processing in Visual Perception (Progress in Neural Processing) [96]. No artigo de Benoit [31] também são especificados os parâmetros realistas que simulariam o correto funcionamento da retina humana. Estes foram usados no algoritmo retina.m e são especificados na tabela 2 .

Como pode ser visto da tabela 2 o único parâmetro que muda entre as duas configurações (para uma visão 'normal' e uma com EV) é o $\beta_{h}$ (ganho do filtro das células horizontais. Estimado pela autora desde trabalho). Desta forma, modificando o ganho das células horizontais, uma falha na adaptação da luminância mediada pelas células horizontais está sendo simulada. Com isto, toda a luminosidade da imagem se mantém e se perde parte do efeito de contraste e em consequência, a função de reconhecimento de bordas se vê afetada.

Nesta simulação, o parâmetro $f_{t}$ das equações 5.2 e 5.3 foi colocado igual a zero, já 
que foi analisada uma única imagem estática.

\subsubsection{Imagens de entrada}

Vários autores descreveram que os indivíduos com EV são mais suscetíveis e experimentam desconforto ao observar padrões com frequências espacias entre 2 a 4 cpd $[51,67,216]$. Assim, um fragmento do artigo científico "The Effect of Colored Lenses on the Visual Evoked Response in Children With Visual Stress" por Riddell et al. (2006) [168] foi utilizado como imagem de entrada no algoritmo (ver figura 43). Nesta imagem pode-se observar que o texto é relativamente pequeno e com uma frequência espacial semelhante à grade 2 do teste de Pattern Glare (figura 33). Esta é a típica imagem que poderia gerar desconforto na leitura [67].

\footnotetext{
visual perception now termed "Meares-Irlen syndrome." ${ }^{1-3}$ Anecdotal reports of the success of her tinted lenses were met th skepticism justified by the lack of scientific evidence. Reitly, however, Wilkins and coworkers ${ }^{4,5}$ developed an alternae method of prescribing colored glasses. The method has the vantage that colors are searched systematically and comprehenely, and an optimal tint is provided with minimal absorbance of ht. Central to the method is a simple optical device (Intuitive lorimeter, Cerium Visual Technologies, Tenterden, Kent, UK) it optimizes the tint while the eyes are color-adapted. The hue $\mathrm{d}$ saturation are alternately adjusted so as to reduce perceptual tortions to a minimum with colored light of an optimum chrotticity. Tinted trial lenses can be selected that match the chrotticity of the optimal colored light and provide a spectral match that obtained when the lenses are worn under conventional IE type F3) fluorescent lighting. In a double-masked trial, pants reported fewer episodes of headaches and eye strain when
}

Figura 43: Imagem de entrada no algoritmo retina.m. Texto com frequência espacial média (ver seção de Pattern Glare)

Fonte: "The Effect of Colored Lenses on the Visual Evoked Response in Children With Visual Stress" por Riddell et al. (2006) [168]

Aumentando o tamanho do texto na imagem de entrada, se está diminuindo sua frequência espacial, o que em teoria, faria que os observadores não sentissem tanto ou nenhum desconforto ao olhar para este arranjo de frequências. Em consequência, o tamanho do texto da imagem 43 foi incrementado (e sua frequência espacial diminuída) e igualmente utilizado como imagem de entrada no algoritmo retina.m. Esta imagem pode ser vista na figura 44 . 


\begin{abstract}
however, Wilkins and coworkers ${ }^{4,5}$ develop $\epsilon$ thod of prescribing colored glasses. The $m \epsilon$ age that colors are searched systematically anc and an optimal tint is provided with minimal : Sentral to the method is a simple optical dev neter, Cerium Visual Technologies, Tenterde timizes the tint while the eyes are color-adap uration are alternately adjusted so as to redu ons to a minimum with colored light of an of y. Tinted trial lenses can be selected that ma $y$ of the optimal colored light and provide a s] obtained when the lenses are worn under
\end{abstract}

Figura 44: Imagem de entrada no algoritmo retina.m. Texto com frequência espacial baixa (ver seção de Pattern Glare)

Fonte: The Effect of Colored Lenses on the Visual Evoked Response in Children With Visual Stress"por Riddell et al. (2006) [168]

\title{
5.3 Modelo da dilatação da pupila - pupila.m
}

As células ganglionares intrinsecamente fotossensíveis projetam no centro de controle pupilar no pretectum cerebral. As respostas pupilares são transientes e possuem certa latência, a qual pensa-se está dirigida por um mecanismo simples que envolve uma interação não-linear com os sinais dos cones [208].

A pupila é a principal abertura pela qual o estímulo visual chega no interior do olho. Portanto, sua dilatação está relacionada à quantidade de luz que chega na retina. $\mathrm{O}$ funcionamento do reflexo pupilar tem sido modelado, e algoritmos computacionais cada vez mais elaborados têm sido desenvolvidos para simular a dilatação pupilar sob vários estímulos $[97,153]$.

Neste trabalho, procura-se ilustrar a condição de iluminação da imagem que deve ser processada pela retina sob diferentes níveis de abertura da pupila. Para isto, o modelo matemático da dilatação da pupila proposto por Moon e Spencer [146], o qual é a base de outros modelos com características mais complexas, foi utilizado no algoritmo computacional pupila.m.

O modelo de Moon e Spercer prediz o tamanho da pupila como uma função da intensidade da luz baseado em medidas experimentais que foram feitas para vários níveis de 


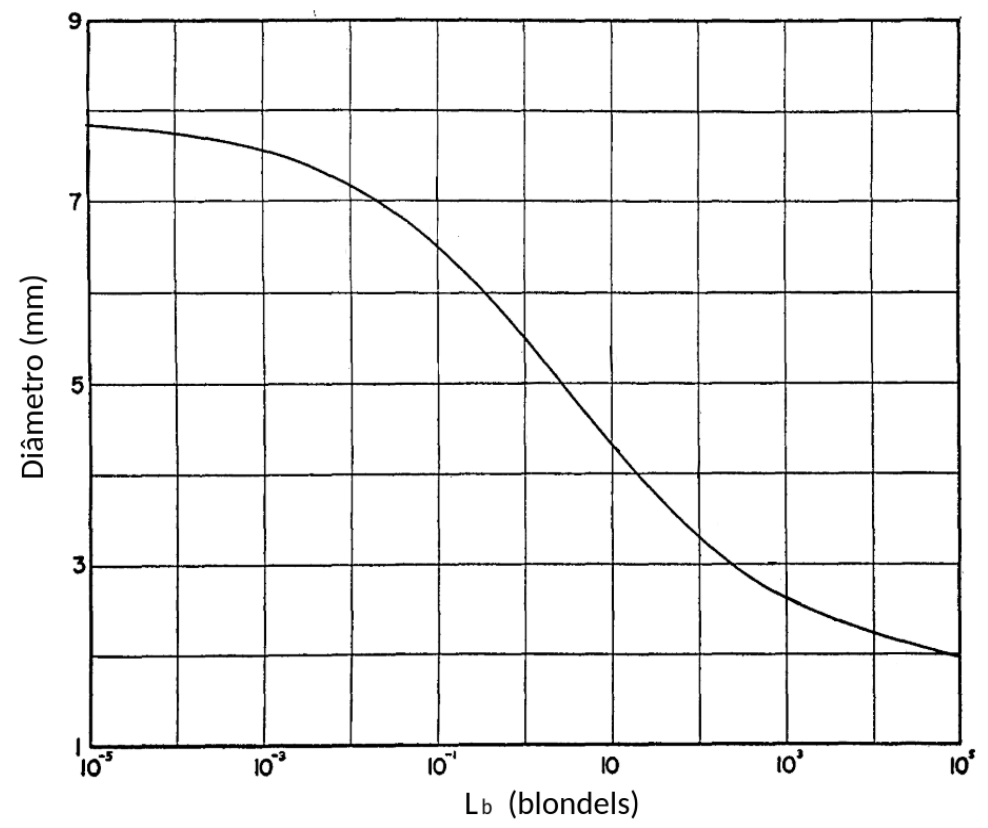

Figura 45: Curva que descreve a mudança no tamanho da pupila

Fonte: Adaptado de Moon e Spencer (1944) [146]

iluminação, esperando a estabilização da pupila. Assim, este modelo descreve o comportamento da pupila num estado de equilíbrio.

A equação proposta por Moon e Spencer esta descrita na equação 5.6, onde $D$ é o diâmetro da pupila que varia de 2 a 8 milímetros, e $L_{b}$ é o nível de iluminação do campo visual que varia de $10^{5}$ blondels nos dias de sol a $10^{-5}$ blondels em noites escuras. A curva que descreve a mudança no diâmetro da pupila pode ser vista na figura 45

$$
D=4.9-3 \tanh \left[0.4\left(\log _{10}\left(L_{b}\right)-0.5\right)\right]
$$

Segundo a norma brasileira NBR 5413 que trata a Iluminância de Interiores [9], em sala de aula a intensidade da iluminação deve estar entre 200-500 lux ( 1 lux $=1$ lumen $/ \mathrm{m}^{2}$ ). Seguindo a curva da figura 45 para 500 lux $=1570,8$ blondels, o tamanho da pupila seria igual a $2.5221 \mathrm{~mm}$. Portanto, segundo a fórmula de Moon e Spencer, em sala de aula sob essa condição lumínica a maioria das pessoas deveriam possuir um diâmetro pupilar de aproximadamente 2,5mm. Desta forma no algoritmo, 2,5 $\mathrm{mm}$ é estabelecido como o diâmetro referência da pupila. 


\subsubsection{Imagens de entrada}

A imagem 46 é uma das imagens utilizadas como imagem de entrada no algoritmo e está disponível na base de dados pública BSDS500 fornecida por Arbelaez e colaboradores $[25]$.

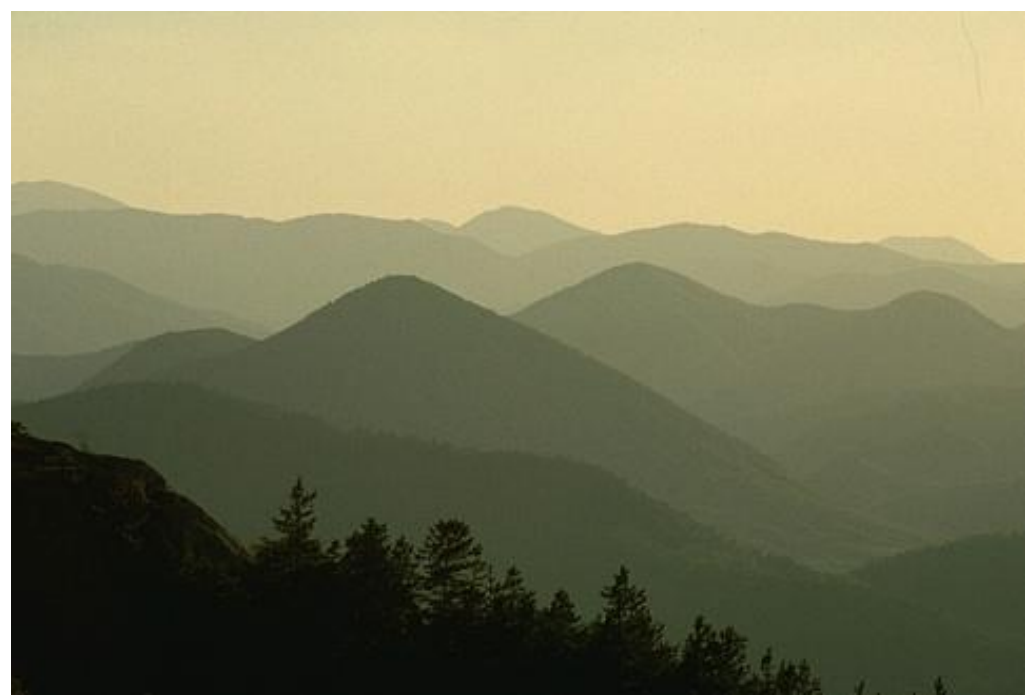

Figura 46: Imagem de entrada no algoritmo - Paisagem com montanhas sobrepostas Fonte: Base de dados BSDS500, imagem número 55067 [25]

No diâmetro referência da pupila $(2,5 \mathrm{~mm})$ a resposta do algoritmo é apresentada na figura 47. Esta seria a luminância que estaria entrando na retina de um indivíduo com dilatação normal da pupila.

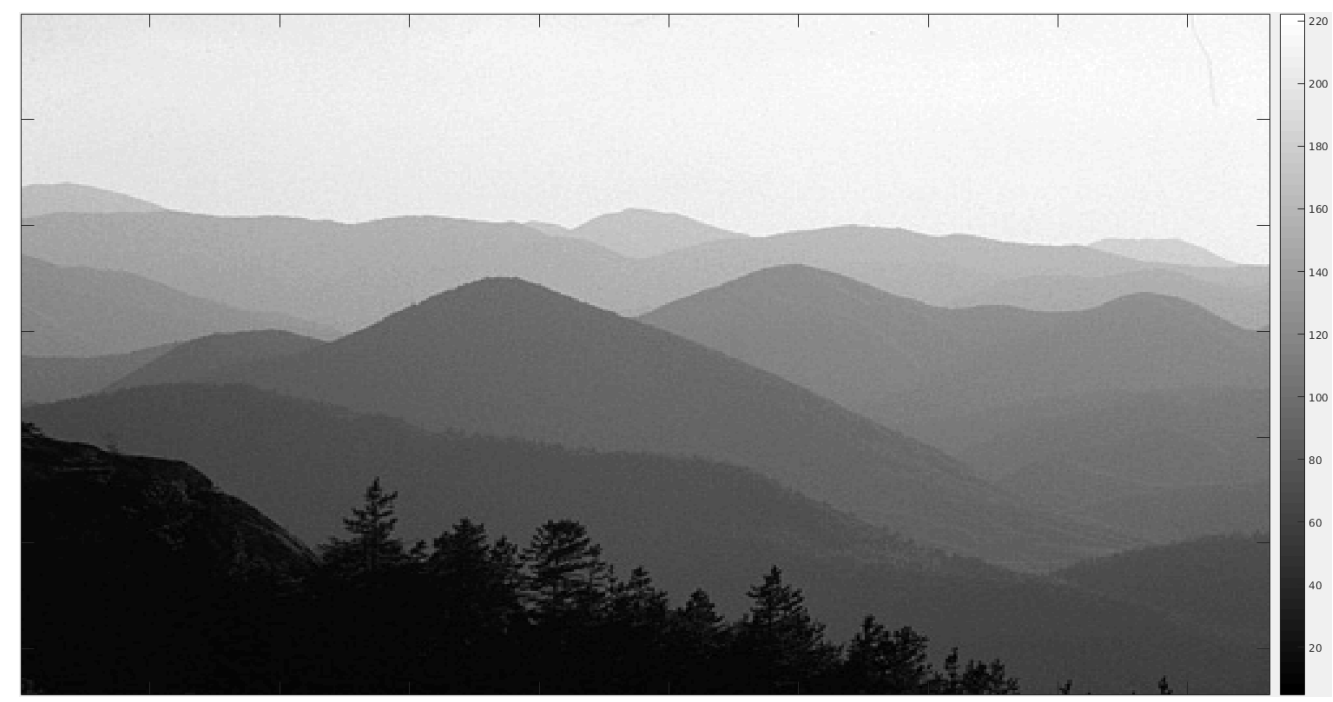

Figura 47: Imagem adquirida com o diâmetro e a luminância de referência.

$$
\text { Fonte: própria }
$$

A partir do valor de referência foi incrementada a luminância de acordo à inclinação 
da curva na figura 45, em intervalos de $0.5 \mathrm{~mm}$ numa faixa de 2 a $5 \mathrm{~mm}$ de diâmetro. $\mathrm{O}$ delta de incremento lumínico aplicado à imagem foi estimado calculando a inclinação da curva entre dois pontos a cada intervalo e normalizando esses valores. Adicionalmente, da simulação retina.m sob parâmetros realistas sem EV obteve-se a imagem 62-(a) (ver a figura no capítulo de Resultados) a qual foi utilizada como imagem de entrada no algoritmo pupila.m e tomada como imagem de referência.

\subsection{Modelo de detecção de bordas baseado no meca- nismo de Oponência de Cor - oponencia_cor.m}

A informação de cor é processada no sistema visual na forma de comparação/oponência de informação. As principais interações de oponência na retina ocorrem entre cones-L e cones-M, e entre os cones-S e uma combinação dos cones-L e M. Acredita-se que o sinal L/M seja codificado pelas células bipolares Midget e pelas células horizontais [53]. As vias horizontais e amácrinas dentro da retina permitem comparações espaciais dos sinais dos cones [189].

As células ganglionares e/ou as células do LGN possuem campos receptivos de oponência simples (centro-periferia) e as células no córtex primário V1 possuem oponência dupla, onde os seus campos receptivos possuem oponência cromática e espacial [53]. Alguns neurônios em V1 são sensíveis à orientação de padrões cromáticos e acromáticos e são chamados neurônios duplo-oponente de orientação [98]; consideram-se cruciais na detecção de bordas de cenas naturais a cor.

Desta forma, seria plausível que falhas na regulação no processamento de baixo-nível na retina, por exemplo nas células horizontais e /ou bipolares, interferissem nos pesos dos cones-L/M influenciando a informação que passa pelas células ganglionares, que posteriormente será processada pelas células de oponência dupla do córtex visual V1.

Alguns autores têm proposto vários modelos computacionais para descrever o mecanismo de Oponência de Cor, nos quais são simulados os campos receptivos dos neurônios de oponência simples e de oponência dupla com orientação seletiva. No modelo proposto por Yang et al. [236] o campo receptivo de oponência dupla foi modelado como dois campos receptivos com sinal oposto colocados lado a lado (figura 48). A estrutura dos campos receptivos com os pesos dos cones balanceados é mostrada do lado esquerdo da figura 48; este campo receptivo pode responder adequadamente às bordas definidas pela 
cor [236]. No lado direito da figura, a estrutura de campos receptivos com pesos dos cones desequilibrados podem responder às grades acromáticas e iso-luminantes [236].

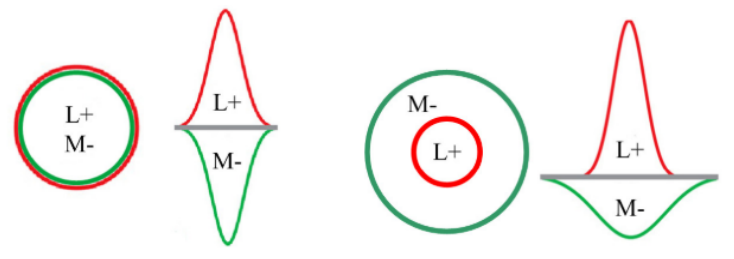

a) Oponência Simples
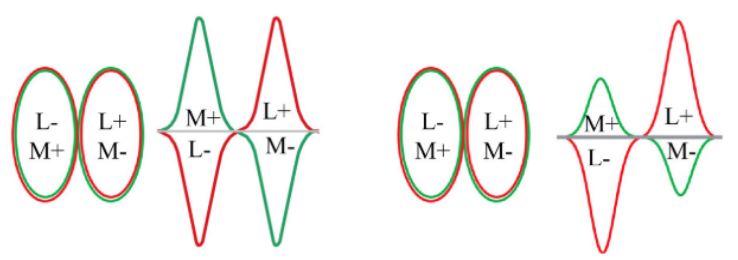

b) Oponência Dupla

Figura 48: Campos receptivos da células que realizam oponência de cor.

Fonte: Adaptado de Yang (2015) [236]

O modelo de Yang [236] reproduz o comportamento destes campos receptivos e permite alterar os pesos dos cones para realizar a oponência de cor, o que possibilita ilustrar as modificações que poderiam acontecer na deteç̧ão de bordas da imagem. Este modelo exibe um bom desempenho na captura simultânea das bordas cromáticas e acromáticas.

O modelo inclui 3 camadas (ver figura 49). Na primeira camada (Camada Cone) são usados filtros gaussianos que simulam os campos receptivos dos cones para obter informações locais sobre as componentes individuais de cor (vermelho, verde, azul e amarelo) da imagem de entrada. Na camada Ganglionar/LGN, as respostas dos neurônios de oponência simples são transformados em dois pares de componentes de cor: R-G / G-R e B-Y / Y-B, formando 4 canais oponentes. Na última camada (Camada Córtex), múltiplos filtros de seleção de orientação de oponência dupla são usados para extrair os contornos. O máximo é calculado para combinar os contornos obtidos nos canais oponentes [236]. O papel principal das duas primeiras camadas é a percepção de cor da região, enquanto a terceira camada foca na obtenção dos contornos cromáticos e acromáticos.O equacionamento utilizado para gerar a resposta de cada camada do modelo é apresentada a seguir.

Camada Cones Nesta camada, a imagem de entrada é separada em quatro canais: componentes vermelho $(R)$, verde $(G)$, azul $(B)$ e amarelo $(Y)$, onde $Y=(R+G) / 2$. A fim de obter informações sobre a cor local, filtros gaussianos são usados para simular o campo receptivo dos cones na retina. O desvio padrão controla o tamanho do campo 


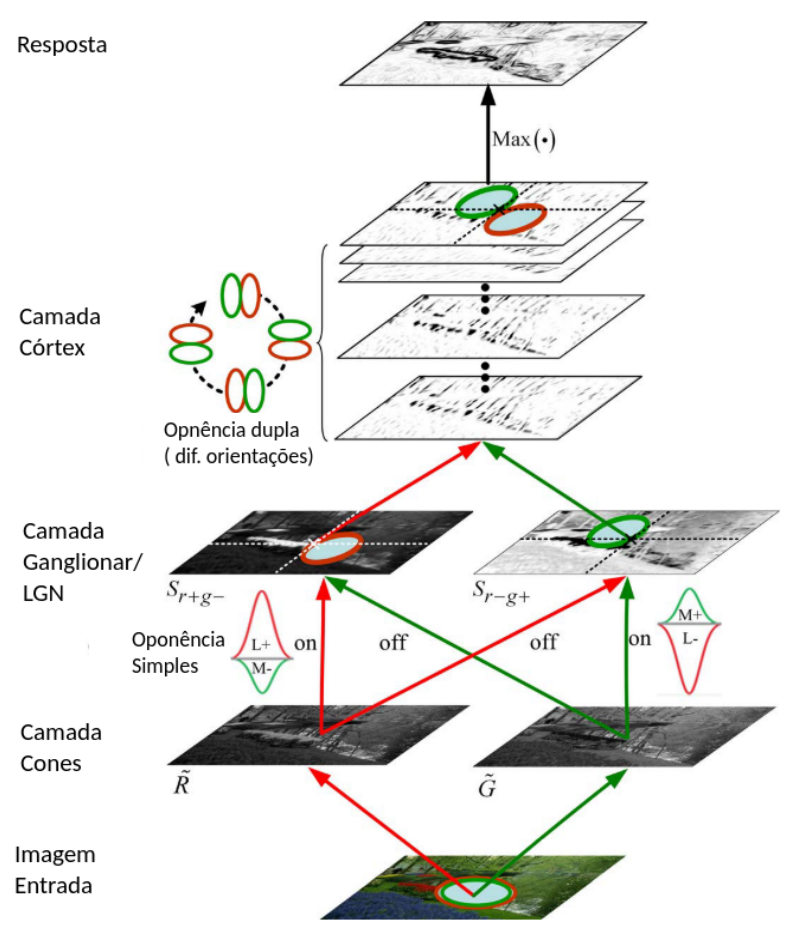

Figura 49: Camadas do modelo de Oponência de cor de Yang.

Fonte: Adaptado de Yang (2015) [236]

receptivo. A saída das quatro componentes de cor são denotadas por $\tilde{R}, \tilde{G}, \tilde{B}$ e $\tilde{Y}$.

Camada Ganglionar/LGN As células nesta camada possuem campos receptivos de oponência simples e apresentam propriedades espaciais passa-baixas. Elas recebem as saídas dos cones, e suas respostas podem ser descritas como:

$$
\begin{gathered}
S_{r g}(x, y)=w_{1} \bullet \tilde{R}(x, y, \sigma)+w_{2} \bullet \tilde{G}(x, y, \sigma) \\
\text { onde, } \quad\left\{\begin{array}{l}
w_{1} w_{2} \leq 0 \\
\left|w_{1}\right|,\left|w_{2}\right| \in[0,1]
\end{array}\right.
\end{gathered}
$$

onde $w 1$ e w2 são os pesos dos cones (regulados pelas células horizontais e bipolares) na conexão com as células ganglionares. Com $w 1>0$ e $w 2<0$ são obtidas as respostas das células R-ON/G-OFF e com $w 1<0$ e $w 2>0$ são obtidas as respostas das células ROFF/G-ON. w1 e w2 sempre têm signo oposto.

As células de oponência simples na camada Ganglionar/LGN são importantes para 
separar informações de cor e acromáticas (eq. 5.7). Quando os pesos dos cones que entram na camada de células Ganglionares/LGN estão equilibrados, ou seja, $|w 1|=\mid$ w2 $\mid$ , as células Ganglionares/LGN não conseguem distinguir a informação acromática, porque neste caso a informação acromática estaria fornecendo os mesmos valores nas componentes de diferentes canais. Em contraste, quando os pesos dos cones estão desequilibrados, ou seja, $|w 1| \neq \mid$ w2 $\mid$, o modelo possui a habilidade de detectar mudanças na luminância.

Camada Córtex Na camada do córtex (área V1), os campos receptivos da maioria dos neurônios sensíveis à cor e à luminância de cor são opostos cromática e espacialmente. Considera-se que as células com oponência dupla e sensibilidade à orientação desempenham um papel importante na detecção de bordas. Os campos receptivos destas células de orientação dupla e sensibilidade à orientação podem ser simulados por meio das seguintes equações:

$$
\begin{gathered}
V(x, y ; \theta, \sigma)=\frac{\partial f(x, y ; \theta, \sigma)}{\partial(\tilde{x})} \\
f(x, y ; \theta, \sigma)=\frac{1}{\sqrt{2 \pi(k \sigma)^{2}}} \exp \left\{\frac{-\tilde{x}^{2}+\gamma^{2} \tilde{y}^{2}}{2(k \sigma)^{2}}\right\} \\
{\left[\begin{array}{c}
\tilde{x} \\
\tilde{y}
\end{array}\right]=\left[\begin{array}{c}
x \cos \theta+y \sin \theta \\
-x \sin \theta+y \cos \theta
\end{array}\right]}
\end{gathered}
$$

Onde $\theta \in[0,2 \pi)$ é a orientação de determinada célula. $\gamma$ é controla a elipticidade do campo receptivo e é colocado igual a 0.5 devido a características fisiológicas [236]. $k$ e $\sigma$ possuem a mesma escala do filtro gaussiano da camada Ganglionar/LGN. $k \sigma$ determina o tamanho dos campos receptivos dos neurônios V1. A resposta das células de oponência dupla é calculada convoluindo a resposta das células de oponência simples (eq. 5.7) com a dos campos receptivos (ver eq. 5.12).

$$
\begin{array}{r}
D_{r g}\left(x, y ; \theta_{i}, \sigma\right)=S_{r g}(x, y) * R F_{1}\left(x, y ; \theta_{i}, \sigma\right) \\
-S_{r g}(x, y) * R F_{2}\left(x, y ; \theta_{i}, \sigma\right) \\
R F_{1}\left(x, y ; \theta_{i}, \sigma\right)=\mathbb{H}\left(V\left(x, y ; \theta_{i}, \sigma\right)\right)
\end{array}
$$




$$
\begin{gathered}
R F_{2}\left(x, y ; \theta_{i}, \sigma\right)=\mathbb{H}\left(-V\left(x, y ; \theta_{i}, \sigma\right)\right) \\
\mathbb{H}(s)= \begin{cases}s, & s>0 \\
0, & s \leq 0\end{cases}
\end{gathered}
$$

Na equação 5.12 a resposta foi calculada para o canal RG. $\theta_{i}$ foi calculada como mostrado na eq 5.16 com $N_{\theta}$ sendo o número total de orientações.

$$
\theta_{i}=\frac{2(i-1) \pi}{N_{\theta}}, \quad i=1,2,3 \ldots N_{\theta}
$$

No modelo de Yang é calculado o máximo para combinar os contornos através de todos os canais oponentes. No entanto, neste trabalho, foi realizada a soma dos contornos de todos os canais. Assim, saída de cada canal é normalizada linearmente e a resposta final é obtida somando a resposta de cada canal de acordo com

$$
r(x, y)=\operatorname{sum}\left\{D_{c_{i}}(x, y) \mid c_{i} \in\{r g, g r, b y, y b\}\right\}
$$

O fluxograma resumindo os passos do modelo é mostrado na figura 50

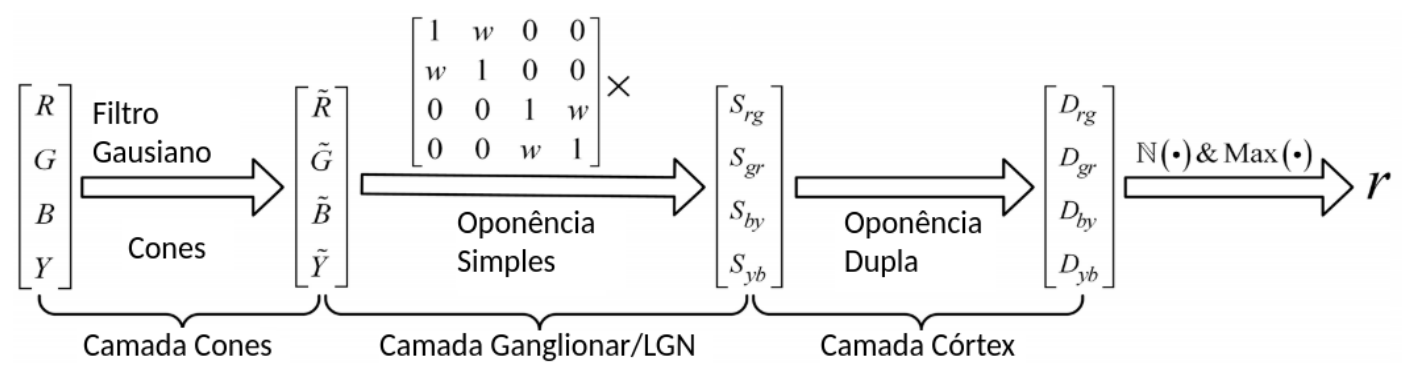

Figura 50: O fluxograma resumindo os passos do modelo de Yang.

Fonte: Adaptado de Yang (2015) [236]

\subsubsection{Imagens de entrada}

A imagem 46 é foi utilizada como imagem de entrada no algoritmo para ilustrar como se veria alterada a capacidade de distinguir objetos sobrepostos, o que estaria relacionado à percepção de profundidade. 
A manipulação dos parâmetros $w_{1}$ e $w_{2}$ permite observar a detecção de bordas com modificações no canal de luminância. Os parâmetros utilizados no algoritmo estão enunciados na tabela 3 . O mesmo desvio padrão foi utilizado para cada componente de cor.

\begin{tabular}{|l|c|}
\hline Parâmetro & Valor \\
\hline$\sigma$ & 2.6 \\
$k$ & 2 \\
$\gamma$ & 0.5 \\
$N_{\theta}$ & 16 \\
$w 1$ & 1 \\
$w 2$ equilibrado & -1 \\
w2 desequilibrado & -0.6 \\
\hline
\end{tabular}

Tabela 3: Parâmetros utilizados na implementação do modelo de Yang

Os sintomas do EV são normalmente percebidos durante a leitura. Portanto, é interessante conhecer como seria processada a imagem de um texto sob modificações nas informações fornecidas ao canal de luminância. Para isto, a imagem 51 foi usada como imagem de entrada no algoritmo.

Sensitivity Syndrome, and Visual Stress) is a perceptual processing disorder. It is not an optical problem. It is a problem with the brains ability to process visual information. This problems tends to run in families and is not currently identified by other standardized educational or medical test.

Figura 51: Imagem de entrada no algoritmo - Texto

Fonte: própria

\subsection{Modelo do fenômeno de Persistência Visual - persistencia_visual.m}

Solan et al. sugeriu que qualquer alteração na ordem normal do processamento dos caminhos Parvocelular e magnocelular, ou nos tempos relativos das determinadas contribuições de cada caminho, podem resultar numa deficiência visual [188].

Na leitura, o caminho Parvocelular é ativado para obter o detalhes do texto, o que faz que este sistema possua uma resposta mais longa e que permanece até o final do estímulo. A estimulação do sistema magnocelular deve realizar, a cada sacada, a inibição ou supressão do estímulo fixado no sistema Parvocelular. Quando o acoplamento nos tempos deste dois sistemas está sincronizado, evita-se que a informação visual adquirida numa 
fixação interfira com a informação visual adquirida na próxima fixação; efeito conhecido como persistência visual. A figura 52 representa a sequência de adquisição de estímulos visuais hipotética dos caminhos transiente (magnocelular) e contínuo (Parvocelular) quando funcionando adequadamente.

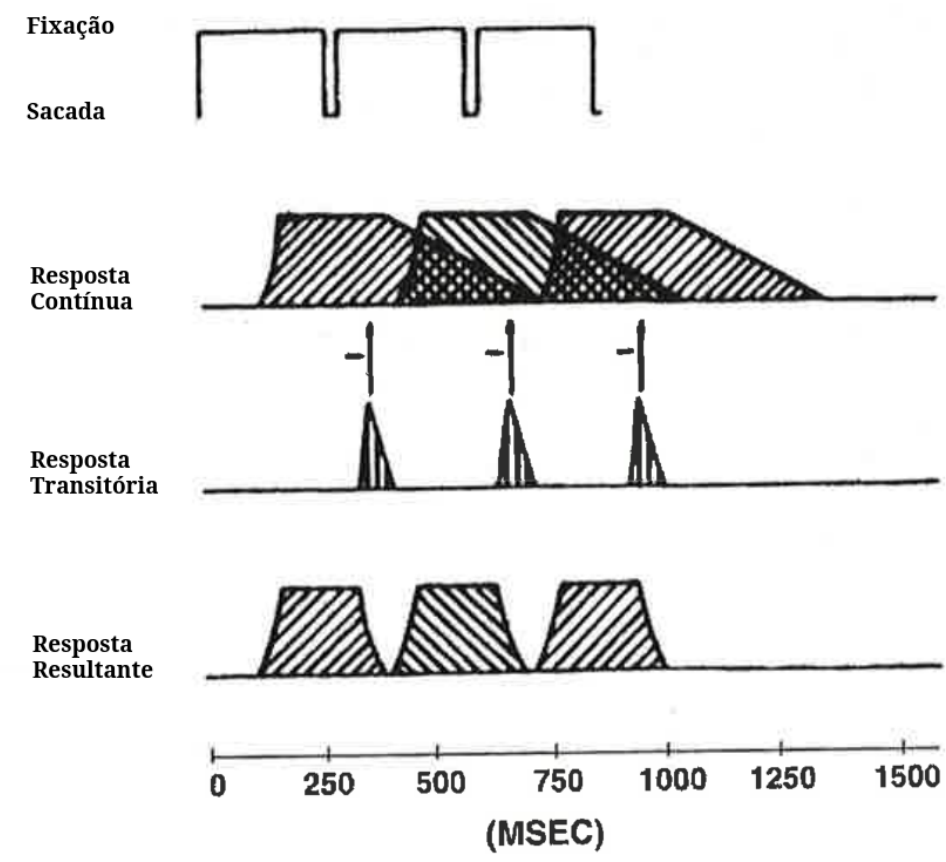

Figura 52: Sequência de atuação hipotética do sistema transiente e contínuo. Adaptado de [188]

Fonte: Adaptado de Solan (1998) [188]

A alteração na fase de funcionamento dos sistemas Parvocelular e Magnocelular, usualmente é atribuído a um atraso na ativação do sistema Magnocelular. Sugere-se que tal atraso tem um efeito relevante na eficiência do sistema óculo-motor na leitura, pois quando estes dois sistemas estão dessincronizados a supressão sacádica pode acontecer depois que as imagens de duas fixações já foram superpostas ou simplesmente não acontecer. Assim, o sistema visual teria que agir gerando mais regressões e fixações mais longas para conseguir descifrar os estímulos que estão sendo percebidos inadequadamente.

As baixas frequências espaciais da imagem adquiridas pelo sistema Magnocelular são utilizadas para guiar os movimentos oculares ao ponto central da próxima fixação. Um atraso nesta informação poderia alterar a localização ótima do próximo ponto de fixação, gerando uma penalidade na sua duração. A figura 53 ilustra a hipótese da percepção do estímulo visual se não acontecesse a supressão sacádica causada pelo atraso na resposta do sistema Magnocelular.

Uma simulação computacional foi desenvolvida para representar a sequência de passos 


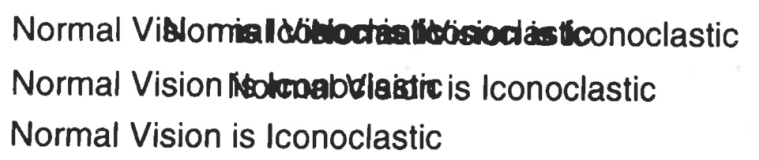

(Três Fixações)

(Duas Fixações)

(Uma Fixação)

Figura 53: Imagem hipotética da imagem vista em várias fixações quando a supressão sacádica é inibida. Fonte: Adaptado de Solan (1998) [188]

que executam o sistema Parvo e Magnocelular na adquisição da informação visual na leitura. O atraso no sistema Magnocelular foi simulado mediante a inibição do estímulo de supressão sacádica.

\subsubsection{Descrição do algoritmo que simula a Persistência Visual}

A entrada para a simulação é a imagem de um texto. A parte do algoritmo que simula o sistema Magnocelular vai selecionando a cada iteração 8 caracteres de texto por linha, que seria o span de reconhecimento de uma criança que acabou de aprender a ler [117]. A parte do algoritmo que simula o Parvocelular seleciona uma letra à direita e uma à esquerda a partir da terceira letra selecionada pelo Magnocelular; esta porção de texto seria o foco da fixação. Assim, a entrada do Magnocelular indica ao Parvocelular onde deve fixar o foco e adquirir os detalhes da imagem. O algoritmo toma todos os caracteres do texto por igual, contando com os espaços em branco e palavras frequentes; ou seja, não faz distinção entre complexidade o frequência das palavras.

As faixas de texto selecionadas pelo sistema Magnocelular e Parvocelular são fusionadas. Cada estímulo do Magnocelular irá ser chamado de Where_n e do Parvocelular de What_n. Assim, cada estímulo visual em sequência (fixação a cada sacada) seria uma imagem da fusão Where_n+What_n, e uma linha de texto estaria representada pela equação 5.18 .

$$
I_{l}=\left(\text { Where }_{1}+\text { What }_{1}\right)+\left(\text { Where }_{2}+\text { What }_{2}\right)+\ldots+\left(\text { Where }_{n}+\text { What }_{n}\right)
$$

Onde I_l é a sequência de imagens registradas durante a leitura de uma linha de texto, Where_n é o estímulo captado pelo sistema Magnocelular e What_n pelo sistema Parvocelular.

$\mathrm{Na}$ hipótese do correto funcionamento (sincronismo) destes dois sistemas na leitura, 
nesta sequência, cada Where_n é somado com seu respectivo What_n sem considerar o What_n-1 (anterior) que é eliminado pelo estímulo de supressão sacádica.

Desta forma, quando se atrasa ou se elimina o estímulo de supressão sacádica a imagem que chegará no córtex para ser decodificada estará contaminada pelo estímulo da fixação anterior (Where_n + What_n + What_n-1). Isto está representado na equação 5.19.

$I_{l-s c}=\left(\right.$ Where $_{1}+$ What $\left._{1}\right)+\left(\right.$ Where $_{2}+$ What $_{2}+$ What $\left._{1}\right)+\ldots+\left(\right.$ Where $_{n}+$ What $_{n}+$ What $\left._{n-1}\right)$

Onde I $l-s c$ é a sequência de imagens registradas durante a leitura de uma linha de texto quando não acontece a supressão sacádica, Where_n é o estímulo captado pelo sistema Magnocelular, What_n o captado pelo sistema Parvocelular e What_n-1 o estímulo anterior captado pelo sistema Parvocelular.

\subsubsection{Imagem de entrada}

A imagem 54 foi utilizada como entrada no algoritmo que simula a Persistência Visual para representar a distorção que ocorreria se os sistemas visuais estivessem descoordenados.

Sensitivity Syndrome, and Visual Stress) is a perceptual processing disorder. It is not an optical problem. It is a problem with the brains ability to process visual information. This problems tends to run in families and is not currently identified by other standardized educational or medical test.

Figura 54: Imagem entrada no programa que simula a Persistência visual Fonte: própria

\subsection{Modelo do Controle Ocular - ctrl_ocular.m}

A sacada é um movimento ocular voluntário no qual os olhos se movem rapidamente de um lado pra outro. Na leitura, os principais movimentos oculares são as sacadas horizontais para adquirir a informação de uma linha de texto e verticais para mudar de linha [232]. 
Nos modelos de controle dos movimentos oculares, o sistema de controle da sacada deve agir como um servo controlador da posição para mudar e manter o alvo no centro da retina com o mínimo de tempo. Vários tipos de modelos são utilizados para fornecer o controle dos movimentos oculares, por exemplo, de robôs [244]. Robinson [171] formulou um modelo de pontos amostrados para a sacada o qual é uma modificação do modelo mais antigo de Young e Stark [237]. No modelo, se considera o controle cerebral adicionando um circuito pré-motor, que consiste no Fascículo Medial Longitudinal (MLF) e num Integrador Neural (NI). O esquema do modelo formulado por Robinson é apresentado na figura 55.

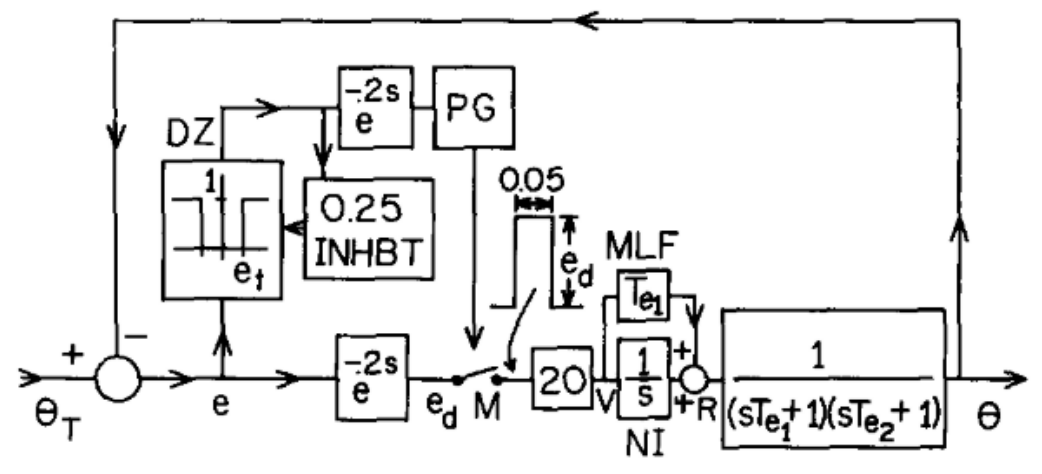

Figura 55: Planta do modelo de controle sacádico formulado por Robinson Fonte: Robinson (1973) [171]

O circuito contém a zona morta (Dead Zone - DZ) e um dispositivo para inibir o circuito de cronometragem (INHBT). Quando o erro $e$ excede certo limite $e_{t}$, o gerador de pulsos (Pulse Generator - PG) é acionado, o que faz com que uma amostra seja capturada ao mesmo tempo que o elemento INHBT bloqueia a zona morta por 0,25 segundos. O modelo descreve o sacada usando loops de controle discretos em vez de contínuos. Na parte do circuito pré-motor, o MLF forma a rede principal para compensar o atraso da planta, enquanto o NI produz o sinal de posição. Então, a soma da via MLF e NI pode ser considerada como a entrada da mecânica do globo ocular. A função de transferência no bloco seguinte indica a posição do olho na próxima sacada. O circuito pré-motor é consistente com a neurofisiologia pois o cérebro processa os dados em paralelo [171].

A função de transferência foi obtida a partir da relação entre o movimento ocular e a atividade motora do nervo ocular em gatos. Este resultado foi confirmado em motoneurônios de macaco. Nesta, as constantes $T_{e 1}$ e $T_{e 2}$ são constantes de tempo relacionadas às velocidade de resposta dos motoneurônios. $T_{e 2}$ é aproximadamente $7 \mathrm{mseg}$, o que poderia ser considerado como desprezível; enquanto $T_{e 1}$ em humanos foi estabelecido entre 100 e $200 \mathrm{mseg}[171]$. 
No trabalho realizado por Robinson, o movimento sacádico foi ideado para o caso em que o indivíduo estivesse seguindo um alvo em movimento, onde $\theta_{T}$ seria a posição do alvo e $\theta$ seria a posição dos olhos. No entanto, é possível extrapolar este modelo para as sacadas na leitura; neste caso, $\theta_{T}$ seria a posição da próxima fixação e $\theta$ continuaria sendo a posição dos olhos.

Como resposta do modelo ao pulso, apenas no final de uma sacada, o pulso leva o olho para uma nova posição e o trabalho do integrador é mantê-lo lá. Se a razão entre as transmissões neurais através de NI e MLF não for $T_{e 1}$ o olho irá se desviar e então se aproximará exponencialmente de uma nova posição estacionária [171]. Os resultados da alteração do ganho de MLF são mostrados na figura 56.

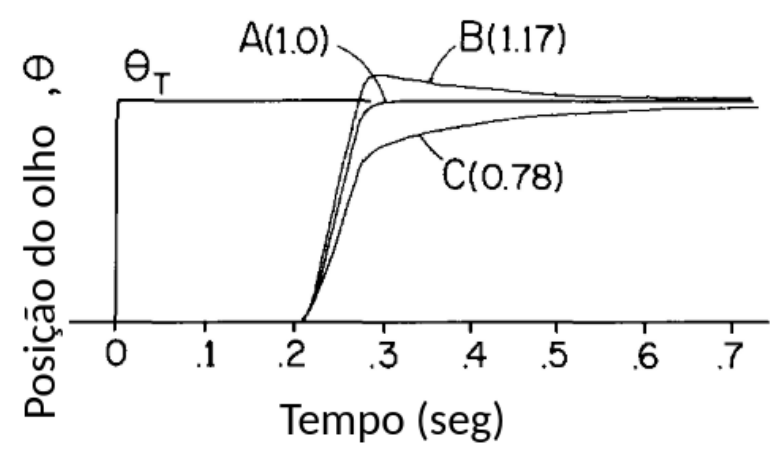

Figura 56: Tipos de respostas para a posição alvo $\theta_{T}$. Na curva A, o ganho do bloco MLF é normal, na curva B é $17 \%$ maior e na curva $\mathrm{C}$ é $22 \%$ menor.

Fonte: Adaptado de Robinson(1973) [171]

O modelo prevê corretamente os resultados de etapas simples e de feedback visual que causam o movimento sacádico na condição de laço aberto e oscilações para um feedback negativo. Desta forma, com base no modelo de Robinson, foi desenvolvido o algoritmo ctrl_ocular.m que simula os movimentos sacádicos na leitura.

No algoritmo, a mudança do parâmetro do MLF permite simular a disfunção no controle ocular do movimento sacádico, ao modificar o ponto de fixação que se desloca de acordo às curvas aparentadas na figura 56. Assim, se a sacada segue um comportamento como o mostrado na curva B, e uma vez que a adquisição de informação na fixação começaria quando a curva A chega no ponto $\theta_{T}$, a posição do olho neste momento estaria alguns espaços além da posição ótima. Enquanto o olho chega na posição correta de fixação $\left(\theta_{T}\right)$ estará sendo adquirida informação visual durante a movimentação ocular, gerando a percepção de movimento, embaçamento e/ou sobreposição das letras. 


\subsubsection{Imagem de entrada}

A imagem de entrada no algoritmo é apresentada na figura 57. No algoritmo foi simulada também a resolução espacial da imagem, de acordo à disposição dos fotorreceptores e células ganglionares (ver explicação na seção Fisiologia). Portanto, a imagem fica mais nítida no centro (foco) e vai ficando mais embaçada nas regiões periféricas (ver figura 58).

Sensitivity Syndrome, and Visual Stress) is a perceptual processing disorder. It is not an optical problem. It is a problem with the brains ability to process visual information. This problems tends to run in families and is not currently identified by other standardized educational or medical test.

Figura 57: Imagem de entrada no algoritmo ctrl_ocular.m

Fonte: Própria

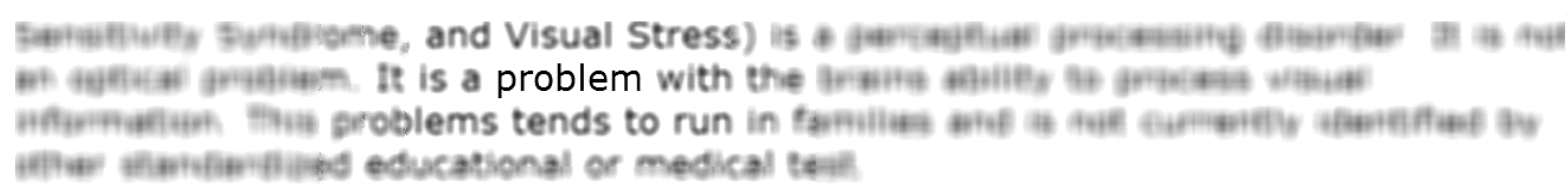

Figura 58: Imagem de entrada vista com a resolução espacial do Sistema visual

Fonte: Própria

Para realizar cada sacada e posicionar o olho no lugar alvo, o algoritmo considera o tamanho da palavra (palavras curtas como artigos, por exemplo, são omitidas) e a partir disso planeja o próximo ponto de fixação. Conhecendo a posição correta do ponto de fixação faz uma comparação com a posição dada pelo modelo computacional (máximo da curva); esta diferença será a defasagem na localização do próximo ponto de fixação. A defasagem pode acontecer horizontalmente, isto é, a sacada desloca o olho no mesmo eixo da leitura, ou pode ter componentes de defasagem tanto horizontais como verticais simultaneamente (defasagem diagonal), ou seja, o olhar se posicionaria adiante e, acima ou embaixo, da posição alvo.

O algoritmo cria um vídeo mostrando a informação que é adquirida desde que o olho se posiciona no ponto estabelecido pela saída do modelo até que chega no ponto ótimo de fixação, nas duas situações. 


\section{RESULTADOS}

Os resultados das simulações computacionais serão apresentados na ordem em que foram descritos os modelos matemáticos e seus respectivos modelos computacionais no capítulo Metodologia 5.

\subsection{Modelo da Retina - retina.m}

A imagem na figura 43 foi processada sob os parâmetros realistas (ver tabela 2) mudando o ganho do filtro $F_{h}$ que simula uma retina com e sem EV, isto é mostrado na figura 59 (a) e (b), respectivamente. Como pode ser visto, na imagem 59-(a), a luminosidade da imagem diminuiu e as bordas das letras mantiveram-se, fazendo a imagem confortável de observar; isto, pela diminuição do contraste branco-preto e a preservação do formato das letras. Por outro lado, na figura 59-(b) devido ao aumento de brilho do fundo, algumas bordas das letras perderam-se, fazendo o texto ininteligível.

Diminuindo a frequência espacial na imagem do texto (figura 44) e processando-a no algoritmo retina.m são obtidos os resultados apresentados na figura 60. As imagens 60-(a) e (b) simulam uma visão sem e com EV, respectivamente.

Da figura 60-(a) pode ser visto que a compressão da luminância se manteve e as bordas das letras continuam nítidas; não houve mudanças na observabilidade quando comparada com a imagem de texto em frequência média (figura 59-(a)). Por outro lado, observando a figura 60-(b) e comparando-a com a figura 59-(b), embora nos dois casos o brilho do fundo aumentou, na segunda imagem as letras continuam sendo compreensíveis. 


\begin{abstract}
visual perception now termed "Meares-Irlen syndrome. Anecdotal reports of the success of her tinted lenses were met th skepticism justified by the lack of scientific evidence. Reitly, however, Wilkins and coworkers ${ }^{4,5}$ developed an alternae method of prescribing colored glasses. 'The method has the vantage that colors are searched systemarically and comprehenely, and an optimal tint is provided with ninimal absorbance of ht. Central to the merhod is a simple optical device (Intuitive Jorimeter, Cerium Visual 'Technologies, 'Tenterden, Kent, UK) It optimizes the tint while the eyes are color-adapted. The hue d saturation are alternately adjusted so as to reduce perceptual tortions to a minimum with colored light of an oprimum chroticity. 'I'inted trial lenses can be selected that match the chrouriciry of the oprimal colored light and provide a spectral march that obtained when the lenses are worn under conventional IE type F3) fluorescent lighting. In a double-masked crial, pants reported fewer episodes of headaches and eve strain when
\end{abstract}

(a)

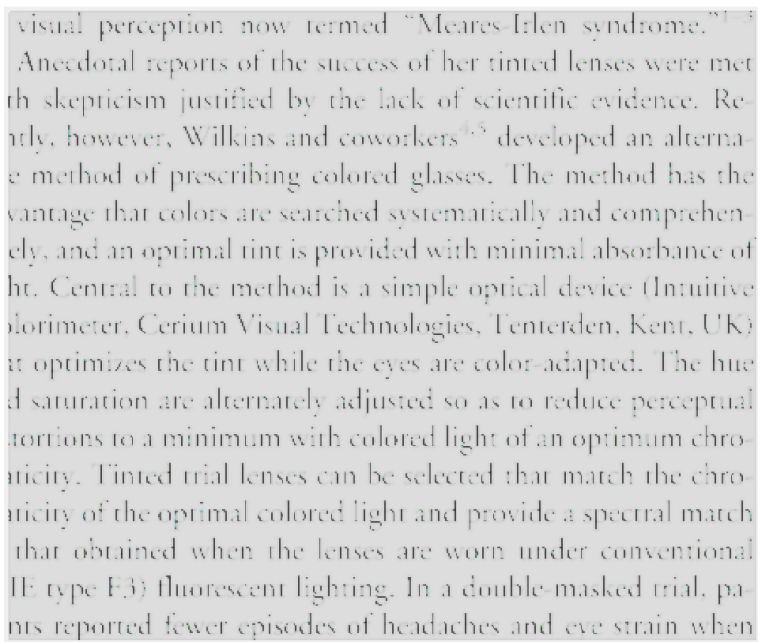

(b)

Figura 59: Saída do canal Parvocelular do algoritmo sob parâmetros realistas, (a) sem EV, e (b) com $\mathrm{EV}$

Fonte: própria

\subsection{Modelo da dilatação da pupila - pupila.m}

A partir do valor de referência foi incrementada a luminância de acordo à inclinação da curva na figura 45, em intervalos de $0.5 \mathrm{~mm}$ numa faixa de 2 a $5 \mathrm{~mm}$ de diâmetro. O delta de incremento lumínico aplicado à imagem foi estimado calculando a inclinação da curva entre dois pontos a cada intervalo e normalizando esses valores. As imagens de saída do algoritmo são apresentadas na figura 61.

Observando o ponto $[\mathrm{x}, \mathrm{y}]:[298,139]$ selecionado em cada uma das imagens da figura 61 pode ser visto que o valor Index, relacionado à intensidade lumínica, aumenta não- 


\begin{abstract}
however, Wilkins and coworkers ${ }^{4,5}$ develope thod of prescribing colored glasses. The me ige that colors are searched systematically anc and an optimal tint is provided with minimal : Jentral to the method is a simple optical dev neter, Cerium Visual Technologies, Tenterde timizes the tint while the eyes are color-adap uration are alternately adjusted so as to redu ons to a minimum with colored light of an of y. Tinted trial lenses can be selected that ma $y$ of the optimal colored light and provide a $s$. obtained when the lenses are worn under
\end{abstract}

(a)

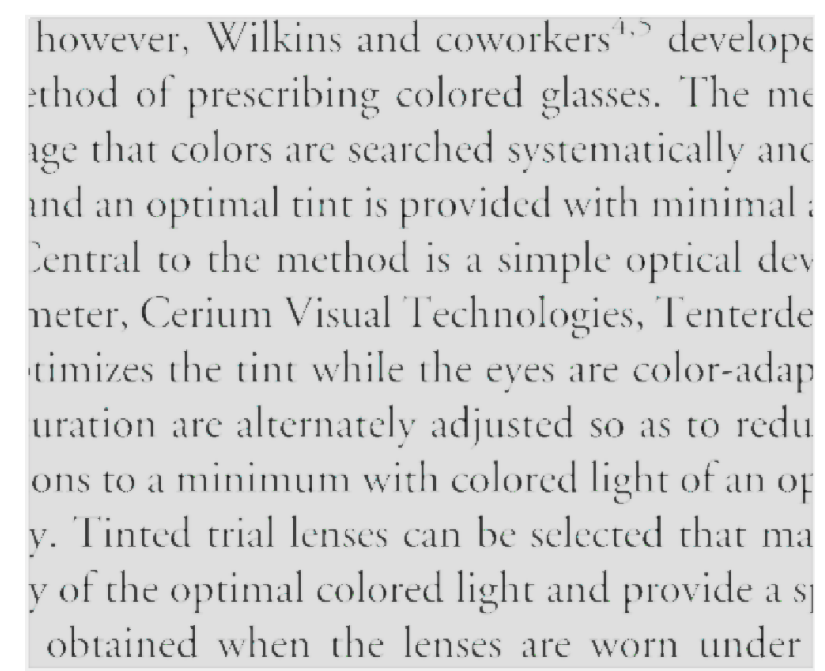

(b)

Figura 60: Saída do canal Parvocelular do algoritmo sob parâmetros realistas, (a) sem EV, e (b) com EV. Imagem com frequência espacial baixa.

Fonte: própria

linearmente na medida que o diâmetro aumenta. Na figura 61-(f) a intensidade lumínica encontra-se notavelmente elevada, até o ponto em que algumas montanhas desapareceram. Nas imagens 61-(b) à (e) o plano de fundo (céu) vai ficando cada vez mais brilhante, e dependendo do observador, isto poderia ou não gerar certo nível de desconforto.

Da simulação retina.m sob parâmetros realistas sem EV obteve-se a imagem 62-(a) a qual foi utilizada como imagem de entrada no algoritmo pupila.m e tomada como imagem de referência. As saídas do algoritmo são mostradas na figura 62. Nesta figura pode-se observar que o brilho do fundo também incrementa com o aumento do diâmetro da pupila. 

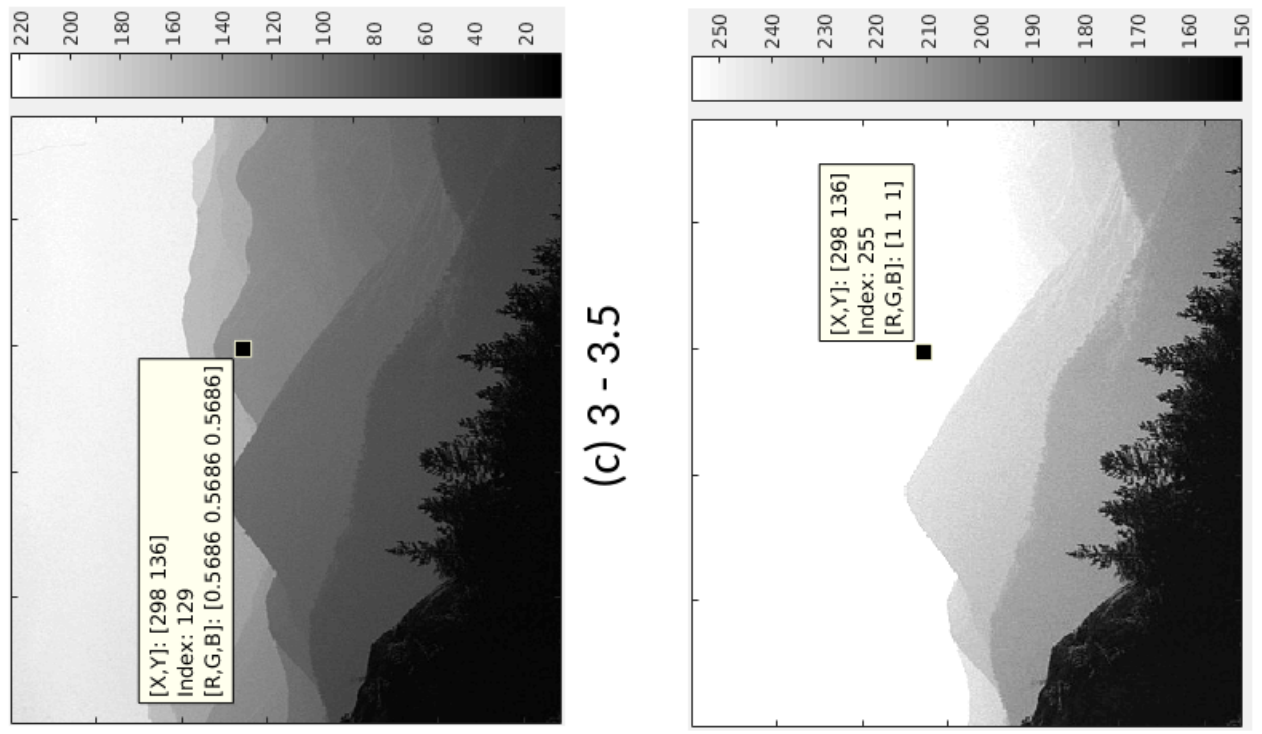

$\frac{+1}{0}$
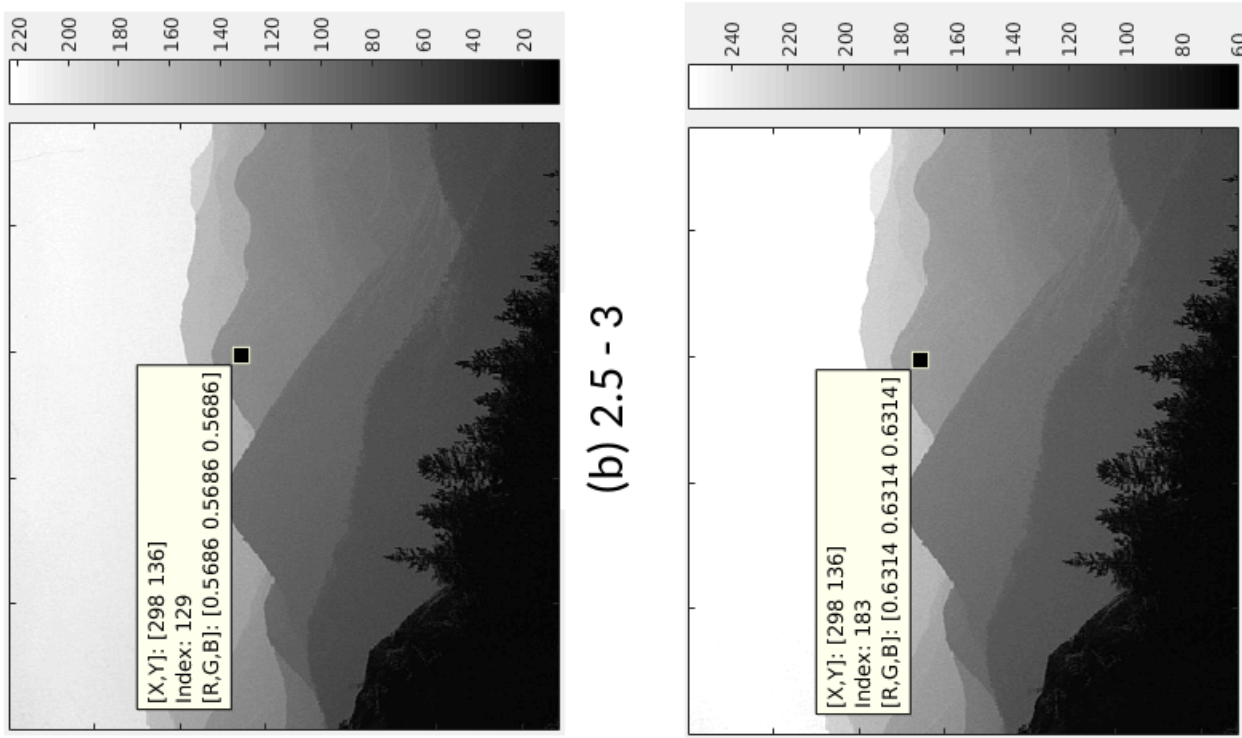

$\stackrel{1}{ \pm}$

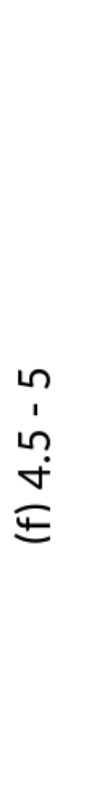

है
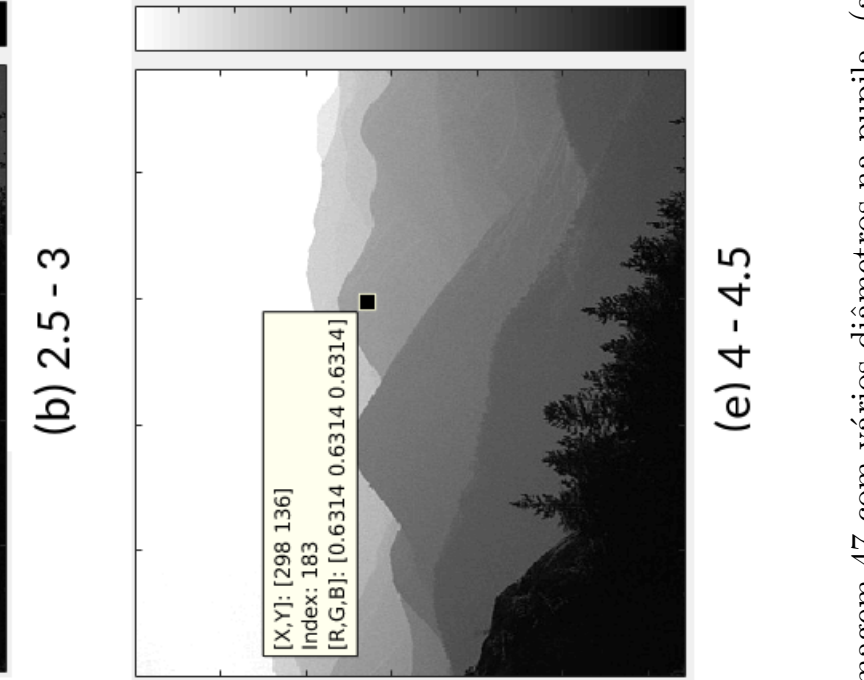

要
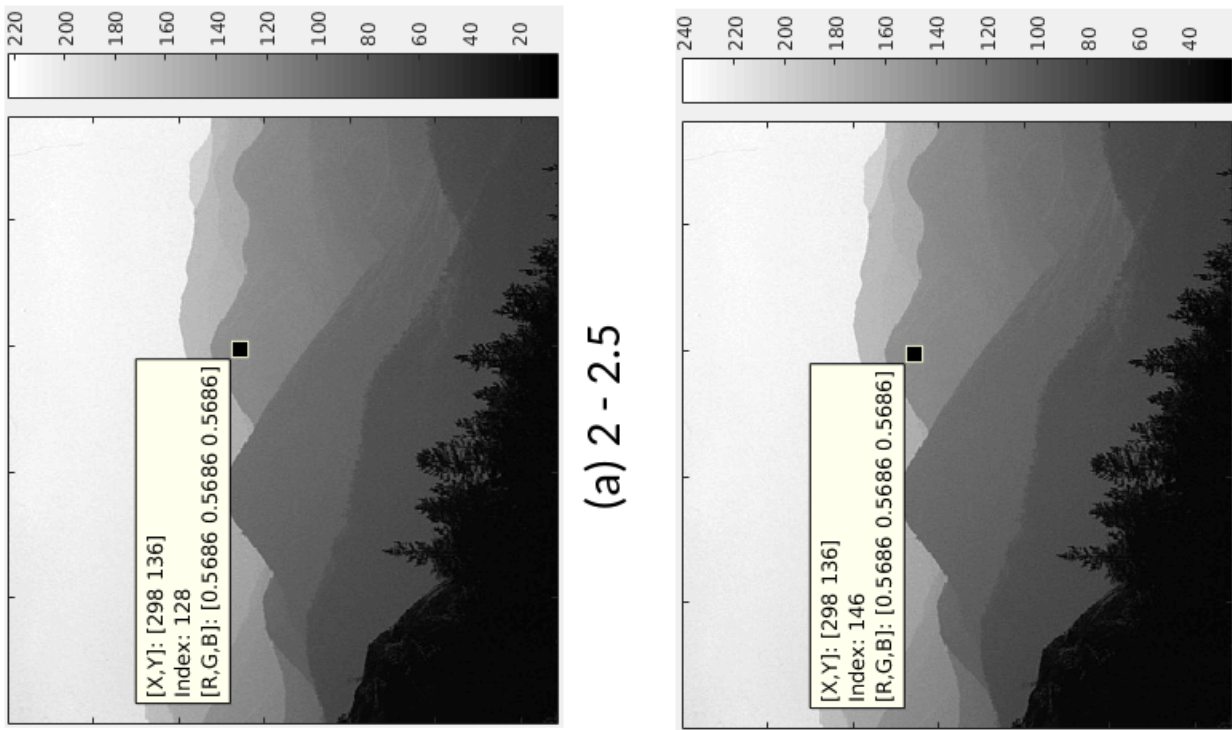

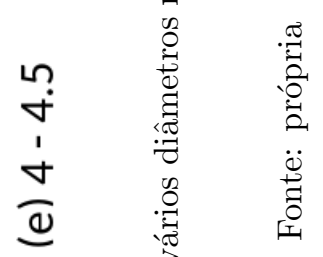
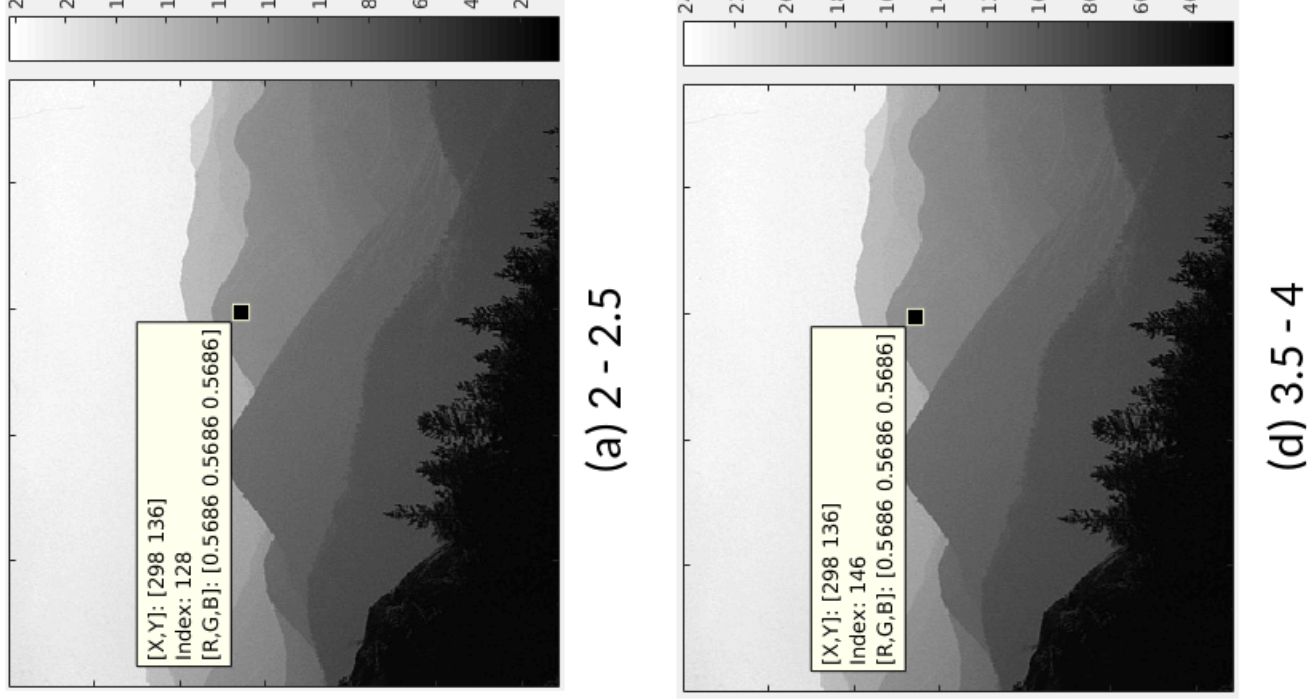
A partir de 4mm de diâmetro na pupila (ver figura 62-(e)) o brilho começa a prejudicar a visibilidade das bordas das letras, até que no diâmetro 4,5 a $5 \mathrm{~mm}$ o reconhecimento das palavras esta quase completamente comprometido (ver figura 62-(f)).

\subsection{Modelo de detecção de bordas baseado do meca- nismo de Oponência de Cor - oponencia_cor.m}

A manipulação dos parâmetros $w_{1}$ e $w_{2}$ permitiu observar a detecção de bordas com modificações no canal de luminância.

A figura 63 mostra as saídas do algoritmo quando: o parâmetro $w_{2}=-0.6$, isto é, com os 4 canais desequilibrados (figura $63-(\mathrm{a})$ ), $w_{2}=-1$, isto é, com os 4 canais equilibrados (figura 63-(b)), $w_{2}=-0.6$ só nos canais RG e GR (figura 63-(c)), e quando as componentes ruidosas da imagem 63-(c) são filtradas (figura 63-(d)).

Na figura 63-(a) a habilidade de distinguir contrastes acromáticos é preservada e os contornos das montanhas são evidenciados sem artefatos que possam sem confundidos com objetos inexistentes. Aproximadamente todas as montanhas da imagem foram detectadas e não se apresentam falsos contornos.

Considerando $w_{2}=-1$ (figura 63-(b)), a habilidade de distinguir contrastes acromáticos foi comprometida e apareceram artefatos podem dificultar o correto reconhecimento das bordas das montanhas, criando a ilusão de falsos contornos. O contorno do horizonte é proeminente; isto poderia desviar a atenção do observador das bordas no plano frontal (que também não são muito fortes) gerando a ilusão de ter menos montanhas. Além disso, as bordas de algumas montanhas desapareceram ou ficaram confusas. Artefatos podem ser confundidos com montanhas aparecendo no fundo.

Para calcular os resultados das figuras 63-(a) e 63(b), os pesos dos cones em todos os canais cromáticos (RG, GR, BY, e YB) foram colocados equilibrados. Isto sugere que a deficiência na regulação dos pesos dos cones acontece num nível geral. No entanto, se a modificação no parâmetro $w_{2}$ acontece só nos canais que comprometem a componente de cor vermelha $(R)$, o resultado seria uma detecção de bordas contaminada pelo sinal ruidoso fornecido pelos canais RG e GR (ver figura 63-(c)). Se o efeito dos filtros espectrais é aplicado no algoritmo, ou seja, se as componentes que estão distorcendo a imagem de saída não são mais considerados, alguns artefatos na imagem gerados por esses canais não 

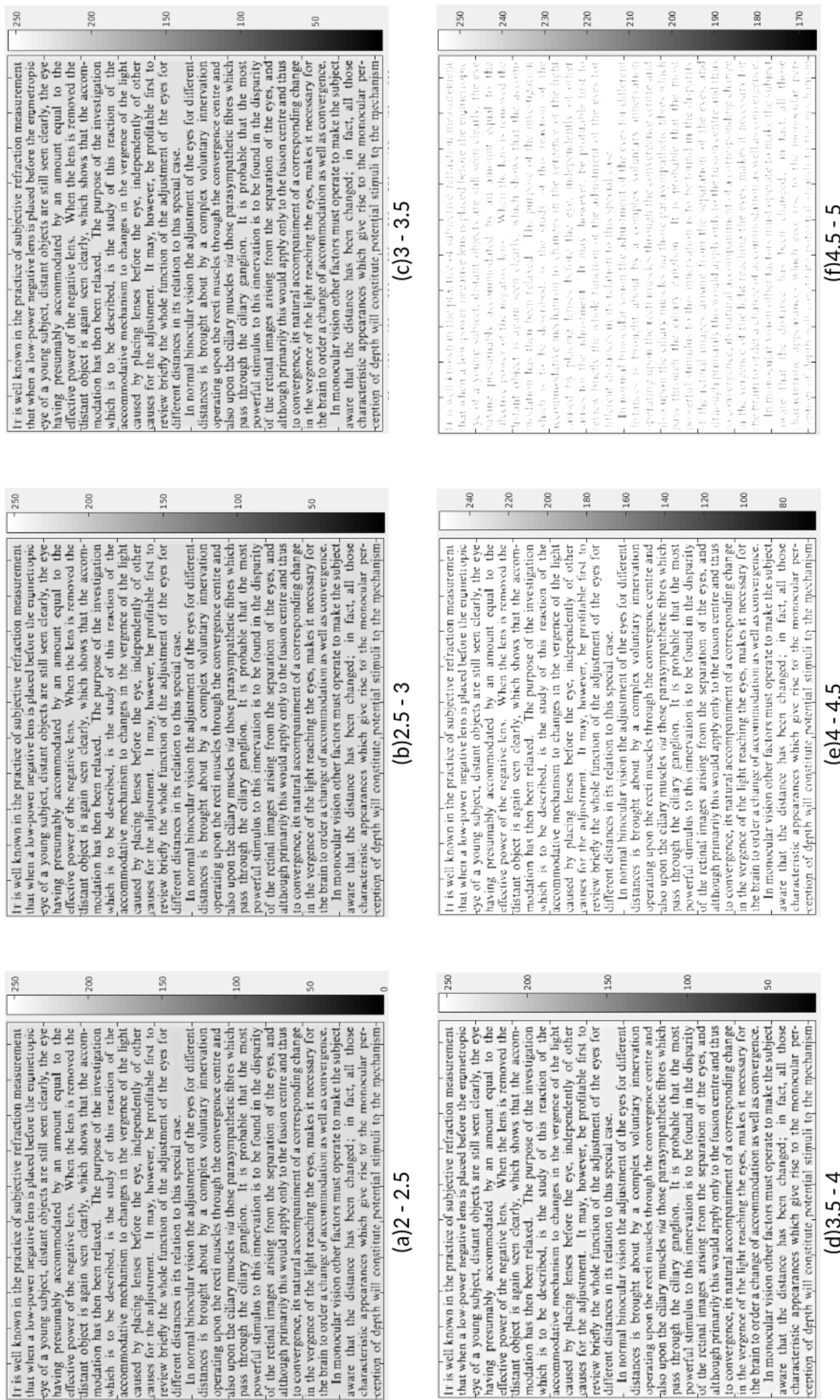


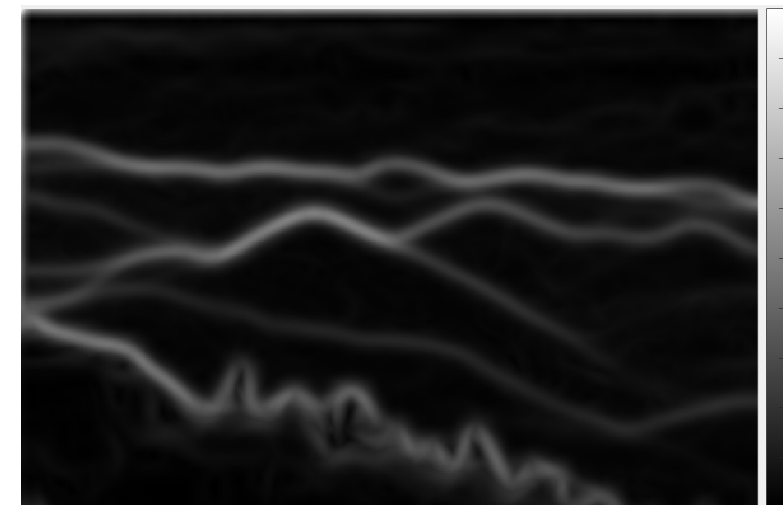

(a)

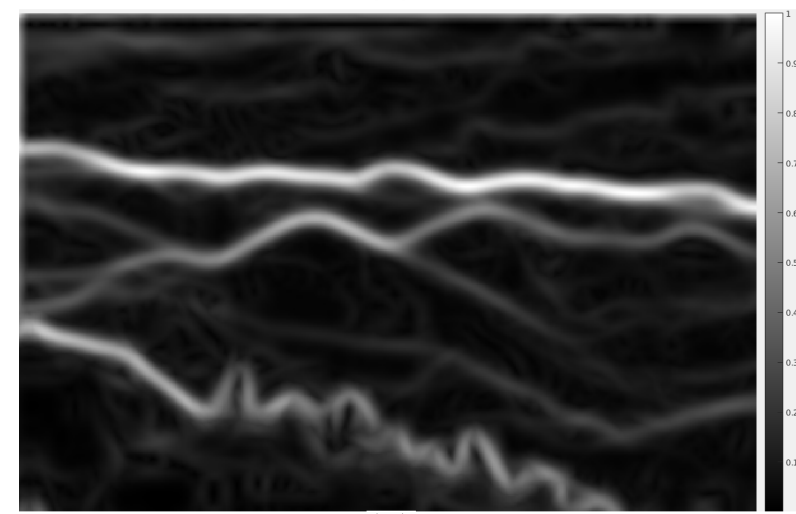

(c)

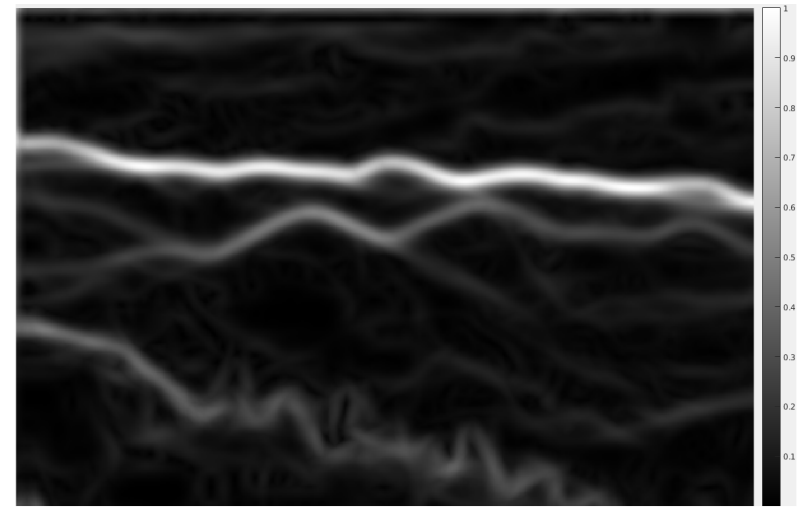

(b)

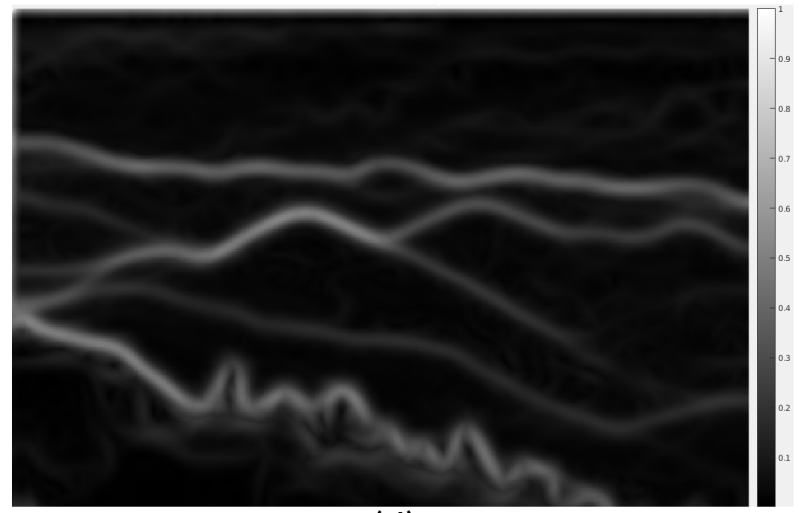

(d)

Figura 63: Imagens de saída do algoritmo com a figura 46 como imagem de entrada. (a) com $w_{2}=$ -0.6 para todos os canais, (b) $w_{2}=-1$ para todos os canais, (c) $w_{2}=-1$ nos canais RG e GR, e (d) com os canais ruidosos filtrados.

\section{Fonte: própria}

irão aparecer mais e as bordas verdadeiras irão se manter (ver figura 63-(d)). A figura 63-(d) embora livre de alguns artefatos, não é idêntica à figura 63-(a), que possui todos os canais desequilibrados, devido à falta das componentes que foram filtradas. Comparando as figuras 63-(c) e 63-(d) pode-se notar que a filtragem permite uma melhor discriminação das bordas reais na imagem, o que facilitará o processamento visual subsequente.

Adicionalmente, utilizando os parâmetros indicados na tabela 3 e utilizando como imagem de entrada a figura 51 as imagens 64-(a) e 64-(b) foram obtidas para $w_{2}$ igual a -0.6 e -1 , respectivamente.

Dependendo do tamanho do campo receptivo programado no algoritmo, as baixas frequências espaciais da imagem são principalmente extraídas. Assim, quando a imagem do texto é processada, as palavras são reconhecidas como unidades, cada palavra é um retângulo (ver figura 64-(a)). Com esta informação, o cérebro poderia planejar o comprimento e a localização da próxima sacada na leitura. Por outro lado, observando a figura 64-(b) pode-se notar que os espaços entre as palavras são dificilmente perceptíveis, e então 


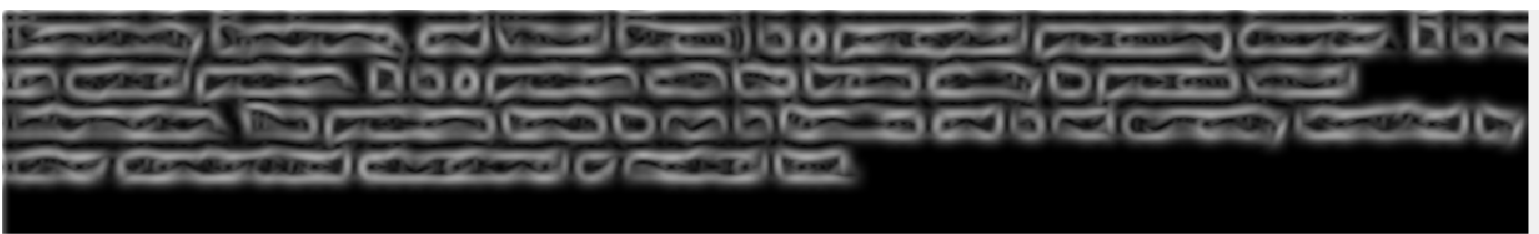

(a)

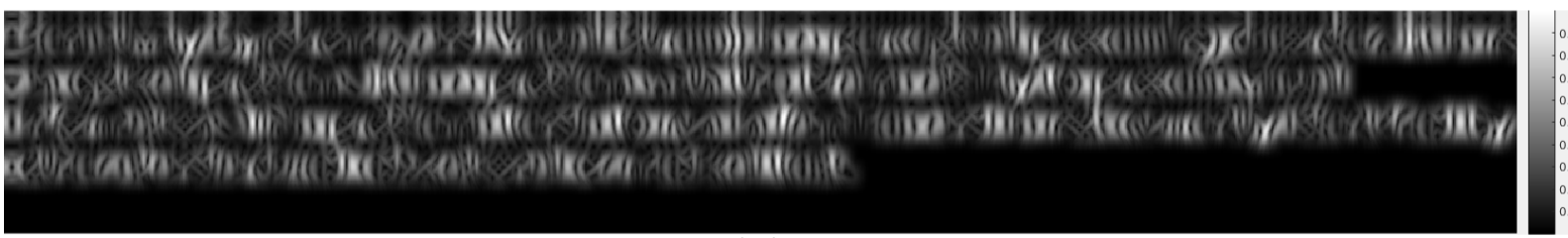

(b)

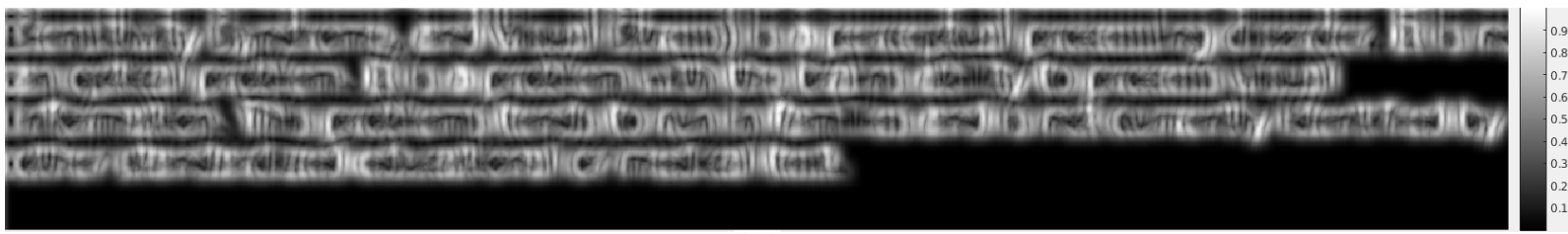

(c)

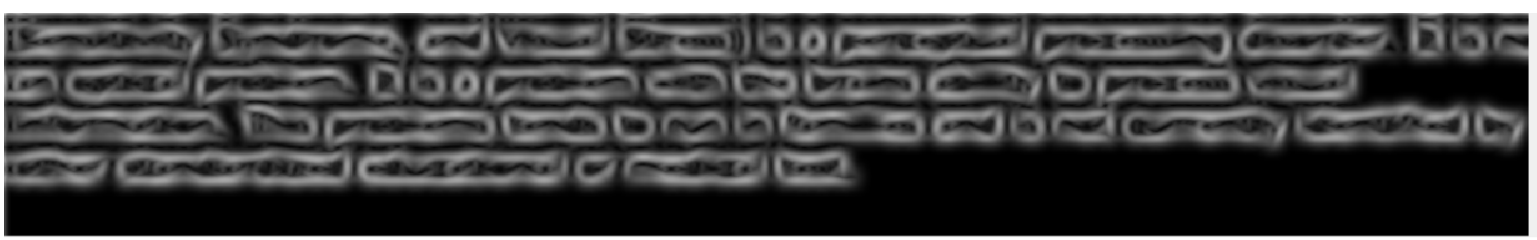

(d)

Figura 64: Imagens de saída do algoritmo com a figura 57 como imagem de entrada. (a) com $w_{2}=$ -0.6 para todos os canais, (b) $w_{2}=-1$ para todos os canais, (c) $w_{2}=-1$ nos canais RG e GR, e (d) com os canais ruidosos filtrados.

\section{Fonte: própria}

as palavras não parecem separadas em blocos.

Se unicamente uma componente de cor possui uma regulação deficiente é possível que a imagem de saída do algoritmo tenha artefatos. Isto pode ser visto na figura 64-(c) onde os blocos de palavras não são facilmente reconhecíveis, o que poderia dificultar a função de programação da sacada. Filtrando os canais equilibrados torna-se possível recuperar as bordas retangulares das palavras, como mostrado na imagem 64-(d).

\subsection{Modelo do fenômeno de Persistência Visual - persistencia_visual.m}

A imagem 54 foi utilizada como entrada no algoritmo que simula a Persistência Visual. A saída do algoritmo persistencia_visual.m quando é simulada a sequência de leitura 
correta e quando um atraso no sistema Magnocelular gera uma deficiência na Supressão sacádica são mostradas nas figuras 65 e 66, respectivamente.

Sensitivity Syndrome, and Visual Stress) is a perceptual processing disorder. It is not

Figura 65: Imagem de saída do algoritmo persistencia_visual.m sob parâmetros normais

Fonte: própria

isesyndronte, anditisual \$tvess) istrepercepaual praptessingactiesorder.dis is nc

Figura 66: Imagem de saída do algoritmo persistencia_visual.m sob parâmetros que simulam uma disfunção do sistema Magnocelular

Fonte: própria

Como pode ser visto da figura 66, que quando acontece um atraso do sinal do caminho magnocelular e a função de supressão sacádica não é realizada adequadamente, nas imagens que chegam ao córtex as letras aparecem sobrepostas e os espaços entre elas ficam confusos; fazendo com que a distinção do comprimento real da palavra não possa ser facilmente diferenciado e a codificação dos caracteres das palavras seja trabalhoso.

Observando a figura 66 pode ser visto que existe uma similaridade com a distorção denominada Halo (mostrada a seguir para facilitar a comparação).

\subsection{Modelo do Controle Ocular - ctrl_ocular.m}

Como descrito, para realizar cada sacada, o algoritmo faz uma comparação entre a informação dada pelo modelo computacional e o próximo ponto de fixação, planejado a partir de um pré-processamento na imagem de entrada que reconhece as frequências espaciais baixas. A diferença entre estas duas posições será a defasagem na localização do próximo ponto de fixação.

Um vídeo mostrando a informação que é adquirida desde que o olho se posiciona no ponto estabelecido pela saída do modelo até que chega no ponto ótimo de fixação foi 


\begin{abstract}
HALO

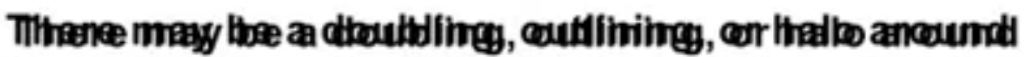

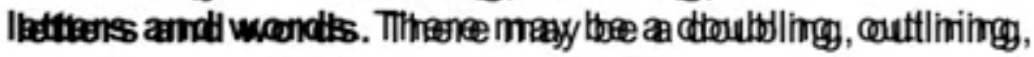

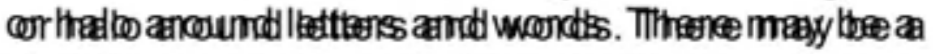

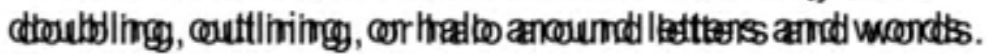

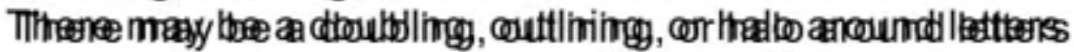

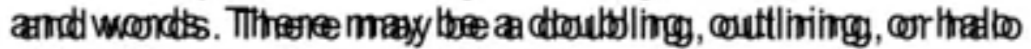

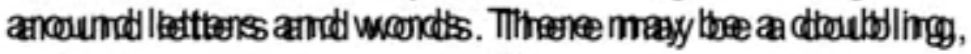

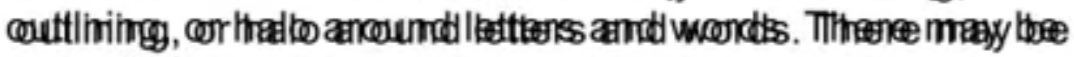

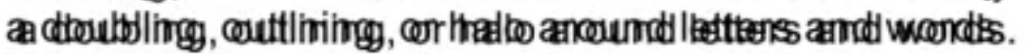

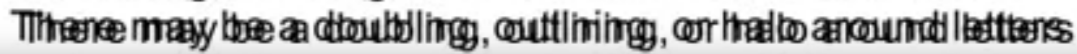

Figura 67: Distorção Halo. As letras ou palavras podem parecer com brilho no fundo ou ter bordas grossas. Podem aparecer também duplicadas

Fonte: Adaptado de [5]

produzido (os vídeos gerados a partir das simulações são fornecidos na informação suplementar da tese). A imagem 68 mostra 1 quadro do vídeo onde se mostra a superposição das letras criada pela defasagem horizontal na posição de ótima fixação. Note-se que na palavra "problem", no foco da imagem, as letras parecem duplicadas. Na periferia da imagem este efeito no se percebe tão facilmente porque a resolução espacial neste lugar é baixa. Quando este efeito se visualiza no tempo é possível notar que o texto parece se movimentar, a imagem fica embaçada e a separação entre palavras na periferia da imagem não é evidente. O resultado obtido pode ser relacionado com as distorções Halo e Shaky relatadas por pessoas com SI, as quais são apresentadas novamente nas figuras 67 e 70 para facilitar a compreensão do leitor; esta comparação fica mais clara ao observar os vídeos.

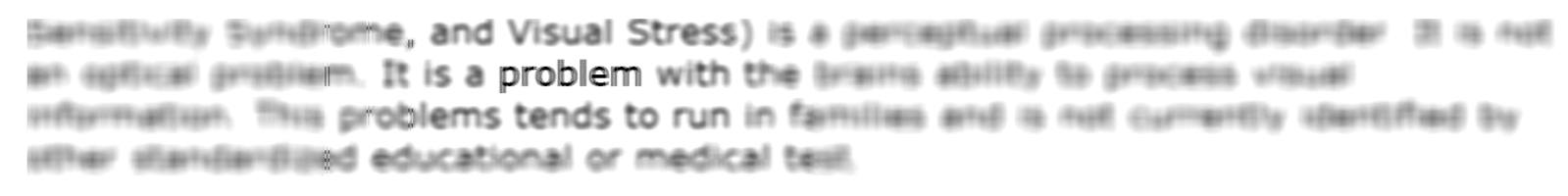

Figura 68: Distorção de sobreposição simulada. Quadro que mostra a distorção criada pela defasagem horizontal na posição de ótima fixação na leitura

Fonte: Própria

Adicionalmente, quando a defasagem acontece de maneira diagonal pode ser gerada uma distorção visual similar à chamada Swirl (figura 71), onde um efeito de redemoinho aparece na periferia da imagem e as letras no foco também parecem duplicadas. Isto pode ser visto na figura 69 obtida a partir de 1 quadro do vídeo gerado na simulação. 


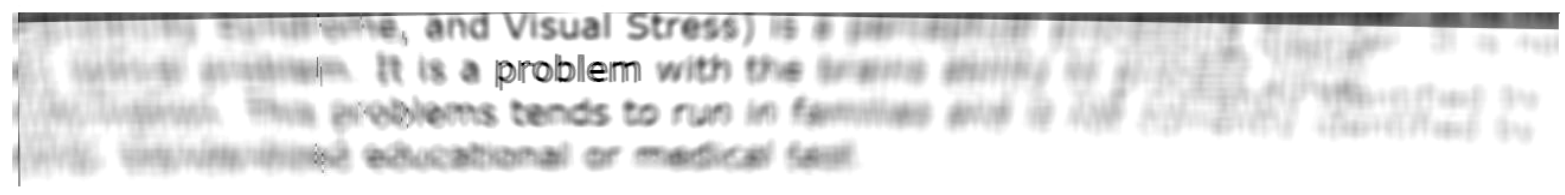

Figura 69: Distorção Swirl simulada. Quadro que mostra a distorção criada pela defasagem horizontal/vertical na posição de ótima fixação na leitura

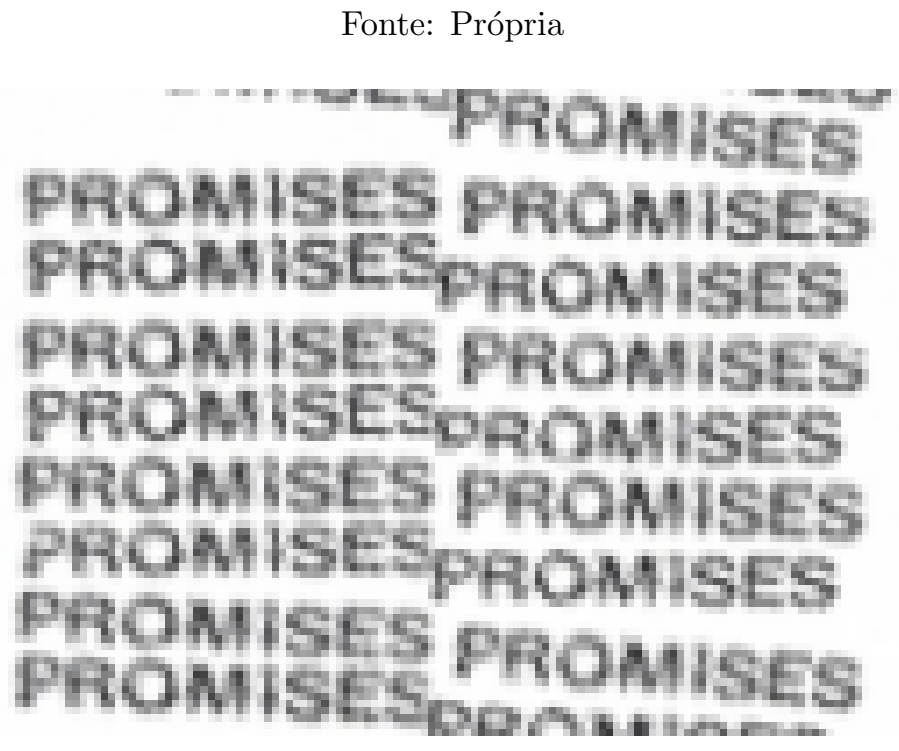

Figura 70: Distorção Shaky. As letras ou palavras podem parecer que se mexem de lado a lado ou de cima pra baixo

Fonte: Adaptado de [5]

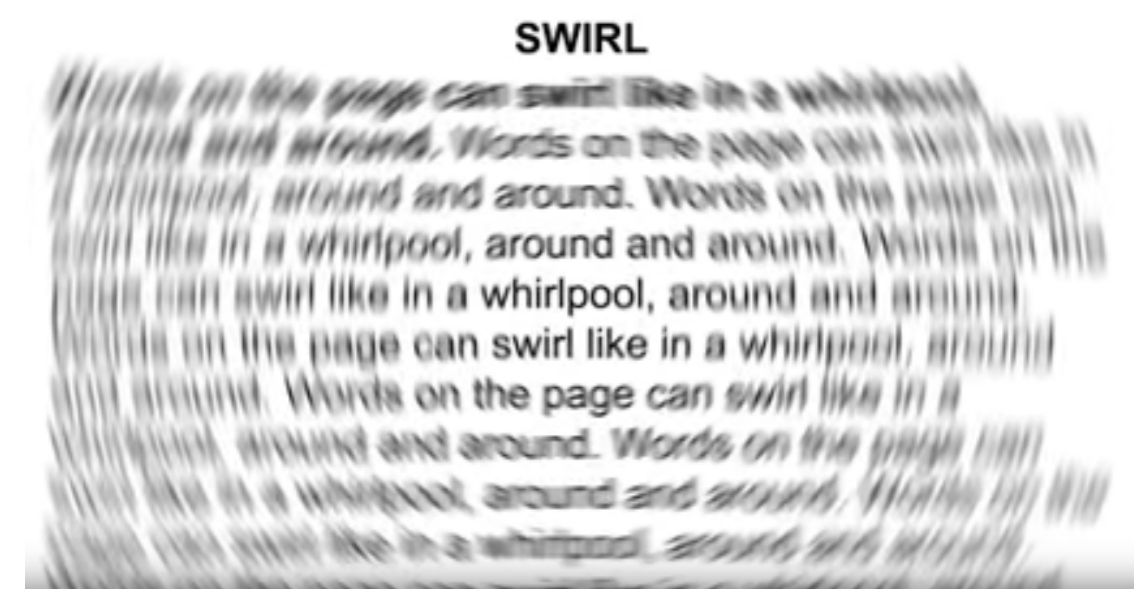

Figura 71: Distorção Swirl. As letras ou palavras podem parecer que se mexem como num redemoinho deixando só o foco estático

Fonte: Adaptado de [5]

Estes resultados indicam que a adquisição de informação enquanto o movimento ocular esta acontecendo, pode gerar distorções visuais. Estas simulações relacionam a falha dos 
movimentos oculares e a sincronicidade para adquirir informação visual com vários tipos de distorções relatadas na SI.

Sugere-se ao leitor comparar os vídeos do material suplementar com o vídeo onde são mostradas as distorções relatadas por indivíduos com SI (ver [5]). Realizando esta comparação realmente pode se apreciar que a distorção obtida na simulação é bastante semelhante às distorções Shaky, Halo e Swirl. Leve-se em consideração que as distorções mostradas no vídeo de Youtube foram geradas a partir de relatos com certo grau de subjetividade e é possível que as pessoas experimentem em maior ou menor grau a superposição ou tremor da imagem, por exemplo. 


\section{DISCUSSÃO}

Na busca bibliográfica para realizar esta investigação, não foram encontradas pesquisas similares. Os principais trabalhos no âmbito científico sobre EV ou Síndrome de Irlen estão focados em pesquisas experimentais que visam quantificar esta condição visual e o efeito dos filtros espectrais $[72,79,92,111,112]$ ou pesquisas descritivas que procuram revisar os trabalhos já realizados sobre o tema [70,80] e/ou explicar ou propôr hipóteses a partir de dados fisiológicos e conjecturas. Por este motivo, não é possível comparar os resultados obtidos nas simulações com outros trabalhos precedentes. Embora dos modelos matemáticos utilizados, inspirados pelo funcionamento do SV, tenham se implementado algoritmos computacionais $[31,60,78,153,236]$ nenhum deles aplicou este conhecimento para simular as condições que poderiam estar se apresentado no SV de pessoas com EV. Assim, a discussão dos resultados obtidos se caracteriza principalmente pela sua interpretação em relação aos sintomas descritos e às hipóteses formuladas. A seguir, os resultados de cada simulação serão discutidos por separado e uma discussão geral será desenvolvida.

\subsection{Modelo da Retina - retina.m}

Como sugerido por Robinson [172] é possível que alguma anormalidade ou suscetibilidade na retina possa ocasionar o sinal ruidoso que perturbe os demais subsistemas visuais. Dentro da retina acontecem uma série de conexões e regulações que podem afetar desde o início a concepção da percepção visual [108]. As células horizontais (HCs) desempenham papéis importantes tanto na compressão da luminância como na regulação dos sinais dos cones [99] (ver seção Fisiologia). Portanto, uma mudança no seu correto funcionamento poderia afetar características da imagem, tais como brilho e reconhecimento de bordas.

O modelo da retina utilizado neste trabalho permitiu modelar algumas interações da retina mediante filtros espaço-temporais. Desta forma, o comportamento das HCs foi 
alterado por meio da modificação do parâmetro $\beta_{h}$ que simula o feedback de luminância das HCs aos fotorreceptores. Pela suscetibilidade a padrões listrados de frequências espaciais médias que apresentam as pessoas com EV [67], as imagens escolhidas para testar o algoritmo foram duas imagens de textos com frequências espaciais médias (figura 43) e baixas (figura 44).

No algoritmo, o parâmetro $\beta_{h}$ influencia tanto o comportamento do filtro $F_{h}$ (5.3) como a compressão logarítmica dos fotorreceptores no bloco Cph (eq. 5.4), portanto quando é simulado o correto funcionamento da retina os contornos de altas frequências devem se manter e a adaptação à luminância deve acontecer [31]. Nas imagens 59-(a) e (b), o brilho do fundo diminuiu, quando comparado com a imagem de entrada 43. Assim, modificar o parâmetro $\beta_{h}$ permitiu ajustar o ganho na frequência, modificando com isto a luminância média da imagem. No caso da imagem 59-(b) o ganho relativamente alto neste filtro $F_{h}$ permite a passagem de mais intensidade lumínica e gera ao mesmo tempo deficiências no reconhecimento de bordas.

Fisiologicamente, o que estaria acontecendo é que as HCs não estariam fornecendo feedback aos fotorreceptores nem às HCs vizinhas. Desta forma, as informações de luminância que são utilizados para obter dados de brilho e frequência espacial não estariam sendo corretamente adaptadas. Note-se que esta adaptação é modulada pela dopamina [176]. Se a disfunção das HCs acontecesse por setores na retina seria possível que regiões da imagem aparecessem com mais luminância e perda de bordas, simulando a distorção conhecida como Washout (ver figura 27).

As pessoas com elevado desconforto visual, apresentam fraca aversão aos padrões listrados de baixas frequências [67]. Assim, em teoria, imagens de textos com menor frequência espacial entre linhas e maior espaço entre as letras, deveriam ser processados pela retina, de tal forma que a imagem de saída possa ser corretamente interpretada processamento visual subsequente. O processamento da imagem 44 permitiu observar que a anterior assunção é plausível. Nas imagens 60-(a) e (b) as letras do texto são perceptíveis e embora na imagem 60-(b) o brilho do fundo seja maior, isto não prejudica a legibilidade das palavras no texto. Como visto, modificar o feedback que as HCs fornecem aos fotorreceptores e outras HCs, pode afetar a intensidade lumínica percebida na imagem e o correto reconhecimento de bordas em imagens de textos com frequências espaciais médias. 


\subsection{Modelo da dilatação da pupila - pupila.m}

Em função das hipóteses propostas, tais como hiperexcitabilidade cortical ou deficiência no sistema magnocelular, várias pesquisas procuram explicar os sintomas do EV estudando as áreas de processamento visual de alto nível ou utilizando estímulos que acionem estes mecanismos visuais $[22,29,48,52,63]$. Poucas pesquisas em indivíduos com EV ou SI têm se focado em estudar os mecanismos retinianos e sinais como o diâmetro pupilar [46, 168, 169]. Everret [73] descreveu que pacientes que relataram sintomas de SI costumavam ter pupilas de um tamanho maior do normal e associou esta observação a uma redução na resposta da retina à luz que permitiria um incremento no nível de iluminação na retina. Além disso, menciona que estes elevados níveis de luz na retina poderiam levar a disfunções nas células de Müller, que ao mesmo tempo afetariam outras funções relacionadas às células amácrinas e às ipRGCs, que estão envolvidas na adaptação do reflexo pupilar.

Com o algoritmo pupila.m procura-se ilustrar o nível de luminância que estaria entrando na retina sob diferentes diâmetros pupilares. Embora a pupila possa-se dilatar por diversos motivos [97], nesta simulação a mudança no diâmetro da pupila foi considerada como unicamente devida a modificações no nível de iluminação.

Como evidenciado pelas imagens 47 e 62 a medida que aumenta o diâmetro da pupila de 2 a $5 \mathrm{~mm}$, o brilho da imagem também aumenta. Se um indivíduo encontra-se numa sala iluminada a 500 lux, e tiver uma dilatação pupilar anormalmente maior, de 4mm em vez de 2.5, por exemplo, ao observar uma folha de texto com contraste preto-branco a quantidade de brilho que estaria enxergando seria relativamente elevada e as letras no texto podem parecem difíceis de entender (ver figura 62-(e)). A condição descrita anteriormente, pode ocasionar elevado desconforto ocular e ser um obstáculo para o correto desenvolvimento da leitura.

\subsection{Modelo de detecção de bordas baseado do meca- nismo de Oponência de Cor - oponencia_cor.m}

Filtrar seletivamente os comprimentos de onda da luz visível alivia os sintomas do EV [19, 22, 79, 84, 95, 222], o que levaria a pensar que o processamento da informação cromática pode estar envolvida na geração dos seus sintomas. A teoria da hiperexcitabi- 
lidade cortical responde a esta relação sugerindo que a filtragem de alguns comprimentos de onda possivelmente diminuem ou redistribuem a quantidade de energia de excitação nas células nervosas, reduzindo a excitação em regiões hiperexcitáveis do córtex [216]. Por outro lado, na hipótese da deficiência no sistema magnocelular foi proposto que filtrar os comprimentos de onda longos melhora o desempenho deste sistema [45] e que filtros amarelos melhoram funções tais como sensibilidade ao movimento, acomodação, vergência e o processo de leitura [160]. No entanto, os mecanismos que explicam estes benefícios não têm sido explicados em detalhe.

O sistema magnocelular embora reconhecido por não participar nos caminhos visuais de percepção de cor, recebe informações dos cones a través da soma neural dos contrastes dos cones-L e M principalmente, sendo sensível a contrastes de luminância [47]. As células ganglionares na retina que constituem o sistema magnocelular são as responsáveis pelo mecanismo acromático de luminância. Foi sugerido que o sistema baseado na luminância é altamente plástico, uma vez que a adaptação cromática (fundos com diferentes cores) influencia sua fase temporal e os pesos de contraste dos cones-L e M, em função da frequência espacial e temporal [202].

As células horizontais (HCs) modulam a resposta à luminância dos fotorreceptores e contribuem à formação do campo receptor antagônico das células bipolares e ganglionares, o que colabora no fenômeno de discriminação do contraste [108,211]. Os sinais dos conesL e M são somados pelas HCs em proporção ao contraste do estímulo [58]; esta resposta aumenta o contraste entre as duas zonas, facilitando a distinção dos contornos [211]. Num estudo onde foi avaliado como a Percepção de Tempo ${ }^{1}$ do flicker detectado pelo cone M ou L depende da frequência temporal e da adaptação cromática foi determinado que os estímulos equivalentes em luminância escolhidos para isolar canais cromáticos podem inadvertidamente gerar sinais lentos no canal de luminância, isto é, a resposta a estímulos que ativam o canal de luminância fica lenta. Além disso, foi mostrado que os sinais lentos possuíam uma origem retiniana nas HCs e nas GC do Magnocelular [200]. Isto indica que as HCs estão envolvidas na percepção de contrastes e de estímulos temporais.

Indivíduos com elevado desconforto visual reportaram uma diminuição na função de sensibilidade ao contraste em grades de frequência espacial media [51] e pessoas com SI mostraram mudanças na percepção de profundidade [91,127]. Assim, se a habilidade de distinguir corretamente as bordas dos objetos está prejudicada, pode ser difícil localizar

\footnotetext{
${ }^{1}$ Percepção de Tempo é a capacidade de executar tarefas em que são necessários julgamentos precisos sobre o curso de tempo dos eventos perceptivos
} 
sua posição espacial; por exemplo, resultaria complicado identificar montanhas sobrepostas em uma paisagem.

O modelo baseado no mecanismo de oponência de cor permite a mudança do parâmetro que simula os pesos de contraste dos cones. As imagens nas que foi testada sua implementação, montanhas superpostas e um texto, permitiram ilustrar como a discriminação de contrastes afeta a deteç̧ão das bordas, e consequentemente o reconhecimento de objetos na cena. Comparando a imagem das montanhas (figura 46) com a imagem de saída 63-(a) pode ser visto que os contornos de todas as montanhas presentes foram detectados. As bordas estão bem definidas e não aparecem objetos estranhos nem distorções na imagem. Isto representaria como uma pessoa sem disfunções na retina observaria os objetos de escala grande de uma paisagem. Em contraste, a imagem (figure 63-(b) apresenta perda de algumas bordas e a aparição de artefatos que poderiam ser confundidos com objetos inexistentes. Isto indicaria que a habilidade de diferenciar uma montanha de outra poderia estar sendo afetada, e até mesmo, a profundidade da cena.

Os filtros espectrais são usados para aliviar os sintomas do EV [218]. Para simular seu efeito, unicamente os pesos dos canais RG e GR foram equilibrados. Na imagem 63(c) aparecem alguns artefatos que dificultam o correto reconhecimento das bordas reais. Esta simulação mostra que, se apenas uma componente de cor for mal regulada, podem ocorrer distorções na imagem processada e a percepção consciente executada no cérebro chegaria a ser inadequada. Por outro lado, a filtragem dos canais perturbados melhora o reconhecimento dos contornos das montanhas. A figura 63-(d) exemplifica o efeito dos filtros espectrais no SV de uma pessoa com EV.

Pessoas com dificuldades na leitura usualmente são diagnosticadas com EV [114]. Estudos mostraram que sujeitos com dificuldades na leitura apresentam movimentos oculares anormais [105,139,186], por exemplo, fazendo sacadas não-ótimas, fixações mais longas e mais regressões [163]. Desta forma no algoritmo, a imagem de um texto é adequada para evidenciar a forma em que a leitura poderia estar sendo percebida por indivíduos com EV quando a discriminação de contrastes, e consequentemente o reconhecimento de bordas, não esta funcionando corretamente.

Pode-se notar na figura 64-(a) que ao processar a imagem sob pesos de contraste desequilibrados as palavras parecem formar blocos. Estes blocos estariam sendo utilizados pelo SV para programar os movimentos oculares na leitura, posto que as características das palavras mudam o padrão dos movimentos oculares [90]. Assim, dependendo das 
habilidades na leitura do indivíduo, o tamanho desses blocos indicaria o comprimento da próxima sacada e permitiria uma fluidez na leitura oral, pela capacidade de diferenciar uma palavra da outra. Quando as peças do texto desaparecem e viram uma única peça comprida, a estratégia que adota o SV poderia ser unicamente ler a informação que esta sendo focada na fóvea sem a ajuda da informação parafoveal. Como resultado desta tática, a fluência na leitura e a habilidade de entender o contexto poderiam ser afetadas. Portanto, poderia acontecer que a imagem processada pelo cérebro seja percebida como na figura 64-(b), onde a separação entre palavras não é evidente.

O efeito da filtragem espectral pode ser analisado observando as figuras 64-(c) e (d). A imagem 64-(c) apresenta alguns vestígios de contornos dos blocos, mas não aparecem notavelmente separados uns de outros. Neste caso também, a fluência na leitura poderia ver-se comprometida. Pode ser visto da figura 64-(d) que remover os canais com sinais alterados torna evidentes as bordas dos blocos de palavras e, segundo o raciocínio desenvolvido, melhoraria a capacidade de leitura.

Deste modo, comparando as imagens de entrada e suas saídas sob diferentes condições é possível verificar que mudanças no correto funcionamento do processamento visual de baixo nível, na retina, podem influenciar a informação que subsequentemente será processada no córtex visual. Se esta informação é ruidosa e não representa o estímulo real, alguns sistemas de controle no cérebro, como os movimentos oculares, podem ser negativamente impactados e/ou distorções perceptuais podem ser geradas. Isto sugere que efetivamente uma possível causa para as distorções geradas no EV pode ser a inabilidade das células horizontais de corretamente regular as contribuições para o contraste dos cones-L e M, ou também que as células ganglionares Parasol não estão conseguindo reconhecer os contrastes de luminância.

Em observadores controle, imagens com alto contraste cromático ou baixo ou nenhum contraste lumínico foram julgadas como desconfortáveis [101]. Isto indicaria que quando os contrastes lumínicos são equilibrados artificialmente, por exemplo, por meio de uma imagem, será gerado desconforto visual em sistemas visuais sem EV. Entretanto, se esta diminuição do contraste é produzida pelo próprio SV causada por uma deficiência na retina, por exemplo na regulação no contraste dos cones, o desconforto visual seria uma condição permanente diminuída unicamente quando os filtros espectrais desequilibram os contrastes lumínicos. Esta hipótese relaciona o efeito dos filtros espectrais com o funcionamento dos cones e o sistema de luminância. 


\subsection{Modelo do Controle Ocular - ctrl_ocular.m}

Como discutido na seção sobre as Anormalidades do sistema oculomotor (ver seção 4.2), a falha nos movimentos oculares não seria a causa do EV, embora estejam correlacionados. Os trabalhos que têm estudado os movimentos oculares em pessoas com dificuldades na leitura estimam principalmente o comprimento da sacada, o tempo de fixação e o número de sacadas e regressões $[105,112,186]$. Além destes movimentos oculares de maior escala, um estudo recente sobre as características das microsacadas ${ }^{2}$ em doenças neurológicas e oftálmicas, mostra que podem ser potenciais indicadores para diagnósticos diferenciais e precoces de múltiplas condições clínicas, desde distúrbios do movimento até transtornos de déficit de atenção e hiperatividade (TDAH), e ambliopia; pois em indivíduos com autismo as microsacadas são mais amplas e em sujeitos com TDAH a taxa de microsacadas é muito mais elevada [20]. Adicionalmente, estudos têm mostrado que as microsacadas estão envolvidas na produção da ilusão de movimento gerada pelo chamado op-art (imagens que geram ilusão de movimento) [150,207]. Na presente pesquisa, trabalhos analisando as microsacadas nas fixações de indivíduos com EV ou SI não foram encontrados. Se os movimentos microsacádicos em pessoas com EV forem anormalmente longos ou similares àqueles que geram a ilusão óptica é possível que, no caso da leitura, o texto pareça em movimento.

O SV está sincronizado de tal forma que a adquisição do estímulo visual acontece de modo discreto a cada fixação. Durante o movimento dos olhos de uma posição a outra acontece o fenômeno de supressão sacádica que não permite que o estímulo visual pareça desfocado ou em movimento. Antes da fixação, a posição da sacada deve ser programada e seu início e posição informada ao sistema de controle motor. Se existe uma discrepância entre o sinal programado e o executado, é possível que a adquisição da informação inicie na posição determinada pelo sistema executor (diferente da programada) e continue sendo adquirida enquanto o olho se movimenta em direção à posição programada. Assim, se depois de começar a adquisição visual o olho continua se movimentando, poderia acontecer o mesmo efeito que ocorre numa fotografia capturada com uma exposição prolongada; imagens desfocadas que parecem em movimento. O modelo de Robinson [171] leva em consideração a defasagem entre a posição da fixação programada e a defasagem na posição executada. Neste caso (curva B na figura 56), a supressão sacádica estaria sendo "enganada" e a sacada teria comportamento de microsacada, pois seria um movimento

\footnotetext{
${ }^{2}$ As microsacadas são movimentos oculares curtos que acontecem durante a fixação, e pensa-se não afetam negativamente a percepção da imagem; foi sugerido que elas favorecem a sensibilidade às bordas e melhoram a resolução espacial [134]
} 
ocular durante a fixação. Os resultados das simulações nas figuras 68 e 69, mostraram que movimentos oculares durante a adquisição da informação visual podem gerar a ilusão de movimento.

Otero indicou que a produção de sacadas e microsacadas possuem um gerador oculomotor comum [151]. Desta forma, se o sistema que controla as sacadas e microsacadas encontra-se afetado, ilusões de movimentos podem ser geradas. O sistema magnocelular esta relacionado ao controle dos movimentos oculares na leitura [36] e foi sugerido que durante as sacadas este é seletivamente suprimido [175]. Portanto, a teoria da deficiência no sistema magnocelular explicaria as anomalias dos movimentos oculares. No entanto, como discutido na seção 7.3, se a imagem gerada na retina é ruidosa poderia comprometer o processamento subsequente e os sistemas de controle de movimentos oculares.

No algoritmo oponencia_cor.m a imagem ruidosa foi gerada a partir da manipulação do parâmetro que permite equilibrar o peso dos contrastes lumínicos dos cones, o que simularia uma situação de equiluminância na imagem. Burr [40] descreveu que estímulos equiluminantes inibem a supressão sacádica em todas as frequências espaciais. Assim, uma falha na regulação da luminância na retina, influenciando o sistema de Luminância, poderia interferir no fenômeno de supressão sacádica.

Aleci no artigo "The game of reading" [17] conclui que num mecanismo tão delicado e sincronizado com a leitura, mesmo uma pequena falha na sua programação ou execução pode torná-la particularmente exigente. Inclusive na presença de acuidade visual adequada, a alternância perfeitamente balanceada da ativação magnocelular e Parvocelular pode ser interrompida ou prejudicada pela percepção anormal da relação espacial dos caracteres no texto, e como mencionado, esta percepção espacial pode ser alterada por falhas na regulação celular na retina.

\subsection{Modelo do fenômeno de Persistência Visual - persistencia_visual.m}

Do mesmo modo em que uma deficiência no sistema magnocelular explicaria as anomalias nos movimentos oculares, este sistema seria o responsável pelo fenômeno da persistência visual [187]. Em retinas de mamíferos a função de evitar a persistência visual foi atribuía a processos na retina mediados pelas células amácrinas que influenciariam as células ganglionares formadoras do sistema magnocelular [174]. 
No algoritmo persistencia_visual.m foi simulada uma assincronia na sequencia do processamento visual na leitura representada na figura 17, caracterizada pela omissão da supressão sacádica devida ao atraso no sistema magnocelular. Esta mostrou que é possível que distorções de sobreposição apareçam se esta sequencia de adquisição e processamento da informação não acontece como esperado. Um estudo para examinar a duração da persistência visual numa sequencia de estímulos com pontos, mostrou que a supressão do estímulo acontece depois de um tempo de espera apropriado e incrementa com a excentricidade do campo visual [61], isto é, começa na fóvea até chegar na periferia. Foi estimado que a persistência visual possui uma duração de 100 a 150 ms [50], desta forma, alterar o sincronismo dos processos de controle das sacadas e fixações poderia manter por um tempo inadequado o estímulo visual, gerando a sobreposição de imagens e um efeito de movimento, no tempo.

Fundamentado no relato de distorções onde o texto aparece sobreposto foi sugerido que o fenômeno de persistência visual poderia estar acontecendo no SV de pessoas com EV ou SI. No entanto, este tipo de efeito também poderia se apresentar a partir de outras disfunções tais como uma alteração dos movimentos oculares (sacadas ou microsacadas), como mencionado.

\subsection{Discussão geral}

Nas discussões dos algoritmos que foram abordadas anteriormente foi mostrado que:

- Uma alteração no funcionamento das células horizontais (HC) pode influir nas características que são identificadas no estímulo visual, tais como luminância, reconhecimento de contrastes e detecção de bordas. Estas observações foram realizadas a partir dos resultados obtidos nos algoritmos retina.m e oponencia_cor.m.

- A simulação pupila.m mostrou que uma abertura maior da pupila sob condições de iluminação padrão pode levar à percepção de excesso de brilho no estímulo visual, dificultando e fazendo desconfortável seu reconhecimento. As deficiências na adaptação da pupila, como discutido, poderiam ser devido a falhas na regulação de processos que envolvem às ipRGCs, células amácrinas ou células de Müller.

- Os movimentos oculares representam um possível foco de produção de distorções; isto, como mostrado pelas simulações ctrl_ocular.m e persistencia_visual.m. No entanto, o controle dos movimentos oculares seriam os encarregados de dirigir estes 
movimentos erráticos. O colículo superior, um dos principais centros de controle dos movimentos oculares, está inervado pelas fibras do sistema magnocelular e, em primates, pelas fibras das ipRGCs. Como discutido, existe a possibilidade que falhas no processamento em níveis iniciais, como nas HCs e ganglionares, ou inclusive nas ipRGCs, produzam o sinais ruidosos que prejudiquem o controle e feedback dos movimentos oculares.

As HCs geram oponência espacial em cones e células bipolares, oponência de cores em cones, células bipolares e subtipos de HCs cromáticas. As ações das HCs se propagam para frente na retina e podem ser identificadas na fisiologia das células ganglionares e na percepção visual. As funções das HCs são sintonizadas por neuromoduladores liberados por outros neurônios da retina, tais como a dopamina liberada pelas células amácrinas [156]. Everett [73] sugeriu que os níveis de dopamina na retina poderiam estar envolvidos na fisiologia da SI, a través do seu papel na modulação das células amácrinas e sua relação com as HCs, ipRGCS e células de Müller.

A dopamina é liberada por um conjunto único de células amácrinas e ativa os receptores de dopamina D1 e D2 distribuídos por toda a retina. A dopamina tem múltiplos papéis na função retiniana relacionados à ritmicidade circadiana, sobrevivência celular e crescimento ocular. A saúde dos neurônios dopaminérgicos depende do recebimento de entradas sinápticas estimuladas pela luz. Algumas doenças que afetam a função fotorreceptora também diminuem a diferença na liberação de dopamina no dia e a noite. Uma redução na dopamina retiniana, como ocorre em pacientes com Parkinson, pode resultar na redução da sensibilidade visual ao contraste [231].

Nas HCs de mamíferos a Dopamina regula a sensibilidade ao flicker e à luz. A ativação dos receptores de dopamina causa uma modificação na transmissão do sinal do cone a neurônios de mais alta ordem [157]. A Dopamina influencia o campo receptivo centro-periferia de neurônios de alta-ordem através da modulação do campo receptivo das HCs [241].

As células amácrinas dopaminérgicas A18, regulam às células amácrinas A2 e às HCs. Além disso, as células A18 influenciam mecanismos de adaptação multiplicativa, como o reflexo pupilar que aumenta o diminui o nível de intensidade da luz, mediado pelas ipRGCs [242]. Foi proposto que na fotofobia, a adaptação à luz mediada pelas ipRGCs é incompatível com o nível real de iluminação incidente na retina, devido a uma hipersensibilidade dos receptores de dopamina [73]. Um aumento nos níveis de iluminação (pela 
deficiência no reflexo pupilar), como consequência, poderia ativar as células de Müller, o que resultaria numa regulação negativa da função celular normal, levando a uma hiperexcitabilidade neuronal [39] e falhas no ciclo visual dos cones [73].

A hipótese que relaciona a Dopamina retinal com os sintomas do EV sugere que sintomas como dores de cabeça e enxaqueca, fotofobia, falhas no controle dos movimentos oculares estariam correlacionado com os níveis de dopamina a través de diferentes mecanismos.

A enxaqueca é um sintoma comum em pacientes com EV [221]; ambas condições têm sido tratadas satisfatoriamente com filtros espectrais [206,218,221]. A Dopamina tem sido implicada na fisiopatologia da enxaqueca e outros desordens associados com aumento à sensibilidade à luz como o TDAH; que também apresenta comorbidade com o EV $[128,234]$. Pensa-se que os receptores de dopamina são hipersensíveis em pessoas que sofrem de enxaquecas [136].

Os movimentos oculares também são afetados por deficiências nos níveis de dopamina na retina. Em pacientes com Parkinson as deficiências nos movimentos oculares sacádicos foram correlacionadas com a integridade do sistema dopaminérgico [159, 231].

Resumindo, sintomas do EV como enxaqueca, fotofobia e movimentos oculares anormais foram correlacionados com os níveis de dopamina na retina. Adicionalmente, sistemas que podem estar envolvidos na geração do EV, como as HCs (que como discutido, podem influenciar outros sintomas do EV) e as ipRGCs (que estão envolvidas no reflexo pupilar e possuem função de percepção consciente) são dependentes de dopamina. 


\section{PARTE IV}

PESQUISAS PROPOSTAS E CONCLUSÕES 


\section{PESQUISAS PROPOSTAS}

Neste capítulo serão recomendadas algumas pesquisas a serem realizadas em indivíduos com EV, a fim de conhecer em mais detalhe a sua fisiologia e coletar informações que ajudem a definir mais adequadamente esta condição visual. Isto, para conseguir propôr hipóteses melhor fundamentadas sobre sua causa. As recomendações são meramente descritivas, os detalhes de cada experimento não serão discutidos.

Para a obtenção de resultados significativos nas pesquisas propostas é de vital importância um diagnóstico cuidadoso, onde as deficiências optométricas e ortópticas sejam corrigidas ou não incluídas, além de descartar comorbidades.

Nos resultados e discussão apresentados anteriormente foi sugerido que a integridade funcional das células na retina podem afetar significativamente processamentos visuais subsequentes, por tanto, os testes propostos, na sua maioria, visam investigar o comportamento e integridade retiniana.

\subsection{Eletrorretinografia (ERG)}

O eletrorretinograma de campo total (ERG) é um teste eletrofisiológico usado para investigar a função da retina. Este registra os potenciais elétricos originados na retina em resposta a estímulos luminosos. Mediante o uso de eletrodos, usualmente na forma de lente de contato, são obtidos os registros de ondas elétricas que correspondem à diferenças de potencial entre o eletrodo na córnea e um eletrodo de referência [155]. Existem uma série de protocolos definidos e nomeados de acordo com o estímulo que é aplicado e o estado da adaptação [138]. Os seis principais são:

1. ERG 0,01 de adaptação ao escuro. Investiga a resposta das células bipolares mediada pelos bastonetes. 
2. ERG 3 de adaptação ao escuro. Investiga respostas combinadas provenientes de fotorreceptores (cones e bastonetes) e células bipolares; dominada pelos bastonetes.

3. ERG 10 de adaptação ao escuro. Investiga a resposta combinada, salientando as ondas-a que refletem a função dos fotorreceptores.

4. Potenciais oscilatórios de adaptação ao escuro. Investiga principalmente as respostas das células amácrinas.

5. ERG 3 de adaptação à luz. Investiga as respostas do sistema de cones; as ondas-a surgem dos cones, e dos cones(Off)-células bipolares; a onda-b provém dos cones(OnOff)-células bipolares.

6. ERG com flicker a $30 \mathrm{~Hz}$ de adaptação à luz. Sensível à reposta do caminho que leva a informação dos cones (parvo).

A Sociedade Internacional para Eletrofisiologia Clínica da Visão (ISCEV) padronizou os protocolos clínicos básicos de ERG, para que pudessem ser obtido resultados comparáveis no mundo. Itens como características do estímulo, calibração do equipamento, protocolo clínico e descrições dos resultados que podem ser obtidos são descritos no "ISCEV Standard for full-field clinical electroretinography" [138].

Existem outros protocolos de ERG que também são amplamente usados e servem para investigar as funções das células ganglionares, bastonetes, cones-S e funções das camadas da retina. Estes protocolos são enunciados e referenciados na tabela 2 de McCulloch (2015) [138]

Pesquisas utilizando ERG em indivíduos com EV ou SI não foram encontradas na busca bibliográfica deste trabalho. Unicamente uma pesquisa deste tipo em sujeitos com Desconforto Visual foi identificada. Na pequisa desenvolvida por Ridder et al. [169] foi utilizado o ERG com estímulo de flicker a $30 \mathrm{~Hz}$ para estimular diferentes tipos de cones. Os resultados obtidos nesse estudo não refletem de modo fidedigno o que acontece nas retinas de pacientes com EV, pois embora tenha sido realizada uma avaliação optométrica e os pacientes relataram desconforto visual, um diagnóstico mais específico para EV ou SI não foi efetuado. Assim, é importante contar com estudos sobre a função retiniana em indivíduos adequadamente diagnosticados com EV. 


\subsection{Pupilometria cromática}

Os métodos de pupilometria cromática visam avaliar a saúde dos fotorreceptores e as ipRGCs, medindo as respostas pupilares sob diferentes comprimentos de onda e intensidades de luz, o que faz possível diferenciar as contribuições de bastonetes, cones e ipRGCs no reflexo pupilar à luz [177]. Os fotorreceptores da retina externa e os dependentes de melanopsina contribuem diferencialmente para o reflexo pupilar à luz. As respostas pupilares dependentes da melanopsina são sensíveis a comprimentos de onda curtos e possuem um limiar de ativação maior, quando comparada com o dos cones e bastonetes. Adicionalmente, os cones e bastonetes dominam o componente fásico da resposta pupilar após o estímulo luminoso. Em contraste, as respostas dependentes de melanopsina são muito mais lentas e sustentadas, e dominam a componente tônica do reflexo pupilar durante a exposição a estímulos luminosos contínuos de alta irradiância. Em consequência, as respostas dos cones, bastonetes e fotorreceptores dependentes de melanopsina podem ser avaliados diferencialmente a partir do reflexo pupilar à luz [177].

Os estímulos usados na pupilometria podem variar em tamanho, brilho, duração e comprimento de onda. Os paradigmas de estímulo determinam se as respostas dos bastonetes induzidas pela rodopsina, as respostas dos cones induzidas pela opsina ou as respostas ipRGC dirigidas pela melanopsina são principalmente extraídas. A iluminação de fundo, o estado de adaptação e as instruções aos participantes influenciarão os resultados. No artigo de 2019, "Standards in pupillography"por Kelbsch [104] é recomendado um conjunto mínimo de variáveis a serem utilizadas na pupilometria, que devem ser especificadas nas metodologias das pesquisas.

Os métodos de pupilometria cromática podem detectar a disfunção de fotorreceptores em doenças que afetam a retina externa ou a interna. A função das ipRGCs pode ser avaliada através da medição da resposta pupilar pós-iluminação (PIPR) após a exposição a um estímulo de luz azul brilhante. A PIPR após a adaptação ao escuro está reduzida em pacientes com doenças do nervo óptico, por exemplo, glaucoma. Similarmente, as respostas pupilares fásicas e a PIPR estão reduzidas em pacientes com esclerose múltipla (onde os filtros espectrais melhoraram a leitura e a inspeção visual [233]) e doença de Parkinson (onde foram encontradas falhas no movimentos oculares e no sistema dopaminérgico [159]) [100,141]. No glaucoma, as respostas pupilares dependentes de melanopsina foram correlacionadas com a perda do campo visual e com a anatomia do dano do nervo óptico, sugerindo que os métodos pupilométricos podem ser usados para estimar o 
grau de dano das ipRGCs e células ganglionares convencionais [177]. Desta forma, mediante a pupilometria seria possível avaliar o estado dos fotorreceptores da retina (cones, bastonetes e ipRGCs) em sujeitos com EV.

Como desvantagem, embora os métodos de pupilometria cromática possam ser usados para localizar danos na retina externa ou interna, eles não fornecem informações sobre o tipo específico de doença. Pois existem doenças diferentes com respostas pupilométricas similares [177]. A resposta pupilar também pode ser afetada por diversos tipos de medicamentos, privação do sono ou fase circadiana, o que indica que os testes de pupilometria cromática não são unicamente influenciados pela estimulação dos fotorreceptores da retina, mas também por outras vias biológicas e processos da doença [177].

\subsection{Níveis de Dopamina}

Atualmente, a maioria das pesquisas que analisam os níveis de dopamina na retina utilizam modelos animais. É provável que na próxima década a manipulação genética de animais de laboratório irão oferecer grandes avanços na compreensão de como a neuromodulação dopaminérgica modifica o processamento visual [176]. Em humanos, a aplicação da técnica de tomografia computadorizada de emissão de fóton único transportador de dopamina (DAT-SPECT) tem sido utilizada para detectar distúrbios degenerativos como a doença de Parkinson $[26,159]$. Esta técnica consegue mostrar a existência de uma degeneração no sistema dopaminérgico no cérebro, que poderia estar relacionada aos níveis de dopamina na retina. Assim, esta técnica não seria muito útil para avaliar diretamente os níveis ou receptores de dopamina na retina de pessoas com EV. Consequentemente, por enquanto, não seria possível medir direta e não-invasivamente as interações dopaminérgicas na retina humana.

\subsection{Conectividade das redes de matéria branca no cérebro}

Estudos recentes com Imagens por Ressonância Magnética (MRI) têm analisado a conectividade das redes de matéria branca no cérebro de indivíduos com dislexia e dificuldades na leitura $[119,129]$. Algumas áreas cerebrais como a estrutura da substância branca temporal-parietal esquerda tem sido associada às habilidades de leitura em crianças. No 
estudo realizado por Lebel et al. (2019) os resultados sugeriram que existe um atraso no desenvolvimento da substância branca em leitores sem fluência e mostraram diferenças maturacionais entre crianças com diferentes tipos de comprometimento da leitura. Adicionalmente, numa pesquisa feita por Lou et al. (2019) [129] esta mesma conectividade foi avaliada em sujeitos com dislexia. Neste estudo identificou-se uma diminuição nas redes de conexão do córtex occipital-temporal esquerdo e do córtex temporo-parietal.

Na pesquisa realizada por Lebel, os sujeitos estudados foram recrutados a partir de referências da comunidade, foram estudadas aquelas crianças que apresentaram deficiências na leitura. O critério de exclusão foi a presença de distúrbios emocionais, distúrbios neurogenéticos clinicamente aparentes, lesão cerebral, distúrbios sensoriais ou desvantagem social, cultural ou econômica. Consequentemente, existe a possibilidade que indivíduos com EV participaram nesta pesquisa. Desta forma, seria interessante realizar estudos deste tipo em sujeitos corretamente diagnosticados com EV, para assim identificar se o desenvolvimento de áreas cerebrais relacionadas à leitura estão subdesenvolvidas nos cérebros de sujeitos com EV. Com isto, e comparando estudos feitos em disléxicos, seria possível definir se existe uma relação anatômica cerebral entre indivíduos com EV e Dislexia.

\subsection{Microsacadas}

Existe a possibilidade de que indivíduos com EV apresentem microsacadas irregulares e anormalmente longas que estejam produzindo as distorções relatadas. Para medir as microsacadas, atualmente estão disponíveis diferentes tipos de eye-trackers de alta resolução e modelos matemáticos para detectá-las corretamente [142]. No artigo "A Compact Field Guide to the Study of Microsaccades: Challenges and Functions" são descritos os desafios associados ao estudo das microsacadas, tais como as dificuldades em (1) registrar pequenos movimentos oculares, (2) extrapolar os resultados obtidos sob condições artificiais de laboratório, e (3) determinar exatamente como as microsacadas movimentam o estímulo na retina. Além disso, indica-se a necessidade de desenvolver procedimentos melhores e mais padronizados para garantir gravações de alta qualidade. Desta forma, a medição destes pequenos movimentos oculares poderia esclarecer como algumas das distorções visuais no EV são produzidas. 


\section{CONCLUSÕES}

Este trabalho integra a informação suficiente para que quem estiver interessado no tema, lendo esta tese, possa adquirir o conhecimento necessário para entender de que se trata o EV, qual é o tratamento atualmente disponível, como se faz o seu diagnóstico, e quais mecanismos estão possivelmente envolvidos na geração dos sintomas. Além disso, a partir dos resultados obtidos e discutidos, os testes sugeridos podem despertar o interesse de outros pesquisadores e avançar na descrição desta condição visual.

A simulação computacional dos processos biológicos é uma ferramenta muito útil para entender e ilustrar os processos que acontecem no sistema visual, por exemplo. Neste trabalho, permitiram observar o comportamento de funções da retina, como a equalização da luminância e do contraste sob condições normais e alteradas. Os resultados das simulações possibilitaram a discussão sobre a plausibilidade de que subsistemas visuais, tais como as interações celulares na retina, estivessem participando na geração de alguns dos sintomas do EV.

A deficiência no processamento visual de baixo nível na retina, como hipótese da origem do EV, deveria ser considerada mais fortemente. Pois como discutido, as células da retina, como as ipRGCs ou as HCs, têm funções que influenciam uma série de processamentos e sistemas de feedback que podem estar operando inadequadamente a partir dos sinais ruidosos gerados na retina.

As funções das ipRGCs vem sendo pesquisadas arduamente em anos recentes. Seu papel na visão geradora de imagem consciente ainda não esta bem estabelecida. Entretanto, a partir das funções de que lhe estão sendo atribuídas (ver figura 38) é possível hipotetizar que seu mal funcionamento poderia estar envolvido na origem dos sintomas do EV. Devido à sua relação com os comprimentos de onda curtos, os filtros espectrais que transmitem ou absorvem estes comprimentos de onda poderiam estar beneficiando o funcionamento das ipRGCs. Como consequência da recente descrição das ipRGCs, modelos matemáticos que representem suas funções e interação com outras células na retina não 
têm sido desenvolvidos, o que impede a implementação de algoritmos matemáticos que simulem diretamente seu funcionamento. No entanto, funções nas que elas participam, como o reflexo pupilar, podem ser simuladas e a partir disso definir uma correlação.

Assim como diferentes funções continuam se estabelecendo nas ipRGCs, existe a possibilidade de que ainda não tenham sido descobertas funções ou células que sejam importantes para determinar a causa do EV. Por exemplo, não se tem certeza da presença das células ganglionares de direção seletiva (DSGC) na retina humana, e no caso de estarem presentes, quais consequências traria sua deficiência na percepção visual. Em vista disso é importante que a pesquisa básica em fisiologia da retina continue avançando e os pesquisadores em EV estejam ao par dos novos descobrimentos.

O neuromodulador dopamina na retina pode alterar diversos mecanismos de comunicação entre os fotorreceptores, HCs, amácrinas e ganglionares. O que leva a inferir que sua desregulação pode afetar o processamentos visuais de baixo nível e subsequentes. Embora neste momento sua avaliação direta na retina humana não seja possível, mais pesquisas relacionando este neuromodulador com as funções visuais no EV são necessárias. A desregulação da dopamina na retina tem o potencial de ser a origem de muitos sintomas do EV. 


\section{REFERÊNCIAS}

[1] Aberração cromática longitudinal e lateral. https://photographylife.com/what-ischromatic-aberration. Acessado em: 2019-06-27.

[2] Arnold j wilkins . re: Irlen syndrome: expensive lenses for this ill defined syndrome exploit patients. (2014). https://www.bmj.com/content/349/bmj.g4872/rr/762143. Acessado em: 2019-06-10.

[3] Campo receptivo das células ganglionares. https://project.inria.fr/keops/what-areretinal -receptive-fields/ . Acessado em: 2019-05-16.

[4] Células bipolares. http://retina.umh.es/webvision/spanish/otrascel.html . Acessado em: 2017-05-15.

[5] Distorções na síndrome de irlen. https://irlen.com/what-is-irlen-syndrome/. Acessado em: 2019-05-30.

[6] Distribuição dos fotorreceptores na retina. https://opsistx.com/photoreceptors/ . Acessado em: 2019-05-18.

[7] Ilusões ópticas. https://dotwe.wordpress.com/2014/11/26/illusion-the-design-life/. Acessado em: 2019-06-30.

[8] Morfologia dos fotorreceptores. https://www.scoop.it/topic/mutaciongenetica/p/4078784171/2017/05/10/los-fotorreceptores-esas-fascinantes-celulas . Acessado em: 2019-05-15.

[9] Norma brasileira nbr5413 para iluminação de interiores. http://ftp.demec.ufpr.br/disciplinas/TM802/NBR5413.pdf. Acessado em: 2019$07-20$.

[10] O sistema visual humano. https://www.psiquiatriageral.com.br/cerebro/figuras.htm. Acessado em: 2017-05-30.

[11] Overlays e lentes coloridos. https://www.migraine-dyslexia.com/Meares-IrlenSyndrome.htm. Acessado em: 2019-06-05.

[12] Partes do olho humano. http://hob.med.br/como-funciona-o-olho-humano/ . Acessado em: 2019-05-21.

[13] Vias what e where no cérebro. http://www.cns.nyu.edu/david/courses/perception /lecturenotes/what-where/what-where.html. Acessado em: 2017-05-20.

[14] P. Ahnelt and H. Kolb. Horizontal cells and cone photoreceptors in primate retina: a golgi-light microscopic study of spectral connectivity. Journal of Comparative Neurology, 343(3):387-405, 1994. 
[15] N. Z. Al Dahhan, J. R. Kirby, D. C. Brien, and D. P. Munoz. Eye movements and articulations during a letter naming speed task: Children with and without dyslexia. Journal of Learning disabilities, 50(3):275-285, 2017.

[16] C. Aleci. Colored filters and dyslexia. a quick gliding over myth and (possible) reality. Neuro-Ophthalmol. Vis. Neurosci, 1:18-21, 2014.

[17] C. Aleci. The game of reading: When saccades and fixations play on a seesaw. American Journal of Medical and Biological Research, 2(2):31-36, 2014.

[18] C. Aleci. A brief consideration of the paper by suttle et al. about the repeatability of tinted lenses. Ophthalmic and Physiological Optics, 38(4):468-469, 2018.

[19] C. D. d. C. AlenCAR, J. L. BARBOSA Junior, R. Q. Guimarães, M. R. GUIMARÃES, and A. F. SILVA. Coloured overlays improve reading performance in people suffering from visual stress. In Conference: II FORUM MUNDIAL DISLEXIA (II World Dyslexia Forum)-UFMG, At Belo Horizonte. Pridobljeno, volume 13, page 2017, 2014.

[20] R. G. Alexander, S. L. Macknik, and S. Martinez-Conde. Microsaccade characteristics in neurological and ophthalmic disease. Frontiers in neurology, 9:144, 2018.

[21] A. E. Allen, F. P. Martial, and R. J. Lucas. Form vision from melanopsin in humans. Nature communications, 10(1):2274, 2019.

[22] P. M. Allen, S. Dedi, D. Kumar, T. Patel, M. Aloo, and A. J. Wilkins. Accommodation, pattern glare, and coloured overlays. Perception, 41(12):1458-1467, 2012.

[23] P. M. Allen, A. Hussain, C. Usherwood, and A. J. Wilkins. Pattern-related visual stress, chromaticity, and accommodation. Investigative Ophthalmology \& Visual Science, 51(12):6843-6849, 2010.

[24] A. Amini, K. Digre, and W. T. Couldwell. Photophobia in a blind patient: an alternate visual pathway: case report. Journal of neurosurgery, 105(5):765-768, 2006.

[25] P. Arbelaez, M. Maire, C. Fowlkes, and J. Malik. Contour detection and hierarchical image segmentation. IEEE transactions on pattern analysis and machine intelligence, 33(5):898-916, 2010.

[26] F. Ba and W. W. Martin. Dopamine transporter imaging as a diagnostic tool for parkinsonism and related disorders in clinical practice. Parkinsonism \& related disorders, 21(2):87-94, 2015.

[27] C. L. Barberini, M. R. Cohen, B. A. Wandell, and W. T. Newsome. Cone signal interactions in direction-selective neurons in the middle temporal visual area (mt). Journal of Vision, 5(7):1-1, 2005.

[28] G. Barbolini, A. Lazzerini, L. Pini, F. Steiner, G. Del Vecchio, M. Migaldi, and G. Cavalllini. Malfunctioning cones and remedial tinted filters. Ophta, 2(209):101$105,2009$. 
[29] G. Bargary, M. Furlan, P. J. Raynham, J. L. Barbur, and A. T. Smith. Cortical hyperexcitability and sensitivity to discomfort glare. Neuropsychologia, 69:194-200, 2015.

[30] P. A. Barrionuevo and D. Cao. Contributions of rhodopsin, cone opsins, and melanopsin to postreceptoral pathways inferred from natural image statistics. JOSA A, 31(4):A131-A139, 2014.

[31] A. Benoit, A. Caplier, B. Durette, and J. Hérault. Using human visual system modeling for bio-inspired low level image processing. Computer vision and Image understanding, 114(7):758-773, 2010.

[32] P. S. Bernstein, B. Li, P. P. Vachali, A. Gorusupudi, R. Shyam, B. S. Henriksen, and J. M. Nolan. Lutein, zeaxanthin, and meso-zeaxanthin: The basic and clinical science underlying carotenoid-based nutritional interventions against ocular disease. Progress in retinal and eye research, 50:34-66, 2016.

[33] M. Biscaldi, S. Gezeck, and V. Stuhr. Poor saccadic control correlates with dyslexia. Neuropsychologia, 36(11):1189-1202, 1998.

[34] J. Bouldoukian, A. J. Wilkins, and B. J. Evans. Randomised controlled trial of the effect of coloured overlays on the rate of reading of people with specific learning difficulties. Ophthalmic and Physiological Optics, 22(1):55-60, 2002.

[35] D. H. Brainard, A. Roorda, Y. Yamauchi, J. B. Calderone, A. Metha, M. Neitz, J. Neitz, D. R. Williams, and G. H. Jacobs. Functional consequences of the relative numbers of 1 and m cones. JOSA A, 17(3):607-614, 2000.

[36] B. G. Breitmeyer. The roles of sustained (p) and transient (m) channels in reading and reading disability. In Studies in visual information processing, volume 3, pages 13-31. Elsevier, 1993.

[37] B. G. Breitmeyer and M. C. Williams. Effects of isoluminant-background color on metacontrast and stroboscopic motion: Interactions between sustained $(\mathrm{p})$ and transient (m) channels. Vision research, 30(7):1069-1075, 1990.

[38] A. Bringmann, T. Pannicke, J. Grosche, M. Francke, P. Wiedemann, S. N. Skatchkov, N. N. Osborne, and A. Reichenbach. Müller cells in the healthy and diseased retina. Progress in retinal and eye research, 25(4):397-424, 2006.

[39] A. Bringmann and P. Wiedemann. Müller glial cells in retinal disease. Ophthalmologica, 227(1):1-19, 2012.

[40] D. C. Burr, M. C. Morrone, and J. Ross. Selective suppression of the magnocellular visual pathway during saccadic eye movements. Nature, 371(6497):511, 1994.

[41] G. Capovilla, F. Beccaria, A. Romeo, P. Veggiotti, R. Canger, and F. Paladin. Effectiveness of a particular blue lens on photoparoxysmal response in photosensitive epileptic patients. The Italian Journal of Neurological Sciences, 20(3):161-166, 1999.

[42] G. Cardona, R. Borràs, E. Peris, and M. Castañé. A placebo-controlled trial of tinted lenses in adolescents with good and poor academic performance: reading accuracy and speed. Journal of Optometry, 3(2):94-101, 2010. 
[43] V. Casagrande. A third parallel visual pathway to primate area v1. Trends in neurosciences, 17(7):305-310, 1994.

[44] G. Chahine and B. Krekelberg. Cortical contributions to saccadic suppression. PloS one, 4(9):e6900, 2009.

[45] C. Chase, A. Ashourzadeh, C. Kelly, S. Monfette, and K. Kinsey. Can the magnocellular pathway read? evidence from studies of color. Vision Research, 43(10):1211$1222,2003$.

[46] C. Chase, R. F. Dougherty, N. Ray, S. Fowler, and J. Stein. L/m speed-matching ratio predicts reading in children. Optometry and Vision Science, 84(3):229-236, 2007.

[47] S. Chatterjee and E. M. Callaway. S cone contributions to the magnocellular visual pathway in macaque monkey. Neuron, 35(6):1135-1146, 2002.

[48] B. D. Chouinard, C. I. Zhou, S. Hrybouski, E. S. Kim, and J. Cummine. A functional neuroimaging case study of meares-irlen syndrome/visual stress (misvis). Brain topography, 25(3):293-307, 2012.

[49] C. Clisby, M. Fowler, G. Hebb, J. Walters, P. Southcott, and J. Stein. Outcome of treatment of visual problems in children with reading difficulties. Professional Association of Teachers in Special Situations (PATOSS) Bulletin: Worcestershire, $U K$, pages 9-14, 2000.

[50] M. Coltheart. Iconic memory and visible persistence. Perception \& psychophysics, $27(3): 183-228,1980$.

[51] E. Conlon, W. Lovegrove, S. Barker, and E. Chekaluk. Visual discomfort: the influence of spatial frequency. Perception, 30(5):571-581, 2001.

[52] E. G. Conlon, M. A. Sanders, and C. M. Wright. Relationships between global motion and global form processing, practice, cognitive and visual processing in adults with dyslexia or visual discomfort. Neuropsychologia, 47(3):907-915, 2009.

[53] B. R. Conway, R. T. Eskew Jr, P. R. Martin, and A. Stockman. A tour of contemporary color vision research. Vision research, 151:2-6, 2018.

[54] M. L. Conway, B. J. Evans, J. C. Evans, and C. M. Suttle. Does gender influence colour choice in the treatment of visual stress? PloS one, 11(9):e0163326, 2016.

[55] M. M. Cortez, N. A. Rea, and K. Brennan. Pupil cycle time distinguishes migraineurs from subjects without headache. Frontiers in neurology, 10:478, 2019.

[56] J. D. Crook, C. M. Davenport, B. B. Peterson, O. S. Packer, P. B. Detwiler, and D. M. Dacey. Parallel on and off cone bipolar inputs establish spatially coextensive receptive field structure of blue-yellow ganglion cells in primate retina. Journal of Neuroscience, 29(26):8372-8387, 2009.

[57] J. D. Crook, M. B. Manookin, O. S. Packer, and D. M. Dacey. Horizontal cell feedback without cone type-selective inhibition mediates "red-green" color opponency in midget ganglion cells of the primate retina. Journal of Neuroscience, 31(5):1762$1772,2011$. 
[58] D. M. Dacey, L. C. Diller, J. Verweij, and D. R. Williams. Physiology of l-and $\mathrm{m}$-cone inputs to h1 horizontal cells in the primate retina. JOSA A, 17(3):589-596, 2000 .

[59] D. M. Dacey, H.-W. Liao, B. B. Peterson, F. R. Robinson, V. C. Smith, J. Pokorny, K.-W. Yau, and P. D. Gamlin. Melanopsin-expressing ganglion cells in primate retina signal colour and irradiance and project to the lgn. Nature, 433(7027):749, 2005.

[60] J. Del Punta, K. Rodriguez, G. Gasaneo, and S. Bouzat. Models for saccadic motion and postsaccadic oscillations. Physical Review E, 99(3):032422, 2019.

[61] V. Di Lollo and J. H. Hogben. Suppression of visible persistence. Journal of Experimental Psychology: Human Perception and Performance, 11(3):304, 1985.

[62] S. A. Drew, E. Borsting, L. R. Stark, and C. Chase. Chromatic aberration, accommodation, and color preference in asthenopia. Optometry and Vision Science, 89(7):E1059-E1067, 2012.

[63] L. Ebrahimi, H. Pouretemad, A. Khatibi, and J. Stein. Magnocellular based visual motion training improves reading in persian. Scientific reports, 9, 2019.

[64] J. L. Ecker, O. N. Dumitrescu, K. Y. Wong, N. M. Alam, S.-K. Chen, T. LeGates, J. M. Renna, G. T. Prusky, D. M. Berson, and S. Hattar. Melanopsin-expressing retinal ganglion-cell photoreceptors: cellular diversity and role in pattern vision. Neuron, 67(1):49-60, 2010.

[65] D. B. Elliot and J. M. Wood. Coloured filters show gender differences and poor repeatability. Ophthalmic and Physiological Optics, 37(6):635-639, 2017.

[66] B. Evans, R. Patel, and A. Wilkins. Optometric function in visually sensitive migraine before and after treatment with tinted spectacles. Ophthalmic and Physiological Optics, 22(2):130-142, 2002.

[67] B. Evans and S. Stevenson. The pattern glare test: a review and determination of normative values. Ophthalmic and Physiological Optics, 28(4):295-309, 2008.

[68] B. Evans, A. Wilkins, J. Brown, A. Busby, A. Wingfield, R. Jeanes, and J. Bald. A preliminary investigation into the aetiology of meares - irlen syndrome. Ophthalmic and Physiological Optics, 16(4):286-296, 1996.

[69] B. J. Evans. The need for optometric investigation in suspected meares-irlen syndrome or visual stress. Ophthalmic and Physiological Optics, 25(4):363-370, 2005.

[70] B. J. Evans and P. M. Allen. A systematic review of controlled trials on visual stress using intuitive overlays or the intuitive colorimeter. Journal of optometry, 9(4):205-218, 2016.

[71] B. J. Evans and P. M. Allen. Coloured filters and visual stress. Ophthalmic \& physiological optics: the journal of the British College of Ophthalmic Opticians (Optometrists), 38(2):203-204, 2018. 
[72] B. J. Evans, P. M. Allen, and A. J. Wilkins. A delphi study to develop practical diagnostic guidelines for visual stress (pattern-related visual stress). Journal of optometry, 10(3):161-168, 2017.

[73] D. Everett. The association between macular pigment optical density and glare recovery time with selected macular degeneration and ocular vascular perfusion risk factors. PhD thesis, Doctoral dissertation, Aston University, 2015.

[74] C. Fisher, E. Chekaluk, and J. Irwin. Impaired driving performance as evidence of a magnocellular deficit in dyslexia and visual stress. Dyslexia, 21(4):350-360, 2015.

[75] D. Flitcroft. A neural and computational model for the chromatic control of accommodation. Visual neuroscience, 5(6):547-555, 1990.

[76] K. N. Fong, W. Ma, H. Pang, P. P. Tang, and L. L. Law. Immediate effects of coloured overlays on the reading performance of preschool children with an autism spectrum disorder using eye tracking. Research in developmental disabilities, 89:141$148,2019$.

[77] M. Fowler, A. Mason, A. Richardson, and J. Stein. Yellow spectacles to improve vision in children with binocular amblyopia. The Lancet, 338(8775):1109-1110, 1991.

[78] S.-B. Gao, K.-F. Yang, C.-Y. Li, and Y.-J. Li. Color constancy using doubleopponency. IEEE transactions on pattern analysis and machine intelligence, 37(10):1973-1985, 2015.

[79] A. C. O. Garcia, T. M. Momensohn-Santos, and D. de Araújo Vilhena. Effects of spectral overlays on reading performance of brazilian elementary school children. Folia Phoniatrica et Logopaedica, 69(5-6):219-225, 2017.

[80] P. G. Griffiths, R. H. Taylor, L. M. Henderson, and B. T. Barrett. The effect of coloured overlays and lenses on reading: a systematic review of the literature. Ophthalmic and Physiological Optics, 36(5):519-544, 2016.

[81] M. R. Guimarães and I. R. Guimarães. Aprendizagem e leitura-síndrome de irlen. 2013.

[82] V. D. d. A. L. R. G. . G. R. Q. Guimarães Marcia R., Arroyave Ana I. Spectral overlays improve eye movement functions in iliterate children: reading numbers evaluation. 6to Congresso Brasileiro de Neurociências da Visão.

[83] A. C. Guyton and J. E. Hall. Human physiology and mechanisms of disease. 1992.

[84] P. Harries, R. Hall, N. Ray, and J. Stein. Using coloured filters to reduce the symptoms of visual stress in children with reading delay. Scandinavian journal of occupational therapy, 22(2):153-160, 2015.

[85] S. H. Hendry and R. C. Reid. The koniocellular pathway in primate vision. Annual review of neuroscience, 23(1):127-153, 2000.

[86] J. Hollis and P. M. Allen. Screening for meares-irlen sensitivity in adults: Can assessment methods predict changes in reading speed? Ophthalmic and Physiological Optics, 26(6):566-571, 2006. 
[87] J. Huang, X. Zong, A. Wilkins, B. Jenkins, A. Bozoki, and Y. Cao. fmri evidence that precision ophthalmic tints reduce cortical hyperactivation in migraine. Cephalalgia, 31(8):925-936, 2011.

[88] L. Hugrass, T. Verhellen, E. Morrall-Earney, C. Mallon, and D. P. Crewther. The effects of red surrounds on visual magnocellular and parvocellular cortical processing and perception. Journal of vision, 18(4):8-8, 2018.

[89] S. IMAIZUMI, H. HIBINO, and S. KOYAMA. Effect of colored overlays on reading comfort in people with and without meares-irlen syndrome. International Journal of Affective Engineering, pages IJAE-D, 2016.

[90] A. W. Inhoff and K. Rayner. Parafoveal word processing during eye fixations in reading: Effects of word frequency. Perception \&5 psychophysics, 40(6):431-439, 1986.

[91] H. Irlen. Scotopic sensitivity/irlen syndrome: Hypothesis and explanation of the syndrome. Journal of Behavioral Optometry, 5(62):65-66, 1994.

[92] H. Irlen. Reading by the colors: Overcoming dyslexia and other reading disabilities through the Irlen method. Penguin, 2005.

[93] H. L. Irlen. Method and apparatus of treatment of symptoms of the irlen syndrom, Oct. 9 1990. US Patent 4,961,640.

[94] J. Jayakumar, B. Dreher, and T. R. Vidyasagar. Tracking blue cone signals in the primate brain. Clinical and Experimental Optometry, 96(3):259-266, 2013.

[95] R. Jeanes, A. Busby, J. Martin, E. Lewis, N. Stevenson, D. Pointon, and A. Wilkins. Prolonged use of coloured overlays for classroom reading. British Journal of Psychology, 88(4):541-548, 1997.

[96] H. Jeanny et al. Vision: Images, Signals and Neural Networks: Models of Neural Processing in Visual Perception, volume 19. World Scientific Publishing Company, 2010.

[97] B. Johansson and C. Balkenius. A computational model of pupil dilation. Connection Science, 30(1):5-19, 2018.

[98] E. N. Johnson, M. J. Hawken, and R. Shapley. The spatial transformation of color in the primary visual cortex of the macaque monkey. Nature neuroscience, 4(4):409, 2001.

[99] C. Joselevitch. Human retinal circuitry and physiology. Psychology \& Neuroscience, 1(2):141, 2008.

[100] D. S. Joyce, B. Feigl, G. Kerr, L. Roeder, and A. J. Zele. Melanopsin-mediated pupil function is impaired in parkinson's disease. Scientific reports, 8(1):7796, 2018.

[101] I. Juricevic, L. Land, A. Wilkins, and M. A. Webster. Visual discomfort and natural image statistics. Perception, 39(7):884-899, 2010. 
[102] J. Kaas, M. Huerta, J. Weber, and J. Harting. Patterns of retinal terminations and laminar organization of the lateral geniculate nucleus of primates. Journal of Comparative Neurology, 182(3):517-553, 1978.

[103] W. Kapłonek, M. Sutowska, M. Ungureanu, and K. Çetinkaya. Optical profilometer with confocal chromatic sensor for high-accuracy 3d measurements of the uncirculated and circulated coins. Journal of Mechanical and Energy Engineering, 2, 2018.

[104] C. Kelbsch, T. Strasser, Y. Chen, B. Feigl, P. D. Gamlin, R. Kardon, T. Peters, K. A. Roecklein, S. R. Steinhauer, E. Szabadi, et al. Standards in pupillography. Frontiers in Neurology, 10, 2019.

[105] J. A. Kim, S. J. Oh, E. Choi, Y. T. Kim, and J. E. Sung. A meta-analysis of eye-tracking studies on text processing in children with reading disabilities. Communication Sciences \& Disorders, 23(3):597-608, 2018.

[106] L. J. Klaassen, Z. Sun, M. N. Steijaert, P. Bolte, I. Fahrenfort, T. Sjoerdsma, J. Klooster, Y. Claassen, C. R. Shields, H. M. Ten Eikelder, et al. Synaptic transmission from horizontal cells to cones is impaired by loss of connexin hemichannels. PLoS biology, 9(7):e1001107, 2011.

[107] H. Kolb. Part v: Phototransduction and photoreceptor synaptic pathways. In Webvision: The Organization of the Retina and Visual System [Internet]. University of Utah Health Sciences Center, 2012.

[108] H. Kolb, E. Fernandez, and R. Nelson. Webvision: The organization of the retina and visual system. john moran eye center, university of utah, 2011.

[109] W. J. Krause. Krause's essential human histology for medical students. UniversalPublishers, 2005.

[110] J. Kremers, H. P. Scholl, H. Knau, T. T. Berendschot, T. Usui, and L. T. Sharpe. $\mathrm{L} / \mathrm{m}$ cone ratios in human trichromats assessed by psychophysics, electroretinography, and retinal densitometry. JOSA A, 17(3):517-526, 2000.

[111] I. Kriss and B. J. Evans. The relationship between dyslexia and meares-irlen syndrome. Journal of Research in Reading, 28(3):350-364, 2005.

[112] K. Krstić, A. Šoškić, V. Ković, and K. Holmqvist. All good readers are the same, but every low-skilled reader is different: an eye-tracking study using pisa data. European Journal of Psychology of Education, 33(3):521-541, 2018.

[113] P. B. Kruger, F. J. Rucker, C. Hu, H. Rutman, N. W. Schmidt, and V. Roditis. Accommodation with and without short-wavelength-sensitive cones and chromatic aberration. Vision research, 45(10):1265-1274, 2005.

[114] R. Kruk, K. Sumbler, and D. Willows. Visual processing characteristics of children with meares-irlen syndrome. Ophthalmic and Physiological Optics, 28(1):35-46, 2008. 
[115] A. Ksendzovsky, I. J. Pomeraniec, K. A. Zaghloul, J. J. Provencio, and I. Provencio. Clinical implications of the melanopsin-based non-image-forming visual system. Neurology, 88(13):1282-1290, 2017.

[116] A. M. Labin, S. K. Safuri, E. N. Ribak, and I. Perlman. Müller cells separate between wavelengths to improve day vision with minimal effect upon night vision. Nature communications, 5:4319, 2014.

[117] K. A. Lane. Developing ocular motor and visual perceptual skills: An activity workbook. Slack Incorporated, 2005.

[118] J. L. Lauschke, G. T. Plant, and C. L. Fraser. Visual snow: A thalamocortical dysrhythmia of the visual pathway? Journal of Clinical Neuroscience, 28:123-127, 2016.

[119] C. Lebel, A. Benischek, B. Geeraert, J. Holahan, S. Shaywitz, K. Bakhshi, and B. Shaywitz. Developmental trajectories of white matter structure in children with and without reading impairments. Developmental cognitive neuroscience, 36:100633, 2019.

[120] B. Lee, P. Martin, and A. Valberg. Amplitude and phase of responses of macaque retinal ganglion cells to flickering stimuli. The Journal of Physiology, 414(1):245263, 1989.

[121] C. Lee, W. H. Rohrer, and D. L. Sparks. Population coding of saccadic eye movements by neurons in the superior colliculus. Nature, 332(6162):357, 1988.

[122] J. C. Li, G. P. Sampson, and T. R. Vidyasagar. Interactions between luminance and colour channels in visual search and their relationship to parallel neural channels in vision. Experimental brain research, 176(3):510-518, 2007.

[123] A. Lightstone, T. Lightstone, and A. Wilkins. Both coloured overlays and coloured lenses can improve reading fluency, but their optimal chromaticities differ. Ophthalmic and Physiological Optics, 19(4):279-285, 1999.

[124] M. Livingstone and D. Hubel. Segregation of form, color, movement, and depth: anatomy, physiology, and perception. Science, 240(4853):740-749, 1988.

[125] M. S. Livingstone and D. H. Hubel. Anatomy and physiology of a color system in the primate visual cortex. Journal of Neuroscience, 4(1):309-356, 1984.

[126] M. S. Livingstone, G. D. Rosen, F. W. Drislane, and A. M. Galaburda. Physiological and anatomical evidence for a magnocellular defect in developmental dyslexia. Proceedings of the National Academy of Sciences, 88(18):7943-7947, 1991.

[127] S. J. Loew, N. V. Marsh, and K. Watson. Symptoms of meares-irlen/visual stress syndrome in subjects diagnosed with chronic fatigue syndrome. International journal of clinical and health psychology, 14(2):87-92, 2014.

[128] S. J. Loew and K. Watson. The prevalence of symptoms of scotopic sensitivity/meares-irlen syndrome in subjects diagnosed with adhd: Does misdiagnosis play a significant role? Hrvatska revija za rehabilitacijska istraživanja, 49(Supplement):64-72, 2013. 
[129] C. Lou, X. Duan, I. Altarelli, J. A. Sweeney, F. Ramus, and J. Zhao. White matter network connectivity deficits in developmental dyslexia. Human brain mapping, 40(2):505-516, 2019.

[130] W. J. Lovegrove, R. P. Garzia, and S. B. Nicholson. Experimental evidence for a transient system deficit in specific reading disability. Journal of the American Optometric Association, 1990.

[131] A. K. Ludlow, A. J. Wilkins, and P. Heaton. The effect of coloured overlays on reading ability in children with autism. Journal of Autism and Developmental Disorders, 36(4):507-516, 2006.

[132] M. MacKeben, S. Trauzettel-Klosinski, J. Reinhard, U. Dürrwächter, M. Adler, and G. Klosinski. Eye movement control during single-word reading in dyslexics. Journal of Vision, 4(5):4-4, 2004.

[133] J. B. V. Marques and D. d. Freitas. The delphi method: characterization and potentialities for educational research. Pro-Posições, 29(2):389-415, 2018.

[134] S. Martinez-Conde, S. L. Macknik, X. G. Troncoso, and D. H. Hubel. Microsaccades: a neurophysiological analysis. Trends in neurosciences, 32(9):463-475, 2009.

[135] F. Martos and J. Vila. Differences in eye movements control among dyslexic, retarded and normal readers in the spanish population. Reading and Writing, 2(2):175188, 1990.

[136] A. Mascia, J. Afra, and J. Schoenen. Dopamine and migraine: a review of pharmacological, biochemical, neurophysiological, and therapeutic data. Cephalalgia, 18(4):174-182, 1998.

[137] J. Maunsell, T. A. Nealey, and D. D. DePriest. Magnocellular and parvocellular contributions to responses in the middle temporal visual area $(\mathrm{mt})$ of the macaque monkey. Journal of Neuroscience, 10(10):3323-3334, 1990.

[138] D. L. McCulloch, M. F. Marmor, M. G. Brigell, R. Hamilton, G. E. Holder, R. Tzekov, and M. Bach. Iscev standard for full-field clinical electroretinography (2015 update). Documenta ophthalmologica, 130(1):1-12, 2015.

[139] C. Medland, H. Walter, and J. Margaret Woodhouse. Eye movements and poor reading: does the developmental eye movement test measure cause or effect? Ophthalmic and Physiological Optics, 30(6):740-747, 2010.

[140] C. Meissirel, K. C. Wikler, L. M. Chalupa, and P. Rakic. Early divergence of magnocellular and parvocellular functional subsystems in the embryonic primate visual system. Proceedings of the National Academy of Sciences, 94(11):5900-5905, 1997.

[141] E. Meltzer, P. V. Sguigna, A. Subei, S. Beh, E. Kildebeck, D. Conger, A. Conger, M. Lucero, B. S. Frohman, A. N. Frohman, et al. Retinal architecture and melanopsin-mediated pupillary response characteristics: a putative pathophysiologic signature for the retino-hypothalamic tract in multiple sclerosis. JAMA neurology, 74(5):574-582, 2017. 
[142] A. Mihali, B. van Opheusden, and W. J. Ma. Bayesian microsaccade detection. Journal of vision, 17(1):13-13, 2017.

[143] J. D. S. Miyasaka, R. V. G. Vieira, E. S. Novalo-Goto, E. Montagna, and R. Wajnsztejn. Irlen syndrome: systematic review and level of evidence analysis. Arquivos de neuro-psiquiatria, 77(3):194-207, 2019.

[144] J. Mollon and G. Jordan. On the nature of unique hues. John Dalton's colour vision legacy, pages 381-392, 1997.

[145] L. Monger, A. Wilkins, and P. Allen. Identifying visual stress during a routine eye examination. Journal of optometry, 8(2):140-145, 2015.

[146] P. Moon and D. E. Spencer. On the stiles-crawford effect. JOSA, 34(6):319-329, 1944.

[147] J. J. Nassi and E. M. Callaway. Parallel processing strategies of the primate visual system. Nature reviews neuroscience, 10(5):360, 2009.

[148] J. Neitz, J. Carroll, Y. Yamauchi, M. Neitz, and D. R. Williams. Color perception is mediated by a plastic neural mechanism that is adjustable in adults. Neuron, 35(4):783-792, 2002.

[149] R. Noseda, C. A. Bernstein, R.-R. Nir, A. J. Lee, A. B. Fulton, S. M. Bertisch, A. Hovaguimian, D. M. Cestari, R. Saavedra-Walker, D. Borsook, et al. Migraine photophobia originating in cone-driven retinal pathways. Brain, 139(7):1971-1986, 2016.

[150] J. Otero-Millan, S. L. Macknik, and S. Martinez-Conde. Microsaccades and blinks trigger illusory rotation in the "rotating snakes" illusion. Journal of Neuroscience, 32(17):6043-6051, 2012.

[151] J. Otero-Millan, X. G. Troncoso, S. L. Macknik, I. Serrano-Pedraza, and S. Martinez-Conde. Saccades and microsaccades during visual fixation, exploration, and search: foundations for a common saccadic generator. Journal of vision, $8(14): 21-21,2008$.

[152] C. Palomo-Álvarez and M. C. Puell. Effects of wearing yellow spectacles on visual skills, reading speed, and visual symptoms in children with reading difficulties. Graefe's Archive for Clinical and Experimental Ophthalmology, 251(3):945-951, 2013.

[153] V. F. Pamplona, M. M. Oliveira, and G. V. Baranoski. Photorealistic models for pupil light reflex and iridal pattern deformation. ACM Transactions on Graphics (TOG), 28(4):106, 2009.

[154] M. Parker and D. Henson-Parker. Photon induced visual abnormalities (piva) and dyslexia. In 21st Annual Conference Closing the Gap: Computer Technology in Special Education and Rehabilitation, 2003.

[155] J. M. Pereira, L. Mendieta, P. Y. Sacai, S. R. Salomão, and A. Berezovsky. Estudo normativo do eletrorretinograma de campo total em adultos jovens. Arquivos Brasileiros de Oftalmologia, 2003. 
[156] I. Perlman, H. Kolb, and R. Nelson. S-potentials and horizontal cells. In Webvision: The Organization of the Retina and Visual System [Internet]. University of Utah Health Sciences Center, 2011.

[157] R. Pflug, R. Nelson, S. Huber, and H. Reitsamer. Modulation of horizontal cell function by dopaminergic ligands in mammalian retina. Vision research, 48(12):13831390, 2008.

[158] H. L. Poynter, C. Schor, H. M. Haynes, and J. Hirsch. Oculomotor functions in reading disability. American journal of optometry and physiological optics, 59(2):116$127,1982$.

[159] H. Railo, H. Olkoniemi, E. Eeronheimo, O. Pääkkönen, J. Joutsa, and V. Kaasinen. Dopamine and eye movement control in parkinson's disease: deficits in corollary discharge signals? PeerJ, 6:e6038, 2018.

[160] N. J. RAY, S. Fowler, and J. F. STEIN. Yellow filters can improve magnocellular function: motion sensitivity, convergence, accommodation, and reading. Annals of the New York Academy of Sciences, 1039(1):283-293, 2005.

[161] K. Rayner. Eye movements in reading and information processing: 20 years of research. Psychological bulletin, 124(3):372, 1998.

[162] K. Rayner and R. L. Johnson. by-letter acquired dyslexia is due to the serial encoding of letters. Psychological Science, 16(7):530-534, 2005.

[163] K. Rayner, T. J. Slattery, and N. N. Bélanger. Eye movements, the perceptual span, and reading speed. Psychonomic bulletin \& review, 17(6):834-839, 2010.

[164] M. Razuk, F. Perrin-Fievez, C. L. Gerard, H. Peyre, J. A. Barela, and M. P. Bucci. Effect of colored filters on reading capabilities in dyslexic children. Research in developmental disabilities, 83:1-7, 2018.

[165] D. Regan. Human perception of objects. Sunderland, MA: Sinauer, 2000.

[166] A. Richardson, C. Calvin, C. Clisby, D. Schoenheimer, P. Montgomery, J. Hall, G. Hebb, E. Westwood, J. Talcott, and J. Stein. Fatty acid deficiency signs predict the severity of reading and related difficulties in dyslexic children. Prostaglandins, Leukotrienes and Essential Fatty Acids (PLEFA), 63(1-2):69-74, 2000.

[167] A. J. Richardson, T. Easton, A. M. McDaid, J. A. Hall, P. Montgomery, C. Clisby, and B. K. Puri. Essential fatty acids in dyslexia: theory, evidence and clinical trials. Phospholipid spectrum disorder in psychiatry, pages 225-242, 1999.

[168] P. M. RIDDELL, A. Wilkins, and L. HAINLINE. The effect of colored lenses on the visual evoked response in children with visual stress. Optometry and vision science, 83(5):299-305, 2006.

[169] W. H. Ridder III, E. Borsting, C. Tosha, A. Tong, R. Dougherty, and C. Chase. Ergs and psychophysical thresholds in students with reading discomfort. Optometry and Vision Science, 85(3):180-186, 2008. 
[170] S. J. Ritchie, S. Della Sala, and R. D. McIntosh. Irlen colored overlays do not alleviate reading difficulties. Pediatrics, 128(4):e932-e938, 2011.

[171] D. A. Robinson. Models of the saccadic eye movement control system. Kybernetik, 14(2):71-83, 1973.

[172] G. Robinson, D. Sparkes, T. Roberts, and H. Dunstan. Biochemical anomalies in people with irlen syndrome. In Brugge, Belgium: Eight International Irlen Conference, 2004.

[173] A. Roorda and D. R. Williams. The arrangement of the three cone classes in the living human eye. Nature, 397(6719):520, 1999.

[174] B. Roska and F. Werblin. Rapid global shifts in natural scenes block spiking in specific ganglion cell types. Nature neuroscience, 6(6):600, 2003.

[175] J. Ross, D. Burr, and C. Morrone. Suppression of the magnocellular pathway during saccades. Behavioural brain research, 80(1-2):1-8, 1996.

[176] S. Roy and G. D. Field. Dopaminergic modulation of retinal processing from starlight to sunlight. Journal of pharmacological sciences, 2019.

[177] A. Rukmini, D. Milea, and J. J. Gooley. Chromatic pupillometry methods for assessing photoreceptor health in retinal and optic nerve diseases. Frontiers in neurology, 10, 2019.

[178] P. H. Schiller, N. K. Logothetis, and E. R. Charles. Role of the color-opponent and broad-band channels in vision. Visual neuroscience, 5(4):321-346, 1990.

[179] T. M. Schmidt, M. T. H. Do, D. Dacey, R. Lucas, S. Hattar, and A. Matynia. Melanopsin-positive intrinsically photosensitive retinal ganglion cells: from form to function. Journal of Neuroscience, 31(45):16094-16101, 2011.

[180] L. Scott, H. McWhinnie, L. Taylor, N. Stevenson, P. Irons, E. Lewis, M. Evans, B. Evans, and A. Wilkins. Coloured overlays in schools: orthoptic and optometric findings. Ophthalmic and Physiological Optics, 22(2):156-165, 2002.

[181] A. J. Simmers, L. S. Gray, and A. J. Wilkins. The influence of tinted lenses upon ocular accommodation. Vision Research, 41(9):1229-1238, 2001.

[182] C. Singleton. Visual stress and dyslexia. In The Routledge companion to dyslexia, pages 65-80. Routledge, 2012.

[183] C. Singleton and S. Trotter. Visual stress in adults with and without dyslexia. Journal of Research in Reading, 28(3):365-378, 2005.

[184] B. C. Skottun. The need to differentiate the magnocellular system from the dorsal stream in connection with dyslexia. Brain and cognition, 95:62-66, 2015.

[185] B. C. Skottun and J. R. Skoyles. L-and m-cone ratios and magnocellular sensitivity in reading. International Journal of Neuroscience, 120(4):241-244, 2010. 
[186] I. Smyrnakis, V. Andreadakis, V. Selimis, M. Kalaitzakis, T. Bachourou, G. Kaloutsakis, G. D. Kymionis, S. Smirnakis, and I. M. Aslanides. Radar: A novel fast-screening method for reading difficulties with special focus on dyslexia. PloS one, 12(8):e0182597, 2017.

[187] H. Solan. Transient and sustained processing a dual subsystem theory of reading disability. J Behav Optom, 5(6):149-154, 1994.

[188] H. A. Solan, A. Ficarra, J. R. Brannan, and F. Rucker. Eye movement efficiency in normal and reading disabled elementary school children: effects of varying luminance and wavelength. Journal of the American Optometric Association, 1998.

[189] S. G. Solomon and P. Lennie. The machinery of colour vision. Nature Reviews Neuroscience, 8(4):276, 2007.

[190] G. d. S. Souza, E. M. d. C. B. Lacerda, V. d. A. Silveira, C. d. S. Araújo, and L. C. d. L. Silveira. A visão através dos contrastes. estudos avançados, 27(77):45-60, 2013.

[191] D. Sparkes, G. Robinson, H. Dunstan, and T. Roberts. Plasma cholesterol levels and irlen syndrome: Preliminary study of 10-to 17-yr.-old students. Perceptual and motor skills, 97(3):743-752, 2003.

[192] M. Spitschan, A. S. Bock, J. Ryan, G. Frazzetta, D. H. Brainard, and G. K. Aguirre. The human visual cortex response to melanopsin-directed stimulation is accompanied by a distinct perceptual experience. Proceedings of the National Academy of Sciences, 114(46):12291-12296, 2017.

[193] L. R. Stark, R. S. Lee, P. B. Kruger, F. J. Rucker, and H. Y. Fan. Accommodation to simulations of defocus and chromatic aberration in the presence of chromatic misalignment. Vision Research, 42(12):1485-1498, 2002.

[194] J. Stein. Visual motion sensitivity and reading. Neuropsychologia, 41(13):1785-1793, 2003.

[195] J. Stein. Dyslexia: the role of vision and visual attention. Current developmental disorders reports, 1(4):267-280, 2014.

[196] J. Stein. Reply to: "the relationship between eye movements and reading difficulties", blythe, kirkby \& liversedge. Brain sciences, 8(6):99, 2018.

[197] J. Stein. What is developmental dyslexia? Brain sciences, 8(2):26, 2018.

[198] J. Stein. The current status of the magnocellular theory of developmental dyslexia. Neuropsychologia, 130:66-77, 2019.

[199] C. W. Stephen Ryan, Andrew Schacha and P. W. Andrew Schachat, David Hinton. Chapter 15 - Function and Anatomy of the Mammalian Retina, Retina (Fifth Edition) Volume One, 2013, Páginas 360-400. Elsevier, 2013.

[200] A. Stockman, G. B. Henning, S. Anwar, R. Starba, and A. T. Rider. Delayed coneopponent signals in the luminance pathway. Journal of vision, 18(2):6-6, 2018. 
[201] A. Stockman, D. I. MacLeod, and D. D. DePriest. The temporal properties of the human short-wave photoreceptors and their associated pathways. Vision research, 31(2):189-208, 1991.

[202] C. Stromeyer III, P. Gowdy, A. Chaparro, S. Kladakis, J. Willen, and R. Kronauer. Colour adaptation modifies the temporal properties of the long-and middle-wave cone signals in the human luminance mechanism. The Journal of Physiology, 526(Pt 1):177, 2000 .

[203] C. M. Suttle, J. Barbur, and M. L. Conway. Coloured overlays and precision-tinted lenses: poor repeatability in a sample of adults and children diagnosed with visual stress. Ophthalmic And Physiological Optics, 37(4):542-548, 2017.

[204] K. Taylor, C. Higgins, C. Calvin, J. Hall, T. Easton, A. McDaid, and A. Richardson. Dyslexia in adults is associated with clinical signs of fatty acid deficiency. Prostaglandins, Leukotrienes and Essential Fatty Acids (PLEFA), 63(1-2):75-78, 2000.

[205] J. Thomson. The contribution of the magnocellular visual pathway to the process of visual word recognition. 2007.

[206] S. Tosta, H. Irlen, J. Lewine, and J. Annibali. Precision-tinted colored filters: A successful intervention for medically resistant headaches and migraines after brain injury.

[207] X. G. Troncoso, S. L. Macknik, J. Otero-Millan, and S. Martinez-Conde. Microsaccades drive illusory motion in the enigma illusion. Proceedings of the National Academy of Sciences, 105(41):16033-16038, 2008.

[208] S.-i. Tsujimura and Y. Tokuda. Delayed response of human melanopsin retinal ganglion cells on the pupillary light reflex. Ophthalmic and Physiological Optics, 31(5):469-479, 2011.

[209] L. G. Ungerleider. Two cortical visual systems. Analysis of visual behavior, pages 549-586, 1982.

[210] L. G. Ungerleider and J. V. Haxby. 'what'and 'where'in the human brain. Current opinion in neurobiology, 4(2):157-165, 1994.

[211] C. Urtubia Vicario. Fisiología de la retina i. el mensaje visual en la primera sinapsis. 2004.

[212] A. Vagge, M. Cavanna, C. E. Traverso, and M. Iester. Evaluation of ocular movements in patients with dyslexia. Annals of dyslexia, 65(1):24-32, 2015.

[213] J. Veszeli and A. J. Shepherd. A comparison of the effects of the colour and size of coloured overlays on young children's reading. Vision research, 156:73-83, 2019.

[214] T. R. Vidyasagar. Attentional gating in primary visual cortex: A physiological basis for dyslexia. Perception, 34(8):903-911, 2005.

[215] A. Wilkins. A system for precision ophthalmic tinting: A manual for the intuitive colorimeter and trial lenses. Cerium Visual Technologies, Tenterden, Kent, UK, 1993. 
[216] A. Wilkins. Reading through colour. Chichester (EG): Wiley, 2003.

[217] A. Wilkins. Origins of visual stress. Visual Aspects of Dyslexia, Ed. Stein J and Kapoula Z., Oxford University Press, 4:63-77, 2012.

[218] A. Wilkins. A theory of visual stress and its application to the use of coloured filters for reading. Progress in Colour Studies: Cognition, language and beyond, pages 319-339, 2018.

[219] A. Wilkins, B. Evans, J. Brown, A. Busby, A. Wingfield, R. Jeanes, and J. Bald. Double-masked placebo-controlled trial of precision spectral filters in children who use coloured overlays. Ophthalmic and Physiological Optics, 14(4):365-370, 1994.

[220] A. Wilkins, J. Huang, and Y. Cao. Visual stress theory and its application to reading and reading tests. Journal of Research in Reading, 27(2):152-162, 2004.

[221] A. Wilkins, J. Huang, and Y. Cao. Prevention of visual stress and migraine with precision spectral filters. Drug development research, 68(7):469-475, 2007.

[222] A. Wilkins, E. Lewis, F. Smith, E. Rowland, and W. Tweedie. Coloured overlays and their benefit for reading. Journal of research in reading, 24(1):41-64, 2001.

[223] A. Wilkins and I. Nimmo-Smith. On the reduction of eye-strain when reading. Ophthalmic and Physiological Optics, 4(1):53-59, 1984.

[224] A. Wilkins, R. Patel, P. Adjamian, and B. Evans. Tinted spectacles and visually sensitive migraine. Cephalalgia, 22(9):711-719, 2002.

[225] A. J. Wilkins. Risk of bias in assessing risk of bias. Ophthalmic \& physiological optics: the journal of the British College of Ophthalmic Opticians (Optometrists), 37(1):107, 2017.

[226] A. J. Wilkins, A. Baker, D. Amin, S. Smith, J. Bradford, Z. Zaiwalla, F. M. Besag, C. D. Binnie, and D. Fish. Treatment of photosensitive epilepsy using coloured glasses. Seizure, 8(8):444-449, 1999.

[227] A. J. Wilkins and B. J. Evans. Visual stress, its treatment with spectral filters, and its relationship to visually induced motion sickness. Applied ergonomics, 41(4):509$515,2010$.

[228] A. J. Wilkins, R. Jeanes, P. Pumfrey, and M. Laskier. Rate of reading test@: its reliability, and its validity in the assessment of the effects of coloured overlays. Ophthalmic and Physiological Optics, 16(6):491-497, 1996.

[229] A. J. Wilkins and M. Nimmo-Smith. The clarity and comfort of printed text. Ergonomics, 30(12):1705-1720, 1987.

[230] M. C. Williams and W. Lovegrove. Sensory and perceptual processing in reading disability. In Advances in psychology, volume 86, pages 263-302. Elsevier, 1992.

[231] P. Witkovsky. Dopamine and retinal function. Documenta ophthalmologica, 108(1):17-39, 2004. 
[232] C. Wotschack. Eye movements in reading strategies: How reading strategies modulate effects of distributed processing and oculomotor control, volume 1. Universitätsverlag Potsdam, 2009.

[233] B. N. Wright, A. J. Wilkins, and Y. Zoukos. Spectral filters can improve reading and visual search in patients with multiple sclerosis. Journal of Neurology, 254(12):1729$1735,2007$.

[234] J. Wu, H. Xiao, H. Sun, L. Zou, and L.-Q. Zhu. Role of dopamine receptors in adhd: a systematic meta-analysis. Molecular neurobiology, 45(3):605-620, 2012.

[235] M. Yamakawa, S.-i. Tsujimura, and K. Okajima. A quantitative analysis of the contribution of melanopsin to brightness perception. Scientific reports, 9(1):7568, 2019.

[236] K.-F. Yang, S.-B. Gao, C.-F. Guo, C.-Y. Li, and Y.-J. Li. Boundary detection using double-opponency and spatial sparseness constraint. IEEE Transactions on Image Processing, 24(8):2565-2578, 2015.

[237] L. R. Young and L. Stark. Variable feedback experiments testing a sampled data model for eye tracking movements. IEEE Transactions on Human Factors in Electronics, (1):38-51, 1963.

[238] S. Zeki and S. Shipp. The functional logic of cortical connections. Nature, 335(6188):311, 1988.

[239] A. J. Zele, P. Adhikari, D. Cao, and B. Feigl. Melanopsin driven enhancement of cone-mediated visual processing. Vision research, 160:72-81, 2019.

[240] A. J. Zele, B. Feigl, P. Adhikari, M. L. Maynard, and D. Cao. Melanopsin photoreception contributes to human visual detection, temporal and colour processing. Scientific reports, 8(1):3842, 2018.

[241] A.-J. Zhang, R. Jacoby, and S. M. Wu. Light-and dopamine-regulated receptive field plasticity in primate horizontal cells. Journal of Comparative Neurology, 519(11):2125-2134, 2011.

[242] D.-Q. Zhang, K. Y. Wong, P. J. Sollars, D. M. Berson, G. E. Pickard, and D. G. McMahon. Intraretinal signaling by ganglion cell photoreceptors to dopaminergic amacrine neurons. Proceedings of the National Academy of Sciences, 105(37):1418114186, 2008.

[243] X. Zhao, B. K. Stafford, A. L. Godin, W. M. King, and K. Y. Wong. Photoresponse diversity among the five types of intrinsically photosensitive retinal ganglion cells. The Journal of physiology, 592(7):1619-1636, 2014.

[244] Z. Zhu, Q. Wang, W. Zou, and F. Zhang. Motion control on bionic eyes: A comprehensive review. arXiv preprint arXiv:1901.01494, 2019. 